\title{
Caesarism, Fujimori and the Transformation of Peru into a Neoliberal Order
}

\author{
By Peter McKenzie Atack \\ B.A. M.A. \\ A thesis submitted to \\ the Faculty of Graduate Studies and Research \\ in partial fulfillment of \\ the requirements for the degree of \\ Doctorate of Philosophy
Department of Political Science
Carleton University
Ottawa, Ontario
Canada

@Peter McKenzie Atack 2006 


$\begin{array}{ll}\begin{array}{l}\text { Library and } \\ \text { Archives Canada }\end{array} & \begin{array}{l}\text { Bibliothèque et } \\ \text { Archives Canada }\end{array} \\ \begin{array}{l}\text { Published Heritage } \\ \text { Branch }\end{array} & \begin{array}{l}\text { Direction du } \\ \text { Patrimoine de l'édition }\end{array} \\ \begin{array}{l}\text { 395 Wellington Street } \\ \text { Ottawa ON K1A ON4 }\end{array} & \begin{array}{l}\text { 395, rue Wellington } \\ \text { Ottawa ON K1A ON4 } \\ \text { Canada }\end{array}\end{array}$

Your file Votre référence ISBN: 978-0-494-18207-9 Our file Notre référence ISBN: 978-0-494-18207-9

NOTICE:

The author has granted a nonexclusive license allowing Library and Archives Canada to reproduce, publish, archive, preserve, conserve, communicate to the public by telecommunication or on the Internet, loan, distribute and sell theses worldwide, for commercial or noncommercial purposes, in microform, paper, electronic and/or any other formats.

The author retains copyright ownership and moral rights in this thesis. Neither the thesis nor substantial extracts from it may be printed or otherwise reproduced without the author's permission.
AVIS:

L'auteur a accordé une licence non exclusive permettant à la Bibliothèque et Archives Canada de reproduire, publier, archiver, sauvegarder, conserver, transmettre au public par télécommunication ou par l'Internet, prêter, distribuer et vendre des thèses partout dans le monde, à des fins commerciales ou autres, sur support microforme, papier, électronique et/ou autres formats.

L'auteur conserve la propriété du droit d'auteur et des droits moraux qui protège cette thèse. $\mathrm{Ni}$ la thèse ni des extraits substantiels de celle-ci ne doivent être imprimés ou autrement reproduits sans son autorisation.
In compliance with the Canadian

Privacy Act some supporting forms may have been removed from this thesis.

While these forms may be included in the document page count, their removal does not represent any loss of content from the thesis.
Conformément à la loi canadienne sur la protection de la vie privée, quelques formulaires secondaires ont été enlevés de cette thèse.

Bien que ces formulaires aient inclus dans la pagination, il n'y aura aucun contenu manquant.

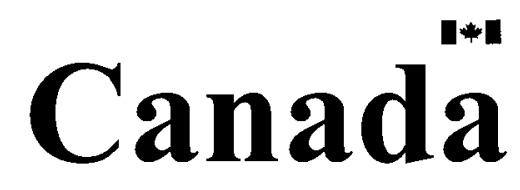




\section{Abstract: Caesarism, Fujimori and the Transformation of Peru into a Neoliberal Social Formation.}

During the government of President Alberto Fujimori (1990-2000), Peru undertook a radical shift in its economic policies from state-led industrialization toward neoliberalism. The research question of this thesis is: what was the effect of imposing neoliberal economic policies on Peru? How was it that a political outsider like President Fujimori succeeded in imposing structural adjustment when previous attempts had failed?

This thesis utilizes Gramsci's theory of Caesarism to understand how an outsider like Fujimori was able to dismantle the previous order based on stateled industrialization. The campaign of Sendero Luminoso had created a security crisis that undermined the political elite and decimated grass roots organizations. Peru had imploded in hyperinflation, corruption and economic disaster. This led to a crisis in representation that destroyed support for all of the political parties and disarticulated civil society organizations like unions. Fujimori was thus able to dissolve the old while imposing new neoliberal relations of production. These relations were articulated through labour code reforms that made labour subject to market forces by making unions ineffective.

Instead of looking for the genesis of a transformation in relations of production or structures of the state or the ideologies that legitimate them, this thesis explores and utilizes the theory of structural affinity to explore the interdependence of all three. Orders are not the outcome of dialectical progress or economic effectiveness or moral superiority, instead they are only a reflection 
of a moment of stability when the state reproduces its characteristic social relations of production and both are legitimated by an ideology. Therefore this thesis examines how neoliberal changes to the state reinforce changes in the economy and how these changes then prove to be politically useful by dismantling sites of resistance. Neoliberal theory also plays a role by providing arguments that invert the moral case for collective action, arguments that are articulated and used by neoliberal technocrats as they impose market reforms. Transformation involves more than slight changes in government policies, it requires an entirely new ethos for state-society relations and state that reproduces the new neoliberal relations of production. 


\section{Table of Contents}

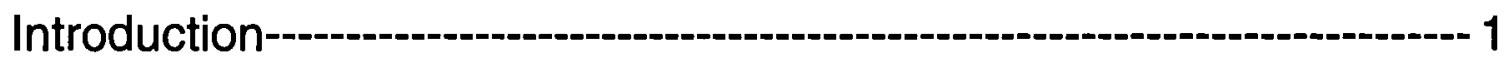

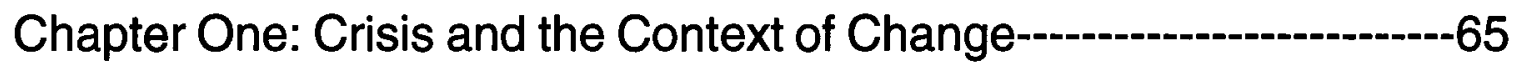

Chapter Two: The Political Consequences of Neoliberal

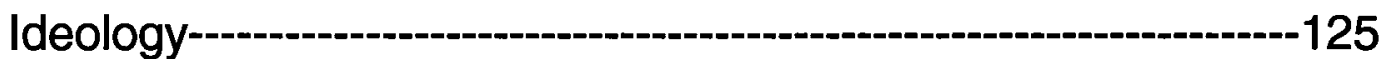

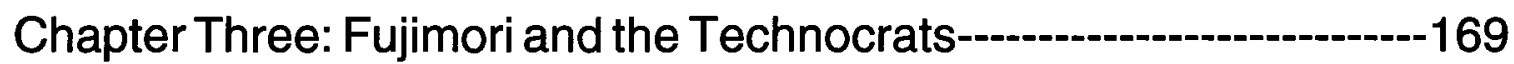

Chapter Four: Hegemony and Enforcement------------------------------215

Chapter Five: Washington Consensus: A New Ideology,

A New Global Economic Order and a New State-----------------245

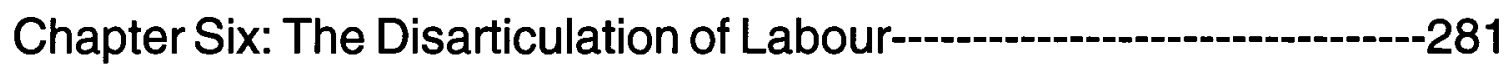

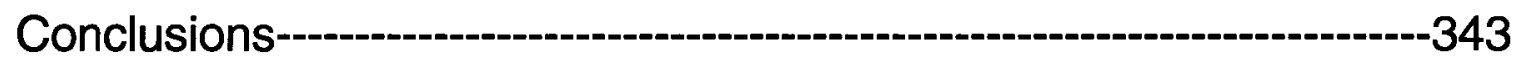

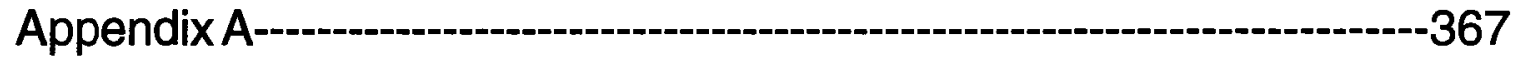

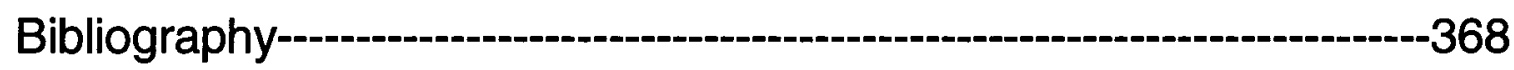




\section{Introduction}

From the 1980's onwards, nations adopted structural adjustment programs to reform their economies in the hope that they could resolve their debt crises and escape hyperinflation and economic collapse. These reforms required more than a simple change in government policy. They required a fundamental alteration to the institutions of the state, in the relationship between state and society to support a new dominant form of the social relations of production, plus a new ideology to legitimate these new relations. What was involved in structural adjustment, then, was the creation of a new order.

This thesis utilizes the term order to denote the overarching combination of political, economic and ideological spheres that together define a society. An order is organized through the articulation of ideas that legitimate a specific kind of state structure whose institutions reproduce certain relations of production in the economy. State institutions reproduce both the ideology that legitimates and validates this order as well as it enforces and regulates its characteristic relations of production. Each order's economy produces the resources that are utilized to reproduce its characteristic form of the state and the institutions in civil society that articulate the ideology that validates the specific class relations characteristic of this order. Every order can be characterized and described by its own set of state institutions, dominant mode of the social relations of production and ideology. An order is defined by its particular combination between these areas or spheres. Thus, change to one area of an order will then result in 
changes to the other areas.

However, while the changes involved under structural adjustment did involve transforming state institutions, the economy and ideology, this was not the epoch shattering transition from feudalism to capitalism. Instead we are examining a switch between types of capitalism, between an order that was organized around state-led industrialization and the capitalism of neoliberalism. The question is: how much was changed in the transformation from one order to another?

The case selected for this study was the structural adjustment undertaken during the government of President Alberto Fujimori (1990-2000). Fujimori was a political outsider who had neither previous political experience nor the support of pre-existing political parties nor a system of beliefs nor even any clear program for reform. At this conjuncture Peru was faced by a triple crisis: a security crisis caused by Sendero Luminoso (a brutal and destructive guerrilla movement), and an economic crisis marked by both hyperinflation and collapse, which in turn sparked a political crisis, specifically a crisis of representation (see Chapter One for details). The previous President, Alan García (1985-1990), had attempted to reflate the economy by limiting payments to international creditors and boosting domestic demand. These measures resulted in hyperinflation and an economic collapse which exacerbated the crisis caused by Sendero. Alberto Fujimori was elected on a vague platform that ruled out shock policies to end hyperinflation, shock policies he nonetheless implemented once he took office. President Fujimori not only restructured the economy. He also restructured the 
political system after the autogolpe or self coup of April 5, 1992, when he suspended the Peruvian Constitution of 1979 , dissolved Congress and the judiciary. From the autogolpe until the election of 2000, Fujimori ruled without any effective checks on his power with an increasingly corrupt and authoritarian government.

The fundamental research question for this thesis is: what were the effects of the changes implemented by Fujimori on Peru's order? Fujimori radically transformed Peru's state structures, economic policies, and the underlying ethos that legitimated them both. The scope of these changes indicated that economic reforms involved more than a change in economic policies. Economic reforms involved a fundamental shift in social, economic and political relationships that together entailed a transformation of the entire order.

One of the problems posed by this case is how was it possible for a political outsider like Fujimori to impose such radical changes? Since Fujimori had no connections to pre-existing political parties or politically active organisations like labour unions, he could not use their political resources to develop a consensus on the need for change. But instead of being paralysed by his lack of connections, Fujimori used his autonomy to dismantle pre-existing institutions.

The theoretical construct utilized by this thesis to understand the phenomena of Fujimori is Gramsci's theory of Caesarism. Gramsci argues that the appearance of a "man of destiny" is a reflection of a profound crisis of hegemony in a society wherein neither the previous dominant class nor a new 
class has the ability to claim the legitimate right to rule. ${ }^{1}$ According to Gramsci, a Caesarist dictator appears from outside pre-existing orders to resolve a crisis of domination and impose a new order that reflects the needs of a rising bourgeois class fraction, a new dominant class. Gramsci's work points towards an underlying crisis of hegemony of an historic bloc as being the cause of a Caesarist dictatorship.

However, the Peruvian case points to an interesting problem with this model. Instead of an impasse between a declining dominant class and an insurgent class, the previous order had imploded (see Chapter One). This was not a case where a new bourgeois fraction whose power was based on a different (albeit still capitalist) form of the relations of production was barred from expanding its control and penetration of the economy by a state dedicated to reproducing the previous mode of production.

In this case, an underlying crisis of accumulation caused by the failure of the economic model had led to an economic collapse which, in turn, led to a crisis of representation and the political bankruptcy of all previous political actors. In this case, Caesarism was a solution to the abject failure of the previous order and not a method of removing a blockage in the dialectical development of productive forces.

But if there was not a dialectical progression to the transformation of Peru

1

Antonio Gramsci, Selections from the Prison Notebooks, ed. Quinton Hoare and Geoffrey Nowell Smith (New York: International Publishers, 1971), 211. 
from the previous order characterized by state-led industrialization to neoliberalism, how do we account for this transformation? If changes in the relations of production did not drive the transformation, then what did? This thesis uses a theory of structural affinity to understand how ideology, the economy and the state interacted in the process of transformation.

The roots of structural affinity began with Weber's concept of elective affinity. Elective affinity refers to the process whereby certain religious ideals were elected or unconsciously selected over time to become the underlying geist or ethos underlying capitalism. ${ }^{2}$ Through his understanding of how the ideals of Protestantism supported the rise of capitalism, Weber pointed out that what had prevailed were mutually supportive relationships between the economy, the state and ideas. But in the case of this transformation, ideas were not slowly selected over time to reflect the values of a new dominant class. Instead a crisis of accumulation caused a crisis in representation which reflected a hegemonic crisis resolved through a transformation of the state legitimated by a new ideology which then changed relations of production.

Note that change does not always begin in one area with ideas or underlying economic forces or political structures. A challenge in one area does

2

H. H. Gerth and C. Wright Mills, "The Sociology of Ideas and Interests" in From Max Weber (New York: Oxford University Press, 1958), 63. This concept of elective affinity derives from Weber's understanding of how Protestant worldly asceticism created both the disciplined workforce who saw work as a vocation, and the entrepreneurial early capitalists who were driven to accumulate capital as a worthy act in its own right. See Max Weber, The Protestant Ethic and the Spirit of Capitalism (New York: Charles Scribner's and Sons, 1958). 
not necessarily result in the transformation of the content of the other poles. An ideological challenge by neoliberalism to Keynesianism does not necessarily result in the transformation of the state and economy. Any attempt at new relations of production does not necessarily spark a political revolution, and crises in the state do not always result in the transformation of the order. What transformations required was a mutually supportive relationship between each area, wherein each reproduced the others. Thus what was important to understand was how changes in each area could support changes to the other areas.

This introduction will first explore the central concepts of an order and Caesarism in order to locate this study within a broader theoretical tradition. Next, this introduction will explain how these concepts in turn make a contribution to the field of political science. By offering a structural explanation for events through the lens of Caesarism, this thesis offers a more useful understanding of the phenomenon of neo-populism and the rise of Alberto Fujimori than previous accounts. By exposing the connection between the political moment and our understanding of the trajectory of Fujimori's career shifts from explanations rooted in the peculiarities of the Peruvian case, to understanding how the shift to an authoritarian solutions was rooted within a transformation to the underlying order. Then a methodological section will show how research was conducted for the substantive chapters of this study. Finally the structure of the argument of the subsequent chapters will be discussed to explain how the questions raised by this study were answered in the body of the 
text. But before the search can begin, certain ideas must be defined and certain parameters set, in order to reveal the theoretical context for this study.

\section{Theoretical Context and Contributions}

The set of theories that proved to be the most insightful and heuristically useful in understanding how Peru was transformed were Marx and Gramsci's theories of Bonapartism and Caesarism in combination with a theory of structural affinity. This section will explore some of the theoretical basis for this work and how this work further develops these ideas.

This thesis also offers a contribution to Marx and Gramsci's work on crises of hegemony and representation by exploring more fully how a crisis in accumulation resulted in an hegemonic crisis, which in turn generated a crisis in representation that defenestrated ${ }^{3}$ all established Peruvian political parties. Marx's work on Louis Bonaparte examined the structural causes for the rise of a political outsider who was first elected president and then overthrew the legislature and constitution and imposed the Second Empire. The trajectory of this case was strikingly similar to that of Alberto Fujimori. ${ }^{4}$ In the "Eighteenth

Defenestration refers to the act of assassinating someone by throwing them out the window. This is an apt metaphor for the fates of Peru's political parties who, before Fujimori, were competing to win elections, and then, by the next election garnered no appreciable support or respect. Their plunge in support can thus be likened to being thrown out the window and plunged into the political abyss.

4

Maxwell A. Cameron in "The Eighteenth Brumaire of Alberto Fujimori" has acknowledged the applicability of Marx's work to the situation in Peru, especially vis-a-vis the autogolpe of April $5^{\text {th }} 1992$. However while Cameron's work notes 
Brumaire of Louis Napoleon," Marx argued that when the political parties in France failed to establish order and govern in the name of the bourgeoisie, the bourgeoisie abandoned power to Napoleon III who imposed a political solution to the crisis from outside. ${ }^{5}$ The underlying cause of this crisis was a crisis of representation wherein bourgeois political parties failed to capture the support of the peasantry and hence failed to secure legitimacy and stability (see Chapter One for more details).

This thesis utilized Marx's analysis in the Peruvian case, partially because of the parallels between the cases of Louis Napoleon and Alberto Fujimori, but also, too, because these parallels then guided our examination of the Peruvian case. For example, Marx noted that the root of Napoleon III's support among the French peasantry was only a symbolic appeal to their past glories rather than serving their material interests. Likewise, one of Fujimori's basic methods of generating support was to appeal on a symbolic level (rather than to their material class interests) to isolated rural Peruvians by wearing their traditional clothing at rallies, by not being another criollo or ethnically European leader, an appeal symbolized by his slogan that he promised to be "a president like them." When the dominant criollo elites failed to govern effectively in an ethnically

the historic parallels between Napoleon III, Cromwell, and Fujimori, he fails to develop the theoretical insights of Marx in understanding this crisis. See Maxwell A. Cameron, "The Eighteenth Brumaire of Alberto Fujimori" in The Peruvian Labyrinth: Polity, Society, Economy, ed. Maxwell A. Cameron and Philip Mauceri (University Park: Pennsylvania State University Press, 1997).

${ }^{5}$ Marx, 304-309. 
divided nation like Peru, Fujimori's symbolic recognition of indigenous customs created a bond with these communities.

While Marx 's work offers useful insights into these cases and pointed out their structural roots in a crisis of representation, Gramsci provides an analysis of the cause of some crises of representation in what he described as a crisis of hegemony. These crises were caused by a failed undertaking by the historic bloc or the coalition of elite classes. This bloc fostered consent to its rule through ideology, through inculcating its class values into the common sense of the masses. When this elite failed, belief faltered, consent crumbled and the hegemonic crisis was resolved by a Caesarist dictator from outside who imposed a new social and economic order (see Chapter One).

Gramsci also points to the role of what he described as cosmopolitan intellectuals in spreading new arrangements to the periphery. These intellectuals, or in the Peruvian case, neoliberal technocrats, were organically linked to classes in the centre rather than to their home countries. These technocrats used their connections to the IFIs (International Financial Institutions) to reorganize the state on neoliberal lines by reducing its responsibilities, transferring resources to the private sector and transforming labour relations in ways that ended state-led industrialization.

While the theory of hegemonic crisis explains how it was possible for Peru to be transformed, the question remains: why was it that neoliberalism became the template for a new order? Neoliberalism was imposed through pressure by the IFIs on Peru (see Chapter Four). But neoliberalism as an 
international system has neither been the most effective at promoting development nor has it led to the fulfilment of capitalism's potential for ever increasing productivity. The imposition of global neoliberalism has not led to the magical transformation of the periphery into a replica of the developed world. Yet these policies have persisted in the form of the Washington Consensus.

If neoliberalism has not sparked development for the south, how does it survive? Structural affinity provides a heuristically useful means of understanding how orders can become stabilized. Structural affinity indicates that transformations do not originate only within the realm of ideas, or by political action or through changes in the economy. Instead there is an interplay between ideas, the economy and politics that together drive change.

Structural affinity also shifts our emphasis for inquiry from assuming that there is a dialectical path towards better orders to arrangements that are merely stable and self reinforcing. Stability for an order is the result of a series of affinities between an ideology, a particular formation of the state and a dominant social relation of production. Note that stability does not require that the ideology promote the universal "truth" of an economic system namely one that is that is the most productive or dynamic, or a state that promotes justice or equality. Stability only requires that each support the other. Challenges to the status quo can then come from any one of the three poles, but fundamental change requires transformation of all three.

The concept of an order is utilized to describe a triple ensemble of a regime of accumulation supported by a specific state structure that also 
reinforces a dominant type of social relation of production, which in turn is articulated by an ideology that legitimates and validates both that state structure and the dominant form of social relations of production. Thus a change in orders involves a change in ideology, the state and the economy. Moving to neoliberalism in Peru involved the transformation of state structures to reflect and change relations of production which were reflected by changes in normative values expressed by neoliberalism as an ideology.

What is especially fruitful about utilizing the concept of structural affinity to understand transformations is that it focussed attention on how each part of the order reinforced changes to the others. Thus neoliberalism as an ideology could be examined to discover how its principles could be used to justify the reduction of the role of the state to the extent that subaltern classes would no longer look to the state for redress. To understand how opposition to the new order by labour unions was undermined, neoliberal arguments against labour rights can be explored to understand how they were weakened. Neoliberal policy reforms not only restructured the state, they also justified a shift in relations of production in the economy. Neoliberal reforms to the economy then supported changes to the state, while they also reflected the new ideology. Thus structural affinity focusses attention on the crucial interrelationships between these arenas.

But before beginning the examination of this particular process of transformation, the kind of order that existed before Fujimori's reforms - state-led industrialization (SLI) - should be briefly sketched. SLI is usually used only as a description of a set of government economic policies that utilized regulation, 
subsides to the private sector and strategic investment in state-owned enterprises to kick start development. However this set of policies was more than a simple development project for it defined a series of relationships in this order. SLI offered the template for relations of production in the formal economy. It also defined this order's trade and development strategy. The hopes and dreams offered by SLI were the basis of the normative values that legitimated the overall political, economic and moral order. Because of the centrality of this development project, state-led industrialization is the most accurate label for this order in its entirety.

SLI was also the basis of the elite alliance or, as Gramsci described it, a historic bloc that dominated the previous order. The historic bloc for this order was composed of the national bourgeoisie, the officer corp and the upper echelon of the civil service. This order's historic bloc arranged its division of spoils through the policies driven by SLI. The national bourgeoisie sought access to subsidies. The higher levels of the officer corp sought post-retirement appointments to the state-owned sector. There was also a state managerial elite for these state-owned enterprises. ${ }^{6}$ Investment was led by a large state-owned sector, while private capital was guided towards strategic areas by access to state-subsidized credit and exchange rates. The exchange rate and other subsidies for the private sector were some of the means by which the national

6

Carol Wise, "State Policy and Social Conflict in Peru." The Peruvian Labyrinth: Polity, Society, Economy Maxwell A. Cameron and Philip Mauceri eds. (University Park: Pennsylvania State University Press, 1997) 73. 
bourgeoisie could extract surplus value via the state. State-owned enterprises also offered possibilities through their absorption of losses and provision of subsidized inputs.

In addition, state-led industrialization as a development project legitimated the rule of the historic bloc to subaltern classes. SLI was supposed to lead to the promised land of development, a journey led and guided by members of the historic bloc. Thus state-led industrialization as an ideological project for the future was the cement around which these elites allied, no matter how fleetingly, no matter how unsuccessfully.

The ideas of SLI also set the tone for labour relations in the formal sector for this order. As Alain Lipietz argued, under some versions of peripheral Fordism, consumption was artificially focussed in a small professional and bureaucratic class and the industrial working class by state intervention through regulation. For these workers, labour relations were governed by norms that included life long job tenure, wage pacts and strong unions. In Peru labour rights and wage increases were imposed by state intervention either to curry favour with select unions or to soothe fractious labour disputes that threatened political stability (see Chapter Six for details). Because labour disputes were so politicized, there was no linkage between increased productivity and profits and increased wages. This version of peripheral Fordism differed from the regime of accumulation found in the centre because it lacked the connection between 
increases in productivity and profits and consumption. ${ }^{7}$ Peripheral Fordism lacked both Fordism's mass consumer norms and its social labour processes;, in other words, production was not geared towards consumption for all and the social labour practices found under Fordism were not replicated in the periphery.

The Peruvian version of state-led industrialization utilized the strategy of ISI with its branch plant assembly lines geared towards domestic consumption rather than the bloody Taylorization of low wage, low skills assembly line characteristic of the export oriented development of the NICs. As Alain Lipietz described it, peripheral Fordism was "explicitly predicated upon the assumption that mass consumption outlets can be increased either by winning share of the world market or by stimulating home demand." ${ }^{\prime \prime}$ Reactivation under García was simply an explicit attempt to drive development through increased domestic consumption.

But the state-led industrial sector only represented a small fraction of Peru's economy and society, with the rural and informal sectors existing outside the formal sector's labour processes and rewards. In 1990, one third of the population still lived in rural areas. ${ }^{10}$ Even in Lima, half the population lived in the pueblos jovenes, (new town) shantytowns that were formed through land

${ }^{7}$ Lipietz, 79.

${ }^{8}$ Lipietz, 62.

${ }^{9}$ See Lipietz, ff 15, 208.

10

Zelia Roelofse-Campell, "The Fight against Poverty in Peru," in Peru Beyond the Reforms (Lima: Prom Peru, 1996), 149. 
invasions, lacked formal legal status and state-built amenities like sewer, water, electricity, pavement and other services. ${ }^{11}$ By $1996,60 \%$ of the population worked in the informal sector outside of the protection of the labour code. ${ }^{12}$ The percentage of wage workers in Lima who were unionized had declined precipitously, falling from $12.4 \%$ in 1970 to $4.8 \%$ in 1990 then down to $2.4 \%$ in $1995 .{ }^{13}$ But if only a small proportion of the population worked within the formal sector, why was the industrial sector important and indeed dominant?

The importance of this sector becomes clearer once dominance is defined. Which of the relations of production are dominant within a particular order at a particular time can be determined by establishing which mode is reproduced by the formal regulations and institutions of the state and whose values set the relationship between subaltern groups and the political system. Thus, under state-led industrialization, the Peruvian state protected and enforced workers wages and life long job tenure for workers in the formal sector through

11

Jo Marie Burt, "Shining Path and the 'Decisive Battle' in Lima's Barriadas: The Case of Villa El Salvador," in Shining and Other Paths: War and Society in Peru, 1980-1995, ed. Steve J. Stern (Durham and London: Duke University Press, 1998), 271. Each of the pueblos jovenes worked to develop its municipal infrastructure through pressure on the state, getting roads, water sewer, and garbage collection established. But no matter how well established each of these neighbourhoods became, because they were outside the formal state system, their residents lived outside the state.

${ }^{12}$ Roelofse-Campbell, 164.

13

John Sheahan, Searching For a Better Society. The Peruvian Economy from 1950 (University Park, Pennsylvania: The Pennsylvania University Press, 1999), 89. 
the provisions of the labour code (see Chapter Six). The relationship between political parties and subaltern groups was also defined within the institutions and values of this version of state-led industrialization. The major vector through which political parties had established a broad support base in the emerging working class was through their own colonized labour unions. Thus the vector for mass membership and mass support for political parties was organized through labour unions.

State-led industrialization not only shaped relations of production through setting the labour code, it also helped define the topics around which political struggle took place. Labour relations were always intensely political, with the state intervening on the side of unions to maintain social peace and create a base of support for the government within an emerging industrial class. As James L. Payne suggested in 1965, this style of labour relations in Peru was "political bargaining" wherein unions had historically used threats of political instability to force the president to intervene on their behalf. ${ }^{14}$

The state also tried to integrate the rural sector into the political system through state-funded and controlled cooperatives through the agency SINAMOS and agricultural extension programs. These institutions offered resources for development and also linked rural areas into the national political economy. These programs also formed the political base for the Izquierda Unida (the

14

James L. Payne, Labour and Politics in Peru (New Haven: Yale University Press, 1965), 11. 
United Left coalition) with party members working for rural development.

However, while these institutions provided an important vector for contact and control, its relations of production were not dominant. Its values of reciprocal exchange and its markets based on clientalistic relations did not set the tone for the state. Instead the norms of state-led industrialization defined the legal code and the terms of class struggle.

In the pueblos jovenes political connections were maintained through clientelism and grassroots organising to obtain resources from the state (see Chapter One). But as the state lost the capacity to respond to demands, political parties also lost their ability to deliver services to members. Even though neither the rural nor informal sectors received the benefits of state-led industrialization, their political connections to the state were still based on redistribution. As the state lost its capacity to deliver services, even this minimal integration into the system disappeared.

While state-led industrialization dominated, it did not have to transmute all labour into its relations of production. As Robert Cox noted, other modes of the social relations of production will coexist with a dominant mode, but these other modes will be subordinated to its needs. ${ }^{15}$ For example, agriculture in the Sierra provided cheap produce for informal markets, and participation by members of the family as pedlars in turn provided the extra income which allowed those in

15

Robert Cox, Power, Production and World Order: Social Forces in the Making of History (New York: Columbia University Press, 1987), 356. 
the formal sector to survive. Thus despite the fact that labour in agriculture and the informal sector were not organised within state-led industrialization's relations of production, they were intimately connected with reproducing its labour, and producing for its markets. This is a dominance marked not by numbers but by purpose.

State-led industrialization dominated because its conception of how relations of production should be organized defined the legal structure for labour relations. It also formed the ideological basis for mass support and provided the project around which its historical bloc could be organized. Thus the transformation of Peru under Fujimori was a transformation from an order dominated ideologically, economically and politically by state-led industrialization, to a state, society and economy dominated by its antithesis, neoliberalism.

Neoliberalism began as a school in economics that challenged the verities of Keynesianism and the welfare state. Contained within its nostrums was a mission to reduce the scope of the state to its former status as the nightwatchman state. But this state was also neutered in ways that would secure new relations of production based on an insecure and hence flexible labour force. Thus the new order is best described as neoliberal.

\section{Understanding Fujimori, Caesarism, Neopopulism and Transformations: The contributions of this thesis}

By examining the process of this transformation, this thesis offers a 
deeper understanding of the political and social effects of imposing neoliberal reforms on societies. This thesis refocuses our enquiries past the question of how political leaders obtain their power (democratically through elections or through coups) to how do these leaders exercise their powers (within constitutional limitations or by radically rewriting political institutions in ways that remove checks on their powers, and hence allows them to redesign their nations). Did the economic reforms actually require the dissolution of old representative institutions and did the reforms these leaders implemented radically alter power relationships within society? This shifts our enquiries from questioning how we impose economic reforms to questioning what is changed by these reforms. What kind of state was created by these reforms, who benefited from this new state, and who lost what in the shift from state-led industrialization to a neoliberal order?

This thesis also furthers the debate in the literature over neo-populism as both a concept and a phenomenon by explaining its structural causes. Work on neo-populism began with an adaptation of studies of earlier periods of populism to clarify commonalities between then and now, and to apply our understanding of the populist phenomenon to the present day. ${ }^{16}$ Populist movements in the

For the most useful explication of the different positions on populism as a concept see Kenneth M. Roberts, "Neoliberalism and the Transformation of Populism in Latin America", World Politics 48, no.1 (1996), 84-85. See also Alan Knight, "Populism and Neo-Populism in Latin America, especially Mexico, "Journal of Latin American Studies 30 (1998). For a global perspective see Margaret Canovan, "Populism for Political Theorists?," Journal of Political Ideologies 9, no.3 (October 2004), 242-243. 
early twentieth century in Latin America sought to integrate a new urban proletariat into the political system through a direct connection to a populist leader who came from outside the old landed oligarchy and offered redistribution without challenging capitalist relations of production. Neo-populism as a concept was used to understand a broad phenomenon across Latin America of political leaders who imposed neoliberal policies while they utilized populist methods to obtain political support to dismantle democratic checks on their power. ${ }^{17}$

But neo-populism was more than just a political strategy. This was also a response to an underlying crisis of representation and accumulation. Indeed this work also provides a causal explanation for the phenomena of neo-pluralism and "delegative democracy": Caesarism. Gramsci's theory of Caesarism offers an explanation of Fujimori's authoritarian shift to a caudillo who rode in and resolved

\footnotetext{
${ }^{17}$ For comparative studies based on Latin America see Paul Cammack, "The resurgence of populism in Latin America," Bulletin of Latin American Research 19 (2000), 149-161; Kurt Weyland, "Neopopulism and Neoliberalism in Latin America: Unexpected Affinities," Studies in Comparative International Development 31, no.3 (Fall 1996), 3-29; Philip Oxhorn, "Is the Century of Corporatism Over? Neoliberalism and the Rise of Neopluralism," in What kind of Market, What Kind of Democracy, Latin America in the Age of Neoliberalism, ed. Philip Oxhorn and Graciela Ducatenzeiler (University Park, Pennsylvania: Penn State Press, 1999), chapter 9. On Argentina see Celia Szusterman, "Carlos Saúl Menem: Variations on the Theme of Populism," Bulletin of Latin American Research 19 (2000), 193-206. On the Peruvian case see Steve Ellner, "The Contrasting Variants of the Populism of Hugo Chávez and Alberto Fujimori," Journal of Latin American Studies 35 (2003), 139-162; Bruce H. Kay, "Fujipopulism' and the Liberal State in Peru, 1990-1995," Journal of Interamerican Studies and World Affairs 38, no. 4 (Winter 1996), 55-98; John Crabtree, "Populisms Old and New: the Peruvian Case," Bulletin of Latin American Research 19 (2000), 163-176; and Kenneth M. Roberts, "Neoliberalism and the Transformation of Populism in Latin America", n21, supra.
} 
the contradictions of his political and civil societies from outside and above class conflicts (see Chapter One). This Caesarist dictator imposed a new order, a new set of political and economic relationships from outside previous political structures through a direct personal connection to those alienated from the previous order.

The major limitation of previous interpretations of Alberto Fujimori's rise and his time in office and the autogolpe lies in their emphasis on the political conjuncture. Maxwell A. Cameron, for example, has argued that an oppositiondominated Congress threatened reform with gridlock, a threat, which in combination with Fujimori's personal ambitions, prompted the autogolpe. ${ }^{18}$ Carol Wise argued that it was a personal preference for rule by fiat without debate that led to the autogolpe. ${ }^{19}$ While these approaches usefully map the exact political situation and its balance of forces, they fail to link the pattern of Fujimori's path to other historical examples or to its structural causes in a failure of this order and its hegemonic crisis.

Understanding Fujimori through the lens of Caesarism offers a different explanation of Fujimori's autogolpe of April 5, 1992. Instead of the autogolpe being driven by either the personal preferences of Fujimori or his political needs, what was required was the overhaul of Peru's political institutions so that they

Maxwell A. Cameron, Democracy and Authoritarianism in Peru: Political Coalitions and Social Change (New York: St. Martin's Press, 1994), 149-163. 19

Carol Wise, Reinventing the State: Economic Strategy and Institutional Change in Peru (Ann Arbour: The University of Michigan Press, 2003), 187. 
could fit the requirements of neoliberalism. To impose market discipline the state had to be restructured to eliminate those avenues subaltern groups had used to make their demands on the state. For example, it was after the autogolpe that the labour code was reformed to eliminate union power (see Chapter Six). Thus, in the case of Peru, Fujimori's democratic facade hid an authoritarian core which fit the needs of neoliberal transformation.

This work builds upon comparative work conducted by Karen Remmer and Leslie Armijo and Phillipe Faucher on the question of whether democratic or authoritarian regimes are more capable of instituting structural adjustment policies by shifting the focus from what factors helped democracies institute reforms to understanding what those factors indicate about changes to the underlying order ${ }^{20}$ In other words, this thesis reverses the question from what does democracy do for structural adjustment to what does structural adjustment do to democracy.

One of the major questions in the literature on structural adjustment programs is whether democratic or authoritarian governments are more effective in implementing reform. The argument was that because authoritarian governments were immune to political pressure from affected groups, they would

Karen L. Remmer, "The Politics of Economic Stabilization: IMF Standby Programs In Latin America", Comparative Politics 19, no.1 (October 1986), 1. See also Karen L. Remmer, "The Politics of Neoliberal Economic Reform", Studies in Comparative International Development 33, no. 2 (Summer 1998); Leslie Elliot Armijo and Phillipe Faucher, "We Have a Consensus': Explaining Political Support for Market Reforms in Latin America," Latin American Politics and Society 44, no. 2. 
impose change more effectively than newly installed democratic regimes. ${ }^{21}$ This thesis goes beyond questions about whether or not regimes that imposed structural adjustment were originally elected or were imposed by a coup, to delineating what the effect would be of having to impose structural reforms that would disarticulate the previous structures of representation and democratic consultation. One of the major characteristics of the new neoliberal state is that it refuses to consult or react to demands to intervene in class relations on behalf of subaltern groups (see Chapter Two). Thus whether the government is selected democratically or not, the transformation to a neoliberal government terminates previously existing structures that had secured consent. Just how democratic is a neoliberal state when it is predicated on ignoring the desires and demands of its citizens? How democratic can a state be when there are no structures that allow citizens to influence its actions? In the Peruvian case, the Caesarist regime of Fujimori did not replace the old with new avenues for citizens to influence the government's policies that effected their lives.

So a state like Peru that began the reform process with a democratic structure dissolved its previous linkages with society by, for example, radically altering the way it interacted with labour unions (see Chapter Six). Instead of conciliating and protecting union interests, the state ignored union demands and

21

Remmer, "The Politics of Economic Stabilization." Remmer noted a broad agreement in the literature on the point that stabilization policies threatened the political stability of democratic regimes. Authors cited include Guillermo O"Donnell, Richard Roet, Alejandro Foxley, William Skidmore and Robert K. Kaufman. 
imposed regulations that decimated the movement. Thus, even in countries with democratic facades like Peru, neoliberal reforms required the dissolution of old structures of representation below the level of presidential elections.

However, in a seminal comparative study of Latin American countries, Karen Remmer discovered that democratic regimes were actually more rigorous and effective at imposing austerity programs than authoritarian regimes. ${ }^{22}$ Thus, an authoritarian government was not a necessary condition for IMF stabilization. ${ }^{23}$ In a later study, Remmer stated that stabilization policies were less politically toxic and unpopular than had been previously assumed. ${ }^{24}$ The argument had been that these reforms were politically disastrous and hence the state's economic policies had to be insulated from domestic pressure. But instead of reform relying on state autonomy, Remmer argued that success or failure could be better predicted by other factors. Her comparative study found a correlation between the strength of the export sector, the weakness of opposition parties that were either socialist and Marxist, the weakness of the presidential mandate, the depths of the economic crisis, and the imposition and continuation of structural adjustment policies. ${ }^{25}$ Yet these factors really only indicated how much these societies had developed the relations of production of state-led

\footnotetext{
${ }^{22}$ Remmer, "The Politics of Economic Stabilization," 16.

${ }^{23}$ Remmer, "The Politics of Economic Stabilization," 19-20.

${ }^{24}$ Remmer, "The Politics of Neoliberal Economic Reform," 2.

${ }^{25}$ Remmer, "The Politics of Neoliberal Economic Reform," 13-15.
} 
industrialization dependent on domestic consumption, as well as the extent of the crisis of accumulation that bedevilled it.

Together what these factors really indicated is a correlation between the ability of governments to impose neoliberal reforms and whether or not state-led industrialization had created a strong enough support base in a non-export sector that provided socialist opposition parties with a base in a nascent industrial working class. This study builds on Remmer's work because it provides an explanation on how an underlying crisis of accumulation in state-led industrialization would weaken opposition even before structural adjustment was imposed. The economic crisis of state-led industrialization bankrupted its dependent firms, which led to massive layoffs and hence undermined the working classes (see Chapter Six). This helped to create a crisis of representation and a collapse in support for the socialist left in Peru (see Chapter One). If the crisis bankrupted the industrial sector dependent on domestic consumption, it also comparatively strengthened the export sector. In the Peruvian case, a weak presidential mandate actually pointed to a crisis of hegemony which meant the old order was vulnerable to being overthrown in favour of a new neoliberal order.

A more complex comparative study across Latin America of the factors that enabled neoliberal market reforms has been conducted by Leslie Armijo and Phillipe Faucher ${ }^{26}$. What is useful is their focus on how neoliberal reforms

\footnotetext{
${ }^{26}$ Armijo and Faucher, 15-16.
} 
affected domestic political balances. They argue that market reforms undermine those who are opposed to change while also generating popular and elite support. The reforms undermined their own opposition by eliminating what George Tsebelis described as veto points: political actors with the formal authority to withhold consent and hence veto policy reform. ${ }^{27}$ The larger the number of actors who had vetoes, the less likely it was that reform could be implemented. But what Armijo and Faucher also point out is that reform also created its own allies. The bourgeoisie was bribed with the proceeds of privatization through receiving preferential shares in privatized ventures and new markets for financial services from the privatization of pensions ${ }^{28}$ The masses supported market reforms because they erased hyperinflation and benefited especially those who were excluded from state-led industrialization's privileges in the informal and rural sectors. ${ }^{29}$ Thus, there was a constituency for neoliberalism: the poor and the financial bourgeoisie.

What this thesis does is to build on the patterns observed by Armijo and Faucher. Their work explains the existence of an electoral support base for neoliberal economic policies from the ambitious rich and the excluded. But what this thesis does is to explain why in the Peruvian case these reforms resulted in popular support for a Caesarist dictatorship. One of the duties of the Caesarist

\footnotetext{
${ }^{27}$ Armijo and Faucher, 15-16.

${ }^{28}$ Armijo and Faucher, 24-25.

${ }^{29}$ Armijo and Faucher, 30.
} 
dictator was to impose reform from outside the old system of checks and balances, of institutions with formal vetoes as well as those who have informal ones. The judiciary and the legislature usually have formal vetoes, while others like the labour movement, the bureaucracy, the officer corps and the bourgeoisie may have informal vetoes. Since the power of these groups is rooted within the institutions of the previous order, transformations inherently threaten their interests. So during the period of transformation vetoes must be suspended to allow substantive reforms. But without the institutionalized connections embodied in the party system, Caesarist dictators need to build support through the direct disbursement of rewards to followers which they usually did through corruption.

Yet the corruption involved in privatization in Peru could also be interpreted as the process of shifting ownership of the means of production as one order is transformed into another, from state-led capitalism to the savage capitalism of neoliberalism. Instead of deriving their power and wealth through the mercantilism of protected markets and state subsidies, the new bourgeoisie gained wealth from the proceeds of undervalued privatized firms, providing financial services for privatized pension funds and the across the board compression of wages. ${ }^{30}$ As the order was changed, who owned what also changed, but even more importantly how they gained their wealth and power

While mercantilism refers to a specific industrial strategy with a goal of maximizing foreign exchange surpluses through protectionism, neoliberals use the term to describe rent seeking behaviour (see Chapter Three for a discussion on neoliberal theorists and Peruvian practitioners). 
changed as well.

In the case of Peru, the veto point of the Congress was erased by the collapse of support for the parties, for no one cared when Fujimori dismantled them with the autogolpe. ${ }^{31}$ Veto points could only have survived when institutions were broadly accepted as legitimate. Formal authority required moral authority to survive a crisis.

One of the contributions of this thesis is an exploration of how these veto points were dissolved by the political, moral and economic implosion of the previous order. Not only were the political parties defenestrated by their own contradictions when faced with crises, but their subordinate civil society organisations also collapsed. The example in civil society explored by this thesis is that of the labour movement (see Chapter Six). The collapse of support for these civil society organisations meant they could be dissolved by a Caesarist dictator. Ironically, in the Peruvian case it seems that the very extremity of the crisis of the entire order may have meant that there were no organisations with any legitimacy left and therefore only a Caesarist dictator like Fujimori could have resolved the crisis and imposed a new neoliberal order.

This concept of Caesarism also develops our understanding of the causes behind the phenomenon of neo-populism. ${ }^{32}$ Neo-populism has been utilized as a

A respected, neutral pollster found that $71 \%$ of the electorate supported the autogolpe. Mirko Lauer, Diás Divididos: Columnas políticas de los Años 90 (Lima, Adec Atc, 1994) 54.

32

The first wave of populism in Latin America, under leaders like Peron in 
way of understanding a wave of new style leaders from Fujimori in Peru, to Collor de Melo in Brazil and Menem in Argentina. While conventional approaches correctly depict the new style of direct representation and how neoliberalism generated mass support, they fail to incorporate the crucial role that the implosion of the previous order in an economic crisis had in creating the political vacuum filled by neo-populists. ${ }^{33}$.

What this thesis adds to this debate is an understanding of how these characteristics of populism and neo-populism are actually symptoms of a deeper malaise. The theory of Caesarism locates the arrival of populism and neopopulism within the particular structural situation of an impasse wherein a crisis has overwhelmed the previous order, and forces that would impose a new order either do not yet exist or lack the necessary strength. Thus the populism of early state-led industrialization reflected a crisis in the primary goods export-led economy of the early twentieth century, wherein the old landlord oligarchy lost its hegemony in the crisis of the Depression. The current era of neo-populism was presaged by the crisis of state-led industrialization. Despite the terminal crises of the old, new social forces were not strong enough to impose a new order on their own. Instead, a caudillo, a Caesarist dictator appeared to resolve the crisis and dissolve the old bankrupt structures of mediation and control and impose a new

Argentina and Vargas in Brazil, resulted in the incorporation of the urban working class within the legal and political system. Populists actually delivered new labour rights and services to their supporters, while neo-populists presided over the dissolution of labour rights and access to services.

${ }^{33}$ See, for example, Weyland, 10. 
neoliberal order. The Caesarist dictator appealed to subaltern groups through personal ties rather than creating new autonomous institutions that might challenge the interests of the emerging export and financial bourgeoisie. Populism, then and now, relied on the distribution of favours to individually corrupt subaltern leaders and the distribution of rewards to purchase the loyalty of mass subaltern classes rather than to challenge the structures of domination. For example, Fujimori distributed satellite dishes for free to rural communities instead of devolving the power to tax mining corporations to municipalities so that local communities could decide their own priorities. In the long run, irresolvable contradictions were then papered over by clientelistic distribution of resources, a redistribution that was unsustainable under both populism and neopopulism.

While Caesarism explained the structural causes of populism and neopopulism, other authors' observations about the situation offered further insights into the support base of neo-populism. As Philip Oxhorn argued, the adoption of neoliberalism resulted in the replacement of state corporatism as the major mode of interest intermediation with what he described as neo-pluralism across Latin America. ${ }^{34}$ Neo-pluralism then, was a description of the political style and practises of the new neoliberal regimes. Neo-pluralism replaced the controlled inclusion of state-led industrialization through unions, with exclusion by means of

\footnotetext{
${ }^{34}$ Oxhorn, 200.
} 
increased social atomization and the weakening of labour unions ${ }^{35}$ At the same time as civil society organisations of the subaltern classes were weakened, the political system made a transition towards liberal democracy, and hence the system became more formally open and pluralistic. Yet, as he also noted, neoliberalism was predicated on the construction of political apathy and increased social atomization. ${ }^{36}$ This combination meant that while these societies moved towards regular elections, the system was predicated on preventing citizen participation and especially preventing the amalgamation of their demands for government action.

Oxhorn also noted that an inherent cause for the political failure of stateled industrialization was the privileged position it granted union members. The political problem was that those outside the industrial sector had to be excluded from state-led industrialization's political and economic benefits. ${ }^{37}$ In addition, since younger graduates of its expanded educational system could not be absorbed, their demand for social mobility could not be satisfied. ${ }^{38}$ An inability to satisfy demands from these groups then led to economic populism, the debt crisis and economic collapse.

Those groups that were excluded from the fruits of state-led

${ }^{35}$ Oxhorn, 196, 198, 216.

${ }^{36}$ Oxhorn, 216.

${ }^{37}$ Oxhorn, 198.

${ }^{38}$ Oxhorn, 199. 
industrialization formed the social base of support for neo-populism. The rural masses became available with the decline of the power of landowners due to land reform undertaken by the leftist military government of $1968-1975 .{ }^{39} \mathrm{Neo}-$ populist individual leaders also based their support on new migrants to the cities who worked in the informal sector, a marginalised mass who had not been absorbed into the industrial sector. ${ }^{40}$ Neo-populists caudillos based their appeals to the informal and rural sectors on neoliberal criticisms of the market-distorting privileges granted by SLI to the organised workers in industry (see Chapter Three for details on Peru) ${ }^{41}$ But this appeal went beyond schadenfreude (pleasure at others pain), for the pledge to end hyperinflation also offered protection to the most vulnerable.

Those previously excluded from the spoils of SLI were wooed by a neopopulist spending spree paid by the proceeds of privatization. For example, Fujimori's expenditure of $\$ 875$ million (US) on poverty alleviation projects in the run-up to the 1995 elections came from revenues generated by privatization. ${ }^{42}$ These funds were directly funnelled through the Office of the Presidency, and were focussed on the highland areas that had voted against Fujimori's new

\footnotetext{
${ }^{39}$ Weyland, 6.

${ }^{40}$ Weyland, 6.

${ }^{41}$ Weyland, 7.

${ }^{42}$ Kay, 68.
} 
constitution in $1993 .^{43}$ The political result of this spending was the return to the fold of the marginalised, as Fujimori swept these areas in $1995 .^{44}$ Thus neoliberal policies generated the surpluses that paid for populist redistribution to the marginalised and hence generated mass support for restructuring.

Ironically though, neoliberal policies contained the seeds of their own destruction. Once the restructuring via privatization was complete, funds for populist distributions dried up. Without resources to bribe the masses, neoliberalism lacked the means to buy loyalty. As we have seen in Bolivia, Venezuela and Peru, these masses then became available to the appeals of ethnically based anti-neoliberal populist leaders like Morales, Chavez and Humala.

But beyond political style, was there more to the similarities between the populism of early SLI and the neo-populism of early neoliberalism? According to Paul Cammack and Ernesto Laclau, the similarity had less to do with style and more to do with a similarity in structural conjunctures. As Ernesto Laclau has argued, populism utilized a discourse based on claims of democratic rights for subaltern classes to challenge the status quo and hence the ideology of the dominant bloc. ${ }^{45}$ But underneath populist rhetoric there was always a power

\footnotetext{
${ }^{43}$ Kay, 81.

44

See Kay, 87-89, for an analysis of the correlation between direct spending controlled by Fujimori on these areas and his improvement in votes by 1995 . 45

Emesto Laclau, Politics and Ideology in Marxist Theory (London, New Left Books, 1977), 174.
} 
struggle within the dominant bloc. Populism occurred when an insurgent fraction within the bloc appealed to the masses for its support for the transformation of the state to reflect that fraction's interests. ${ }^{46}$ For example, Peronism was an expression of the concrete struggle of the national bourgeoisie against the landed oligarchy over the form of the state. Yet this definition of populism avoided an identification with the particular historical conjuncture of early SLI by locating its cause in any crisis of hegemony with a specific characteristic of an anti-establishment appeal to the masses for allies against the old masters. ${ }^{47}$

If populism reflected a crisis of hegemony, what did these crises reflect? According to Paul Cammack, a populist crisis was a reflection of a crisis in political institutions and "a deeper structural crisis affecting the reproduction of capitalist accumulation and the political hegemony of capitalism.." ${ }^{48}$ The orders that were based on economic liberalism in the early twentieth century and SLI were overwhelmed by first economic then by political crises that could not be resolved within the status quo. Populism appeared in the context of a transition that could not be managed by existing institutions. The resulting hegemonic crises were then resolved by populist and then latterly neo-populist leaders who imposed a new order.

What this thesis adds to our understanding of populism and neo-populism

\footnotetext{
${ }^{46}$ Laclau, 173.

${ }^{47}$ Cammack, 152.

${ }^{48}$ Cammack, 155.
} 
is an explanation of how these phenomena reflected a deeper structural failure in their orders. Both populism and neo-populism are symptoms of the collapse of old orders wherein the old structures of control, mediation and legitimation have collapsed. Their ideological promises have failed. In the case of Peruvian SLI, the promises of President Alan García (1985-1990) led to an economic dead-end wherein old promises of protection and prosperity for workers in the industrial sector could not be fulfilled. Just as crucially, it had become more and more obvious that the dreams of Fordist prosperity could not and would not be extended to others. Those who had been excluded became available to the populist appeal of an outsider who used an appeal of anti-politics against the corrupt old political class that had failed. But neo-populists offered more than a negative appeal, they offered practical benefits to the excluded in the form of a populist distribution of goods financed by the proceeds of privatization. Thus an hegemonic crisis in ideology from an economic crisis in the regime of accumulation resulted in a political crisis of representation resolved by a Caesarist leader who imposed a new order from outside.

The use of this theory of Caesarism also marks a development of the theory of delegative democracy advanced by Guillermo O'Donnell. O'Donnell argued that the depths of the economic crisis in Latin America had resulted in the creation of delegative democracies wherein "whoever wins election to the presidency is thereby entitled to govern as he or she sees fit, constrained only by the hard facts of existing power relations and by a constitutionally limited term of 
office. ${ }^{49}$ In other words, the electorate delegated all power to the president to resolve the economic crisis no matter what policy promises he or she had made. The president's authority extended to reforming all economic institutions and arrangements including the labour code. These reforms could be imposed without legislative debate and without veto by political parties or institutional actors. The president's responsibility was to resolve the crisis.

Caesarism allows us to understand that the turn to delegation by the electorate was more than a desperate response to an ongoing economic crisis. The willingness of the electorate to delegate authority also marked their abandonment of allegiance to the ideas and institutions of the old order. The old had died; the president's task was to bury the old political system and its economy and impose the new.

In the Peruvian case, the incident that marked the Caesarist moment was the autogolpe or self coup of April 5, 1992, when President Fujimori used the armed forces to dissolve the legislature, the judiciary and the constitution. This moment also marked controversy in the specialist literature on Peru over the causes of the autogolpe (see below). Once again, this thesis offers an expanded explanation based on Caesarism that transforms our understanding from just its political conjuncture to a structural mission to resolve an impasse by creating new institutions to serve a new order.

49

Guillermo O'Donnell, " Delegative Democracy," in The Global Resurgence of Democracy, $2^{\text {nd }}$ edition, ed. Larry Diamond and Marc F. Plattner (Baltimore: Johns Hopkins University Press, 1996), 98. 
The autogolpe instituted by President Alberto Fujimori sparked a debate in the literature as to its causes. The opinions can be roughly divided into those who blame the coup on Fujimori's authoritarian personality and personal political needs, and his political supporters who argued that there was a developing political impasse that needed resolution. Those who argued that Fujimori preferred authoritarian political solutions included former members of his cabinet Carlos Amat y Leon and Guido Pennano (see Chapter Three). Academics based in the north have tended to argue that the need to silence Fujimori's personal political scandals as well as threats to the military were the primary motivations for the coup..$^{50}$ Whether or not the autogolpe was driven by necessity or mere opportunism, both sides see this as caused by Fujimori's personal desire for an authoritarian regime. In contrast, this thesis offers an explanation beyond that political moment to focus on the structural impasse in the transition to a new order.

The application of Marx's understanding of Bonaparte and Gramsci's theory of Caesarism to this case shifts our understanding of the causes of the autogolpe from motivations grounded in that political moment to the transformation to a new order. The demands of transforming a order in a

50

See John Sheahan, Searching For a Better Society. The Peruvian economy from 1950 (University Park, Pennsylvania: The Pennsylvania University Press, 1999), 35-36; also Charles Kenney, "Por Que el Autogolpe?," in Los Enigmas del Poder: Fujimori 1990-1996, ed. Fernando Tuesta Soldevilla (Lima: Fundacion Friedrich Ebert, 1996), 85-86; and Enrique Obando, "Fujimori and the Military," in Fujimori's Peru: The Political Economy, ed. John Crabtree and Jim Thomas (London: Institute of Latin American Studies, 1998), 201. 
situation where the previous political and economic situation had imploded (see Chapter One), in turn required a Caesarist dictator who could transform everything from outside the previous system, (see Chapter Three for more details). From this perspective, Fujimori's part was driven less by his own vanity, than by the needs and opportunities of the situation.

Some commentators argued that the autogolpe simply camouflaged a power grab by justifying it in the name of removing obstacles to reform. One of the motivations for the coup was a desire to bury a personal scandal spearheaded by Fujimori's separated wife. Just before the coup, Fujimori's wife Susanna Higuchi had accused her husband and his brother Santiago of selling off donated Japanese used clothing for their personal profit. The autogolpe conveniently dissolved a Congressional commission investigating the case. ${ }^{51}$

But Congress was not guilty of conducting a vendetta against the President or being needlessly obstructive. As Cynthia McClintock pointed out, Congress had only modified or revoked $22 \%$ of Fujimori's decrees while $78 \%$ of them were passed unchanged..$^{52}$ Furthermore, Cambio 90 (Change 90 , Fujimori's party) and Fredemo, Vargas Llosa's movement, together easily controlled a Congressional majority. The consensus amongst the Peruvian political class was that Fujimori had tried to provoke Congress into resisting his decrees so that

\footnotetext{
${ }^{51}$ Conaghan, 311.

${ }^{52}$ McClintock, 64.
} 
Congressional obstruction could be used to justify a preplanned coup. ${ }^{53}$

Therefore, McClintock argued that Fujimori dissolved Congress and the Judiciary to ensure that there were no institutional checks on his power.

But beyond Fujimori's desire for unchecked power, the autogolpe served to cement his alliance with the military. The autogolpe not only pre-empted investigations into the President's actions, but it also pre-empted human rights complaints against the military. This veto by coup cemented the Armed Forces' support for the President. ${ }^{54}$ Since there was already a plan, Plan Verde, within the Armed Forces for a military civilian government that would implement structural adjustment within an authoritarian regime, some have argued that the autogolpe pre-empted a military coup. ${ }^{55}$ But whatever Fujimori's fears were of a coup, Congress's veto of new security laws for the war with Sendero had already alienated the military. The autogolpe gave Fujimori the power to implement his security reforms, reforms which gave the military an unfettered hand in its war with Sendero. ${ }^{56}$ Thus, the common enemy of Congress united the military and Fujimori.

While no coup can ever be justified, the military's support for the autogolpe at least reflected the sense that there was a crisis afflicting Peru. Plan

\footnotetext{
${ }^{53}$ McClintock, 64.

${ }^{54}$ Sheahan, 35-36.

${ }^{55}$ Kenney, 85-86.

${ }^{56}$ Obando, 201.
} 
Verde indicated to Fujimori that he could use his economic reforms to cement his alliance with the military. Thus, even opinion within the military reflected a sense of the underlying crisis of accumulation in the economy.

Whether or not there was a need for an autogolpe to impose reform, Fujimori's own political supporters argued that Congressional resistance to reform had caused a growing political crisis. Carlos Torres y Torres Lara argued that the autogolpe merely prevented a Congressional coup whereby Congress had intended to remove the President for reasons of "moral incapacity." The threat was that the First Vice- President Maximillo San Roman had disagreed publicly with the President, and was making overtures to the opposition. By making himself seem "presidential," San Roman offered the opposition the opportunity to impeach Fujimori and replace him and hence derail the reform. ${ }^{58}$

Carlos Boloña, Fujimori's Minister of Finance, thought that the major threat was the political resurgence of Alan García. According to Boloña, García with his "characteristic irresponsibility" was rapidly gaining power in Congress, and was using that power to derail the reform process. ${ }^{59}$ The autogolpe was

57

Torres y Torres Lara, 80-81. Ironically it was this process that Congress used in 2000 to remove Fujimori from office when it first refused his resignation, and then impeached him.

${ }^{58}$ Torres y Torres Lara, 82-100.

59

Carlos Boloña, "The Viability of Alberto Fujimori's Economic Strategy," in The Peruvian Economy and Structural Adjustment: Past Present and Future, ed. Efrain Gonzales de Olarte (Miami: North South Center Press, University of Miami Press, 1996), 220. 
justified by the need to protect the reform process.

President Albert Fujimori publicly justified the autogolpe in his traditional Presidential address to the new constituent Assembly on Independence day, July 28,1993 . He stated that:

On that day, 5 April 1992, I faced a predicament: either Peru continued walking, quickly heading to the abyss of anarchy and chaos, pushed by terrorism and before the passiveness of the state organization, or I took the risk of providing the state with the necessary instruments for putting and end to that threat. ${ }^{60}$

In his address to the OAS, Fujimori claimed to be justified in his dissolution of Congress by Peru's need to dissolve the old corrupt system of what he described as partidocracia. ${ }^{61}$ Fujimori argued that Peru had been brought to the edge of the abyss by the selfish antics of a corrupt oligarchy centered in the political parties. ${ }^{62}$ The autogolpe broke their corrupt hold on Peru, and he promised to give Peru an authentic democracy.

While Fujimori and his cabinet supporters' comments may have been politically self serving, even their self justification points the way to one of the significant contributions of this thesis. The arguments of these political players revealed a growing sense that the reform process was in increasing danger of being blocked by opposition forces. But even more important were the

60

Alberto Fujimori, cited in "A Momentous Decision," The Peru Reader, ed. Orin Starn, Carlos Ivan Degregorri and Robin Kirk (Durham: Duke University Press, 1995), 438-439.

${ }^{61}$ Kenney, 101.

${ }^{62}$ Kenney, 100-102. 
justifications that Peru needed reforms to its institutions to overcome its economic, security and political crises. Their mission to overhaul Peru's institutional structures directed our attention away from the merely conjunctural to the structural causes underlying the autogolpe.

Beyond theories about the meaning of the autogolpe, this thesis offers a more useful and accurate understanding of the significance of the radical economic policy shift undertaken by Fujimori. One school of thought perceived the neoliberal shift under Fujimori as simply being the latest and last experiment in an ongoing attempt to find a successful economic strategy that would benefit all ${ }^{63}$ or a state structure that could spur development. ${ }^{64}$ The perspective this thesis offers integrates changes in the state with changes in economic policy and demonstrates that to change either required changes in both.

This shift was also described as part of a global transformation to a neoliberal world order. According to Teivo Teivainen, this shift occurred within a global context of increasing the autonomy of economy from democratic control. ${ }^{65}$ As Michel Chossudovsky has also argued, the Fujimori shift was part of a strategy of the "globalization of poverty," as part of a "global cheap labour

\footnotetext{
${ }^{63}$ Sheahan, 175.

${ }^{64}$ See Wise, Reinventing the State, chapter one. 65

See Teivo Teivanen, Enter Economism, Exit Politics: Experts, Economic Policy and the Damage to Democracy (London: Zed Books, 2002), especially chapters 8-10.
} 
economy combined with a search for consumer markets on the other. ${ }^{n 6}$ This thesis demonstrates that the shift in Peru was part of a global process encouraged and indeed required by the IFIs (see Chapter Four). This thesis also demonstrates how these policies then restructured Peru to the benefit of the centre (see Chapter Five).

This thesis also offers a rebuttal in two ways to those who would argue that the IFIs played a positive role in pushing for democracy, human rights and the reform of government through political conditionality. First, this study is premised on a definition of democracy that goes beyond Schumpeterian definitions that limit democracy to elections and hence suffer the fallacy of "electoralism." ${ }^{167}$ Democracy is not merely a method by which we choose our rulers, it is also more than a set of rules by which we ensure that we can conduct an open and fair debate about policy options. If democracy is truly different from dictatorship, then it must offer a means by which citizens can influence decisions governments make, decisions that affect their lives. Elections only have meaning when they offer citizens choices between substantive alternatives. When choice is circumscribed to only those neoliberal policy options acceptable to the IFIs, choice is eliminated. As Manfred Bienefeld wrote, "Just as Henry Ford once

Michel Chossudovsky, The Globalization of Poverty: Impacts of IMF and World Bank Reforms (Halifax: Fernwood Publishing, 1997), 17; also chapter ten for Chossudovsky's account of the Fujimori shift.

67

Terry Lynn Karl and Philippe C. Schmitter, "What Democracy Is ... and Is Not," in The Global Resurgence of Democracy, ed. Larry Diamond and Marc F. Plattner (Baltimore: The Johns Hopkins University Press, 1996), 52. 
declared his Model-T to be available 'in any colour, as long as it is black,' bemused electorates now find that they can choose 'any policy regime, so long as it was the neoliberal one." ${ }^{68}$ Without choices, elections deteriorate into empty popularity contests and have as much meaning as beauty pageants.

Secondly, this thesis explores the reality of interventions by the IFIs, how they ensured that there was no alternative to neoliberalism and hence made moot any democratic choices. By examining how the IFls were able to enforce their preference for neoliberal solutions, this thesis integrates how national systems are shaped within a global order. Furthermore, as this thesis will demonstrate, when the IFIs were given the choice between supporting "right" policy or democracy in the aftermath of the autogolpe, IFIs chose to protect the dictator to protect their policies. This thesis will prove that the IFI's made their priorities clear: neoliberalism over democracy.

While this thesis contributes to our understanding of transformations through the use of the concept of orders, a concept that is the most significant theoretical contribution of this thesis. Instead of looking for the genesis of a transformation in relations of production or structures of the state or the ideologies that legitimate them, this thesis explored and utilized the theory of structural affinity to explore the interdependence of all three. Yet, as this thesis will demonstrate, change at one level in the structures of representation allowed

Manfred Bienefeld, "Structural Adjustment and the Prospects for Democracy in Southern Africa," in Debating Development Discourse, ed. David B. Moore and Gerard J. Schmitz (London: Macmillan Press Ltd., 1995), 92-93. 
changes in another (social relations of production) that resulted in the fundamental transformation of all.

\section{Methodology}

The central research question of this thesis, namely, the nature of transformation in Peru, generated a research strategy that was based on a Gramsciian perspective. Based on the insights of structural affinity, the crucial relationships to explore were how each of the three poles of ideology, state, and economy reinforced each other in both the process of transformation and in the creation of a relatively stable neoliberal order.

For example, neoliberalism as an ideology articulated new normative value claims that justified the elimination of the institutions and arrangements of the previous order. Thus, neoliberalism attacked state-led industrialization not merely for being ineffective, but also on moral grounds (see Chapter Two). Neoliberal theorists also undermined the moral claims of the labour movement by inverting its claims of solidarity and equity into demands for privilege based on coercion (see Chapter Two). Neoliberal values then reinforced a neoliberal state and legitimated relations of production based on the destruction of union rights. Thus an approach based on structural affinity generated a research agenda into neoliberalism that sought to uncover how this ideology refuted the values of the previous order while articulating values that supported the process of transformation and the new order. 
Similarly, structural affinity was also reflected in the new structure of the state. Reductions in the role of the state were demanded by the nostrums of neoliberal ideologues, which then reinforced changes made in the economy. Changes to the economy then expressed neoliberal ideas and undermined the proponents of the old order while enforcing new strategies of domination. The key for research to test these propositions was to explore the reinforcing relationships for both transformation and then the reproduction of a new neoliberal order.

While studying reinforcing relationships explains how the process moved forward, who drove the process still requires an explanation. A Gramsciian theoretical perspective generated useful directions for a research strategy by focussing attention on Fujimori as a Caesarist dictator, on technocrats as the cosmopolitan intellectuals who imposed a new neoliberal order from outside and on the IFIs as the purveyors and enforcers of a new neoliberal international order.

In order to understand the role of the technocrats who imposed neoliberal reforms on Peru, fourteen interviews were conducted with some of the key players in the summer of 1997 . The most important author of these reforms was the former Minister of the Economy, Carlos Boloña, who was interviewed for this thesis in August 1997. Because Boloña was the architect of Fujimori's reforms, his perspective on the role of technocrats and his intention for the reform was crucial. Other subjects interviewed ranged from the current Peruvian President to former cabinet ministers, to deputy ministers and heads of programs to 
officials and members of the civil service ${ }^{69}$ Use was also made of their published works, as well as interviews published in Peru.

Interview subjects were asked about their opinions on the following topics. They were asked about their family backgrounds, their educational backgrounds, how they were recruited into government, whether or not they thought that economics was a science that had one answer, what they thought the role of labour unions was in setting policy and their opinion of Fujimori's actions around press freedoms. The purpose behind asking about family, educational backgrounds and recruitment was to establish how they formed a cohesive group, what their connections were to the elites and to understand how they came to prominence. The question was did they have any organic links to the bourgeoisie in the sense that they had been working in the private sector or that they had been training the managerial leaders or the heirs of the elite or were they themselves the offspring of the business or political elites of Peru.

Questions about how they were appointed and how neutral government appointments had become were to determine if there had been a shift in the political culture of Peru. Questions were also asked about policy issues around the reform of the labour code, to determine if there had been a shift from norms of consultation and accommodation.

Questions about how policy should be determined were to ascertain whether or not they saw policy as a political or only technical choice. What they

\footnotetext{
${ }^{69}$ For a sample of the questions, see Appendix A.
} 
were silent about and what they disagreed with was most instructive, even when it resulted in discarding previous lines of inquiry. For example, when they unanimously expressed the opinion that economics was not a science and that it involved political choices, this meant that a theory that a belief in the scientific certainty of economics had driven the imposition of policy was discarded. The questions listed above were designed to elicit comments about their vision of the place of technocrats and labour unions in setting policy. Because of concerns for the personal security and careers of the subjects interviewed, care has been taken to not identify individuals and their opinions, except in cases where they have already published their opinions. Extensive use was also made of Peruvian newspapers, journal articles, pamphlets and magazines.

Beyond questions about the agents of change are questions about the scope of what was transformed. But if the transformation to a neoliberal order affected more than the superstructure of the realm of formal institutions, these changes would have also been reflected at the level of what Robert Cox described as the "mode of the social relations of production." ${ }^{170}$ According to Cox, the state-society complex is defined by a dominant mode of organizing labour and the extraction of surplus value. ${ }^{71}$ If state-led industrialization was in crisis before the transformation to neoliberalism, then its institutions within civil society

70

Robert W. Cox, Production, Power, and World Order. Social Forces in the Making of History (New York: Columbia University Press, 1987), 32.

${ }^{71} \operatorname{Cox}, 11$. 
would have been in crisis as well. Therefore, the question must be asked: was there a crisis of representation within the labour movement? Were the problems of the labour movement not merely threats caused by its political enemies, were they also caused by its own internal contradictions? How did the economic crisis affect the political tactics of the labour movement? Thus an examination of the internal and strategic position of the labour movement before transformation revealed internal problems and weaknesses of state-led industrialization before its destruction.

If the transformation towards a neoliberal economic model changed statesociety relations, then the rules surrounding labour relations must have changed as well. Thus reforms to the labour code revealed how the game was changed and state-led industrialization was dismantled for the working classes. But beyond merely changing the rules, the following question needs to be asked: were the rules for unions changed in ways that disarticulated their previous formation? Were the rules not merely changed to reform unions, but also to prevent a rejuvenated labour movement from challenging neoliberalism? In order to ascertain the effects of neoliberal reforms on the union movement in Peru, extensive analysis was conducted from Peruvian sources. Interviews were conducted with six experts on labour law, union leaders, union educators and experts on the situation for labour in Peru. Written sources included Peruvian journals on labour issues and publications by Peruvian think tanks and pamphlets for public education. The relevant decree legislation was also reviewed. 
However, while the Peruvian case may have been more explicitly conducted against the wishes of the labour movement than elsewhere in Latin America, the drive to weaken the power of labour unions and flexibilize labour markets was part of a global trend. Indeed some of the worst features of the Peruvian attack on organized labour were lifted from the Chilean labour code. For example, the section that workers were deemed to have resigned their positions if the strike was prolonged was taken directly from Pinochet's labour code.

But before the structure of the argument can be delineated, the characteristics of this transformation that were specific only to the Peruvian case need to be outlined. Those elements that reflected only the particular political conjuncture of the Peruvian case need to be isolated so that conclusions can be generalized beyond Peru. However, as the following section will explain, characteristics that were exaggerated in Peru may in fact clarify rather than obscure how the process of transformation took place.

\section{Peru's Distinctiveness}

While structural adjustment has been imposed across the periphery, there are certain aspects to the Peruvian case that were either unique or more explicit and must therefore be taken into account in order to assess the applicability of lessons learned from this case. Most of the aspects of the Peruvian case that seemed to be unique, were in fact only exaggerations of tendencies on display across Latin America. In other parts of Latin America, organizations were able to 
adapt and yet were utterly transformed. Political parties like the Peronists of Argentina changed their social base, converted to a new ideology, and reversed their policies while claiming to be the same party. Since the party had not changed, superficially there was no change in representation. Thus the extreme case of Peru offered clarity to processes that were obscured by the adaptability of social organisations elsewhere.

One of the factors that was more explicit in Peru compared to elsewhere in Latin America were the ethnic and geographic identities that divided it. Both Bolivia and Ecuador share this ethnic divide, a division that has come to the fore recently with indigenous political rebellions that have derailed presidencies and privatization programs. ${ }^{72}$ In Peru, ethnicity is a complex construction wherein racial identity is fluid and indicates location, language and class, instead of being solely defined by genetics. In Peruvian terms, money whitens. The three major categories for race are criollo, cholo and indio. Those who tend to be classified as criollo, tend to be of European ancestry, speak Spanish and live in the wealthy inner city communities of Lima like Miraflores, Baranco and San Isidro. Those who would be described as cholo would tend to be those whose families had migrated more recently from the Sierra to the cities and Lima, who tend to be of mixed indigenous and European ancestry and speak Spanish.

72

During June 2005, in Bolivia, protests based in its indigenous communities over plans for natural gas led to the fall of the President Sánchez de Lozada. In Ecuador, similar protests have toppled other programs and presidents. However, an in-depth examination of these cases lies beyond the scope of this thesis. 
Those who are regarded as cholo are least culturally mestizos in the sense that their experience bridges the world of Lima and the Sierra. Their status lies in between the crillio elite and the indios. ${ }^{73}$ The indios live in rural areas in the Sierra and speak Quechua as their mother tongue. Yet at the same time, someone whose family was well connected would be regarded as criollo, despite obvious indigenous ancestry.

But while Peru is riven by its ethnic conflicts, these conflicts are not enough in themselves to explain the rise of Fujimori and the fall of the previous political parties. Because this tension has always been present, its existence is not a sufficient cause to explain the crisis of representation. These divisions merely exacerbated the crisis of representation when it was sparked by a crisis of accumulation. Ethnic tension meant that when a crisis of accumulation disrupted the historic bloc, elements of the bloc lacked the legitimacy necessary to rearticulate the order without resorting to a Caesarist dictatorship (see Chapter One). Thus while ethnic tension exacerbated the political effects of a transformation, it did not cause them.

However, what was unique about the Peruvian case was the decimation of civil society by the forces of revolution rather than reaction. In Latin America, Peru was cursed with an active and unusually destructive guerrilla movement, Sendero Luminoso (Shining Path). Colombia, Guatemala, El Salvador and

73

Rodolfo Stavenhagen, "Social Dimensions, Ethnicity," in Democracy in Latin America: Reconstructing Political Society, ed. Manuel Antonio Garretón M. and Edward Newman (New York: United Nations University Press, 2001), 176. 
Nicaragua all suffered from civil wars and insurgencies during the 1980's and 1990 's. In these countries the armed forces led the assault on civil society. However, Sendero's strategy of destroying Peru's rural infrastructure and annihilating all civil society leaders who were not Senderistas resulted in mass dislocation in the countryside, and the decimation and weakening of urban civil society (see Chapter One and Six for more details). Because Sendero uniquely targeted, rather than allied itself with, elements in civil society, it undermined all organizations that could have resisted structural adjustment (see Chapter One). Also because Sendero was Communist, it delegitimated the Marxist left wing civil society organizations rooted in el pueblo that had resisted neoliberalism. Ironically, a Maoist insurgency undermined proletarian and subaltern defences and hence helped a right wing capitalist revolution.

One of the unusual aspects of the Peruvian case was its late timing in both the shift to state-led industrialization and its transformation to neoliberalism. In comparison to the rest of Latin America, Peru was a late comer to SLI. In the rest of Latin America, state-led industrialization based on ISI had been the dominant economic paradigm since the crisis of the Great Depression. ${ }^{74}$ But in Peru, liberal laissez faire free-trade economic policies were followed from independence to $1963 .^{75}$ State-led intervention to drive development had a brief history in Peru, peaking during the military government of President Velasco

\footnotetext{
${ }^{74}$ Teivanen, 49.

${ }^{75}$ Teivanen, 49.
} 
$(1968-1975))^{76}$ The result of this late comer status was a shallowly rooted identification by workers with their class. The recurrent economic crises of the 1970's and 1980's eroded the power of unions to defend their members' interests which in turn eroded their attachment to a working class identity. ${ }^{77}$ Because industrialization was a late phenomenon in Peru, there was still a large segment of the working class who had migrated fairly recently from the Sierra to Lima. For these workers, membership in the working class was only a temporary stage on the road to establishing their own businesses ${ }^{78}$ However while class identity was weak, class was still the vector through which the cholos and campesinos (farmers) were integrated into the political system. But despite a shallowly rooted identification with industrialization, it was in Peru that a revolt against pressure from the IFl's to adopt structural adjustment policies took place.

From 1985-1990 President Alan García had led one of the few explicit rebellions against the IFIs and debt repayment. García had openly refused to pay more than $10 \%$ of Peru's foreign exchange earnings on debt repayments and instead tried to reactivate production by reigniting demand (see Chapter One). This debt strike resulted in Peru being blacklisted by the IFls and hence ostracised from international finance. The resulting economic disaster proved

\footnotetext{
${ }^{76}$ Teivanen, 51-56.

77

Jorge Parodi, To Be a Worker: Identity and Politics in Peru (Chapel Hill: The University of North Carolina Press, 2000), 152. For more details on the erosion of class identity and their support for unions see Chapter Six of this thesis.

${ }^{78}$ Parodi, 142.
} 
that refusing to deal with the IFI's and just deepening state-led industrialization was not a feasible alternative.

Like its late start in state-led industrialization, Peru was also late in its implementation of structural adjustment, an adjustment that was heavily politically contested (see Chapters One, Three, Four and Six for details). Despite the demonstration effect of shock policies in the rest of Latin America, Peruvians rejected them at the polls in 1990 . The spectre of the social costs of shock policies helped defeat the candidate of the establishment, Mario Vargas Llosa. What the Peruvian case demonstrated was that, despite state-led industrialization's weak linkages with subaltern groups and despite neoliberalism's success at taming hyperinflation elsewhere, neoliberalism was not a politically palatable alternative. Despite its manifest failure, there was still support for state-led industrialization in Peru.

At the same time, Peru offers the worst case of the failure of ISI in Latin America. If we compare the effects of Peru's economic policies during the 1980's to its neighbours, the situation of Peru was clearly the most dire in South America. (See tables below.)

Even in comparison with its neighbours, Peru's economic record was a disaster. Inflation spiralled out of control for years so its cumulative effect on dislocating the economy was much greater. Only in Peru was hyperinflation matched with a hyper-recession. In Peru, real wages collapsed even further than elsewhere. Yet in Peru, where the case for reform was the strongest, neoliberal reforms resulted in the overthrow of democratic political structures and the 
establishment of an authoritarian dictatorship. This demonstrates that the ability to change through democratic means depends less on the clarity of the need for reform than the strength of its underlying organisations in civil society. When the system as a whole is overwhelmed by catastrophe and civil society collapses, then transformations can only be imposed through a Caesarist dictatorship.

Peru in Comparison.

GDP Percentage Growth per Capita

\begin{tabular}{|l|l|l|l|l|l|}
\hline Country $^{79}$ & 1980 & 1985 & 1987 & 1989 & 1990 \\
\hline Argentina & 3 & -9 & 2 & -9 & -3 \\
\hline Bolivia & -4 & -4 & 0 & 1 & 2 \\
\hline Chile & 7 & 5 & 5 & 9 & 2 \\
\hline Colombia & 2 & 1 & 3 & 1 & 4 \\
\hline Ecuador & 2 & 0 & -5 & -1 & 0 \\
\hline Peru & 0 & 1 & 6 & -13 & -7 \\
\hline
\end{tabular}
Inflation (Per Cent per Annum)

\begin{tabular}{|c|c|c|c|c|c|}
\hline Country & 1980 & 1985 & 1987 & 1989 & 1990 \\
\hline Argentina & 101 & 672 & 131 & 3080 & 2314 \\
\hline Bolivia & 47 & 11750 & 15 & 15 & 12 \\
\hline Chile & 35 & 28 & 30 & 76 & 49 \\
\hline Colombia & 27 & 24 & 23 & 26 & 29 \\
\hline Ecuador & 13 & 28 & 30 & 76 & 49 \\
\hline
\end{tabular}

79

These countries were chosen as the most comparable to Peru in Latin America. Both Mexico and Venezuela were large oil exporters. Brazil was a different order because of the size of its population. 


\begin{tabular}{|l|l|l|l|l|l|}
\hline Peru & 59 & 163 & 86 & 3399 & 7482 \\
\hline
\end{tabular}

\begin{tabular}{|l|l|l|l|}
\hline Country & Real Wages $1980=100^{80}$ & 1989 & 1990 \\
\hline & 1985 & 43.3 & 37.1 \\
\hline Peru & 79.3 & 80.6 & 77.9 \\
\hline Argentina & 96.3 & 69.2 & 73.6 \\
\hline Bolivia & 69.7 & 102.5 & 104.3 \\
\hline Chile & 92.7 & 122 & 122.5 \\
\hline Colombia & 116.2 & 44.6 & 40.1 \\
\hline Ecuador & 69.1 & & \\
\hline
\end{tabular}

But in other Latin American countries, structural adjustment did not lead to an interruption in their constitutional order. Nor did it result in the collapse of existing systems of representation. However, it is the contention of this thesis that the extreme nature of Peru's economic crisis merely exaggerated and made more explicit a shift in structures of representation. As noted earlier, the phenomena of neo-populism and delegation shifted resources away from channels of redistribution organised through political parties and into the hands of the president. Even when parties ostensibly survived, like the Peronist party under Menem, the content of their ideological discourse had changed so completely that one could ask whether or not it was the same party at all. ${ }^{81}$ Not

80

Roberto Patricio Korzeniewicz, "The Deepening Differentiation of States, Enterprises and Households in Latin America," in Politics, Social Change and Economic Restructuring in Latin America, ed. William C. Smith and Roberto Patricio Korzeniewicz (Coral Gables: North-South Center Press, 1997), 221. 81

Celia Szusterman, "Carlos Saul Menem: Variations on the Theme of Populism," Bulletin of Latin American Research 19 (2000), 199-200. 
only parties lost out, but legislatures also lost influence, ceased to perform their deliberative function and became as James Petras and Henry Veltmayer observed, "mere talking shops." ${ }^{82}$ Without effective political parties to aggregate demands or articulate alternatives to neoliberalism, the content of democracy was emptied as democratic debate was silenced. Instead of being able to exert political pressure through political parties and elections, citizens had to turn to extra-parliamentary opposition. The centralization of all power into the hands of the president insulated the state from popular pressures.

In Peru, Fujimori's centralization of power was only more explicit than elsewhere. The shift of power to the executive branch elsewhere mirrored the Caesarist shift that occurred in Peru, even if the survival of hollowed-out parties obscured a loss of democratic representation.

But while in Peru the transformation resulted in a dictatorship with a democratic facade, what was the effect on other Latin American countries? Once the transformation to neoliberalism was completed, what kind of democracy was left? As this thesis will demonstrate, it was a form of democracy that lacked the ability to ameliorate the excesses of capitalism by state action. This state was premised upon the renunciation of its duty to intervene in market outcomes, at least on behalf of subaltern classes. Citizens had the vote, but they could not use their votes to demand resources that could challenge the status quo. As the 82

Henry Veltmeyer, James Petras, and Steve Vieux, Neoliberalism and Class Conflict in Latin America: A Comparative Perspective on the Political Economy of Structural Adjustment (London: MacMillan Press Ltd., 1997), 68-69. 
scope of the state was circumscribed by neoliberalism, democratic political action through electoral politics ceased to offer the possibility of challenging the terms of domination. While mass protest movements against privatization have succeeded, they do so outside the formal political arena of elections. Thus, as the scope of electoral politics is limited, democracy is contained. The only difference in Peru was that the loss of citizens' power in democracy was more explicit.

The Peruvian case allows us to examine a conjuncture where a consensus around the direction of the future had broken down, where a consensus over normative values failed, where trust in politicians vanished and the "system" fell apart. Yet in this moment of change, transformation was simply more explicit and obvious than in other countries. In other countries, the crisis at the end of SLI based on state ownership was not as severe and thus not as obviously a crisis of accumulation in the economy. The Peruvian case was more explicit and extreme in the path it took toward transformation even though the end result was a changed state, relations of production and the shared ideological base Gramsci described as common sense.

\section{The Structure of the Argument}

Before the process of transformation can be assessed, the conjuncture of Peru in 1990 must first be understood in order to avoid ascribing changes to neoliberalism that in fact derived from the political conjuncture of Peru. In 
Chapter One the depths of the crisis Peru found itself in will be explored. The central work of this chapter is an examination of the causes of the death of stateled industrialization in Peru. Did structural adjustment overturn the old order based on state-led industrialization, or had it already imploded and bankrupted itself? Was Fujimori's job to dynamite a functional order for the IFI's or was it only to cart away the rubble of the old and impose a new structure?

But if Fujimori was faced with a vacuum and a failed system when he entered office, why did he turn to neoliberalism as the solution? What kind of order did neoliberalism offer? If ideology shapes an order, then the arguments and ideas its progenitors proposed would then be utilized to legitimate reforms imposed in Peru.

Chapter Two examines the ideological premises of neoliberalism's leading theorists, Milton Friedman and Friedrich Hayek, in order to assess the new order they proposed. Neoliberal policies have not led to unbridled economic success and they have led to increasing inequality. Yet these policies remain politically powerful. Structural affinity offers us a fruitful series of questions to explain the survival of neoliberalism. Instead of judging these policies for their effectiveness, structural affinity guides us to search for how these ideas materially and politically benefit key groups and actors and articulate their interests. The question is how did the ideas expressed by Friedman and Hayek then serve to legitimate the social relations of production characteristic of a neoliberal order? Whose interests were served by the adoption of these relations of production? These ideas also matter because they describe a particular form of the state, a 
state that then articulated and reproduced neoliberal relations of production.

While ideas help drive the process of transformation, changes still require agents to implement them in a contested political process. Chapter Three is an examination of the role Fujimori and the technocrats played in the implementation of neoliberal reforms. Understanding how and why they created change in turn leads to questions about what was it about neoliberalism and technocrats that lent itself to transformation. If there was an affinity between neoliberalism, neoliberals and authoritarians, then it must be possible to uncover a series of mutual supports between authoritarian actors and neoliberalism as an ideology.

While Chapter Two explores how an ideology might be useful, Chapter Three explores how Fujimori as a Caesarist dictator and a group of neoliberal technocrats were able to form a political alliance that was useful for both sides. This chapter will further develop the concept of a Caesarist dictatorship from Chapter One by focussing on how it served in the forced transformation towards neoliberalism. The chapter also seeks to prove that Fujimori personally preferred dictatorship, to dispel any illusions that Fujimori was driven to use authoritarian methods by political necessity.

While neoliberalism was useful for the establishment of an authoritarian regime, why did Fujimori pick neoliberal policy reforms? Indeed, Fujimori actively campaigned against the imposition of shock policies and neoliberalism before he was elected. The purpose of Chapter Four will be to analyse how pressure from the international financial institutions (IFI's) was crucial in the imposition of a 
structural adjustment program. Yet structural adjustment was not imposed without the efforts of Peruvian actors. Instead a curious alliance was struck between the IFl's and neoliberal technocrats. Yet as Chapter Three explains, these technocrats were not organically linked to productive forces or dominant classes in Peru. Instead their position is best explained by Gramsci's understanding of a cosmopolitan elite and a passive revolution. This theory offers an explanation of how a disconnected group of experts could be used to impose a new order from above and outside that society, yet firmly linked and dependent upon international forces. Thus this chapter is an examination of the process through which the IFI's imposed their preferences in a concrete political situation.

In order to test the thesis that transformations involve changes to the state, once the roles of ideas and agents have been explained then the changes implemented need to be explored. In Chapter Five the question is what kinds of economic changes were created by adopting neoliberal policies. Did changes to the role of the state also help transform the economy?

Chapter Five is a study of the effects of these reforms. This chapter is also an examination of who benefited from changes driven by SAP's. This chapter will examine the reforms imposed under the Washington Consensus to delineate just how much was changed in Peru. Did the reforms of the Washington Consensus taken as a whole, involve transforming the common sense, the relationship between society and the state, and the orientation of the economy? 
If a new order entails a new economic structure then change will also be reflected at the level of relations of production. Relations of production are not only reproduced by specific state institutions, they also generate their own independent patterns of interaction and institutions. These institutions have their own resources which can be mobilized in their own self defence. For state-led industrialization to be dissolved, its institutions must have been fatally compromised.

But did the transformation of the state result in changes in the social relations of production to the capillaries of power in the workplace? Did changes to the grand purposes of the state affect the balance of forces between classes? Were unions simply victims of a neoliberal state, or had contradictions internal to the particular history of the labour movement left it fatally weakened and vulnerable to neoliberal reforms? Chapter Six will examine these issues in order to discover the extent to which neoliberal reforms not only had an impact on the formation of the state but also on relations of production.

In this political conjuncture, the labour movement lost its historic veto over economic reform, a development which helped support the imposition of a new neoliberal order? As delineated in Chapter Two, neoliberal ideology was antithetical to unions and contained specific proposals to cripple their power. What this chapter demonstrates is how a vacuum at a political level led to the possibility of a Caesarist regime resolving an economic impasse by imposing a new labour code that established new social relations of production based on worker insecurity. 
Overall then, this thesis is a study of how in one situation, at one time, a new ideology facilitated the creation of a new state that then supported a new way of organising the economy. These changes were not limited to a slight reform of government policies, they entailed changing structures of representation, constitutions and labour codes. A change in the direction of the economy required the dismantling of all previous political institutions.

But before we can assess and understand how change was imposed, we must examine the failure of the previous order in Peru and the development project of state-led industrialization. The collapse of the economy and the political system in Peru is the subject of the first chapter. 


\section{Chapter One: Crisis and the Context of Change}

The context within which Fujimori first rose to power and then imposed a new order must be examined to understand the process of transformation. Fujimori's dictatorship was not driven by a desire to overthrow the previous order but instead responded to its failure. Fujimori did not topple the old regime, he merely presided over its funeral.

In order to understand the causes of chaos, this chapter will examine the triple crises in security, the economy and representation that overwhelmed the old order. But before these particular crises can be examined there will be a brief description of the social and political history of Peru, to put this particular crisis within its context of a recurring and indeed almost permanent crisis of domination. The crisis of security caused by the guerrilla campaign of Sendero Luminoso will be examined for the damage it did to the economy, to organisations in civil society, to relationships between the state and society and to the legitimacy of political parties. Next, the crisis in the economy will be analysed to show the political and social consequences of the failure of state-led industrialization. Hyperinflation not only personally bankrupted Peruvians, it also bankrupted their faith in the state, its economic model and the ideology that had legitimated this order. The twin crises of Sendero and hyperinflation then sparked a third crisis, a crisis in representation or a crisis of faith in all political leaders and parties. This chapter will illustrate how a crisis in representation was more than a rejection of individual political leaders, it was also a reflection of a 
structural crisis in the social relations of production and the regime of accumulation. This chapter will utilize Gramsci and Marx's theoretical insights into the rise of Napoleon III and Mussolini to offer an explanation of both the defenestration of Peru's political parties and the subsequent rise of Fujimori.

Within the argument of this thesis, this chapter is an examination of how the previous order was destroyed by its own internal contradictions. The state failed to protect its citizens, the economy had collapsed and no one trusted the political elites to govern. Within this context, Fujimori appeared as yet another man on a white horse who would save Peru from itself.

\section{Historical and Social Context: The Failure to Achieve Hegemony}

Within the history of Peru, the crisis of domination that resulted in the rise of Alberto Fujimori and his Caesarist dictatorship was hardly unique. A brief sketch of the political history of Peru reveals a recurrent pattern of the failure of Peru's elites to develop a stable historic bloc that could rule more through consent than coercion with legitimacy.

According to Antonio Gramsci, dominant classes achieve hegemony by creating a coalition of groups within which one class's values and interests predominate within an historic bloc. ${ }^{1}$ Hegemony is achieved when these values are successfully inculcated into the general population as common sense, as an

1

Antonio Gramsci, Selections from the Prison Notebooks of Antonio Gramsci, ed. and tr. Quintin Hoare and Geoffrey Nowell Smith, (New York: International Publishers, 1971), ff5, 56. 
unquestioned set of ideals. When an historic bloc is successful, rule is exercised more by consent than coercion and political institutions are stable. ${ }^{2}$

In Peru's history, political stability has been an elusive dream. From independence until 1985, no democratically elected president turned power over to a democratically elected successor. Instead, elected presidents had their terms cut short by coups followed by military governments which turned power back to civilians followed by yet another coup. The inability of either the officer corps or democratic leaders to create a stable political system was an indication of the absence of a dominant class able to impose its hegemony.

Underlying this instability was a society divided along ethnic, geographic and economic lines. Historically, Peru has had one of the world's greatest levels of income disparity. Since the conquest, opulent wealth for the few has been paid for by the starvation of the many. In the mid-1970's, Peru had one of the highest Gini coefficients in the world, while the trend from 1950 to 1980 was for an even greater level of income concentration. ${ }^{3}$ This obvious level of disparity between Peruvians was hardly an advertisement for the justice of the ruling elites.

One of the roots of division in Peruvian society was the complex division based on race. But unlike in the United States, where "any known blood" renders

${ }^{2}$ Gramsci, 276.

3

Aldolfo Figueroa, "Income Distribution and Inequality in Peru," in Fujimori's Peru: The Political Economy, ed. John Crabtree and Jim Thomas (London: Institute of Latin American Studies, 1998), 138. 
one a member of the black underclass, in Peru, race is a complex and elastic construction. As we have seen, membership in one of the major categories depends on linguistic profile, geographic location, and, underlying it all, class. In Peru the expression has always been that "money whitens ", or membership in one of the racial categories depends as much on one's socio-economic status as genetics or family background.

But despite a history of conflict between the city and the countryside, between the criollos and the indios, resistance has been expressed on national and class lines rather than primarily in ethnic terms. ${ }^{4}$ One of the reasons for this was that the traditional forms of domination and control had been dissolved by the land reforms of the Revolutionary Government of the Armed Forces (RGAF) of General Velasco (1968-1975). In the rural areas, the power of the landed oligarchy was broken through a land reform that turned the haciendas into cooperatives. ${ }^{5}$ The problem for these communities was a lack of integration into the national economy rather than an excess of exploitation.

In comparison to other Latin American nations with large indigenous populations, in Peru there has been a notable lack of political mobilization on

4

Rudolfo Stavenhagen, "Social Dimensions: Ethnicity," in Democracy in Latin America: (Re)Constructing Political Society, ed. Manuel Antonio M. Garreton and Edward (Tokyo: United Nations University Press, 2001), 176.

5 John Sheahan, Searching for a Better Society: The Peruvian Economy from 1950 (University Park Pennsylvania: Pennsylvania State University Press, 1999), 63-64. 
ethnic lines. ${ }^{6}$ Instead, almost all political organizing was based on class identities. ${ }^{7}$ In the end, as Deborah Yashar concluded, the lack of a national network has prevented political mobilization on the basis of indigenous identity. ${ }^{8}$ In the 1980 's there had been the beginnings of a national union of campesinos which might have offered a base for indigenous organization. But this movement was organized by militants from the IU, and hence subscribed to a clasista mindset. Also Yashar failed to take into account the devastation caused by Sendero to these rural unions which could have been the base for indio organization (see below). After Sendero, indeed after Fujimori and after neoliberal reforms, there were no organisations left in rural areas that transcended parochial boundaries that could act as a base for mobilization based on class interests or ethnic identity. In this case, the historic bloc maintained its control over the Sierra by keeping these communities isolated and atomized, and of course through the presence of the Armed Forces in its war with Sendero.

But if relations with the rural sector did not define this order prior to Fujimori, what set of relationships did? The dominant form that the state was organised to reproduce, the development project that formed its core mission, was state-led industrialization. This order began under the RGAF during the

Deborah J. Yashar, "Contesting Citizenship: Indigenous Movements and Democracy in Latin America," Comparative Politics, (October 1998), 26.

${ }^{7}$ Yashar, 27.

${ }^{8}$ Yashar, 38. 
presidency of General Velasco (1968-1975). The state attempted to escape dependency by promoting state-led industrialization through state owned enterprises (SOE). ${ }^{9}$ The government also used these SOEs to purchase political support through price subsidies for the popular sector, a subsidy regime that left the state sector incapable of generating the capital required for expansion. ${ }^{10}$ But the need for capital to finance the SOEs' expansion in turn led these enterprises to borrow from international creditors, and it was these debts which led Peru into a crisis. ${ }^{11}$ These SOEs and the economy went through a recurring and escalating series of crises - from the military government of Bermudez (19751980), to the democratic government of Fernando Belaúnde (1980-1985), until its final collapse under Alan García (1985-1990). Instead of expanding and absorbing a larger and larger portion of society within its relations of production, the industrial sector declined. This version of state-led industrialization did not result in development, it almost led to Peru's total collapse. But one disaster that cannot be blamed on the failure of this order was the onslaught of Sendero.

\section{The Crisis in Order: Sendero Luminoso and the Threat to Security "Mere anarchy is loosed upon the world,"}

During the 1980's and early 1990's, Peru faced an insurrection by a

9

Carol Wise, Reinventing the State: Economic Strategy and Institutional Change in Peru (Ann Arbour: University of Michigan Press, 2003), 82-83.

${ }^{10}$ Wise, Reinventing the State, 105.

${ }^{11}$ Wise, Reinventing the State, 105. 
terrifying Maoist guerrilla force, Sendero Luminoso. The cumulative effect of Sendero Luminoso's campaign was to corrode social bonds within Peruvian society and disrupt the relationship between Peruvians and their state, while inflicting enormous economic damage. Broad areas in the Sierra were turned into a war zone which led to a demographic shift towards the cities at a time when the cities were already incapable of providing municipal services. But while the effect of the depredations of Sendero was to disarticulate or disrupt all social bonds, was Sendero caused in turn by the underlying crisis in the state, the economy, and ideology?

While a definitive study of Sendero lies beyond the scope of this thesis, some observations can still be made about the relationship between the faults of state-led industrialization as an order and the rise of Sendero. The major flaw of the existing economic and state model of state-led industrialization was not that it had led to the super-exploitation of the peasantry of the Sierra. Instead its shortcoming was that it did not incorporate the Sierra into its relations of production, production cycles or consumption. Instead of the rural sector becoming transformed and absorbed by state-led industrialization, its relations of production remained unchanged. Instead of providing increased profits or a market, the rural sector provide a cheap labour pool (the Peruvian expression that conveys this is cholo barato or cheap mestizo labour), and a reserve for the reproduction of labour with the family plot back home providing subsistence agriculture to feed the next generation. Sendero was a reflection of the failure of 
SLI to absorb the rural sector.

Sendero's social base was composed of those young men and women who had been dislocated from their places in the old society. Sendero appealed to the educated youth of the Sierra, who had been alienated from the lives of their parents by their high school education, yet had no hope for more education or finding a place in the formal job market. To these youth, Sendero offered the hope of social mobility and power. ${ }^{12}$ Sendero's appeal to its own cadre was thus to those excluded not those who were exploited.

In the beginning, Sendero gained some support in rural areas because it offered to enforce a semblance of social order. It punished social crimes like adultery, alcoholism and vagrancy which threatened survival in these communities. ${ }^{13}$ Sendero also initially provided protection for peasants' property by punishing cattle rustling and robbery while also attacking individually corrupt police officers and some merchants who had exploited them. ${ }^{14}$ However, it must

12

Carlos Ivan Degregori, "Harvesting Storms: Peasant Rondas and the Defeat of Sendero Luminoso in Ayacucho, "in Shining and Other Paths: War and Society in Peru, 1980-1995, ed. Steve J. Stern (Durham: Duke University Press, 1998), 128-129.

13

Ponciano del Pino H., "Family, Culture and Revolution: Everyday Life with Sendero Luminoso," in Shining and Other Paths: War and Society in Peru, 19801995, ed. Steve J. Stern (Durham: Duke University Press, 1998), 161. In this economy, alcoholism and vagrancy both threatened the scarce resources required for survival of the family, while adultery threatened the family unit. Since production was based on a complex set of extended kin relationships, personal failings like these threatened the survival of the community. 14

Ponciano del Pino H., 161, 171. Latterly, Sendero ceased to provide order or 
be noted that police corruption was not coupled with systemic merchant exploitation like the old gamonal system based on debt peonage. The complaint was that there was no access to the formal justice system to resolve community disputes and fairly enforce contracts. For the most part, the fault of this state was not that it enforced local exploitation but that it was not present. Sendero moved into a vacuum where the state had failed to provide an effective and accessible justice system.

However while Sendero may not have sprung from within the contradictions and class relations of state-led industrialization, its tactics still undermined those social and political relations. By 1990, the guerrilla war of Sendero had become a real threat to the personal security of all Peruvians, a threat the state seemed incapable of defeating. Terror was Sendero's central tactic. In the cities, Sendero burned gigantic hammer and sickle-shaped bonfires on the hillsides to announce its presence and instill fear in the general population. ${ }^{15}$ It set off car bombs and blew up power lines to cause blackouts and to create a feeling of impending doom and chaos. Sendero also called armed strikes, days when all transport and economic activities were to cease. Those who failed to honour these strikes risked lethal retaliation by teams of assassins called annihilation squads. The squads did not merely assassinate,

security as their actions descended into arbitrary violence and terror. 15

Deborah Poole and Gerardo Renique, Peru: Time of Fear (London, Latin America Bureau, 1992), 89. 
they slit throats and crushed skulls. "In Senderista language, the point was 'to smash with a stone as if [destroying] a frog."' 16 Sendero also symbolically annihilated its victims by dynamiting corpses which prevented community burial, mourning rites as well as resurrection come judgement day. Yet Sendero did not randomly murder its victims. The slogan was "the party has a thousand eyes and a thousand ears". The party had secret informants everywhere and any act of resistance was gruesomely punished. ${ }^{17}$ But what Sendero actually punished was any act of grassroots leadership or activity that was not under its direction.

These grotesque and theatrical tactics were part of the political strategy of Sendero's founder and absolute and unquestioned leader, Abimael Guzman. His plan for conquering the cities was to decimate literally civil society - all the civilian organisations outside of the state. To Sendero, the world was divided into enemies and Sendero: either you fought alongside Sendero in the armed struggle or you were with the enemy. In its view, any organisation that was not controlled by Sendero was part of the diseased social order that had to be eradicated. As the pro-Senderista daily El Diario put it:

On the one side, [there is] the fascist government.... its right wing, centre, and left wing allies [and] on the other side, the PCP-SL, the working class, the peasantry ... There is no room for intermediate positions. Either you side with the people and its struggles or you side with the reaction and its repressive apparatus. ${ }^{18}$

\footnotetext{
${ }^{16}$ Degregori, "Harvesting Storms," 140.

${ }^{17}$ Degregori, "Harvesting Storms," 143.

${ }^{18}$ Poole and Renique, 2.
} 
Popular organisations, especially those organised by the poor for the poor, were to be eradicated as distractions from the armed struggle.

Sendero's practical strategy for Lima was to create a political vacuum by annihilating civil society in the pueblos jovenes or shanty towns. Guzman planned to take over the "iron belt of misery", the broad brown belt of shanty towns that had grown up around Lima, and from there to surround and to strangle the administrative and economic core of Peru. ${ }^{19}$ These shanty towns had grown up in response to the state's long term inability to deal with the explosive growth in population in the cities. The pueblos jovenes were self organised: services usually performed by the state like education, roads, soup kitchens, water, garbage and sewage collection were provided by self-organised grassroots groups which formed the core of civil society organisations. Sendero targeted the leadership of these organisations for eradication.

The process of annihilation began with the discrediting of the existing popular leadership. Local leaders were classified by the party as either enemies, salvageables or allies. Enemies were accused of being sell-outs and thieves who trafficked in the misery of the masses. These leaders received death threats and were the targets of Sendero's annihilation squads. Salvageables were subject to blackmail and pressured to compromise themselves by participating in Sendero projects. Allies were kept in line through intimidation. Those with the most

19

Jo Maire Burt, "Shining Path and the 'Decisive Battle' in Lima's Barriadas: The Case of Villa El Salvador" in Shining and Other Paths, ed. Steve J. Stern (Durham: Duke University Press, 1998) 269. 
experience and expertise were most likely to be labelled enemies and hence murdered by Sendero. ${ }^{20}$ But Sendero was not interested in taking over these organisations as fronts; instead, Sendero's goal was to create a political and social vacuum. Thus organisations Sendero attacked either disappeared or became paralysed with fear, and the experience of successful indigenous selfmanagement of development projects was destroyed. ${ }^{21}$

Sendero further exacerbated the crisis of the cities by creating a wave of refugees. By 1990 , the war in the Sierra had created 700,000 internal refugees, ${ }^{22}$ who lacked skills needed by the urban economy yet flooded into the shantytowns surrounding Lima. Thus, instead of offering a new supply of labour for an expanding industrial economy, the shift in population to the cities simply overwhelmed already overtaxed municipal services.

Sendero not only displaced parts of the rural population; it also sought to disrupt economic linkages between the countryside and cities. A strategic goal of Sendero was to create isolated zones within which it could build bases of support to supply its armed columns. Sendero's tactics included engaging in acts of sabotage and destruction, toppling transmission towers, destroying roads and

\footnotetext{
${ }^{20}$ Isabel Cordero, "Women in War", in Shining and Other Paths, 367.

${ }^{21}$ Poole and Renique, 296.

22

Carlos Behr Boloña, Cambio de Rumbo: El Programa Economico para los 90 Lima, $6^{\text {th }}$ ed. (Instituto de Economia de Libre Mercado, Lima, 1995), 5.
} 
bridges and blowing up railways. ${ }^{23}$ Sendero also eradicated development projects because of their "bourgeois contamination". Thus Sendero destroyed agricultural extension stations and cooperatives within their zones of operation, forcing the peasants to sell their livestock for slaughter and destroying the cooperative's equipment. ${ }^{24}$ Overall, Sendero caused $\$ 22$ billion in damage to infrastructure. ${ }^{25}$ Sendero's overall strategic goal was to eradicate all bourgeois infrastructure in order to cause the state to collapse.

In response to Sendero, the relationship between the state and society was militarized. By January 1989, 56 out of 189 provinces, comprising more than half of Peru's population, were under military rule. ${ }^{26}$ In these emergency zones, human rights were suspended. There was no freedom of assembly or movement. Inhabitants were subject to searches and seizures without warrant. Civilians could be detained indefinitely without the protection of habeas corpus, and, if formally charged, were tried by military courts. ${ }^{27}$ In the emergency zones, the military replaced local civilian authorities, taking over not only the functions of the police and judiciary, but also the administration, organisation and

\footnotetext{
${ }^{23}$ Poole and Renique, 61.

${ }^{24}$ Poole and Renique, 82.

${ }^{25}$ Boloña, Cambio de Rumbo, 5.

${ }^{26}$ Poole and Renique, 13.

27
}

Kenneth Roberts and Mark Peceny, "Human Rights and United States policy toward Peru," in The Peruvian Labyrinth, ed. Max Cameron and Philip Mauceri (University Park: Pennsylvania State Press, 1997), 195-196. 
implementation of executive programmes. Effectively, the local military commander replaced elected municipal leaders, thus reducing the space within which democratic, grassroots civil society could grow within the structures of the state. Even the self defence forces, the rondas campesinas, which were an expression of campesino self organisation, were subject to military control. The rondas were organised, sponsored and armed by the military, and subject to military orders. However, the greatest danger to democracy was the development of military impunity. Military personnel were not subject to civilian judicial authority, only to military courts that refused to prosecute human rights offenses. Without the protection of an effective, independent judiciary, civilians had no rights.

The political effect of Sendero's war was to delegitimate Peru's democratic leaders. Civilian governance was eroded by the extension of military rule in the emergency zones which reduced the sphere of democratic rule. Sabotage sapped an economy already in crisis. The state could not protect either grassroots leaders in civil society or Peruvians in general from Sendero. Overall, the security crisis created a sense that none of the democratic political leaders were capable of defending Peru against the anarchy let loose by Sendero.

\section{The Economic Crisis}

Whatever damage Sendero caused to the economy and social and 
political structures, the damage to society caused by the collapse in the economy was even greater. The economic crisis effectively destroyed all civil society organisations that had grown up within the previous order. By making previous patterns of interaction meaningless or nonsensical, the collapse of the system disarticulated all social relations.

The collapse of this kind of state-led industrialization happened under the government of President Alan García (1985-1990), the new leader of APRA (Alianza Popular Revolucionaria Americana, Popular Revolutionary Alliance of the Americas), a populist party that had been Peru's largest party since the 1930 's. ${ }^{28}$ García proposed economic populist solutions to Peru's problems, a policy he described as "progressive social reactivation. "Populism, as an economic policy in this case, refers to a policy of using state intervention to increase income levels amongst the popular classes and hence increase demand. While demand is increased, the underlying relations of production and ownership are not challenged. Social relations of production were not challenged or changed to become more efficient as was the case with the Taylorization of work processes under Fordism. ${ }^{29}$

Despite cuts in taxes and increases in subsidies, there were no

28

APRA had the only mass membership of any Peruvian political party and it had organized its own clubs, restaurants, barber shops, trade unions and even schools. Poole and Renique, 107-108.

29

Alain Lipietz, Mirages and Miracles: The Crises of Global Fordism (London: Verso, 1987), 35. 
mandatory measures designed to force the bourgeoisie to reduce their own consumption and increase investment. Thus an increase in demand was not met by an increase in productivity with the result there was a short-lived populist boom followed by an inflationary and recessionary bust. ${ }^{30}$.

While this economic strategy resulted in disaster, the alternatives attempted by his predecessor Belaúnde were hardly a resounding success. Belaúnde had attempted to shift the economy back into primary goods development, but a collapse in primary goods prices and the monetary interest rate shocks of the early 1980's resulted in Peru falling into arrears to the IFIs by 1984 and succumbing to an economic crisis (see Chapter Four and Six for details). Thus García faced a pre-existing crisis of accumulation that neoliberal austerity measures had failed to resolve. Considering that the solution of the IFIs was to slash social spending when Peruvians were going hungry, they offered no reasonable solution either.

García's economic platform was based on a mandatory increase in real wages to expand domestic demand and hence utilize Peru's productive capacity and reactivate the economy. ${ }^{31}$ Prices were frozen, the exchange rate was

30

For a fuller discussion of economic populism, see Macroeconomic Populism in Latin America, ed. Rudiger Dornbusch and Sebastian Edwards (Chicago: University of Chicago Press, 1991).

31

Peter Flindell Klaren, Peru: Society and Nationhood in the Andes (New York: Oxford University Press, 2000), 387. 
reduced and then fixed, and interest rates were slashed.$^{32}$ APRA attempted to purchase the support of the bourgeoisie through a combination of tax cuts and investment subsidies which totalled US $\$ 15$ billion. ${ }^{33}$ In part to finance this reactivation through government spending, García also proposed to limit external debt repayments to only $10 \%$ of Peru's foreign exchange earnings.

The unfortunate result of this policy was an international credit strike, with the World Bank, Inter-American Bank and the IMF all suspending credits to Peru while private banks cut off commercial credit for trade ${ }^{34}$ No matter how many hardships Peruvians faced, no matter how dire the economic crisis, the IFIs demanded repayment before all else. Banished from the international banking system, Peru ran out of foreign exchange reserves, and by 1988 Peru was faced with a shortfall of US $\$ 275$ million $^{35}$. The Peruvian government had to resort to buying needed foreign exchange from regional banks, dollars that were derived from the cocaine trade. ${ }^{36}$

Then in 1987 García attempted to nationalize the banks, in part to deal with capital flight. Nationalization was conducted without warning which private

32

Carol Wise, Reinventing the State: Economic Strategy and Institutional Change in Peru (Ann Arbour: The University of Michigan Press, 2003), 160.

33

Teivo Teivanen, Enter Economism: Exit Politics: Experts, Economic Policy and the Damage to Democracy (London: Zed Books Limited, 2002), 72.

${ }^{34}$ Poole and Renique, 128-129.

${ }^{35}$ Poole and Renique, 129.

${ }^{36}$ Wise, Reinventing the State, 160. 
capital thought of as a declaration of war. Instead of investing in productive enterprises, those who had an income or access to capital sought to protect themselves by converting everything into American dollars on the black market as a desperate hedge against hyperinflation. The survival strategy for the elites became to speculate in foreign currencies which replaced both the consumption of domestic goods and investment in either inventory or capital assets. A reduction in consumption and inventory depressed domestic demand for Peruvian consumer goods and led to further reductions in production and inventory. ${ }^{37}$

The negative international conjuncture together with Garcia's economic populism led to a lethal combination of hyperinflation and depression that by 1990 had ravaged Peru. Between 1985 and 1990, the cumulative inflation was 2.2 million percent. $^{38}$ In 1990 alone, the inflation rate was $7850 \% .{ }^{39}$ Hyperinflation did more than create inconvenience. It destroyed economic linkages throughout the economy. Hyperinflation deformed all economic exchanges, as sellers sought pre-emptive inflationary increases in an attempt to cover their replacement costs. The private sector ran down inventories and shut down

Daniel M. Schydlowsky, "The Peruvian Economy Circa 1990: Structure and Consequences," in The Peruvian Economy and Structural Adjustment: Past Present and Future, ed. Efrain Gonzales de Olarte (Miami: North South Center Press, 1996), 104.

${ }^{38}$ Boloña, Cambio de Rumbo, 6.

${ }^{39}$ Poole and Renique, 23. 
production. In a last ditch attempt to reduce inflationary pressures, García slashed state expenditures, which only further reduced demand and pushed the economy into a deep recession. The economy shrank by $8.3 \%$ in $1987-1988$, by $11.7 \%$ in $1988-1989$ and by $5.1 \%$ in $1989-1990 .^{40}$ Per capita income fell to the level of $1960 .{ }^{41}$ Peru faced economic collapse.

The decline in the economy drove the bourgeoisie into the informal economy of the ambulantes (street pedlars) and sub-legal enterprises. By entering the underground or informal economy, private enterprises could avoid taxes, especially the general sales tax, the Impuesto General a las Ventas (IGV). The major advantage for the bourgeoisie of entering the informal sector was that they could shrink their labour costs through paying less than the minimum wage, refusing to pay benefit packages mandated through the comunidad laboral, and then let workers go when business slowed down. Competition from firms that had fled to the informal sector drove businesses into the underground to survive.

But not only business was driven underground, workers were also lured into the informal economy for survival, as real wages declined by $35 \%$ from 1985 to $1990 .{ }^{42}$ Wages were first eroded by hyperinflation and then by the

40

Shane Hunt, "The Current Situation in Long Term Perspective" in The Peruvian Economy and Structural Adjustment: Past Present and Future, ed Efraín Gonzales de Olarte (Miami, North South Institute, 1996), 30.

${ }^{41}$ Boloña, Cambio de Rumbo, 6.

42

Javier Iguiñiz Echeverría, "The Difficult Moments of the Fujimori Economic Strategy" in The Peruvian Economy and Structural Adjustment: Past Present and Future, ed. Efraín Gonzales de Olarte (Miami: North South Institute, 1996), 267. 
government's attempts to restrain wages to reduce inflationary pressures and control its deficit. By 1990 , only $18.6 \%$ of the population had a monthly income above the poverty line, down from $60 \%$ in $1987 .{ }^{43}$ Workers sought severance payments to finance startups in the informal economy as independent business persons trading as ambulantes, the ubiquitous street peddlers of Lima.

The economic collapse under García drove most Peruvians into poverty. Consumption expenditures in Metropolitan Lima, including food, dropped by $46 \%$ between 1986 and $1990 .{ }^{44}$ To survive, poor Peruvians turned towards comedores populares, the locally organised neighbourhood soup kitchens organised by the poor themselves to provide at least one nutritious meal a day. Ultimately 1.2 million Peruvians came to rely on these kitchens daily. ${ }^{45}$ Yet despite the growth of soup kitchens and the vaso de leche programs (cooperatives which sought to give children a daily glass of milk), malnutrition became commonplace: by $19905,753,600$ of 22 million Peruvians, or $26 \%$ of the population, suffered from chronic malnutrition. ${ }^{46}$ The populist promises of Alan García had led to hunger for Peruvians.

The state also starved during the crisis. The combination of hyperinflation, recession and the growth of the informal economy drastically eroded state

\footnotetext{
${ }^{43}$ Iguíñiz Echeverría, 267.

${ }^{44}$ Burt, 270.

${ }^{45}$ Coral Cordero, 365.

${ }^{46}$ Deborah Poole and Gerardo Renique, Peru: Time of Fear, 23.
} 
revenues. By the time taxes were collected from intermediaries (like enterprises withholding income taxes or consumption levies), the real value of those taxes were reduced by the rate of inflation. The recession also reduced the tax base as taxable economic activity slowed. The growth of the informal economy meant that economic actors avoided social security payments and consumption taxes. ${ }^{47}$ Revenues declined from $15.6 \%$ of GDP in 1980 to $13.2 \%$ in 1985 to $5.8 \%$ by 1990 , and $4.9 \%$ in the first half of $1991 .^{48}$ This resulted in a massive fiscal deficit which grew to $16 \%$ of GDP, a deficit which was covered by printing money, ${ }^{49}$ which sparked even more hyperinflation.

But hyperinflation combined with price controls on government-supplied goods and services and multiple exchange rates distorted relative prices. Imported food and medicines were subsidized through special exchange rates, but special exchange rates produced cheap dollars that became a source of corruption. Prices for fuel and some basic government services were subject to price controls. ${ }^{50}$ Skewed relative prices twisted economic actions which were designed to take advantage of subsidized commodities and especially sought to gain subsidized access to dollars. Economic activity became centred on the

\footnotetext{
${ }^{47}$ Schydlowsky, 116.
}

48

Rosemary Thorp and Francisco Durand, "Tax Reform the Sunat Experience," in Fujimori's Peru: The Political Economy, ed. John Crabtree and Jim Thomas (London: Institute of Latin American Studies, 1998), 212.

${ }^{49}$ Boloña, Cambio de Rumbo, 16.

${ }^{50}$ Schydlowsky, 107. 
fiddle and the scam, not on production for a stable market.

One of the ways the García government sought to reduce both inflationary pressures and the fiscal deficit was to reduce the real wages of Peruvian civil servants. By letting wages fall behind the rate of inflation, the government hoped that costs would be reduced and demand lessened. Thus in 1987, wages in the public sector fell to $69 \%$ of their value in 1979 , and then as the government tried to reduce its deficit, in the space of one year they dropped even further to $28 \%$ of their 1979 value in $1988 . .^{51}$ In comparison, private sector wages for white collar workers were $109 \%$ in 1987 , and $60 \%$ of their 1979 value in $1988 .{ }^{52}$ Even blue collar workers fared better than the civil service, with wages that declined to $91 \%$ in 1987 , and then $46 \%$ by 1988 of their 1979 wage levels. ${ }^{53}$ García sacrificed the civil service in the fight against hyperinflation.

The survival strategy for civil servants became corruption. Faced with personal destitution because of vanishing wages, Peruvian civil servants first turned to second jobs to supplement their wages. Supervisors in the civil service were well aware that the state no longer paid a living wage, and became tolerant of employees putting in short working hours so that they could moonlight at other activities to survive ${ }^{54}$ Furthermore, García's heterodox economic policies

51

Henry Dietz, Urban Poverty, Political Participation and the State: Lima 19701990 (Pittsburgh: University of Pittsburgh Press, 1998), 58.

${ }^{52}$ Dietz, 58.

${ }^{53}$ Dietz, 58.

${ }^{54}$ Schydlowsky, 113. 
involved massive amounts of new regulations, permits and licences. Civil servants extracted a living wage by demanding bribes for these lucrative licences and permits. ${ }^{55}$ With absentee workers and widespread corruption, the state was incapable of effectively administering its own policies. Peruvians came to regard the state as a threat to their survival and a source of their problems rather than a useful interlocutor in their lives that could provide services.

Corruption also caused a decline in the legitimacy of the police forces. Hyperinflation and hyper-recession created a rise in crime and delinquency that the police utterly failed to control. Instead, there were numerous cases of police involvement in violent crimes, including armed assaults, kidnapping and extortion. There were numerous confrontations between citizens and the police as public respect deteriorated. ${ }^{56}$

While corruption corroded the legitimacy of the state, cutbacks erased the salience of the state for the poor of Peru. By 1990, some three to three and a half million limeneos (residents of Lima), half of the population of Lima, up from a third in 1981, lived in the pueblos jovenes. ${ }^{57}$ These neighbourhoods were formed by self-organised mass land invasions which the state had passively encouraged to deal with housing shortages. They lacked standard municipal services normally provided by the state: electricity, water, sewers, garbage pickup, police,

\footnotetext{
${ }^{55}$ Schydlowsky, 113.

${ }^{56}$ Burt, 271.

${ }^{57}$ Burt, 270-271.
} 
roads, health care facilities, schools, and public transit facilities. The pattern had been that, over time, with self help and through political pressure on the state, these services would be gradually extended into the pueblos jovenes. However, by 1990 , the bankruptcy of the state had led to a decline in spending on social services, from 4.61 percent of GDP in 1980 to 1.78 percent in $1991,{ }^{58}$ and spending on education lost $75 \%$ of its value from 1986 to $1990 .^{59}$ By 1990 , the state's bankruptcy meant that it was clearly incapable of extending core services to the pueblos jovenes.

The political result of the bankruptcy of the state was the sundering of previous patterns of the pobladores' (the poor's) relationship to the state. Previously, pobladores had two central strategies for extracting services from the state, what Susan Stokes has described as clientelism and radicalism. ${ }^{60}$ Clientelist leaders spent time attempting to nurture patron-client ties with particular members of Peru's bureaucracy. In these cases, aid from the government was seen as the result of personal charity by individual officials whose generosity was carefully nurtured through deference and flattery. ${ }^{61}$ Clientelist leaders derived their authority from their ability to communicate

\footnotetext{
${ }^{58}$ Burt, 300-301.

${ }^{59}$ Burt, 300-301.
}

60

Susan Stokes, Cultures in Conflict: Social Movements and the State in Peru (Berkeley, University of California Press, 1995), 30.

61

One helpful official was rewarded for providing maps of the community by having the central street in Las Flores named after him. Stokes, 30. 
effectively with bureaucrats and their personal connections to officials. ${ }^{62}$

In contrast, the radicals' strategy was based on embarrassing the state into delivering services. Confrontation rather than conciliation generated results through hard bargaining with officials. But both strategies presumed that the state had resources to distribute, which, by 1990 , it clearly no longer had. As Henry Dietz noted, "Lima's poor found themselves caught in a situation where petitioning the state became an exercise in futility." ${ }^{63}$

The collapse of the state left the pobladores in a difficult situation. On the one hand, they recognized that development required state help: in 1990 two thirds of pobladores believed that the government was best suited to solving their neighbourhood's most pressing needs, while only $20 \%$ thought they could do it themselves. ${ }^{64}$ But the economic crisis had bankrupted the state which in turn broke patron-client ties between the state and poor communities. The radical strategy of using protests to garner resources was a waste of time. Furthermore, protest required public activity, activity which identified participants to both the repressive apparatus of the state and to Sendero. For individuals, political participation was both suicidal and an exercise in futility. The style of state-citizen interaction that characterized state-led industrialization had failed.

State-led industrialization as an economic system also finally collapsed

\footnotetext{
${ }^{62}$ Stokes, 78.

${ }^{63}$ Dietz, 177.

${ }^{64}$ Dietz, 183.
} 
under Garcia. The economic crisis was not merely a short term correction. Instead it marked what Alain Lipietz has described as the exhaustion of the potential of a regime of accumulation. ${ }^{65}$ The economy had suffered from recurring economic crises that had undermined successive governments from Belaúnde to Velasco to Bermúdez to Belaúnde again. García's failure was simply the most catastrophic. ${ }^{66} \mathrm{~A}$ continuation of state-led industrialization had not merely led to an impasse in development, it had led to the abyss.

Does the recurring series of crises that beset this economic model mean that any attempt at state-led and owned industrialization was inherently doomed to failure? At this particular conjuncture it would have been difficult to say the least. Class hostility and distrust prevented any attempt to find a corporatist compromise or concertation that could restrain wages and profits to create capital. Peru lacked a disciplined and ascetic national bourgeoisie that would reinvest its profits in improving productivity instead of simply increasing exploitation. A bourgeoisie addicted to using the state to guarantee its power and profits hardly made for a trustworthy bargaining partner with labour. Yet its labour unions had also adopted a confrontational and clasista stance which made any attempt at the state mediating a true wage and reform package based on concertatión almost impossible (see Chapter Six).

But while domestic political constraints made concertatión extremely

\footnotetext{
${ }^{65}$ Lipietz, 34.

${ }^{66}$ See Klaren and Sheahan for the best accounts.
} 
difficult, the actions of the IFIs guaranteed failure. The credit blockade of the IFIs escalated the crisis caused by the exhaustion of state-led and owned industrialization to the point where the crisis nearly broke Peru. To insist that all arrears be cleared and the entire debt must be honoured as a precondition for Peru's access to credit meant that García's experiment was doomed from the beginning. A credit strike depressed trade at the very moment when García needed increased capital inflows to reactivate Peru's economy. The anti economic populist stance taken by the IFIs and the punishment they exacted thus created a self-fulfilling prophecy of economic disaster.

The economic crises then sparked a political crisis and destroyed the legitimacy of the state. On the micro level, the crisis disarticulated painfully constructed links between the state and society. Without resources to reward patron-client ties or to placate protest, the state could no longer buy legitimacy or engage in, what Habermas terms, legitimation ${ }^{67}$. The military crisis terrorized Peruvians, but the economic catastrophe delegitimated the status quo.

\section{The Death of the Parties: The Political Crisis and the Rise of Alberto Fujimori}

By 1990 the security and economic crises led to a third crisis, a public crisis of confidence in every major political party and coalition. For different reasons, each of the parties were discredited by the failure of the state to defeat Sendero, by the calamitous economic situation and by the racial and class

\footnotetext{
${ }^{67}$ Jurgen Habermas, Legitimation Crisis (London: Heineman, 1976), 13.
} 
divisions of Peru. The result of this crisis in confidence was that instead of turning to traditional leaders, Peruvians turned instead to a political outsider, Alberto Fujimori.

The catastrophic failure of Alan García's government alienated key sectors and discredited APRA. García's original economic plan during the election of 1985 had been to call for a concertación, a social democratic coalition built on peak bargaining between business and labour and a reactivation of demand from the informal sector to provide a market for Peru's domestic production. ${ }^{68}$ Support for Garcia from the bourgeoisie had been led by the "Twelve Apostles", the twelve largest conglomerates which controlled business monopolies, industry and private finance.$^{69}$ However, García lost their support through his attempt to force private businesses to purchase compulsory state investment bonds in April 1987 to reduce his deficit and then finally by Garcia's surprise attempt to nationalize all banks in July. ${ }^{70}$ Concertación was replaced by a declaration of class war on capital as García betrayed the very conglomerates who had supported him.

García also alienated the labour movement, by first promising to consult them and then abandoning their members to the ravages of hyperinflation.

68

Maxwell A. Cameron, Democracy and Authoritarianism: Political Coalitions and Social Change (New York: St. Martin's Press, 1994), 45.

${ }^{69}$ Teivanen, 86.

${ }^{70}$ Poole and Renique, 129-130 
Originally, labour leaders had supported García's populist plans to reignite Peru's economy by stimulating demand. But, as we have seen, hyperinflation slashed the real value of their wages and salaries. In response to declining incomes, the CGTP (Confederación General de Trabajadores del Perú, Peru's largest labour confederation) led a paro, a national strike, to call for wage increases to match the rising cost of living. They also called for a true concertación, a real deal between industry, government and labour over economic policy. In order to strengthen the relative power of unions compared to capital, they demanded that labour stability laws be respected and that smaller enterprises be subject to collective bargaining. ${ }^{71}$ Instead, Garcia abandoned workers to hyperinflation.

Clientelism and corruption also offended the poor. In the pueblos jovenes, García tried to combat poverty through emergency assistance programs. The Programa de Apoyo Directo (PAD; Program of Direct Support) was supposed to assist and organise the activities of grassroots self-help organisation like the comedores populares. But instead of supporting pre-existing local grassroots organisations, PAD insisted that its local leaders be APRA sympathizers so that APRA could control the distribution of aid. ${ }^{72}$ Previously, the poor had participated in alleviating their own poverty through their own efforts under their own control and power in their own grassroots organizations. Instead of nurturing pre-existing organisations that encouraged participation, APRA used patronage

\footnotetext{
${ }^{71}$ Poole and Renique, 129.

${ }^{72}$ Dietz, 179.
} 
to eliminate the competition.

An APRA program designed to alleviate unemployment, the Programa de Apoyo de Ingreso Temporal (PAIT; Program of Temporary Income Support) was even worse. This program hired the unemployed at minimum wages to work on infrastructure programs in the pueblos. But the work was only temporary and hence did not solve the problem of unemployment. Furthermore, projects undertaken tended to be useless exercises in vanity, like Olympic-sized swimming pools without water or high tech centres without equipment. ${ }^{73}$ The PAIT bureaucracy was staffed by APRA party loyalists and ignored elected municipal leaders who tended to support IU (Izquierda Unida, the United Left coalition of political parties). In addition, PAIT projects were imposed on communities without consultation. ${ }^{74}$ After all, the purpose of PAIT was to generate loyalty to APRA by giving jobs to supporters. Participants in PAIT were bused to attend party rallies, and were even used to confront strikers with counter-demonstrations against picket lines. $^{75}$

At a time when the economic crisis threatened the very survival of the poor, patronage-driven demands for paeans to the glory of Garcia would have been galling to say the least. As one resident of the pueblos jovenes said: ".... the people running PAIT always talked about how wonderful García was and how

\footnotetext{
${ }^{73}$ Dietz, 180.

${ }^{74}$ Dietz, $179-180$

${ }^{75}$ Cameron, Democracy and Authoritarianism in Peru, 47-48.
} 
wonderful his government was. We heard that crap all the time. ${ }^{.76}$ García insulted the poor while his economic policies impoverished them.

Whoever wasn't directly attacked by García's seemingly erratic economic policies were beggared by the collapse of the economy. To be fair, his attempt to reignite the economy does seem to have run headlong into its own natural contradictions. Sanctions by the IFIs for his debt strike meant that there was going to be no international capital infusion. Without help, there were no resources left to pay for tax incentives and subsidies for investment, which forced García first to try to control capital and then latterly to control capital flight by nationalizing the banks. Faced with an escalating deficit, montetary emissions skyrocketed which resulted in hyperinflation. Since the state could not defend anyone against the ravages of hyperinflation, all suffered. In response to hyperinflation, García tried restraining government wages, only to have the civil service turn to corruption for their own survival. Whether or not it might have been possible to attempt a heterodox solution, the result of this attempt was an economic disaster.

By 1990, APRA and García were discredited as a political force. They had failed to defeat Sendero and bankrupted the economy. He packed the bureaucracy with his supporters, whose corruption was legendary even by Peruvian standards. By 1990, APRA was not an option.

However, by 1990, a turn to the left through an intensified use of the state

\footnotetext{
${ }^{76}$ Dietz, 180.
} 
was also discredited. The Izquierda Unida -IU (the United Left) destroyed its own reputation by indulging in internal factional fighting. To be fair, some of the IU's problems stemmed from its own internal contradictions. The IU was a coalition of communist parties, and, as communists, there was a contradiction between working towards a revolution and seeking victory through elections.

This inherent contradiction was brought painfully to light in the IU's attitude towards Sendero Luminoso. Sendero was attempting to bring down the bourgeois state and bring about the left's longed-for revolution. Thus, at first, IU activists sympathized with Sendero, even if they thought the tactics and goals of the Senderistas were misguided. But, as they became the primary targets of Sendero's assassination squads, some shifted to outright opposition to Sendero, and some were even willing to ally themselves with the military to defeat Sendero. PUM (Partido Unido Mariátegui, the largest party within the IU) split into two factions, the libios, (the Libyans) who wanted to start their own guerrilla front, and the zorros (the foxes) who thought Sendero would only lead to the defeat and repression of popular forces and hence wanted to join an anti terrorist front. The libios won and the zorros left. However, the attempt to start a guerrilla front was a failure, and PUM-supported peasant confederations collapsed under the onslaught of Sendero. ${ }^{77}$

At the national level, the IU disintegrated over the question of who would

77 Jose Luis Renique, "Apogee and Crisis of a "Third Path" in Shining and Other Paths, ed. Steve J. Stern (Durham, Duke University Press, 1998), 321-322. 
be their Presidential candidate in $1990 .{ }^{78}$ The left's penchant for internal faction fighting at a time when Peru faced its worse crisis since the War of the Pacific was a complete abdication of responsibility. ${ }^{79}$ Instead of offering a united alternative policy either to bankrupt populism or the savage capitalism of neoliberalism, the left dissolved in petty bickering. The political result was that the informal sector rejected the IU. In a survey of how the pobladores voted in 1990 that was conducted by Eliana Chavez O'Brien, responses reflected the belief that " the Left does not represent us; they only represent the personal interests of politicians and intellectuals; they divide and they do not explain the division." ${ }^{" 80}$ One of the leaders of a soup kitchen spoke eloquently of this divorce between the leaders of the IU and the reality of those whom they claimed to represent:

The Left is the only party that is concerned with the people, but they are selfish. They are concerned with their partisan interests and not those of all the people. Too often they talk from above but they don't live among us. They do not experience the lack of water, electricity, or mothers who go to the market and cannot afford to buy food for their

78

See Maxwell A. Cameron, Democracy and Authoritarianism, Chapter 5 for an account of the division of IU. Whether or not Cameron's game theory approach to explaining the rationality of the breakdown of IU is correct or useful, the irresponsibility of the left engaging in byzantine manoeuvring for position when their supporters were starving cannot be denied.

79

The War of the Pacific (1879-1884) resulted in the loss of valuable nitrate reserves, the occupation of Lima and the destruction of the Peruvian state and economy. (See David P. Werlich, Peru: A Short History (Carbondale, Illinois: Southern Illinois University Press, 1978), chapter 5.

${ }^{80}$ Cameron, Democracy and Authoritarianism, 120-121. 
children. $^{81}$

In addition, the entire discourse of the Marxist left was de-legitimated by the experience of war. In the aftermath of Sendero, Peruvians longed for peace and tranquillity. Talk of class oppression and struggle was regarded as the language of hatred and social resentment, a resentment blamed for civil war. To speak the language of the left did not evoke feelings of solidarity or a desire for justice; this discourse merely evoked memories of the terror of Sendero. Even in 1995 , survey results indicated that to be associated with the Left was still the political kiss of death. As Patricia Oliart explained: "Fear of returning to the years of war, combined with the failure of the most radical currents in politics and in the ability to represent popular aspirations, made the Left appear as a potential threat to the peace that had been achieved." 82

Consumed by internal wrangling, silent about Sendero, the left abandoned el pueblo and el pueblo rejected the left. Thus the masses were left without legitimate, trusted political agents who could represent their interests. They became politically available to the appeal of an independent caudillo, Alberto Fujimori.

Not only did the left lose the support of el pueblo, but the parties of the right also had their own problems of credibility. After García's attack on the

\footnotetext{
${ }^{81}$ Burt, 304.
}

82

Patricia Oliart, "Alberto Fujimori:'The Man Peru Needed?'" in Shining and Other Paths, ed. Steven J. Stern (Durham: Duke University Press, 1998), 422-423. 
banks, the bourgeoisie had united under the leadership of the internationally renowned writer Mario Vargas Llosa who led a new neoliberal political party Libertad (Liberty), and a right wing coalition FREDEMO (Frente Democrático, Democratic Front).

The problem was that FREDEMO included both AP (Acción Popular) and PPC (Partido Popular Cristiano, Christian Popular Party), traditional parties of the right that had governed Peru from 1980-1985 under President Belaúnde. They were as discredited as the left and the populist centre. The political elites of AP and the PPC, were heartily loathed as representatives of the corrupt old white oligarchy. Both Belaúnde and García were guilty of padding state employment in order to reward their followers, as the following table shows:

Employment in Peru's State Sector ${ }^{83}$

\begin{tabular}{|l|l|l|l|l|}
\hline Sector & 1982 & 1985 & 1986 & 1990 \\
\hline $\begin{array}{l}\text { General } \\
\text { Government }\end{array}$ & 495,649 & 614,837 & 713,065 & 730,000 \\
\hline Central Government & 385,523 & 493,530 & 558,669 & 561,000 \\
\hline $\begin{array}{l}\text { State } \\
\text { Enterprises }\end{array}$ & 107,742 & 142,953 & 172,000 & 172,000 \\
\hline Totals & 603,391 & 757,790 & 885,065 & 902,000 \\
\hline
\end{tabular}

Party adherents received jobs, at a time when the state was incapable of delivering services. In the middle of an economic crisis under Belaúnde,

${ }^{83}$ Schydlowsky, 112. 
employment increased by 150,000 , while APRA loyalists were equally rewarded under García. Small wonder that a commonly expressed view in 1990 was that "the pitucos (the rich white snobs) from AP want to steal from us again." ${ }^{84}$. Belaúnde's government had also failed to defend Peru against Sendero or to manage the economy which suffered from recession and high inflation by the end of his government. The traditional right wing parties AP and PPC engendered distrust, disgust and disrespect, not support.

As the candidate of the neoliberal right, Vargas Llosa also fell prey to the complex racial politics of Peru. Vargas Llosa was a member of Peru's white criollo elite and had spent most of his life in exile in Paris. During the election campaign, he committed a series of political gaffes that offended the cholo majority of Peru. For example, during the second round of the 1990 election, it was revealed that the supporters posing as ambulantes in his commercials were in fact the maids, chauffeurs and servants of his rich white neighbours and relatives. The commercial pretending to be set in a pueblo joven was actually filmed in his garden. ${ }^{85}$ Even Vargas Llosa's formal use of language reproduced the old exclusionary style of the criollo elites, and hence excluded the aspiration of the cholos for inclusion into the elites. ${ }^{86}$

In a situation where Vargas Llosa had already managed to irritate ethnic

\footnotetext{
${ }^{84}$ Cameron, Democracy and Authoritarianism, 61.

${ }^{85}$ Poole and Renique, 147-148.

${ }^{86}$ Oliart, "The Man Peru Needed?," 415.
} 
and class tensions, he proposed an unpopular radical shift to neoliberal policies. In a time of catastrophic crisis he proposed to gut the state, eliminate all consumption subsidies and eliminate job tenure rights and cost of living clauses. Neoliberal policies were not a popular or vote-winning choice. No wonder Peruvians turned to anyone other than this representative of the bourgeoisie.

Thus, by 1990, all politicians and political parties were loathed by Peruvians. Beláunde and García had led Peru into catastrophe while their supporters feathered their own nests. The campesinos of the highlands rejected all politicians as corrupt and abandoned the old political ways of participating in politics through marches, strikes, mass protests or voting. ${ }^{87}$ When traditional politicians offered nothing, the electorate became cynical and would vote for anyone who was independent from the old elites who had led Peru into a catastrophe. A British political consultant to Vargas Llosa, Mark Malloch Brown, had suggested that Vargas Llosa cut all ties to the traditional parties:

Popular Action and Christian Popular Party stood for all that was worse in our traditional political order...Peruvians held these parties and their leaders responsible, along with Garcia, for the national collapse. Mario failed to see that the anti-political tide that had carried him forward, was aimed as much as at the dinosaurs of the old right as his nemesis Alan García, the popular left. ${ }^{88}$

Peruvians not only rejected individual politicians for their incompetence and

Orin Starn, "Villagers at Arms: War and Counter-Revolution in the Central-South Andes," in Shining and Other Paths, ed. Steve J. Stern (Durham: Duke University Press, 1998), 241-242.

${ }^{88}$ Mark Malloch Brown, cited in Cameron, Democracy and Authoritarianism, 72. 
corruption, they also defenestrated every established political party. This

collapse in support for the entire political elite indicated that there was a systemic crisis of representation that went beyond the rejection of leaders as individuals.

\section{The Crisis of Representation and the Emperor Fujimori ${ }^{89}$}

The collapse of support for all the traditional parties, and the rise of Fujimori, masked a more profound crisis in Peru's politics, a crisis of representation. In order to understand this crisis, this study will utilize the theoretical work of Karl Marx and Antonio Gramsci and their respective examinations of the cases of Napoleon III and the rise of Mussolini. Marx's explanation of Louis Napoleon's base of support in the peasantry had strong similarities to Fujimori's support base in the informal sector and the campesinos. Gramsci's understanding of how Mussolini and the fascists marked an underlying crisis of hegemony for the bourgeois political parties in Italy can also be applied to the rise of Fujimori. But what the Peruvian case revealed was that the Caesarist dictatorship of Fujimori was a reaction to the implosion of the previous

89

Emperor was one of the less than kind epithets used in Peru to describe the regime of Alberto Fujimori. While unkind, this epithet accurately described Fujimori's governing style with its byzantine manoeuvring for power within the Pentagonito, the military headquarters where Fujimori resided for security reasons, along with the sudden fall from power of cabinet members and Fujimori supporters. 
economic model, an implosion that had also defenestrated all the political parties. The dictatorship of Fujimori appeared as a solution to collapse, not an impasse between dominant classes. The subsequent adoption of neoliberalism was simply one and not the only possible solution to the failure of state-led industrialization. The reasons for the adoption of neoliberalism is the subject of the rest of this thesis. But first, let us turn to an understanding of what the appeal of a caudillo, a man on horseback (or, in Fujimori's case, his famous tractors) indicated about the situation in Peru.

Beneath the bankruptcy of the political parties lay a more profound political crisis, a crisis of representation. Karl Marx in The Eighteenth Brumaire of Louis Bonaparte described the political situation of France in 1848-1852, a situation with eerie parallels to the political situation of Peru under Alberto Fujimori. Like Fujimori, Louis Napoleon rose to power through democratic elections, but, once in power, resorted to a coup d'etat to eliminate the legislature and impose a new constitutional order which was ratified by plebiscite. However, the most useful theoretical insights of Marx for this case come from his analysis of representation. As Marx argued, Louis Napoleon was able to establish his primary base of support in the peasantry because their isolation prevented the development of class consciousness:

The small holding peasants form a vast mass, the members of which live in similar conditions but without entering into manifold relations with one another. Their mode of production isolates them from one another instead of bringing them into mutual intercourse. The isolation is increased by France's bad means of communication and by the poverty of the peasants. Their field of production, the small holding, admits of no division of labour in its 
cultivation, no application of science, and therefore no diversity of development, no variety of talent, no wealth of social relationships. ${ }^{90}$

Peasants, according to Marx, were parochial, limited in vision to the local parish, unable to articulate a broader, national class vision.

In Marx's view, the very structure of peasant existence prevented them from creating their own organisations, their own representatives:

In so far as there is merely a local interconnection among these small holding peasants, and the identity of their interests begets no community, no national bond, and no political organisation among them, they do not form a class. They are consequently incapable of enforcing their class interest in their own name, whether through a parliament or a convention. They cannot represent themselves, they must be represented. Their representative must appear as their master, as an authority over them, as an unlimited governmental power that protects them against other classes and sends them rain and sunshine from above. The political influence of small-holding peasants, therefore, finds its final expression in the executive power subordinating society to itself. ${ }^{91}$

Without organisations to articulate an identity and a program, peasants could not develop organic representatives who would govern in their interests through a parliament or a congress. Instead, they turned to Louis Napoleon who, through a dictatorship, imposed order from above.

The situation of campesinos under Fujimori resembled that of the peasantry under Louis Napoleon. The campesinos of the highlands were geographically isolated in their villages. They were also isolated by their ethnicity

90

Karl Marx, "The Eighteenth Brumaire of Louis Bonaparte," Selected Writings, ed. David McLellan (New York, Oxford University Press, 1977), 317.

${ }^{91}$ Marx,"Eighteenth Brumaire," 317-318. 
and by their language Quechua. This isolation was exacerbated by Sendero who systematically destroyed roads and blockaded communication with periodic armed strikes and roadblocks. It also interrupted markets and refused to allow farmers to trade produce in an attempt to starve the cities of supplies.

However, the war in the Sierra may have actually reduced the isolation of the peasantry. In response to the threat of Sendero and the security forces, families split up and young men and fathers were sent to the cities for their survival. Yet, the migration of men to the cities did not presage the permanent destruction of family ties. Instead it was part of a generational survival strategy. Elders remained in the villages to maintain family claims to land. Middle children were fostered out to kin in the surrounding countryside, where they would be more secure. Mothers and their smallest children would then migrate back and forth from the countryside to the cities, maintaining family linkages and structures. ${ }^{92}$ The maintenance of family structures mattered because they prevented the dissolution of the refugees into the lumpenproletariat masses of the pueblos jovenes. Identities as campesinos were maintained, and many of the former refugees returned to their former homes as the threat of Sendero receded. Thus, Sendero's campaign was a double-edged sword with regards to the geographic isolation of the campesinos. On the one hand, communication was interrupted between the Sierras and the cities, while on the other hand, the war encouraged migration between the cities and the Sierra.

\footnotetext{
${ }^{92}$ Coral Cordero, 355.
} 
But Sendero's campaign against the economic infrastructure of the countryside increased rural society's economic and social homogeneity. Because Sendero specifically targeted agricultural extension stations and cooperatives, Sendero's actions destroyed the very elements in the countryside that were promoting a more complex mode of production. Without access to markets and without the resources of the cooperative structure, campesinos returned to subsistence agriculture. But a retreat to the village also implied a withdrawal from the broader society.

The war of Sendero and the economic crisis also disrupted campesino organisations and local municipal governments which, in turn, disrupted the base for political parties. In Puno, an area high in the Sierra on the Bolivian border, Sendero's strategic goal was to eliminate PUM, a communist party that had focussed on organising campesinos. It executed over one hundred activists, decapitating the local municipal leadership making political activism akin to suicide $^{93}$. It destroyed a local rural agricultural education institute, including vehicles used by PUM activists for communication..$^{94}$ The effect of this campaign was to eradicate the space used by campesinos to meet, exchange ideas, and hence articulate an organic class vision for the campesinos that could have led

93

Jose Luis Renique, "Apogee and Crisis of a Third Path: Mariáteguismo, 'People's War,' and Counterinsurgency in Puno.", in Shining and Other Paths, ed. Steve J. Stern (Durham: Duke University Press, 1998), 320.

${ }^{94}$ Renique, 319. 
to a base for a political party. ${ }^{95}$

Like the campesinos, the urban pobladores were also disarticulated and isolated within the economy. Part of the informal economy, they lacked stable employment and hence rights within the labour code. Without stable employment in large scale factories, pobladores lacked a location within which to articulate a class identity, to organise and develop their own strata of civil society organisations or political parties to impose their class vision on politics.

Interestingly, it was within this poorest strata that Fujimori found his strongest base of support. In the 1990 election in the poorest districts of Lima, Fujimori out-polled Mario Vargas Llosa by a 2:1 margin. ${ }^{96}$ Even by the elections in April 2000, Fujimori could still count on a solid base of support in the poorest sectors of society.

The key to understanding why Fujimori appealed to the pobladores lay in his symbolic appeal. Louis Napoleon was supported by the peasantry not because he actually ruled in their material self interest, but because his dynasty evoked images of peasant glory under Napoleon I: "(H)historical tradition gave rise to the belief of the French peasants in the miracle that a man named Napoleon would bring all the glory back to them." 97 Yet, instead of representing the interest of the peasantry, Napoleon guaranteed the interests of the

\footnotetext{
${ }^{95}$ Renique, 319-320.

${ }^{96}$ Dietz, 217.

${ }^{97}$ Karl Marx, "The Eighteenth Brumaire of Louis Napoleon," 318.
} 
bourgeoisie by enforcing mortgages. It was through these mortgages that the bourgeoisie extracted surplus value from the peasantry rather than rent.

Similarly, Fujimori did not govern in the interest of the poor; his appeal was based only on symbolism. In 1990, he was the chino who promised to be "a president like you," rather than another criollo. ${ }^{98}$ Fujimori's ethnic identity was associated with a respected yet neutral place in Peru's complex racial politics. He was not a pituco like Vargas Llosa, a white snob who was part of the white criollo elite. He was not a cholo, the mestizos who were both a racial and cultural mix between the indios, the "backward" indigenous peoples of the Sierra and the blanca European elites of the cities. The cholos could also be looked upon as the descendants of previous generations of migrants from the Sierra, and hence cholo status was also a cultural claim. The cholos were looked down upon by the criollos as dark skinned provincials who had recently arrived in the city with second class credentials from state universities. Yet education was the basis of cholos'status and social mobility, for education granted them access to professional jobs in education and the state.

These recent arrivistes were able to create an ideological and political space for themselves by identifying with anti-imperialism, Marxism and indigenismo. Marxism involved a critique of the class system and inequality, and thus it also involved a critique of the claims to superiority of the criollo elite. The

98

Patricia Oliart, "A President Like You: Fujimori's Popular Appeal," NACLA Report on the Americas XXX, no. 1 (July /Aug 1996), 18. 
criollos, instead of being able to claim moral superiority because of their connection to a "superior" European civilization, were revealed as compradors and thieves.

But by the 1990's, Marxism was discredited by Sendero, and statism, as an ideology, was bankrupted by failure. In Peru, ethnicity matters, and to identify with cholos meant identifying with second best. But the chinos, the Chinese a tiny minority, were outside the racial hierarchy of Peru. They were seen as hard working, honest small businessmen who were independent. Thus, in Fujimori, el pueblo could see their values of simplicity and hard work, ${ }^{99}$ like the French peasantry could see their values of courage and glory reflected in the Bonapartist myth.

But is Marx's model of the peasantry applicable to Peru when he did not address or acknowledge divisions based on ethnicity? What is useful about Marx's insight about the allegiance of the French peasantry is the emptiness of Louis Napoleon's symbolic gestures. For Louis Napoleon to wrap himself in the glories of his uncle's legacy, required no challenge to the structures of power or wealth. For Fujimori to wear the traditional hats and clothing of the hinterland also did not require that he radically alter the relationship between Lima and the Sierra. Whether the gesture was made with ermine or poncho, neither required more than the acknowledgement of the existence of the rural masses.

What Fujimori did not offer to anyone in 1990 was a concrete plan. His

${ }^{99}$ Oliart, "A President like You", 18. 
economic program consisted of an empty promise of "honesty, technology and work." But in an election about the costs of neoliberal shock policies, his vague platform allowed the electorate and political elites to project on to him their inchoate desires for a cure to hyperinflation without a shock program. Fujimori could be vague because he had no leanings, no strong opinions about economics, no program he wanted to implement when elected.

While Fujimori symbolically connected with el pueblo, for the bourgeoisie, his regime represented their abdication of power to a caudillo. Even before the 1990 campaign, Vargas Llosa had ably represented bourgeois interests in the campaign against Garcia's nationalization of banks. But once Fujimori won the election, the bourgeoisie abdicated power without seeing in Fujimori their natural representative, their voice in Peruvian politics.

Again, there are strong parallels between the Emperor Napoleon III and the Emperor Fujimori. Marx argued that during the period of 1848 to 1851, the bourgeoisie abandoned their claim to power to Louis Bonaparte in return for peace. The French bourgeoisie participated in the destruction of its own press by levying ruinous fines and terms of imprisonment on journalists who dared to challenge Bonaparte's usurpationist desires. ${ }^{100}$ The extra-parliamentary mass of the bourgeoisie vilified its own parliament, while servilely praising Bonaparte. In Marx's words, "... in order that it might then be able to pursue its private affairs with full confidence in the protection of a strong and unrestricted government. It

${ }^{100}$ Marx, "Eighteenth Brumaire," 306. 
declared unequivocally that it longed to get rid of its own political rule in order to get rid of the troubles and dangers of ruling." ${ }^{.101}$ How did the bourgeoisie respond to Bonaparte's coup d'état that dissolved their parliament and inaugurated the empire? In Marx's famous phrase: "...the bourgeois madly snorts at his parliamentary republic: 'Rather an end with terror than terror without end!'102 Unable to impose order through its own representatives and tired of political chaos, the bourgeoisie resigned its power to an elected dictator: Napoleon III. Rather the short sharp shock of a coup that dissolved civil liberties than an ongoing political crisis that interfered with business stability. The bourgeoisie preferred a dictatorship that delivered order over democracy.

The Peruvian bourgeoisie reacted in the same way as their French antecedents. On April $5^{\text {th }}, 1992$, like Bonaparte, Fujimori dissolved his legislature with an autogolpe, a self coup. The position of the bourgeois press and its organisations, mimicked that of the bourgeoisie under Bonaparte: Confiep, the organisation of Peruvian industrialists, published a communique on April $7^{\text {th }}$ supporting the coup. The editor of El Comercio, a pro business newspaper, warmly welcomed President Fujimori for a tour of their newsroom and a meeting with their editorial board at a time when military censors supervised the newsroom with machine guns. ${ }^{103}$ The following day, the editor of

\footnotetext{
${ }^{101}$ Marx,"Eighteenth Brumaire," 306.

${ }^{102}$ Marx, "Eighteenth Brumaire," 309.

103
}

Alvaro Vargas Llosa, The Madness of Things Peruvian: Democracy under Siege 
Expreso, another major pro-business newspaper, asked only that his newspaper receive the same privilege. Alvaro Vargas Llosa, the journalist son of Mario Vargas Llosa, made the telling comment: "Faust sold his soul for earthly pleasures: Peru's ruling class sold their souls on April 5 with no real guarantee of anything." ${ }^{104}$ For the promise of peace, for an end to terror, for an end to the squabbles between the Congress and the president, Peru's ruling class resigned their power to an elected dictator to use his unfettered power to redesign Peru's institutions and solve its crises.

Thus, Marx's theoretical insights into the rise of Louis Napoleon, are useful in understanding the rise of Fujimori. Underlying Fujimori's rise was the destruction of old class identities by the attack of Sendero and the economic collapse which destroyed representative links between political parties and Peruvians. In the political vacuum that followed, Fujimori was able to appeal to the electorate as an independent leader, free from the taint of the old parties in a system that beggared the many and rewarded the few without representing anyone's interests. Marx's work helps to explain why once representation had broken down in Peru, the political system became vulnerable to the rise of a dictator.

Gramsci's theory of Caesarism represents a development in the theory of a crisis in representation from Marx's Eighteenth Brumaire rather than a rebuttal.

(New Brunswick: Transaction Publishers, 1994), 87.

${ }^{104}$ Alvaro Vargas Llosa, 87. 
To Marx, a crises in representation simply reflected a breakdown in the relationship between leaders and the led. But to Gramsci, the rise of a Caesarist leader was the result of an organic crisis of the state in which no class could impose its will or its values on all others through the state. The organic crisis was then resolved by a Caesar, a leader independent of contending classes who resolved the crisis from above through coercion. Gramsci's understanding of the underlying causes of organic crises explains why Fujimori ruled as a caudillo from outside.

At the root of an organic crisis lies a crisis of authority for a hegemonic class. In a situation of hegemony, the ruling class rules more through consent than coercion. A hegemonic class obtains the consent of subordinate classes by inculcating its own values, its ideology amongst the masses.

What causes a crisis of authority is a breakdown in the ruling classes hegemony, where without the consent generated by ideology, consent was replaced by mere domination, or naked coercion. As Gramsci explained:

If the ruling class has lost its consensus, i.e. is no longer "leading but only "dominant", exercising coercive force alone, this means precisely that the great masses have become detached from their traditional ideologies, and no longer believe previously, etc. The crisis consists precisely in the fact that the old is dying and the new cannot be born. ${ }^{105}$

A crisis in authority was a crisis of moral authority, wherein the ruling class lost its legitimacy or the consent of the masses to its rule.

What underlay the loss of legitimacy was a failure by the ruling class in a

${ }^{105}$ Gramsci, 275-276. 
concrete project the nation had undertaken. As Gramsci noted:

And the content is the crisis of the ruling class's hegemony, which occurs either because the ruling class has failed in a major undertaking for which it has forcibly extracted the consent of the broad masses (war for example) or in a sudden political awakening by the subordinate classes, the satisfaction of whose demands would result in a revolution."

The major undertaking the ruling class failed at in Peru was state-led industrialization. A massive expansion in the state begun under Velasco was supposed to lead to industrialization, and increase living standards for all. But by 1990 , the project had clearly failed with rampant hyperinflation and hyperrecession.

But this brings up the difficult question: was there ever a hegemonic class, or even a dominant class in Peru's entire history? Given that Peru has a history of elected regimes that collapse into dictatorships which in turn collapse into democracies, can it be said that any Peruvian order has been stable enough to be described as "hegemonic"? First, all systems exist on a continuum of coercion and consent. Thus the mere use of force was not enough to qualify the Peruvian situation as only domination. Furthermore, as Anne Showstack Sassoon pointed out, not all hegemonies are strong, with the dominant class's ideology firmly

106

Gramsci, 210. On the surface it would seem that the situation in Peru resembled the second case. Led by the union movement, workers, through national strikes or paros, were making demands on the political system. But their demands did not inherently threaten the regime of accumulation, they demanded respect for job security and wage increases to cope with hyperinflation. The collapse of the economy marked instead the collapse of working class power as expressed through unions. 
inculcated within the mind set of subordinate classes. Most are weak alliances based on geographically dispersed class fractions. ${ }^{107}$ In cases like Peru, hegemony is shored up by trasformismo, the process of coopting insurgent classes through accommodation, corruption and elite bribery. But it is Gramsci's description of how fascism buttressed hegemony in Italy that explains the Peruvian situation. Gramsci explained that:

It (fascism) is capable of creating - and indeed does create - a period of expectation and hope, especially in certain Italian social groups such as the great mass of urban and rural petit bourgeois. It thus reinforces the hegemonic system and the forces of the military and civil coercion at the disposal of the traditional ruling classes. ${ }^{108}$

Note that support for hegemony is created by "expectation and hope", not by a concrete disbursement of power or resources.

At various times in Peru's history a development project that led to a brief boom may have swung the pendulum towards consent. Nonetheless, precisely because Peru has tended to oscillate between dictatorships and democracy, because no regime was able to perpetuate itself for long, Gramsci's theory would point to an underlying situation where there was no hegemony, no stable historic bloc but only domination. But the development project of state-led industrialization created consent by offering subordinate groups the hope and expectation of sharing in an increasing prosperity. Thus, its prescriptions for

107

Anne Showstack Sassoon, "Passive Revolution and the Politics of Reform," in Approaches to Gramsci, ed. Anne Showstack Sassoon (London: Writers and Readers Publishing Cooperative, 1982), 133.

${ }^{108}$ Gramsci, 120. 
higher wages and job security did not have to reflect the economic reality of

Peru. It merely had to offer the hope that all would be eventually incorporated in its relations of production to support hegemony. But when that hope faded, when it was clear that more of the same simply led to catastrophe, then hegemony failed.

In Peru, the collapse of the political parties was a symptom of the general collapse in the belief in state-led industrialization as an ideological project. One of the symptoms of a crisis of hegemony was a crisis in representation or the implosion of political parties. When particular leaders grow estranged from their class following, a crisis of representation creates a political vacuum for a caudillo to fill:

At a certain point in their historical lives, social classes become estranged from their traditional parties. In other words, the traditional parties in that particular organisational form, with the particular men who constitute, represent, and lead them, are no longer recognized by their class (or fraction of a class) as its expression. When such crises occur, the immediate situation becomes delicate and dangerous, because the field is open for violent solutions, for the activities of unknown forces, represented by charismatic "men of destiny". ${ }^{109}$

Without political leaders and parties that represent their classes, none of the negotiation and compromise that underlay democratic politics could effectively resolve political conflicts. Parties represented no one and hence could not deliver the consent of any particular classes to governments. Without consent, coercion or violence becomes the method to impose order. If the situation drifts further out

${ }^{109}$ Gramsci, 210 
of control, then the system becomes vulnerable to the adventure of a Caesar, a caudillo, a man of destiny.

In the case of Peru, the implosion of the parties matched Gramsci's predictions. The IU's ideology of Marxism was discredited by Sendero's violence (see above), and its class rhetoric no longer appealed to the masses. As we have seen, with the crisis, identification with class organisations like unions declined, and extreme individualism and anomie took hold. ${ }^{110}$ Membership in APRA had offered the spoils of power, but by 1990 the party was over (in both senses of the word), and the appeal of patronage jobs declined anyway as the value of civil service wages disappeared. Populism as an ideology was clearly discredited by corruption and economic collapse. The AP had lost its mass base from the 1960's of obedient peasants, as Velasco's agrarian reforms dissolved old forms of domination and IU mobilization dissolved campesino apathy. ${ }^{11}$ FREDEMO's base, the bourgeoisie, was neither numerous nor respected enough to win Vargas Llosa the election. Given the antipathy expressed towards them as pitucos, the moral authority of the bourgeoisie had clearly vanished.

Thus as all social classes were undermined by the crisis; they all became dislocated from their traditional parties.

110

Aldofo Panfichi and Cynthia Sanbourn, "Fujimori y Las Raices del Populismo," in Los Enigmas del poder: Fujimore 1990-1996, ed. Fernando Tuesta Soldevilla (Lima: Fundación Friedrich Ebert, 1996), 46.

111

Under the military government of Velasco, land reforms had finally broken the power of the landed oligarchy and the gamonal system of local tyranny. Various factions within the IU then organized the campesinos. 
But the crisis did more than simply discredit the political parties. It undermined the traditional rationale for party loyalty. The crisis turned el pueblo from a reliance on class organisations for their survival to extended kinship ties, since kin could offer a meagre form of protection from the storm of economic catastrophe with access to slight shared resources. Connections offered access to resources, jobs, information about how to obtain services, and emotional support. Patron-client ties offered some security, as the hope that a personal connection with the powerful might lead to a grant of a favour and access to the needed resources of a job, housing, health care, or building supplies. ${ }^{112}$ The focus of collective organisation shifted from class to the more purely social forms of identity found in sports teams, religious organisations, migrant organisations, and organisations based on provincial identities. ${ }^{113}$ These new forms of identity offered contact with members of other social strata who could offer resources.

According to Gramsci, when the ruling class is faced with a crisis of authority, it will attempt first to reconstitute its political rule with a new political party. This new party will represent a fusion of all former parties that had represented the ruling class, "a single party that better represents and resumes the needs of entire class," 114 a party that then would attempt to crush opposition and reimpose hegemony. In the case of Peru, Vargas Llosa and his FREDEMO

\footnotetext{
${ }^{112}$ Panfichi and Sanbourn, 47.

${ }^{113}$ Panfichi and Sanbourn, 46.

${ }^{114}$ Gramsci, 211.
} 
alliance represented a fusion of old political cadres of the AP and PPC and the new Libertad formation, which was formed to protect the bourgeoisie and capitalism. Their project was to dissolve the old state capitalist structures with a healthy dose of neoliberalism. Yet while Vargas Llosa clearly represented the interests of the elites (too clearly for the subordinate classes to vote for these pitucos), he failed to receive the mandate he required to impose his reforms democratically. The failure to achieve his desired mandate also signified the failure of hegemony of the ruling class because the rejection of Vargas Llosa was a rejection of the political project of the ruling class.

The failure to re-establish hegemony reflected a strategic impasse. According to Gramsci, "static equilibrium exists (whose factors may be disparate, but in which the decisive one is the immaturity of the progressive forces); it means that no group, neither the conservatives nor the progressives has the strength for victory and that even the conservative group needs a master."115 By progressive, Gramsci meant forces that would revolutionize the relations of production, while conservative forces referred to those who use dictatorship to protect their position from change.

Was there a balance of forces in Peru in $1990 ?$ There was certainly an impasse, a situation where neoliberals were unable to achieve a clear mandate to impose structural reforms. In the second round run off of the 1990 election, Fujimori appealed to the "conservative" forces, by promising not to impose

\footnotetext{
${ }^{115}$ Gramsci, 211.
} 
feared shock policies. Note that the "conservative" forces in Gramsci's theory are those who would resist changes in the order, and hence would be the factions of the IU, IS, and APRA who were against privatization, trade liberalization, cutbacks in government spending. However, Fujimori himself and Cambio 90 were not a part of this left-right, progressive versus conservative split. Indeed Fujimori's appeal to the electorate was based on avoiding the entire question. Instead of concrete policy proposals, Fujimori offered the nebulous slogan of "honesty, technology and work", and in fact had no written plan of government when elected. ${ }^{116}$ The situation in Peru, then, was less of a polarized deadlock, than a chaotic situation where no class fraction could generate majority support to deal with the crisis. The Peruvian political system was paralysed not because it was polarized, but because the system of representation had broken down for all classes. Because all parties were discredited and despised, Peruvians were willing to turn to an outsider, in large part because he was an independent.

However, despite the fact that implosion rather than polarization describes the situation in Peru, Gramsci's description of a Caesarist situation still holds true. When the rapid fusion of all conservative forces into a single party fails to solve "an overriding problem of its existence and of fending off mortal danger,",117 then the dominant classes turn to a master, a Caesar who resolves the crisis of authority by imposing order through dictatorship.

\footnotetext{
${ }^{116}$ Maxwell A. Cameron, "The Eighteenth Brumaire of Alberto Fujimori," 48. ${ }^{117}$ Gramsci, 211.
} 
What Marx and Gramsci's theoretical insights reveal are the structural roots of Fujimori's authoritarianism. Fujimori's dictatorial tendencies appear as less the result of his own egotistical drive to power, than as the structural answer to a profound political crisis of hegemony. Instead of the autogolpe springing from Fujimori's personal lust for absolute power, it appears instead to be caused by a need to reconfigure the structure of the Peruvian state, the economy and society. The collapse in support for every major political party can be understood as a crisis in representation caused by a crisis in hegemony caused in turn by a crisis of faith in the economic model of state-led industrialization, a crisis that shattered loyalty to every party and institution in Peru. Because everything had failed, power had to be concentrated into the hands of the executive so that everything could be transformed in a new order.

But the situation where hegemony collapsed, only to be resolved by a Caesarist dictator, was not new in Peru. Indeed, Alvaro Vargas Llosa attributed Fujimori's drive to reshape Peru's institutions to what he described as an Adam complex. Throughout Peru's history, its leaders wanted to become like Adam, the first man. They desired to be the man of destiny who would create Peru's first authentic democracy. Fujimori was simply one of a long line of leaders from Legúia, to Sánchez Cerro, to Odría, to Velasco, who reshaped Peru's institutions as though nothing had existed before them. ${ }^{118}$ But while some of Fujimori's actions may be attributed to personal impatience and vainglory, this

\footnotetext{
${ }^{118}$ Alvaro Vargas Llosa, 51.
} 
does not explain Fujimori's continued popularity after the autogolpe. A poll conducted by IPEA, a respected neutral pollster, revealed that $71 \%$ of the population supported Fujimori's coup ${ }^{119}$. In 1995, that support continued when Fujimori won an overwhelming second mandate. The people supported their caudillo, and rejected their political representatives and abandoned their parties. Thus the phenomenon of Fujimori goes beyond personality, to structural roots in Peruvian society.

The advantage of using Marx and Gramsci to analyse this situation is that it links the collapse of the old order to the defenestration of the parties and the defenestration of leaders from civil society. The previous political elites lost support not only because they were incompetent, but also because they were irrelevant. They articulated the dreams, values and aspirations only of the old order.

\section{Conclusion:}

The social crisis that stemmed from the economic crisis generated a crisis of anomie, rather than a crisis of insurgent classes struggling for power. The political crisis did not stem from a struggle between workers and the bourgeoisie, rather it stemmed from a collapse in class identities caused by the economic collapse. The economic collapse and security crisis destroyed the bonds of

Mirko Lauer, Diás Divididos: Columnas politícas de los Años 90 (Lima: Adec Atc, 1994), 54. 
loyalty between voters and the parties to the point that no party represented anyone. The twin crises in security and in the economy created a third crisis, a crisis of representation where the political elite lost their ability to represent their followers. Without parties that could represent them, Peruvians turned to an outsider who would solve the crises: Alberto Fujimori.

Faced with the collapse of the old order, Fujimori turned democracy into autocracy. But the centralization of all power into the president's hands gave Fujimori the capability to resolve the hegemonic crisis by transforming the state and social relations of production. The transformed state then enforced the transition from state-led industrialization to neoliberal relations of production based on flexibility and insecurity. Thus Caesarist dictatorship was a response to the implosion of the old order.

But if the causes of Peru's turn to authoritarianism lay in the triple crises of Sendero, economic collapse, and a crisis of representation, what role then does neoliberalism play in explaining the rise of authoritarianism? Sendero and the economic crisis destroyed the linkages between political representatives and the represented, and created a political vacuum that led to the rise of Fujimori. The role that neoliberalism played was to provide Fujimori's regime with its ideological premisses and goals while at the same time providing him with a policy direction. The necessity of implementing profound policy changes legitimated the use of authoritarian measures to rescue Peru from its crises. Neoliberalism, then, appeared not as a cause of authoritarianism, but rather as the ideological glue that legitimated and held together an authoritarian project. 
Thus when Fujimori was faced with a society that had collapsed and imploded he turned to neoliberalism as the ideology that would allow him to redefine Peru. The kind of order described by neoliberalism and hence the new basis for relations between Peruvians and their state is the subject of the next chapter. 


\section{Chapter Two: The Political Consequences of Neoliberal Ideology}

To resolve Peru's crisis, Fujimori needed an ideology that would provide a blueprint on how to reorganise society, the state and the economy and justify his usurpation of all power as the Caesarist saviour of Peru. To offer a way out of the failure of the previous order any ideology had to offer a different vision for society and its relationship to the state, a different governing purpose for that state, and a rationale that legitimated different social relations of production. But the new ideology had not merely to offer a new vision for society, it also had to undermine and overturn the previous order's ideals in order to erase any lingering loyalties to the institutions and relationships that had been created within the old system. In other words, neoliberalism had not only to offer a different vision of the future, but it also had to erase the moral ground from which the previous order had legitimated itself.

The irony of this situation was that Fujimori was not originally a believer in neoliberalism. That distinction belonged to his opponent Mario Vargas Llosa. While Fujimori's conversion was driven by international pressure (see Chapter Four), neoliberalism as an ideology offered him a justification for unravelling the failed arrangements of the previous order.

Within the broader structure of this thesis, this chapter provides an examination of how shifts within the realm of ideas and ideals could support a transformation of an order. If the underlying argument of this thesis is true, that structural affinities between ideologies, the state and relations of production will mutually reinforce each other, then neoliberalism provided moral and ethical 
grounds that justified a new vision of the state and a new ethos for relations of production.

But beyond offering a different moral vision that legitimated a new order, neoliberalism also undermined the moral case for the previous order. What is interesting to note is that neoliberal theorists used the technique of inversion to discredit previous practises, changing good to bad, bad to good. These arguments then provided the moral grounds on which to impeach previous arrangements beyond the grounds of their economic failure.

The purpose of this chapter is to uncover the premises of neoliberalism in order to ascertain its vision for its new order. An examination of the principles of neoliberalism reveals the rationale behind its distaste for the state and any interference with the market. But just as importantly, it exposes the silences of neoliberalism and how its assumptions allowed neoliberal theorists to repress questions about class and equity, about the duties of the state and about what constitutes democracy.

However the purpose of this chapter is not to dispute or debate the validity of the arguments put forward by neoliberal theorists. Indeed many of the hidden premises revealed by this study are rather ludicrous. Instead of refuting these premises and arguments point by point, this study opts to let these ideas stand or fall by themselves without commentary or rebuttal. This is a study of the political and social consequences of implementing this school of thought not a critique of its content. By exposing what neoliberalism's core beliefs and arguments are, we can then understand what kind of order it could and would 
legitimate. However let there be no misunderstanding that exposing neoliberalism's arguments does not signal agreement.

On a purely methodological note, this chapter will analyse the works of Friedrich von Hayek and Milton Friedman. Hayek was the foremost proponent of the Austrian school of neoliberalism. His work provided the philosophic underpinnings and justifications for neoliberalism. ${ }^{1}$ Milton Friedman was the most prominent of the Chicago school, whose theoretical work was on monetarism, but who also played a prominent role in popularizing neoliberalism through his writings and a column in the American popular newsmagazine, Newsweek.

Within the broader structure of the thesis, the previous chapter examined the context for the rise of Fujimori as a Caesarist dictator who would impose a neworder based on the prescriptions of neoliberalism. This chapter examines what the vision of neoliberal theorists was for the state and relations of production, to understand how following this ideology justified the dismantling of labour rights and protection by the state.

This chapter will reveal the underlying moral and ethical arguments that neoliberal thinkers made to justify a new order. These arguments provided a moral justification for the dismantling of the state's duty to provide services for

Hayek's importance to the neoliberal revolution in British politics was evident in this statement by Margaret Thatcher to the House of Commons in 1981: "I am a great admirer of Professor Hayek. Some of his books are absolutely supreme The Constitution of Liberty and the three volumes of Law, Legislation and Liberty-and would be well read by almost every honourable member." Quoted in Jim Tomlinson, Hayek and the Market (London: Pluto Press, 1990), X-XI. 
citizens not only because the state was incompetent, but also because it was immoral to do so. They also legitimated the dismantling of the power of unions to defend their members. In combination, the destruction of union power and the elimination of the state as a site for struggle left subaltern classes at the mercy of market forces. This all began with an extreme form of individualism that left no room for solidarity and the common good.

\section{The Neoliberal Ontology: Extreme Individualism and the Elimination of the Common Good}

Underlying the neoliberal rejection of the common good was a liberal ontology, an ontology that had profound political consequences when applied to societies like Peru. At the core of neoliberalism lies the classic liberal notion that all that exists is the individual, and all that matters are his or her sovereign desires. For neoliberals like Hayek, questions of values are only a matter of individual preferences:

...since, strictly speaking, scales of values can exist only in individual minds, nothing but partial scales of values exist - scales which are inevitably different and often inconsistent with each other. From this, the individualist concludes that the individuals should be allowed, within defined limits, to follow their own values and preferences rather than somebody else's; that within these spheres the individual's system of ends should be supreme and not subject to any dictation by others. It is the recognition of the individual as the ultimate judge of his ends, the belief that as far as possible his own views ought to govern his actions, that forms the essence of the individualist position ${ }^{2}$.

2

Friedrich von Hayek, The Road to Serfdom (Chicago: The University of Chicago Press, 1944), 59. 
In sum, because individual preference is the only source of values, there is no source of values beyond transitory individual tastes.

Without a site of meaning beyond the individual, the common good simply becomes the sum of all individual desires. Thus, Hayek stated ... "what is called social ends are for it merely identical ends of many individuals - or ends to the achievement of which individuals are willing to contribute in return for the assistance they receive in the satisfaction of their own desires."3 Within Hayek's philosophy, there is no society beyond the individual, no community greater than the sum of its parts. Common goals do not exist for they are only the camouflaged desires of a group of individuals who pursue a common project only as long as the expenditure of individual effort is matched by individual reward.

The result of this extreme individualism was a rejection of the possibility of discovering the common good as a collective project. Without a sense of collectivity, concerns for the well being of fellow citizens could be dismissed and selfishness as the only moral code becomes the standard for ethical conduct. This, in turn, legitimated an economic system that delivered extreme inequality. Hayek's extreme individualism has consequences for democracy. In his view, sovereignty lies with each individual, a sovereignty that could not be abridged by reference to the will of the majority. Each individual's desires are sovereign, capable only of being amalgamated, not overruled, for the greater good, nor changed or constructed by interaction with others in society. Indeed,

\footnotetext{
${ }^{3}$ Hayek, The Road to Serfdom, 59-60.
} 
desires, in Hayek's construction of individualism, are pre-social and innate. Majority opinion has no authority over an individual's rights and desires. Therefore the business of democracy with its attempts to achieve consent and majority support for collective action is moot, since one individual can veto the action of the majority if it infringes on his/her desire. The will of the majority is tyranny, not only if it infringes on the rights of the minority but also if it infringes on the individual at all. Thus, the consensus and coalition building of democracy becomes irrelevant.

To neoliberals, the ultimate goal is to minimize social and political interference in order to maximize individual freedom. Society appears not as the site of freedom where we discover meaning and purpose, but as a barrier, infringement and threat to individual liberty. Thus, Milton Friedman stated that "[a]s liberals, we take the freedom of the individual, or perhaps the family as our ultimate goal in judging social arrangements." Social arrangements are to be judged solely on their ability to deliver the maximum liberty to every individual.

Yet social arrangements are not judged on the basis of a utilitarian calculus of the greatest liberty for the greatest number. This might justify limiting liberty for the few to maximize liberty for the many which would, for example, justify measures to protect the rights of labour against capital. Entrepreneurs might be forced to pay a living wage in order to protect the liberty of workers or

Milton Friedman, Capitalism and Freedom (Chicago: The University of Chicago Press, 1969), 12. Since the family is a social construct, Friedman contradicts his own argument here that only the individual exists. 
their freedom from want or fear of hunger. Instead, the calculation is based on universal rights, wherein the infringement of one person's liberty infringes upon all. As long as an action infringes on one person's liberty, any action by the state could be dismissed as illegitimate. Thus absolute liberty as a universal right helped to support the neoliberal assault on the state by providing grounds upon which the neoliberals could anathematize all state action in principle.

\section{The Neoliberal Fear of the State}

At the heart of the neoliberal construction of liberty lies a deep and abiding distrust of government, especially government interference in the economy. Underlying this distaste lies the argument that all planning and government interference in the economy automatically leads to a slippery slope to totalitarianism. Hayek argued that because of the sovereignty of individual tastes, there can be no agreement on ends or a hierarchy of values. Without agreement on ends, there can be no democratic agreement on the goals of a central plan for the economy. ${ }^{5}$ According to Hayek:

Majorities will be found where it is a choice between limited alternatives; but it is a superstition to believe that there must be a majority view on everything. There is no reason to believe that there should be a majority in favour of any one of the different possible courses of positive action if their number is legion. Every member of the legislative assembly might prefer some particular plan for the direction of economic activity to no plan, yet no plan may be preferable to a majority to any plan at all.

\footnotetext{
${ }^{5}$ Hayek, The Road to Serfdom, 61.
} 
Nor can a coherent plan be achieved by breaking it up into parts and voting on particular issues. A democratic assembly voting and amending a comprehensive economic plan clause by clause, as it debates an ordinary bill, makes nonsense. An economic plan, to deserve the name, must have a unitary conception. ${ }^{6}$

Here Hayek is simply asserting that it is not possible to come up with a democratic majority in favour of one central plan for the economy. A central plan requires a unitary conception, according to Hayek, which is impossible in a democracy given that democratic decision making is based on haggling and bartering between individual interests. Because it is impossible to reconcile every individual's sovereign desires with one central plan, a democratic central plan for the economy is also impossible.

Hayek's argument depends upon this assertion to prohibit any possibility that state planning or collective ownership could be used to serve democratic purposes. He argues that in a democracy it is impossible to achieve majority support for the goals of central planning because of the infinite and disparate desires of sovereign individuals. Hayek can then argue that totalitarian dictatorship is the inevitable result of government interference in the economy: "Yet agreement that planning is necessary, together with the inability of democratic assemblies to produce a plan, will evoke stronger and stronger demands that the government or some individual should be given powers to act

\footnotetext{
${ }^{6}$ Hayek, The Road to Serfdom, 64.
} 
on their own responsibility. ${ }^{.7}$ But here Hayek conflates economic planning by the state with any interference in the market, arguing that interference or regulation would lead inevitably to planning, and any planning to totalitarianism. Having labelled democracy as incapable of producing coherent direction to the economy, Hayek can then argue that any planning leads inexorably and inevitably to totalitarian rule.

Hayek extended this prohibition against state direction in the economy to include even his own field of study: economics. In his Nobel prize address Hayek included economists in his indictment of all social scientists for what he described as the "pretense of knowledge." Ironically, it was these economists as technocrats that Hayek relied on to impose his vision of a state that would never interfere with the sovereignty of the markets. Technocrats would gain their knowledge about the importance of economic liberty through understanding Hayek. Technocrats then would form a disciplined elite who would resist demands from the populace for action and hence keep the market pure.

This slippery slope argument then allows neoliberals to set up a false dichotomy between the state and the market. Since any form of state involvement in the economy leads to slavery by the state, then its opposite, the free market, must be the site of liberty and good.

\footnotetext{
${ }^{7}$ Hayek, The Road to Serfdom, 67. 8

Miguel A. Centeno, "The Politics of Knowledge: Hayek and Technocracy," in The Politics of Expertise in Latin America, ed. Miguel A. Centeno and Patricio Silva (New York: St. Martin's Press, 1998), 41.
} 
Milton Friedman, the American economist, used this antimony to set up a

bleak Manichean choice between totalitarianism and the free market.

Fundamentally, there are only two ways of coordinating the economic activities of millions. One is central direction involving the use of coercion - the technique of the army and of the modern totalitarian state. The other is the voluntary cooperation of individuals -the technique of the marketplace. ${ }^{9}$

With a dichotomy established between the free market and the tyrannical state, the ground is established to lead an attack on the state as the source of all evil.

However, there is more to neoliberal support for the market than simply a negative view of the state. To neoliberals, the market is also the site of liberty, the location of freedom, where everyone can participate without restriction in the satisfaction of their own tastes. Friedman begins his celebration of the market by demonizing the state as a threat to freedom because of its potential to coerce its citizens. The market disperses power, and is therefore good because it protects us from the state. The following excerpt from Milton Friedman's Capitalism and

Freedom, contains the kernel of this argument:

Political Freedom means the absence of coercion of man by his fellow men. The fundamental threat to freedom is power to coerce, be it in the hands of a monarch, a dictator, an oligarchy, or a momentary majority. The preservation of freedom requires the elimination of such concentration of power to the fullest possible extent and the dispersal and distribution of whatever power cannot be eliminated - a system of checks and balances. By removing the organisation of economic activity from the control of political authority, the market eliminates this source of coercive power. It enables economic strength to be a check to political power rather

\footnotetext{
${ }^{9}$ Friedman, Capitalism and Freedom, 13.
} 
than a reinforcement. ${ }^{10}$

Thus, the free market is proposed as the cure for the threat to liberty embodied in the state. Friedman goes on to state that because there are lots of millionaires, economic power is more dispersed than political power. In a socialist society, who would pay for a dissident acolyte for capitalism? But as Friedman states, "In a capitalist society, it is only necessary to convince a few wealthy people to get the funds to launch any idea, however strange, and there are many such persons, many independent foci of support."11 This statement assumes that there is no class bias for the bourgeoisie, no perspective formed by their wealth that would lead them to support overwhelmingly those who reflected their own economic interests. ${ }^{12}$

While power in politics is denounced as coercion, economic power is treated as though it did not exist. Economic coercion is made to vanish by a narrow definition of coercion. Coercion matters because freedom is defined as the absence of coercion. ${ }^{13}$ According to Hayek, "coercion implies both the threat

${ }^{10}$ Friedman, Capitalism and Freedom, 15.

${ }^{11}$ Friedman, Capitalism and Freedom, 17. 12

How Friedman could assume away the existence of class bias is mystifying. However, once Friedman ignores class, he can construct an argument that the market is the site of freedom. Thus he disposes of arguments about inequality being caused by the structures of power in the market by ignoring the very existence of class.

13

Friedrich von Hayek, The Constitution of Liberty (Chicago: Henry Regnery Company, 1960), 131. 
of inflicting harm and the intention thereby to bring about certain conduct."14 By this definition, all actions in a workplace by an employer would be coercive, since it is the threat of harm by either firing or sanctions, that enables the employer to maintain discipline. But there is no coercion in the free market, according to neoliberal thought, because the existence of a great many potential employers means that no one is forced to hire themselves out to anyone in particular. Because workers can choose between offers, the choice to take a particular job is always voluntary. ${ }^{15}$ According to neoliberals, as long as there is choice between employers, everyone retains their liberty.

The obvious rebuttal of this position is that hunger and desperation deprive humans of their ability to reject terms when the choice lies between wage slavery and death. Without real choice there is no free consent, and hence no liberty. Yet Hayek argued that even this does not constitute coercion. "Even if the threat of starvation to me and perhaps my family impels me to accept a distasteful job at a very low wage, even if I am "at the mercy" of the only man willing to employ me, I am not coerced by him or anyone else."16 As long as choice remains, no matter how painful, liberty remains, according to Hayek. The hallmark of freedom, then, is the choice between employers provided by the free market system of capitalism. If there is any element of consent, no matter under

\footnotetext{
${ }^{14}$ Hayek, The Constitution of Liberty, 134.

${ }^{15}$ Hayek, The Constitution of Liberty, 121.

${ }^{16}$ Hayek, The Constitution of Liberty, 137.
} 
how much pressure or how unpalatable the choices, then coercion does not exist and freedom is unaffected.

This narrow construction of coercion allows Hayek to dismiss the problem of the imbalance of power between master and servant, entrepreneur and worker, employer and employee. With Hayek's narrow construction of coercion, this imbalance ceases to be a problem, and workers can be said to consent freely to the terms of employment, as long as they can quit. Under this limited definition, the market becomes the location for the realization of liberty since it is the location of choice between jobs. Government action to create a more level playing field in the labour market and regulate employment becomes an infringement on the liberty of employers and employees to negotiate with each other as individuals. Government threatens all freedom when it regulates the labour market in the name of fairness.

According to Hayek, since the market is regulated by competition, relative prices allocate resources efficiently and co-ordinate economic activities without coercion.

And it [economic liberalism] regards competition as superior not only because it is in most circumstances the most efficient method known but even more because it is the only method by which our activities can be adjusted to each other without coercive or arbitrary intervention of authority. Indeed, one of the main arguments in favour of competition is that it dispenses with the need for "conscious social control" and that it gives the individuals a chance to decide whether the prospects of a particular occupation are sufficient to compensate for the disadvantages and 
risks connected with it. ${ }^{17}$

Free markets are preferred because they are "without coercion or arbitrary intervention of authority" and hence voluntary.

Because market outcomes are accidental, they are, by definition, beyond justice. According to Hayek, the market distributes goods and rewards beyond any single person's will, choice, plan, or intent. Standards of justice can only be applied to individual conduct, and since no individual orders the market, no one can be held accountable for market outcomes. The market is thus above and beyond our right to judge: "In a free society in which the position of different individuals and groups is not the result of anybody's design-the differences in reward simply cannot meaningfully be described as just or unjust." ${ }^{.18}$ Inequality is neither good nor evil; it just is. Thus, Hayek dispenses with the possibility of "social justice."

Yet because market outcomes are beyond the standards of justice, because they are the outcome of natural processes, they have paradoxically become, the arbiter of justice. Whatever the results, people must simply accept market outcomes as natural and inevitable - as the necessary price they pay for the market which is the only source of freedom. Justice must therefore subordinate itself to the results of the market and whatever the market produces

\footnotetext{
${ }^{17}$ Hayek, The Road to Serfdom, 36.

18

Friedrich von Hayek, Law, Legislation and Liberty Volume 2: The Mirage of Social Justice (Chicago: University of Chicago Press, 1976), 70.
} 
becomes justice. ${ }^{19}$ If market forces produce wealth only for the few, then their wealth is inherently fair. But if political action produces redistribution, then the outcome is unfair because it was not the natural outcome of market forces.

In addition the market provides a moral standard from which Hayek and Friedman can assail their opponents as immoral. Because of their ontological and epistemological claims, there are no exogenous source of morality by which to judge the market. The logical argument for doing this is that if the market is the source of order, liberty, and justice, then the market becomes the ultimate object to be valued. Because the market is good, then neoliberals can (and do) assail their opponents on moral grounds for threatening the market and all it provides. Thus Friedman assails the imposition of wage and price controls as "deeply and inherently immoral" because they dare to substitute the rule of men for the rule of law and voluntary cooperation. ${ }^{20}$

From an original metaphysical position that proclaimed the impossibility of arriving at universal values, neoliberals have promoted the market into being the penultimate value. Instead of either the hand of God or the democratic will of the people, sovereign authority must be ceded to the invisible hand of the market. Those who dare dissent are dismissed not for their sins against God or their fellow men, but for their sin against market forces that are the embodiments of

Conrad Waligorski, The Political Theory of Conservative Economists (Lawrence: University of Kansas Press, 1990), 137.

${ }^{20}$ Waligorski, 140. 
freedom, justice and morality.

\section{To Restrict the State}

For neoliberals the danger to liberty represented by the state justified a massive retrenchment in its scope. First, because any state action was inherently dangerous as a threat to all liberty, the state became the threat to freedom. This generalized fear inverted the citizens' traditional feelings toward the state. Instead of the state being the site where citizens could together decide the shape of their society and their common future, the state instead became a permanent and ever present threat of tyranny and oppression. Second, the compulsive nature of the road to serfdom meant that the intent of both political leaders and the public was irrelevant. Since all planning led to tyranny, good intentions to address social problems led automatically to a bad result. Third, there was no possibility of choice or deliberation in politics. If all planning led to serfdom, then there was no possibility that political leaders and the public could limit, through public discussion and deliberation, the extent of planning or policy at the point which public action infringes on private choice. Fourth, fear and loathing of state action in general, legitimated an attack on all programs in particular. Programs like universal health care that may, at first, seem to have beneficial results could be dismissed as the first scary step on the road to serfdom. Government interventions to redress inequality were inherently "unjust, 
oppressive and destructive" because they interfered with market justice. ${ }^{21}$

Progressive taxation was oppressive because it involved robbing the rich of the just desserts of their labour and capital; it oppressed the minority(the rich) for the benefit of the majority. ${ }^{22}$ Thus the compulsion of the road to serfdom generated a generalized fear and distrust of government that corroded the rationale for citizens' participation in politics, and provided the justification for a general attack on specific government programs designed to promote equality.

According to the neoliberals, because no structural failures can exist, policies designed to ameliorate inequity were simply the result of special interest groups successfully using their political power to corrupt the market. To protect one group against the market is to deny others the same chances, the same system from which they derived their position:

The satisfaction of such claims by particular groups would thus not be just but eminently unjust, because it would involve the denial to some of the chances to which those who make this claim owe their position. For this reason it has always been conceded only to some powerfully organised groups who were in the position to enforce their demands. Much of what is today done in the name of 'social justice' is thus not only unjust but highly unsocial in the true sense of the word: it amounts simply to the protection of entrenched interests. ${ }^{23}$

\footnotetext{
${ }^{21}$ Waligorski, 14.

22

See Friedrich von Hayek, The Constitution of Liberty, Chapter 20. Hayek approvingly quotes John Stuart Mill's statement that progressive taxation is "a mild form of robbery," 308 .

23

Hayek, Law, Legislation and Liberty, Volume 2: The Mirage of Social Justice
} 
Thus all groups seeking social justice or redistribution are illegitimate, and the homeless and the hungry are only seeking to preserve their privileges.

There was also an ontological basis for the neoliberals' dismissal of the legitimacy of groups in society. Since we are only individuals, identity based on membership in a group has no content beyond a short term alliance to extract value from everyone else. Indeed, to neoliberals, any group claim can be dismissed as an attempt by the few to blackmail the many.

The claim that all groups constitute only special interests seeking privilege has enormous political consequences. This claim, along with the fear of government intervention, underlies the neoliberal assault on government. The result of this assault on government has been a massive reduction in the legitimate scope of state activities, wherein problems that used to be regarded as legitimate state duties are to be left to market forces - either to resolve or simply to be abandoned as problems that are beyond the state's capabilities. The result is a series of prohibitions against state regulation of the market or attempts to facilitate class compromise and attain social peace.

According to this vision, the state must abandon all of the increases in responsibilities and functions which evolved in the twentieth century and retreat to the nineteenth century model of a laissez-faire state. The state was to be absolved of responsibility and prohibited from intervening in five broad areas of social concern: organizing economic development, responding to market

(Chicago: University of Chicago Press, 1976), 95-96. 
failures, promoting redistribution, reducing class conflicts and securing legitimation.

The responsibility for general economic development is one of the most crucial responsibilities that the state must abandon. Previously, the state had both the capability and the responsibility for planning for, and for producing economic development. States were to invest in strategic sectors of the economy from transportation and energy to the production of steel and capital goods. But according to neoliberalism, all these planning activities simply led to totalitarianism. Thus, under neoliberal structural adjustment policies, the state's role in the economy was reduced and all state enterprises were to be privatized.

As the economic role of the state was diminished, state responsibility was also reduced. If planning was to be abandoned, then the state was no longer politically responsible for development. Instead the market, if left alone, will solve all problems and, in the long run, spontaneously lead to development. Indeed, the neoliberal technocrats who set economic policy for Fujimori refused to have a plan for development, since this would run counter to their neoliberal belief that the economy should be guided by the market. ${ }^{24}$ So the government made no provision to even set priorities for targeted state investment to facilitate development. Thus the perception of the state changed from being the generator of development, to only being a barrier.

24

Carol Wise, "State Policy and Social Conflict," in The Peruvian Labyrinth, ed. Maxwell A. Cameron and Philip Mauceri (University Park, Pennsylvania: Pennsylvania State University Press, 1997), ff 22, 92. 
Broad areas of government policy and activity designed to correct market failures were prohibited in defence of the sovereignty of the markets. Housing for the poor is a classic example of market failure. The proposal that free markets will provide housing is absurd when applied to Peru. By 1990 in Lima two thirds of the population lived in pueblo jovenes, the jerry-built extralegal squatter settlements constructed as a response to the failure of the market to provide enough housing. ${ }^{25}$ In Peru, the problem was not enough government intervention in the provision of its infrastructure, not too much.

A third major area where government action is prohibited is any action that would address inequality. According to Milton Friedman, inequality is justified because, upon entering the market, we all agree to the terms of the lottery. Inherited wealth is no different from wealth due to merit, since it is the result of decisions made by one's parents, or luck, which no one can object to since it is arbitrary. ${ }^{26}$ For Hayek, any action that is designed to address inequality must be arbitrary, since it would have to be tailored to every case and would also be inherently unequal. Because it would entail unequal treatment, redistributive measures would lead to the end of equality and hence end the rule of law. ${ }^{27}$ Thus, Hayek argued:

25

Robin Kirk, The Monkey's Paw. New Chronicles from Peru (Amherst: University of Massachusetts Press, 1997), 116.

26

Friedman, Capitalism and Freedom, 161-162. The metaphor of the lottery is Friedman's own.

${ }^{27}$ Hayek, The Road to Serfdom, 74-79. 
formal equality before the law is in conflict, and in fact incompatible with any activity of the government deliberately aiming at material or substantive equality of different people, and at any policy aiming directly at a substantive ideal of distributive justice must lead to the destruction of the Rule of Law. ${ }^{28}$

Thus any policy designed to reduce inequality is inherently unjust and threatens the end of the rule of law.

From a general prohibition against governments redistributing wealth, there is a set of specific policies that are to be prohibited. Thus, neoliberal theorists argued against progressive taxes and for a flat tax rate, because to transfer income effectively from one group to another smacks of coercion while it infringed on individual liberty. ${ }^{29}$

Overall, the neoliberal assault on the state entails a massive depoliticization of class conflict. By dismantling the state's ability to intervene in class relations and the economy, these theorists were, in effect, seeking to remove all issues of distribution from politics. By privatizing the provision of social services, neoliberals effectively removed from the political sphere the possibility of common action through the state improving the lives of citizens. Instead of political action being a means for citizens to achieve their hopes and dreams, all hopes and dreams are to be pursued solely in the private, and individual realm of the marketplace. Thus, by rendering the state incapable of action, neoliberal writers effectively prevented subordinate classes from using

\footnotetext{
${ }^{28}$ Hayek, The Road to Serfdom, 79.

${ }^{29}$ Friedman, Capitalism and Freedom, 174.
} 
their political power.

But beyond changing the role of the state, neoliberal economists also sought to eradicate union power and hence increase the power of capital all in the name of securing justice as the free market.

\section{The Assault on the Rights of Labour}

The neoliberal assault on subaltern classes involved not only the dissolution of the welfare state, but also an assault on the labour movement. While all labour rights had not been extended to every Peruvian, the fortunate few in formal sector had achieved rights to pensions, medical services and job security. For those who worked in the formal economy, their privileges and benefits were protected by a generous labour code. Dismantling this system involved dissolving the previous mode of regulation and its replacement by a more ruthless neoliberal mode.

On the surface, it might seem that the assault on the rights and capabilities of labour unions was not part of the overall mission to reduce the scope of the state. Historically, unions were encouraged by reform liberals as a corrective to an imbalance of power between workers and capital. However, the granting of labour rights was not merely the gift of beneficent reform liberal leaders. Labour rights were won by the struggles of workers in a series of epic strikes. While the granting of union rights was the result of a process of elite accommodation and co-optation of working class mobilization, they were legitimized within the broader package of increased social rights that composed 
the welfare state.

In the case of Peru, labour rights were extended from the top down, usually by dictators seeking a populist base. ${ }^{30}$ But the extension of rights was still in response to a mass mobilization that threatened the stability of the government. Thus labour rights, however they were granted, were always the result of a political struggle where the state codified new rights.

The neoliberal approach to class conflict was unique, for it proposed that the state should be removed from the resolution of class conflicts. Traditional state methods to control the labour movement in Latin America were those of outright repression, corrupting union leaders or institutionalizing class compromise through mediation. The state had always played a central role in conflicts between capital and labour in Latin America.

Neoliberal theorists wanted to prohibit state intervention in labour disputes thus removing the state from its historic role in facilitating class compromise by abandoning the entire subject of labour relations. According to neoliberal economists, increased wages produced by government interference in labour markets had simply sparked inflationary pressures. State intervention to protect labour had created labour market rigidities which prevented the natural reallocation of labour power to more productive sectors of the economy.

30

In the case of Peru, union rights were granted as the outcome of political struggles, usually by populist dictators seeking to create a mass base of support (see David Collier and Ruth Collier, Shaping the Political Arena (Princeton: Princeton University Press, 1991). For a more thorough examination of the Peruvian case see Chapter 6 of this thesis. 
In order to compete globally and increase productivity, the state must not interfere in the labour market. According to this perspective, once the state's role was eliminated from labour relations, labour conflict would cease to be a political issue. Neither capital nor labour would then be able to appeal for state intervention through political pressure, and social conflict would become depoliticized. Because the market spontaneously created order, class conflict would disappear as all accepted the just distribution of the market.

This vision of the state's role in labour relations inverted its function. Instead of acting as the useful mediator and adjudicator that could resolve social conflict by defusing labour strife, the state's intervention in labour relations was portrayed as preventing social peace by preventing the market from fulfilling its natural function. Neoliberal theorists sought to silence class conflicts by silencing the issue as a subject of political responsibility and then expecting class conflict would disappear. Yet while neoliberal theory repressed the existence of class conflict, it also conducted a cammpaign against union power.

The attack on labour unions was an ideological assault because it involved an invocation of values in order to defame the accomplishments of the labour movement. Effective labour tactics were indicted as immoral. The method used to undermine unions was inversion. Neoliberal writers argued that labour's success was due to other causes, that victory would lead to failure and disaster, and that any success a union might have could only come at the expense of fellow workers. This inversion, this turning of the labour movement's greatest 
triumphs into a pretended catastrophe for the working class marks the neoliberal attempt to undermine the source of the labour movement's strength: solidarity.

One of the greatest accomplishment of the labour movement had been its ability to increase its members wages. Within state-led industrialization, consumption was encouraged for workers in the industrial sector to create a domestic market for the increased production of consumer goods. ${ }^{31}$ In principle, increased productivity would pay for both higher wages and higher profits while this virtuous circle also created a class of consumers capable of absorbing the increased production. Thus a union-led push for higher wages, forced capital to make capital investments to protect profit margins through an increase in productivity.

However, Hayek disparaged union success by asserting that higher wages for unionized workers came only at the expense of other workers who would have been willing to work at lower wages. Indeed, unions could only win higher real wages from an employer when they could use coercion to exclude others: "the employer will only agree to the wage when he knows that the union has the power to keep out others. ${ }^{32 "}$ Even when unions succeeded in raising nominal wages, they could not win because any wage rate above the level set by the market (the level at which no workers are left who would be willing to work for less), would only lead to inflation which would absorb the nominal

\footnotetext{
${ }^{31}$ Lipietz, 79.

${ }^{32}$ Hayek, The Constitution of Liberty, 270.
} 
surplus. ${ }^{33}$ Hence Hayek described union wage gains as a lose-lose proposition, for, if unions won higher wages, they did so only at the expense of fellow workers, and the wage increases they won would vanish anyway to inflation.

To Hayek, workers should fear their own success in gaining power through collective bargaining. In his view, unionization could only become universal by establishing sectoral monopolies which would then eliminate competition as the method by which resources are allocated. But monopoly would lead inevitably to totalitarianism, for, without competition, the only other possibility was socialist planning and control. Therefore Hayek stated that ... "(U)unionism as it now tends, however, to that very system of overall socialist planning which few unions want, and, indeed, it is in their best interest to avoid."34 Thus, according to Hayek, the power that workers had gained by unionization only threatened them with the loss of all power to the state and inevitably to totalitarianism.

Hayek also argued that union strength led to declining investment in those very sectors of the economy that were capital intensive and hence could lead to economic development. According to Hayek, unions were the strongest in capital intensive industries because these industries were the most vulnerable

33

Hayek, The Constitution of Liberty, 279-280. Hayek implicitly assumed static levels of productivity. He ignored the fact that increased productivity needed to be matched by an increase in the ability to consume and would also allow an increase in profits.

${ }^{34}$ Hayek, The Constitution of Liberty, 273. 
to union blackmail. Once they had invested heavily in machinery, these sectors could least afford an interruption in production. With this increased leverage, unions would increase their demands until unions could "practically expropriate the owner and command the whole return of his enterprise. ${ }^{\text {"35 }}$ Indeed, industry in concert with the unions could establish monopoly control, and hence prevent competition and improvements in productivity ${ }^{36}$ From a neoliberal perspective, unions threatened economic development instead of fostering capital investment to increase productivity to pay for increased wages and profits.

From the perspective of neoliberal theorists, the morality of the state's relationship with its own employees changed from good to evil. But to Friedman, good contracts for state workers were not a sign of fairness, but rather a symptom of corruption. According to Friedman, in cities where the taxpayer is loosely connected to the officials that sign contracts, the larger the city "the greater the tendency for officials and the unions to gang up at the expense of the taxpayer - another example of what happens when some people spend other people's money on still other people. ${ }^{137}$ This image denies the agency of the workers winning for themselves higher wages through bitter strikes. Instead, only a corrupt cabal of union leaders and corrupt officials could explain higher

\footnotetext{
${ }^{35}$ Hayek, The Constitution of Liberty, 270.

${ }^{36}$ Hayek, The Constitution of Liberty, 273.

37

Milton Friedman and Rose Friedman, Free to Choose (New York: Avon, 1979), 222.
} 
wages, and victory is transmuted into the wages of $\sin$.

Overall, these theorists conducted an ideological assault on unions through inverting their ethical case. Successes were turned into failures, long term hopes for the future were turned into threats against workers, and empowerment was dismissed as corruption. While neoliberal theorists attempted to undermine the legitimacy of unions in general, they also attacked specific union tactics. Here this approach was subtle; while union tactics were judged as illegitimate, the overall right to unionization was not dismissed. Instead the game of labour relations was to be rigged, with successful tactics banned for their offenses against neoliberal principles. Unions were still to be allowed, as long as they lacked the power to be effective.

Hence neoliberals attacked the value of solidarity by inverting it from a cause for celebration into something to be condemned. The inversion that took place was to change solidarity between workers into coercion against other workers. As Hayek argued:

The unions cannot achieve their principal aims unless they obtain complete control of the supply of the type of labour with which they are concerned; and since it is not in the interest of all workers to submit to such control, some of them must be induced to act against their own interest. ${ }^{38}$

Here Hayek, despite the historical record, implies that some members would have been better off if they could have bargained individually with management. Having defined solidarity as contrary to the interest of some individuals,

\footnotetext{
${ }^{38}$ Hayek, The Constitution of Liberty, 273.
} 
Hayek went on to describe the social mechanisms that maintained solidarity as coercive:

This may be done to some extent through merely psychological and moral pressure, encouraging the erroneous belief that unions benefit all workers. Where they succeed in creating a general feeling that every worker ought, in the interest of his class, to support union action, coercion comes to be accepted as a legitimate means of making a recalcitrant worker to do his duty. ${ }^{39}$

Thus all collective action can be delegitimated as inherently coercive and based on suppressing the rights of the individual. By this argument, solidarity as a class value leads to the oppression of the working class by workers.

One of the central tactics in any strike that supported union solidarity was the picket line. Workers who might be tempted to break solidarity during a strike and continue working were dissuaded from doing so by the presence of a picket line. Hayek described pickets as "instruments of intimidation," and said that "even so-called "peaceful" pickets are severely coercive. ${ }^{140}$ Hayek argued that we only accept picket line coercion, because we presume that the aims of unions are legitimate: " $t(T)$ he aura of legitimacy conferred upon it because the aims are often approved cannot alter the fact that it represents a kind of organised pressure upon individuals which in a free society no private agency should be permitted to exercise."41

Friedman also condemned closed or union shops. The theory behind

\footnotetext{
${ }^{39}$ Hayek, The Constitution of Liberty, 273.

${ }^{40}$ Hayek, The Constitution of Liberty, 274.

${ }^{41}$ Hayek, The Constitution of Liberty, 275.
} 
union shops was that they prevented free riding by non-members. All workers benefited from union contracts, and therefore all should pay their share of the costs by paying dues, joining the union and if need be, going on strike. Thus a closed shop meant that all workers shared equally in the costs of the union as well as its benefits.

But Hayek and Friedman argued that closed shops were "contracts in restraint of trade" ${ }^{\text {"42 }}$ or simply an attempt to impose union monopolies on labour which sins against free market competition. Friedman has argued for so called "right to work" legislation, legislation that bans closed shop contracts, or making union membership a condition of employment. Yet while to Friedman, it is an illegitimate infringement on liberty to require union membership, it is also perfectly legitimate to allow yellow dog contracts, contracts that make nonmembership in unions a condition of employment. ${ }^{43}$

While this position seems hypocritical, within the mind set of neoliberalism it is defensible. The moment of freedom was the moment an individual signed a contract with an employer. If an individual chose to sign with an employer a promise not to join a union, he or she had the freedom to do so, as all contracts, by definition, were the result of free choice. The infringement on liberty came only when the state sanctioned mandatory membership in a closed shop or allowed only union contractors to bid for contracts. If membership in a

\footnotetext{
${ }^{42}$ Hayek, The Constitution of Liberty, 275.

${ }^{43}$ Friedman, Capitalism and Freedom, 115.
} 
union was mandatory, then the employee could not choose whether or not they would join, and the employer lost control over whom they choose to employ. The principle was that, as long as individuals retained their individual right to choose, liberty was protected.

Neoliberal theorists also sought to ban union tactics of the secondary picket, and boycott. Both tactics relied upon broad allegiances from the general public to support the labour movement in other peoples' strikes. The implications of joining a boycott were profound. It was a personal act of solidarity with others for the action tied the individual to the group. Because the boycott supported a union, it implicitly involved recognition by the general public that unions were legitimate answers to problems of poverty and inequality. The boycott also relied on diffuse support for unions as organisations that had the legitimate right to call on the public's support in a conflict. Thus successful boycotts can be an effective tactic for unions in building the labour movement, as they created a space wherein private individuals could participate in a public act of solidarity.

But the neoliberal position again inverted boycotts and secondary pickets from an act of solidarity to an act of coercion. As Hayek stated "we must also regard as inadmissible methods of coercion all secondary strikes and boycotts which are used not as an instrument of wage bargaining but solely as a means of forcing other workers to fall in with union policies." ${ }^{34}$

\footnotetext{
${ }^{44}$ Hayek, Constitution of Liberty, 275.
} 
Hayek also proposed an end to unions' special status, their immunity from torts, civil liability and antitrust legislation. In his view the unions' immunity from liability for damages done during strikes was clearly a special privilege that no other organisation could claim. Since the hallmark of the rule of law was its universality, this too was illegitimate. ${ }^{45}$ If unions lost their immunity from liability, any strike would have bankrupted the union, since strikes were only effective if they did economic damage to the employer.

But the central and most dangerous demand for change in the labour movement was that union membership become completely voluntary. Voluntary not only meant that membership in a union was to be optional. The very nature of unions was to be changed into a service organisation, hopefully replacing the nefarious state social welfare provisions of workman's compensation. ${ }^{46}$ Members could decide that the union could negotiate contracts on their behalf, but those contracts would still be subject to ratification on an individual basis. Each individual worker could take advantage of the union contract or negotiate their own terms if they so desired. ${ }^{47}$ Employers and employees might decide to deal with conflicts between workers over relative compensation levels by following grievance procedures on a case by case basis. ${ }^{48}$

\footnotetext{
${ }^{45}$ Hayek, The Constitution of Liberty, 268-269.

${ }^{46}$ Hayek, The Constitution of Liberty, 277.

${ }^{47}$ Hayek, The Constitution of Liberty, 275.

${ }^{48}$ Hayek, The Constitution of Liberty, 277.
} 
This was a vision of union activities that served capital and, if implemented, would have destroyed union power. A voluntary union would lack the resources to pay for services rendered to the membership. Why pay union dues when the benefits of a union contract are available for free? Without universal membership and the threat of strike backing up union demands, why would any manager concede any gains at the bargaining table to a union? Without the strength that unity brought to a union, unions would lack the power to enforce their demands on businesses.

The central goal of the neoliberal assault on unions was the destruction of solidarity. First, neoliberal theorists undermined solidarity by recasting acts of solidarity into acts of coercion. Then, the tactics unions used to enforce and articulate solidarity were to be banned as coercive acts. The rituals of the union movement - the hiring hall, the picket line, the boycott and the secondary strike were to be banned as infringements on individual liberty. Having weakened unions by eliminating their tactics, these neoliberal theorists then sought to undermine solidarity by reducing the utility of union membership. By making union membership purely voluntary, non-members could reap the benefits of union contracts without paying dues, or indeed even having to lose wages during strikes. The neoliberal model for labour relations even offered managers the possibility of breaking the union through short-term bribery by making the provisions of a union contract only optional within the workplace. This left the possibility open for managers seeking to break a union to pay non-union members higher wages than their union brethren. Thus, this was an attempt to 
create a situation where workers could be set against workers, hence undermining the bonds of solidarity within the workplace, all in the name of individual liberty.

The annihilation of the union movement involved more than the simple elimination of a class enemy. It marked a recomposition of the organisation of work. Instead of labour discipline through union contracts, discipline would be imposed through atomizing workers and hence making the individual subject to the discipline of the employer. Thus, the assault on unions implied a reorganisation of the social relations of production in favour of capital accumulation.

The example of neoliberal discourse about labour unions in turn reveals the role that an ideology can play in the transition from one order to another. A new ideology (or more accurately a transforming ideology, since the precepts of neoliberalism, while extreme, were hardly new) undercuts the previous orders' norms through inverting its values from positive to negative.

For example, Hayek and Friedman inverted labour's core value of solidarity from a source of strength, dignity and empowerment to a source of coercion, fragmentation and exploitation. In terms of institutions, the role of the state in meditating labour conflicts was reevaluated from ensuring fairness and securing social peace to one that only guaranteed privilege for the few at the expense of other workers.

A transforming ideology goes beyond inverting the previous common sense of the old order to undermining its institutions in civil society. These 
institutions were not simply repressed or reformed for the space within which they were organised was also dissolved. The tactics and strategies which gave them strength and even successes under the previous order were then made illegal, impossible, or impotent.

In short, these institutions were disarticulated. The game, the system, within which they were established was dissolved. Union rhetoric, with its invocation of values resonated less and less with their supporters as it no longer reflected members' lived experience.

Thus Hayek and Friedman not only disparaged their enemies in the labour movement, they also undercut unions by rigging the rules of the games until the old tactics, the old rhetoric of the labour movement could not work. But more than just undermining the civil society actors from the old order, the transforming ideology provided the basis for an elite alliance dedicated to imposing the new order.

\section{Neoliberalism: Who Wins}

The philosophy of neoliberalism, as described by Hayek and Friedman, offered elites a rationale as well as a political project around which they could organise and then destroy their enemies. There is an affinity between neoliberal economics and the politics of its implementation. Neoliberalism as an ideology supports itself through the invocation of its own values which are then used to legitimate it as an economic and political model. These ideals can also be used to legitimate the elites' position to themselves, much like Weber's observation that the Protestant ethic was used to validate the position of the bourgeoisie. 
Thus, there was a practical affinity between the ideology of neoliberalism and the politics of implementing it: ideology justified and legitimated the system, while its policies reinforced its political position.

One of the general methods an ideology can use to secure the rule of an historic bloc is through the inculcation of a sense of fatalism in subaltern classes. As long as subaltern classes feel that rebellion against dominant classes is futile, then domination will not be challenged. Since government action is always wrong and market forces in the long-run produce the best result, the sensible reaction of the general population is not to bother with politics once government action is redefined as always futile.

Market order, in stark contrast, is based on the evolutionary forces of competition, and hence market outcomes are natural. Because market outcomes are natural, they exist beyond our judgement, beyond our will, thus . . . "conveying an air of inevitability and creating a naturalistic standard superior to human will by which to judge our behaviour."49 Once we agree that economic outcomes must only be left to nature, they, like the weather, become fate. If the economy is not subject to our political will, it is not a subject for political contestation. Whether or not fatalism is successfully instilled in the public, this principle justified both the elites' resistance to political demands from the masses and a counter demand by elites for political quiescence from the public,

49

Waligorski, 33. Of course markets themselves are the outcome of social forces that sanctify property relations. They are not class neutral but in fact reflect power imbalances. 
Neoliberal ideology is also practically useful because it legitimates the dismantling of civil society organizations that were based on demanding and receiving resources from the state. Neoliberal views justify the atomization of society into individuals since, according to the underlying premisses of neoliberalism, only individuals exist. Therefore, any organisations set up to take advantage of previous consensus building institutions are inherently illegitimate and should be dissolved. Thus, neoliberalism provides a justification for ignoring civil society organisations from the previous order.

Neoliberalism as an ideology contains norms and values that are politically useful in the legitimation of elites, elites that, in turn, ally themselves with the project of implementing the neoliberal economic model. Neoliberalism reflects the "interests" of the elites not only in a material way but just as importantly, in an ethical way by holding up the elites as the exemplars of virtue. Their virtue lies in their performance of their social role, a role that is at the root of their power.

One part of the elite that was held up as heroes by neoliberal ideology was the entrepreneur. The risking of all in the pursuit of profit created competition for labour, a competition that was believed to be the guarantor of liberty. ${ }^{50}$ Liberty, the highest value of the neoliberals, is best lived by the entrepreneur who invests his or her time and capital into an enterprise. The

\footnotetext{
${ }^{50}$ Hayek, The Constitution of Liberty, 124.
} 
profit, the wealth is the justified fruit of enterprise, the mark of victory in the marketplace. The celebration of the value and values of the entrepreneur by neoliberalism creates allies who see within neoliberalism what they value extolled as virtue (the pursuit of profit as freedom).

Neoliberal policy rewarded the bourgeoisie through the process of privatization. Since, according to this view, private enterprise is, by definition, more efficient than the state, large sectors of the economy were to be turned over to private capital. ${ }^{51}$ But once the state enterprise sector was dismantled and auctioned off, the new owners' material interest becomes tied up in defending the neoliberal project. Indeed privatization as a continuing project generates support as the bourgeoisie can always hope to benefit from the next round of privatization.

A second elite whose claims to power are legitimated by neoliberalism, are the neoliberal technocrats who are economists. Because the appetites of the masses lead to demands to interfere in the proper functioning of the market, the masses threaten liberty itself. In order to protect liberty, the economists who understand the market's needs, must establish and maintain good economic order independent of public opinion. Milton Friedman displayed this sense of the special character of his economists when he praised his Chicago Boys in Chile "as courageous men with a sense of dedication" while condemning other

\footnotetext{
${ }^{51}$ Waligorski, 153.
} 
bureaucrats for always seeking "better pay and perquisites for themselves." 52 Thus, within neoliberalism, the economist is portrayed as playing a heroic role, like the clergy of old, protecting the public from their sinful ways for their own good.

Neoliberalism, as an ideology, supported the political interests of its own elites. It instilled fatalism into subaltern classes by justifying the political insulation of its administrative elite from political pressure. It validated entrepreneurs as the true heroes of capitalism. But neoliberalism not only served the material and ethical interests of its elites, it also provided an affinity toward authoritarian actors that created a hegemonic bloc capable of imposing its rule through coercion.

\section{Neoliberal Ideology and Authoritarian Political Order}

Between neoliberalism and authoritarianism lies a shared set of premises that underlies their ideological affinity. Both share anti-democratic principles and the sense that the demands of civil society are inherently illegitimate. Inherent greed meant that democracy had to be restricted in scope to keep the state to a limited set of functions.

The means by which neoliberal technocrats proposed to emasculate democracy was through embedding their model of a restricted state and

52

Elton Rayack, Not so Free to Chose, (New York: Praegar, 1987), 74. Rayack pointed out this contradiction. 
economic policies in constitutions. Because politics is driven by the avarice of special interests, according to neoliberal theory, politics threatens to overwhelm the market and hence threaten liberty. Therefore the correct economic policies must be imposed by incorporating them into constitutions to place economic policy above and beyond demand-driven politics.

The fear and disdain for political interference in setting economic policy, leads to a crucial affinity between neo liberal technocrats and key supporters of authoritarian political solutions: the military. Both share an attitude towards democratic politics, which has been described by Loveman and Davies as the "politics of anti-politics." As Loveman and Davies argued, the Chilean military despised politicians as those who create conflict and corruption to gain support. Hence democratic politics were not about finding compromises, developing consensus, or creating consent, but were instead about the pursuit of the spoils of office. Thus, neither democratic politicians nor democratic politics were legitimate, necessary or useful. Instead, politics and politicians were the cause of conflict. The solution for the military was to overthrow democratic governments and institute an authoritarian regime.

Neoliberal technocrats shared this anti-politics with the authoritarians of the military. They shared a rejection of redistribution as only a source of corruption. However military actors condemned redistribution as moral corruption, while

53

Brian Loveman and Thomas M..Davies, Jr., The Politics of Antipolitics: The Military in Latin America (London: University of Nebraska Press, 1989), 4-5. 
neoliberals condemned it as a corruption of the natural order of the market.

This precedence of the market over politics that is at the heart of neoliberalism, leads to such a restricted vision of the possibilities of politics that neoliberal political order closely resembles that of an authoritarian order. Like authoritarianism, the independent pressures of civil society are deemed inherently illegitimate and only a self-serving attempt to corrupt the state for one's own benefit. Once the state is banned from both its directive function over the economy and any redistributive role, the functions that are left are only administrative - the state simply provides adjudication and rule enforcement without any political choices left to be made. In this way, politics in a neoliberal nation, would become apolitical, with all choices removed and turned over to the market. Once politics loses its content, then elections become a mere matter of choosing the best administrator, the best person to oversee the smooth functioning of the market.

Yet it is this content-free vision of politics that offers the authoritarians their greatest hope, a society free from all conflict. All conflict has been politically silenced by being transferred to the market. Once the people accept that their liberty depends on a complete acceptance of the justice of market distribution, then all social and class conflict will cease. Thus there is an affinity between the dreams of neoliberal thought and authoritarianism, a society without conflict.

\section{Conclusions}


Beyond a dream of a society where conflicts over resources have vanished by banishing collective goals to the vagaries of the market, the question remains: did neoliberal theorists offer an ideological vision that would allow a Caesarist dictator like Fujimori to reorganise Peruvian society?

What neoliberal writers offered was an ideology that was the antithesis of the previous order of state-led industrialization until what was good was redefined as evil, and what had been purpose was redefined into what must be avoided at all costs. Neoliberalism justified the dissolution of the previous order's social relationships from the individual's relationship to society, to the sense of collective identities, to the state's relationship to society, to the purposes of the state, to how relationships are structured in the economy.

But if Fujimori destroyed the old, what was the utopian vision that neoliberalism offered instead? In terms of economic relationships, neoliberal technocrats proposed to create a flexible and atomized workforce open to market forces. The relationship between the state and society was to be irrevocably changed for the state could no longer address economic inequality and market failures. The state was to lose all of its twentieth century expansion in welfare duties and be reduced to a nightwatchman state.

In order to develop this vision of a utopia of a happy market society, neoliberals had to ignore issues of class and class conflict. This silence indicates that transforming ideologies in general are about faith and not facts, function and not truth. To ignore the existence of class and class conflict beggars understanding unless transforming ideologies are based on belief 
systems and not reality, on what Habermas described as counterfactual truths. Believe that class does not exist, then one does not have to redress inequality to reduce class conflict. But this also means that transforming ideologies are not judged on the basis of their heuristic utility or on the results of their policy prescriptions; they are instead selected because they perform the functions required of an ideology in the transformation of an order.

Neoliberal thought provides us then with an example of the functional requirements of any transforming ideology. These ideologies must dissolve the ethical basis of the previous common sense, of the ethic that provided the moral basis for the previous order. These ethics are overturned not merely through ignoring them or refuting them, but by inverting them, by reversing good and evil.

New social forms and institutions must be created that embody the new common sense. Thus new more flexible unions must replace the old classista unions if the social space of the labour movement is to be transformed and not merely repressed as usual. The old state formation that emphasized the protection of the unionized fraction of labour to create a consumer class had to be replaced by a new constitutional structure that isolated the state from political pressures from subaltern classes.

The new ideology must also legitimate new patterns of domination. A new model of heroism must be celebrated to reflect the values that define new dominant elite. The entrepreneur is the new hero, the new creed is greed. The new ideology must support and reflect the material interests of this new historic 
bloc by justifying a new state to serve them and new relations of production that reward them. In sum, the function of a transforming ideology is to bury the old order while acting as the intellectual midwife of the new.

In terms of the individual's relationship to society, neoliberalism is based on an ontology that extols the desires of the individual while it denies the possibility of any collective purposes. Since no collective purpose is possible, then the collective struggles of the twentieth century for equality, for social justice are written off as camouflage for individuals extorting privileges from everyone else. Instead of seeking a democratic consensus, neoliberals longed for an authoritarian order that would protect the market from democratic pressures.

But to attempt to map out the affinities between a dictatorship and neoliberalism requires more than simply describing how neoliberalism undermined the values of equality and social justice that had driven the agenda of civil society. It must also be demonstrated how the ideology of neoliberalism supported the political aspirations of Fujimori, and his establishment of a dictatorship, which is the subject of the following chapter. 


\section{Chapter Three: Fujimori and the Technocrats}

\section{Introduction}

When Fujimori won office in 1990, he faced a massive crisis of accumulation, hegemony and representation. If Peru was to survive, he had to institute a comprehensive restructuring of the Peruvian economy, state, and society. The Peruvian economy and political system of representation had imploded, taking along with it the ideology of economic populism and state-led industrialization. Yet no nascent class had the political strength to impose a new political order, a new economic structure and hence a new hegemonic ideology that would have legitimated the new arrangements. Instead Fujimori, as a Caesarist dictator, imposed a new order.

Neoliberalism offered an ideology that justified the dismantling of the previous order. Because of the strong anti-state bias of neoliberalism, its arguments could be used to legitimate the dismantling of the state-owned enterprise sector through privatization. Neoliberalism also offered an excuse for the abandonment of large areas of responsibility by the state. Unfortunately, the Peruvian state had not proven capable of actually delivering services in these areas. But what neoliberal thought did was change the subject from how to reform delivery of service to make it more effective, to simply withdrawing from an area. Neoliberalism also offered a rationale for dismantling the power of the labour movement. The combination of an indifferent state and weakened unions left subaltern classes without a site or agents to organise resistance. 
While the previous chapter examined how neoliberalism as an ideology supported transformation, this chapter is an examination of how the personal desire of Fujimori for an authoritarian political order also fulfilled the needs of this political conjuncture, this Caesarist moment. Even though the old order had failed, its beneficiaries - politicians, civil servants, owners and managers of industry, and members of unions who were protected by the labour code - were all prepared to act in its defence.

Note that the bourgeoisie were compromised by their relationship to the old order, dependent on exemptions and subsidies for their profits and their very survival. So while as a class they had generally supported Vargas Llosa because of his defence of banks against expropriation by Garcia, they still demanded individual exemptions and special treatment for themselves. Thus habitual corruption diluted the voice of the bourgeoisie.

The new neoliberal order then created a different kind of bourgeoisie, one less dependent on government favours than on their ability to move between the formal and informal markets. For example, reducing tariffs on automobiles and eliminating state regulation of the taxi and bus sector created a new class of bus and taxi owners and operators. Since this group was created by these reforms it cannot predate them. Thus there was no group of beneficiaries whose identity and material interests were tied up with neoliberalism until neoliberal policy reforms created them.

Since Fujimori did not represent an insurgent bourgeoisie, who did Fujimori serve? Did Fujimori's dictatorship have an affinity to the needs of 
transformation? Did neoliberal reforms have an affinity towards the establishment of an authoritarian regime? Did neoliberal reform set the project around which various authoritarian actors and groups ally?

Beneath Fujimori's authoritarianism lay a profound distaste for political parties whose corruption had led Peru into a catastrophe. On one level, Fujimori's contempt for political parties meant that he refused to found a new political party to support his government that was autonomous from his personal political career. This meant that his political movements did not represent the growing social stratum of the informales, one of his major bases of support (see Chapter One). But the political result was that his supporters in Congress were a collection of political neophytes and unknowns who relied exclusively on Fujimori for their position and were not selected by a mass membership or independent leaders from other organizations. Thus these new members of Congress did not organically represent anyone. Their dependence on Fujimori meant that Congress failed to provide any check to his power. His contempt for the old political elite also resulted in the autogolpe of April 1992, when Fujimori dissolved the institutions of the state and created a new state formation, one that let a Caesarist dictator rule unfettered by social forces.

Behind Fujimori's reforms lay a cadre of neoliberal technocrats willing to staff his cabinet and create the reforms. This chapter will examine the underlying affinities between Fujimori, technocrats and neoliberalism. Fujimori's taste for neoliberalism lay in its justification for the centralization of power. Technocrats, in turn, provided Fujimori with a revolving cadre of officials without connections to 
the previous order, eminently capable and easily disposable. For the technocrats, dictatorship provided the opportunity to reshape Peru without hindrance. The attitude of these neoliberal technocrats to unions will also be examined as an example of their opinion of civil society organisations of the previous order. This will help us understand how the dissolution of old ideas of justice was justified. But underneath it all lay neoliberalism as the project that united the military, Fujimori and the technocrats in a ruling coalition to reshape Peru.

This chapter draws together the conclusions derived from the first two chapters, to understand how a Caesarist leader like Fujimori would find in neoliberalism a solution to his society's political and economic impasse. This chapter further develops the concept of a Caesarist leader from chapter one, by demonstrating how neoliberal technocrats as a group could serve and be served by a Caesarist leader. This chapter builds on Chapter Two to demonstrate how the ideological notions of neoliberalism were useful for an outsider to justify the dismantling of a failed political, social and economic order. Neoliberalism was the project that justified Fujimori's dictatorship. The subject of this chapter is why once Fujimori had chosen to implement neoliberal reforms, that choice would support his authoritarian leadership style and support his implementation of a dictatorship.

\section{Caesarism}

While Fujimori constructed a dictatorship, the question is, did this political moment need a dictatorship? Was the impasse of political forces really so dangerous that only a resolute dictator could resolve this crisis? The crucial 
characteristic of Caesarist regimes, according to Gramsci, was that they govern from outside the current impasse of social forces. The dictator imposes a solution from above, authors a new institutional order and imposes a new relationship of forces or class structure without consultation or compromise:

Caesarism - although it always expresses the particular solution in which a great personality is entrusted with the task of "arbitration" over a historical-political situation characterized by an equilibrium of forces heading towards catastrophe. ${ }^{1}$

The characteristic form of this Caesarist state was that all power was centralised in the hands of the dictator unchecked by precedents, previous institutions or constitutional structures. Indeed, centralization was not just a reflection of the personal vanity of the leader; it was a reflection of the failure of previous structures and norms to control conflict and impose order. The dictator dissolved these old structures, and created new ones to facilitate the birth of new relations of production despite the resistance of organisations within civil society from the old order. Centralization made possible a transformation in relations of production, in the mode of regulation and the regime of accumulation. ${ }^{2}$

Antonio Gramsci, Selections from the Prison Notebooks of Antonio Gramsci, ed. Quintin Hoare and Geoffrey Nowell Smith (New York: International Publishers, 1971), 219.

A regime of accumulation refers to a specific kind of system of the accumulation of surplus value. Each regime utilizes a different division of productive forces between the accumulation and consumption. See Alain Lipietz, Mirages and Miracles: A Crisis in Global Fordism (London: Verso, 1987), 14. A mode of regulation refers to the institutions and the habitual actions they create which reproduce the regime of accumulation. Lipietz, 33. 
The reason that a dictator was required to dissolve the old institutional structures was that they had power, power that could be used to veto their own dissolution. According to George Tsebelis, nations have institutions which are capable of vetoing reforms that threaten their interests. ${ }^{3}$ In normal times, these institutionalized veto points serve to limit conflict and hence stabilize the system. But in a crisis situation these veto points must be suspended in order to reform institutions and dissolve the routinized patterns of domination they represent. The Supreme Court, the Constitution and the Congress were all dissolved in order to eliminate vetoes from interests affected by reform. For example, in Peru the Constitution of 1979 enshrined labour rights including universal life long job tenure. These rights represented the balance of forces in Peruvian society at this conjuncture, but had to be eliminated for a transition to the new neoliberal order. Our understanding of the need for a dictator who could impose a new order from outside can be developed through Guillermo O'Donnell's construct of a delegative democracy. O'Donnell's work is centred in the concrete and current cases of structural adjustment in Latin America. This concept's major limitation was that it was conjunctural rather than structural in nature. He noted that presidents in the region had been delegated the authority to impose change in a time of crisis, without examining its causes or noting just how much these delegative regimes transformed in society.

Leslie Elliot Armijo and Phillipe Faucher, "We have a Consensus': Explaining Political Support for Market Reforms in Latin America," Latin American Politics and Society 44, no.2, 21. 
He argued that electorates had turned power over to a series of presidents who had imposed structural adjustment policies from outside despite whatever they had promised during elections. O'Donnell defines delegative democracies as follows:

Delegative democracies rest on the premise that whoever wins election is thereby entitled to govern as he or she sees fit, constrained only by the hard facts of existing power relations and by a constitutionally limited term of office. The president is taken to be the embodiment of the nation and the main custodian and definer of its interests. The policies of his government need bear no resemblance to the promises of his campaign - has not he been authorized to govern as he (or she) thinks best? Since this paternal figure is supposed to take care of the whole nation, his political base must be a movement, the supposedly vibrant overcoming of the factionalism and conflicts associated with parties. ${ }^{4}$

O'Donnell's formulation expressed some of the key requirements of a Caesarist regime: the unfettered authority of the leader over the direction of policy without regard to either political parties or public opinions or even their own promises to the electorate. Their duty was to govern and reorder, not develop democratic consent for that new order. Most of these leaders did not explicitly overturn democracy by suspending the constitutional order like Fujimori. But their disregard for public opinion, their running roughshod over legislative or judicial opposition, their willingness to overturn all precedent meant that while their rule might be sanctioned by elections, it was not democratic. Their rule marked the overcoming of old outmoded divisions and conflicts by fiat not negotiation.

Guillermo O'Donnell, "Delegative Democracy" in The Global Resurgence of Democracy, $2^{\text {nd }}$ edition, ed. Larry Diamond and Marc Plattner (Baltimore: The Johns Hopkins University Press, 1996), 98-99. 
The centralisation of power into the hands of the executive occurred across countries that underwent structural adjustment programmes. As Henry Veltmeyer, James Petras, and Steve Vieux observe, the retrenchment inherent in structural adjustment policies reduced the resources available to parties and hence dissolved the linkage between political parties and lo pueblo. Class support for mass political parties across Latin America were founded on the redistributional policies of state-led industrialization. ${ }^{5}$ Hence when an economic crisis bankrupted the state and disrupted employment, it disarticulated the bases for loyalties to particular parties. Indeed, the downsizing of the state reduced its salience for lo pueblo, and hence de-politicized the public, which further insulated the executive from popular demands. ${ }^{6}$ Because of the speed and secrecy necessary for the implementation of shock policies, executives across Latin America imposed SAPs by decree instead of through Congress in legislation. Without a deliberative role to play in the formulation of policy and without a representative role because of the disarticulation of the parties, congresses across Latin America became mere "talking shops".

\footnotetext{
5See David and Ruth Collier, Shaping the Political Arena (Princeton: Princeton University Press, 1991) for the history of how redistribution and organizing unions acted as the vector for the incorporation of the masses into Latin American politics.

${ }^{6}$ Henny Veltmeyer, James Petras, and Steve Vieux, Neoliberalism and Class Conflict in Latin America: A Comparative Perspective on the Political Economy of Structural Adjustment (London: MacMillan Press Ltd., 1997), 57.

${ }^{7}$ Veltmeyer, Petras, and Vieux, 68-69.
} 
The diminution of the independent power of the legislatures and the judiciary meant that the president could impose changes without democratic checks on his or her power. As Guillermo O'Donnell noted, this meant that the president owed no horizontal accountability to other branches, and no judge nor legislature was able to interfere with the president's mission to reconstitute the nation. $^{8}$

This lack of horizontal accountability reflected the need for a Caesarist dictator to resolve the impasse between social forces without hindrance. In Gramsci's phrase, the situation is one wherein "the old is dying and the new cannot be born". ${ }^{9}$ In order to impose the new, the Caesarist dictator must be left unimpeded by other branches. The legislature is reduced to a talking shop without power, the judiciary purged and brought to heel. Democracy is replaced by autocracy.

What Gramsci adds to our understanding of this situation is that the need to reform political institutions noted by O'Donnell had a structural mission that extended beyond the political. This meant that new institutions were required that articulated a different balance of power in the workplace(see Chapter Six). A new labour code had to be created that would reproduce the new neoliberal relations of production based on flexibility and precarious employment. Political institutions had to be not only purged of the corrupt, they also had to be reconstituted so

O'Donnell, 100-101.

Gramsci, 276. 
they could reproduce a new mode of regulation, reflect a new regime of accumulation and its new legitimating ideology.

In the Peruvian case, the crisis of representation was separated from the imposition of neoliberalism. The state had already collapsed and the parties had imploded (see Chapter One) before the imposition of the new political order. Therefore, the turn to authoritarianism under Fujimori had less to do with the need to repress old parties than with an affinity for authoritarianism inherent in the Caesarist process of transforming a society.

\section{Fujimori as the Autocrat}

Whether or not political leaders have authoritarian tendencies is usually of little moment. In a stable democracy, authoritarian leaders are constrained by democratic institutions and either conform to democratic norms or are impeached or removed. Conversely, during a crisis of hegemony, a leader who attempts to govern democratically may simply be ineffective. Those interests that had prospered under the previous order would have possessed linkages to institutions within the state, institutions that possessed the formal power to utilize what George Tsebelis described as veto points to protect the status quo. ${ }^{10}$ Formal institutions in this case included Congress and the judiciary before the autogolpe. 
However, the official institutions of Congress and the judiciary were not the only forces that possessed the power to veto changes. Other forces also had an effective veto through their capability to destabilize the situation and hence overthrow the government. The private sector could threaten chaos through capital flight like they did to Garcia. The military could threaten a coup if its interests were threatened by human rights investigations. The IFl's could threaten Fujimori by just withholding their imprimatur on his policies, hence continuing the economic crisis (see Chapter Four). Historically, the labour movement had exercised its veto by calling general strikes to destabilize governments, but this veto that had vanished under Fujimori (see Chapter Six). By the time Fujimori entered office, the forces in civil society that might have vetoed neoliberal reforms had lost their power, while the other forces from the military to the bourgeoisie and the IFls all supported reform in their own interests. Those who had formal vetoes, were dissolved by the autogolpe.

The crisis that faced Peru in 1990 dictated a suspension of normal, democratic consultation. Juan Carlos Hurtado Miller, Fujimori's first Prime Minister and Minister of the Economy, reflected this justification for undemocratic behaviour in times of crisis when he said, "In the management of politics in these moments of crisis, it is necessary that inside the government there is an element of dictatorship, since there is no time and no space for negotiations."11 Solutions

\footnotetext{
${ }^{11} J u a n$ Carlos Hurtado Miller, quoted in Pilar Dávilla Pérez, "La visión de los implementadores de políticas," in Implementación de Políticas Públicas en el Perú, ed. Augusto Alvarez Rodrich and Gabriel Ortiz de Zevallos (Lima: Apoyo, 1995), 170. Translation by author.
} 
had to be imposed without consultation, according to Miller, since there were no resources for accommodating civil society actors, nor was there time to build a consensus.

Fujimori wanted to go beyond short term solutions. He wanted the power to resolve Peru's problems without hindrance for an extended period of time. Early on in his administration in 1991 in an address to the national business conference for executives, he argued that Peru needed to have " an emperor, one who will expend at least ten years solving the nation's problems." ${ }^{12}$ Note that this was before the autogolpe when he was still constitutionally limited to one term of five years. After the autogolpe, Fujimori defended his regime against the accusation of authoritarianism by stating .... "My Government has been labelled authoritarian ... but exercising order and authority should be normal in a civilized society, in a society that wants to advance. It is abnormal for disorder and anarchy to prevail." ${ }^{13}$ According to Fujimori, order absolved him from all sins.

Fujimori's impatience with Congressional opposition was at least consistent with his publicly expressed opinions of all of the old-line parties. He accused the parties of creating a partidocracia, a corrupt oligarchy of political elites whose greed, corruption and incompetence had led Peru to the edge of the abyss. According to Fujimori, political parties did not perform a representative

Fujimori, quoted in Francisco Durand, "Business and the Crisis of Peruvian Democracy," Business and Politics 4, no. 3, (2002), 325.

13

Fujimori, quoted in Durand, "Business and the Crisis of Peruvian Democracy," 326. 
function by articulating demands from groups that supported them. Instead parties were only collections of individuals seeking their turn at the trough of the state. He proposed to represent personally and directly all Peruvians:

En el Peru no existen partidos politicos (...) El Poder soy yo, es verdad. Pero es un poder que me fue dada por el pueblo. Yo lo represento. (In Peru there are no political parties. It is true that the power is mine. But it is a power that has been given to me by the people. I represent them.) ${ }^{14}$

However, Fujimori's contempt was not limited to the old line parties; it extended to all political parties including his own. During his time in office, Fujimori constructed four different political vehicles to support him: Cambio 90 (Change 90), Nueva Mayoría (New Majority), Vamos Vecinos (Let's Go Neighbours) and Perú 2000. Cambio 90 was his original party vehicle. Nueva Mayoría was formed by Jaime Yoshiyama to contest the Constituent Assembly elections of 1993 as a vehicle for the technocrats within the administration. Vamos Vecinos was the municipal wing of the Fujimori organization and was designed to compete with Alberto Andrade's Somos Perú in municipal elections..$^{15}$ Perú 2000 was the last vehicle for Fujimori, designed to integrate the three previous formations into one movement.

\footnotetext{
${ }^{14}$ Quoted in Aldo Panfichi and Cynthia Sanbourn, "Fujimori y Las Raices del Neopopulismo," en Los Enigmas del Poder: Fujimori 1990-1996, 41. Translation by author.

${ }^{15}$ Alberto Andrade was the Mayor of Lima in the late 90's. He was considered to be the foremost opposition candidate for the elections in 2000 . His movement Somos Peru, was a coalition of political notables and municipal politicians, and was the basis for a political machine for the elections in 2000. Vamos Vecinos encouraged defections from Somos Peru through intimidation and bribery.
} 
But none of these movements existed independently from Fujimori. There were no mass memberships, independent party hierarchies, or consultative structures. The Peruvian Congress was selected through proportional representation a unified national vote. The total number of seats per party was determined by the total number of votes each party received. Each party determined the rank order of their Congressional candidates, though candidates could move up the list by receiving more preferential votes than the others on the list (indicated by the elector by writing the number of the candidate in the spot for their vote). Indeed the existence of different movements sponsored by Fujimori enabled him to keep all these organizations in line, since he could play one off against the others with the final prize of rank order for Congress, firmly in his grasp. Indeed, Cambio 90 had little to no influence over Fujimori, and, in the six months preceding the autogolpe, the entire cabinet was composed of independents. In contrast, both García and Belaúnde's cabinets were dominated by their parties. ${ }^{16}$ Fujimori also dropped the majority of those elected on the Cambio 90 list in favour of members of the Nueva Mayoria in the elections for the Constituent Assembly. ${ }^{17}$ Fujimori controlled his movements; the movements had no control or influence over Fujimori.

\footnotetext{
${ }^{16}$ Cynthia McClintock, "La voluntad política presidencial y la ruptura constitucional de 1992 en el Peru," in Los Enigmas del poder: Fujimori 1990-1996, ed. Fernando Tuesta Soldevilla (Lima: Fundación Friedrich Ebert, 1996), 60.

17 Pedro Planas, "Existe un Sistema del Partidos en el Peru," en Los Enigmas del Poder:Fujimori 1990-1996 (Lima: Fundación Friedrich Ebert, 1996), 195. Constituent assembly elections were held in November 1992, with the new constitution passed by plebiscite in November, 1993.
} 
Fujimori's utilized a populist style, connecting with the people without any mediation. He spoke directly to the people via television and interspersed his speeches with jokes and colloquial phrases. He directly contacted those lost in the hinterland by flying into remote villages to offer goods and services personally, all broadcast on the nightly national news. ${ }^{18}$ This gift giving by the President was described as techno-populism, because Fujimori distributed computers and satellite dishes. Yet gift giving resonated with traditions in Peruvian political culture, where the local political leaders would distribute gifts of food and pisco (a kind of brandy native to Peru), to maintain their relationship with the local population. ${ }^{19}$ Fujimori's actions were in direct contrast to those of previous presidents who promised the moon while delivering disaster. Fujimori promised little, but actually delivered gifts, stable inflation and the defeat of Sendero.

Here it is useful to note that Fujimori fulfilled several of Robert's criteria for a populist leader. He utilized an anti-establishment discourse and insisted on a direct connection to the excluded without mediation. ${ }^{20}$ Unlike classic populists, he dissolved organizations instead of incorporating excluded sectors like industrial

\footnotetext{
${ }^{18}$ Patricia Oliart, “'A President Like You': Fujimori's Popular Appeal", NACLA Report on the Americas XXX, no. 1, 18-19.

${ }^{19}$ Carlos Ivan Degregori, Jose Coronel, and Ponciano del Pino, "Government, Citizenship and Democracy: a Regional Perspective", in Fujimori's Peru: The Political Economy, ed. John Crabtree and Jim Thomas (London: Institute of Latin American Studies, 1998), 245.
}

${ }^{20}$ Kenneth M. Roberts, "Neoliberalism and the Transformation of Populism in Latin America: The Peruvian Case," World Politics 48, no.1 (1996), 88. 
workers or the indios. Fujimori's neo-populism relied on direct gifts from his own hands to create a material base for his support.

Not only was all loyalty and gratitude directed towards Fujimori as a person, but so too was all power. Decisions were not made collegially by the cabinet as a whole. Instead, the nucleus of decision making rested in the hands of Vladimir Montesinos and Fujimori's brother Santiago. Vladimir Montesinos was a shadowy figure who controlled the intelligence agency, and latterly the Armed Forces. His exposure in a corruption scandal in $\mathbf{2 0 0 0}$ resulted in Fujimori's fall from power (see Conclusion). These two controlled access to the President and handled the relationships with the armed forces and the press respectively. ${ }^{21}$ Because the President was personally in charge of reform, his cabinet ministers had no authority over the institutional reforms to programs in their own ministries. For example, Fujimori was personally engaged in making the key decisions in the reforms to all social programs. ${ }^{22}$ Because cabinet ministers lacked political prestige (after the first cabinet, Fujimori's cabinet ministers lacked previous political experience, or were technocrats), Fujimori monopolized political power and decision-making. Cabinets did not deliberate and design policy collectively, they merely endorsed already existing plans. ${ }^{23}$ Indeed some of the crucial

\footnotetext{
${ }^{21}$ Planas, 195.

${ }^{22}$ Gustavo Guerra García, "Los programas de compensacíon social en el Perú: 1990-1992," en Implementacíon de Póliticas Publicas en el Perú (Lima: Apoyo, 1995), 68.

${ }^{23}$ John Crabtree, "Neo-populism and the Fujimori Phenomenon," in Fujimori's Peru: The Political Economy, ed. John Crabtree and Jim Thomas (London: Institute of Latin American Studies, 1998), 17.
} 
political decisions that Fujimori made, like the autogolpe and the attack on Baruch Ivcher ${ }^{24}$ were made without consultation or prior warning to his own cabinet.

Civil service inertia did not provide a counter balance to Fujimori. Appointments to the Peruvian state followed the American model with all the top levels of the bureaucracy directly appointed by the President, which meant that the civil service lacked a leadership cadre committed to the state's permanent interest. Civil servants also lacked political credibility, since both the Belaúnde and García governments had packed and padded the state with patronage appointees (see Chapter One). Now the permanent staff of the civil service was confronted with a President determined to downsize and reform the state. Their jobs depended on predicting the priorities of the President and "in many cases the primary objective of civil servants was to avoid conflicts with the President, in order not to prejudice the development of their careers within the government."25 Thus, downsizing terrorized the permanent civil service into paralysis and an uncritical obedience to Fujimori's wishes.

Whatever the structural requirements were for the foundation of a new order, whatever the requirements were of that political moment, those who had contact with Fujimori thought that he was personally authoritarian. Carlos Amat $y$ Léon, Fujimori's first agriculture minister, thought that Fujimori was

The attacks on Ivcher were undertaken without discussion by cabinet, according to interviews.

${ }^{25}$ Guerra Garcia, 68. 
psychologically incapable of working collegially with his cabinet to achieve consensus $^{26}$. Fujimori's authoritarian preferences were revealed when Professor Amat y Léon's deputy minister had achieved a consensus with all stakeholders on reforms for the agricultural sector. Fujimori told Amat y Léon that agrarian reforms were to be imposed not negotiated, and demanded that Amat y Léon fire his deputy. Amat y Léon refused and became the first technocrat fired by Fujimori. ${ }^{27}$ In Fujimori's Peru, decisions were imposed by the will of the President, not arrived at through democratic compromise or negotiation. Guido Pennano, another ex-cabinet minister declared that to Fujimori: "authoritarianism for authoritarianism's sake was a value." ${ }^{28}$ Fujimori personally preferred authoritarian power structures and created new political structure that reflected his taste. That Fujimori acted dictatorially out of personal preference was beyond dispute, but what was of crucial political importance was that he constructed a new political order.

\section{The Eighteenth Brumaire of Alberto Fujimori: The Autogolpe as a Caesarist coup}

\footnotetext{
${ }^{26}$ McClintock, 66.

${ }^{27}$ Interview with Carlos Amat y Léon, July 1997. Professor Amat y Léon was also an unusual technocrat in Fujimori's regime, in the sense that he was a prominent political figure prior to joining Fujimori's cabinet. He had been a vicepresidential candidate in 1990 on the IU ticket. He was also quite proud of the fact that he was the first technocrat fired by Fujimori.
}

${ }^{28}$ McClintock, 66. 
The political moment that marked the dissolution of the old order and the beginning of a dictatorship was the autogolpe. While the debate in the literature centred on either Fujimori's personal predilection for dictatorship or political need to eliminate the opposition, this thesis uniquely offers a study of the structural requirements answered by the autogolpe of April 1992. The autogolpe was not merely an attempt by Fujimori to cement his personal power, it was also part of a Caesarist mission to rewrite Peru's political institutions. What was needed was not merely a suspension of constitutional checks on the president, but a rewriting of the constitution. A new political arrangement was required that would reinforce the new neoliberal order.

However, despite Fujimori's claims of necessity to justify the autogolpe, institutional actors had not blindly obstructed Fujimori's attempts at reform. Before the autogolpe, opposition parties had a majority in Congress. While Congress had blocked some reforms, for the most part Congress approved Fujimori's economic and political package.${ }^{29}$ Congress approved $78 \%$ of Fujimori's decrees promulgated in the decretos-bombas of November 1991, versus $22 \%$ that were either modified or annulled ${ }^{30}$. However, the decrees that were either modified or annulled dealt with security issues, and thus alienated the

\footnotetext{
${ }^{29}$ Maxwell A. Cameron, "The Eighteenth Brumaire of Alberto Fujimori" in The Peruvian Labyrinth: Polity, Society Economy, ed. Maxwell A Cameron and Phillip Mauceri (University Park, Pennsylvania.: Pennsylvania State University Press, 1997), 54-58.

30 McClintock, 64. The Decretos-Bombas were a package of 126 decrees promulgated by Fujimori that involved the complete reorganization of the economy and the state.
} 
military. But even though Congress was only performing its democratic duty of providing a check on presidential power and upholding the rule of law, President Fujimori was infuriated. He refused to sign a compromise budget negotiated by his economy minister and Congressional leaders. ${ }^{31}$ Fujimori seems to have been personally incapable of accepting the normal give and take of democratic politics.

However, within the government, there was a growing sense that the opposition was organizing itself in Congress to block reforms. The problem for Fujimori was that the state's institutions were packed with Alan Garcia's Aprista appointees and Garcia was beginning to use his followers to sabotage institutional and economic reform. The Constitutional Tribunal ruled unconstitutional one of the key labour market reforms, the Law to Increase Employment, which would have ended life time job security. ${ }^{32}$ The Apristas were also using the Congressional Comision de Economía to remove Fujimori's power to increase taxes, by insisting that all increases be passed by legislation rather than by decree. Carlos Boloña, the Finance Minister, accused the "alanistas" of playing games, seeking to veto an increase in sales taxes which would have undone reforms in tax collection. ${ }^{33}$ After the autogolpe, Boloña argued that there had been a growing risk of institutional paralysis with an

\footnotetext{
${ }^{31}$ Deborah Poole and Gerardo Renique, Peru: Time of Fear (Latin American Bureau: London, 1992), 158.

${ }^{32}$ Carlos Torres y Torres Lara, Los Nudos del Poder (Lima: Dessarollo y Paz, 1992), 93-95. Torres y Torres Lara was a cabinet minister under Fujimori.

${ }^{33}$ Carlos Boloña, Cambio de Rumbo (Lima: Instituto de Economia Libre Mercado, 1995), 94.
} 
opposition that "had not demonstrated that it had given up its old mercantilist ways." ${ }^{34}$ Boloña feared that Garcia's power was increasing daily, and he was prepared to destroy Peru to refloat his failed populist project. ${ }^{35}$ Torres y Torres Lara observed that while Fujimori could not constitutionally dissolve Congress, Congress could easily impeach the President on the vague grounds of "moral incapacity". ${ }^{36}$ Meanwhile, Maximillo San Roman, the First Vice President, who was seen by the opposition as being more amenable to negotiation, was busy enhancing his image and making himself look like a possible president. ${ }^{37}$

The underlying cause of the autogolpe was not institutional gridlock but the perception of a future institutional block that might prevent the fundamental reforms required to change this order. The purpose of structural adjustment was not merely to make state-led industrialization work better, but to alter fundamentally and radically everything to usher in a new age of neoliberalism. In this context, seemingly modest modifications to the economic package to reduce taxes or support a sector might threaten the goals of the entire program. In November 1991, Congress passed a Law of Agricultural Emergency, a spending bill of exchange and tax subsidies for the agrarian sector that would cost $\$ 300$

\footnotetext{
${ }^{34}$ Boloña, 99-100.

${ }^{35}$ Boloña, 100.

${ }^{36}$ Torres y Torres Lara, 81. Ironically, these were the grounds that Congress used in 2000 to refuse Fujimori's resignation and impeach him.

${ }^{37}$ Torres y Torres Lara, 82. San Roman was declared President after the autogolpe by Congress, but without either popular support, or the support of the Armed Forces, he quickly faded from the political scene.
} 
million. ${ }^{38}$ The cost of this program threatened the viability of the entire economic program by incurring a major deficit, and more importantly, according to Boloña, by undermining the logic of the program in offering privileges to one sector. ${ }^{39}$ The real threat to reform, according to Fujimori, was from illegitimate and corrupt actors who sought to perpetuate a corrupt system that had bankrupted Peru.

After the autogolpe, power became even more centralized and dependent on the executive. One of the chief targets of the autogolpe was the judiciary, who had been vilified by Fujimori as jackals responsible for freeing terrorists and drug traffickers. Less than $10 \%$ of all those charged with terrorist offenses were convicted since Senderistas were able to get off through intimidation and corruption. ${ }^{40}$ But the purge of the judiciary was not simply a matter of replacing corrupt judges with untarnished and independent judges - for $85 \%$ of the new appointments to the judiciary were only appointed provisionally. ${ }^{41}$ Provisional judges could be dismissed at will for ruling against the government and thus the judiciary became subject to the whim of the president.

After the autogolpe, the victory of Cambio 90/Nueva Mayoria in the Constituent Assembly elections of November 1992, effectively hamstrung Congress as a counter weight to the Presidency. With the President's supporters

Boloña, Cambio de Rumbo, 95-96.

39

Boloña, Cambio de Rumbo, 96.

${ }^{40}$ McClintock, 60.

${ }^{41}$ Conaghan, 312. 
in control of Congress, charges of corruption against Fujimori and the military along with accusations of human rights violations by the military were simply not investigated. ${ }^{42}$ The opposition was not consulted as to the agenda for Congress, which meant that it could not raise issues or conduct research ahead of time on problems with proposed legislation. ${ }^{43}$ Controversial legislation was simply rammed through in infamous midnight sessions. ${ }^{44}$ Key economic measures were also passed in all night sessions, resulting in what Carol Wise called "an eerily apolitical atmosphere", where controversial economic policies received little or no public debate. ${ }^{45}$ This meant that the opposition could not perform its democratic function as a loyal opposition and the legislature could not perform its democratic function of deliberation. Without the ability to hold the executive to account through Congressional investigations, or publicize and effectively criticize legislation, Peru's Congress had become irrelevant.

In conclusion, Fujimori's reorganization of the Peruvian state effectively imposed an authoritarian order behind a democratic facade. There were no checks left on his power. His Cabinet was composed of political naiffs, independents and technocrats who merely rubber-stamped his decisions, with

\footnotetext{
${ }^{42}$ Conaghan, 312

${ }^{43}$ Planas, 195-196.

${ }^{44}$ Conaghan, 306. The most notorious midnight session was the amnesty for all police and military personnel charged with human rights violations, passed in 1997.

${ }^{45}$ Carol Wise, "State Policy and Social Conflict," in The Peruvian Labyrinth (University Park, Pennsylvania: University of Pennsylvania, 1997), 84.
} 
the President "always having the last word."46 His "movements" were merely collections of candidates for congress and never developed a mass membership, consultative structures or a permanent organization. Thus, Fujimori's political movements were never allowed to develop into a political party. The civil service was also not independent and hence could offer no institutional resistance to Fujimori's plans. The independence of the judiciary was fatally compromised first by the purge after the autogolpe and then by Fujimori's refusal to make new appointments permanent. The legislature was neutralized by its pro-Fujimori majority. Government Congressmen and Congresswomen usually had no political experience or profile prior to election, and hence owed their political existence to Fujimori. Time and time again they supinely parroted the government line. ${ }^{47}$ Government stonewalling prevented Congress from investigating government scandals. The total result of this reorganization was the emasculation of all constitutional checks and balances on the Presidency, and the concentration of all power into the hands of Fujimori.

\footnotetext{
${ }^{46}$ Quote from Juan Carlos Hurtado Miller in Pilar Davila Perez, "La vision de las Implementadores de Politicas" en Implementacion de Politicas Publicas en El Peru, 173. Hurtado Miller was the first Minister of the Economy and Prime Minister under Fujimori, and was commenting on the formation of the first economic plan. It is interesting to note that even in a technical debate between economists, Fujimori reserved the ultimate decisions for himself.

${ }^{47}$ The examples of the Cambio 90/ Nueva Mayoría Congressional majority blindly following the government's lead to the point of obsequiousness are legion. Just one example, was the prevention of a referendum on the eligibility of Fujimori for a third term during 1997 to 1998 . First 1.4 million signatures were collected to call for the referendum as required under the new constitution. Then Congress first passed a requirement for a super majority in Congress to approve any referendum, and of course no referendum was ever called.
} 


\section{Fujimori and NeoLiberalism:}

\section{The affinities between an Autocrat and an Ideology}

While the construction of a new authoritarian political system suited Fujimori's preferences, it also reflected the needs of a transformation to a neoliberal order. At the core of the affinity between Fujimori and neoliberalism was a shared vision of the source of Peru's catastrophe. Fujimori believed and neoliberal theory argued that the old style of accommodation had led to corruption and had destroyed the economy. Previously, democratic political ideals valued accommodation and democratic negotiation for the inclusion of subordinate groups in society as a means of securing social peace. But Fujimori and his neoliberal ministers blamed this accommodation as the source of social corruption which had led to a moral, political and economic collapse.

Neoliberal thought provided the moral justification for the destruction of the old order and the construction of a new economic and political order. In addition, a stable, disciplined government that was autonomous from pressure from social groups was required for a lengthy period of time for the neoliberal economic cure to transform everything as well as show positive results. Thus neoliberal restructuring condemned the previous order while it justified a spell of authoritarian government.

While Fujimori implemented neoliberal reforms, he was not a neoliberal when first elected. He was elected on a nebulous anti-shock platform, that had 
more to do with positioning himself to the left of Vargas Llosa in the runoff election in 1990 (see Chapter One). He was converted by international pressure to the necessity of neoliberal shock policies within weeks of being elected (see Chapter 4 for a fuller description of the role that international pressure played). Once in office, he implemented the harshest shock policy in Latin American history, with little compensation for those most affected by the shock.

What lay at the root of this affinity was a shared perspective. Fujimori's critique of the root causes of the problems of Peru closely parallelled the ideological mindset of his neoliberal technocrats. Where Fujimori railed against the corruption of the old party system, Milton Friedman had already argued that problems in the United States and Britain were caused by an "iron triangle", a corrupt alliance made up of three monopoly-seeking groups- the beneficiaries of government programs, bureaucrats and politicians. ${ }^{48}$ Carlos Boloña, Fujimori's finance minister, described the cause of Peru's problems as what ... "Milton and Rose Friedman had described as the "triangle of iron" that protected their privileges and rights that had acquired and prevented the dismantling of the redistributive mechanisms of the state." ${ }^{39} \mathrm{He}$ argued that the first part of the triangle was the tyranny of the beneficiaries or the civil society organisations or

See Milton Friedman, Tyranny of the Status Quo (San Diego: Harcourt Brace Jovanovich Publishers, 1984), 166.

Boloña, 90. Translated by author. 
gremios, which included unions, business associations and professionals. ${ }^{50}$ The second tyranny of the triangle was that of the bureaucrats, especially their unions and associations. The third pole of tyranny in the triangle were the politicians, whose campaigns were financed by the beneficiaries. ${ }^{51}$ Each of the parts of the "iron triangle" used their position to extract rents from the rest of society through higher wages, protected monopolies in the marketplace, or by extracting subsidies from the state. Each pole was entrenched and protected by their relationship to each other. But what is interesting to note about Boloña's argument, is that the source of this idea was Milton Friedman, and hence this analysis explicitly connected Peruvian political discourse to the broader ideology of neoliberalism.

What neoliberalism offered Fujimori was a broader ideological vision that supported his own distaste for the corruption of the old political elite. To both points of view, the old style of politics that was based on accommodating different interests by distributing rewards, either personally based on clientelism, or more broadly through redistribution to groups, was simply a recipe for corruption and disaster.

The privileging of the market left neoliberals vulnerable to supporting authoritarian regimes. Because the market was the highest good to neoliberals, it

\footnotetext{
${ }^{50}$ Boloña, 90. Gremios is a Spanish term for organizations that is difficult to translate into English. Gremios are peak level bargaining organizations that can range from business lobby groups, to unions, to professional associations, to small business organizations.

${ }^{51}$ Boloña, 90.
} 
took priority over the democratic priority of building consensus. An early critic of Hayek described the problem: "The only system of government that will give Hayek what he wants - namely, the protection of economic individualism in the extreme form that he wants it - is dictatorship which coerces whole peoples, and sneers at rule by persuasion." ${ }^{\text {52 }}$ Hayek avoided the problem of how to achieve popular consent to an economic system that benefited the few while beggaring the many, by simply describing all other systems as dictatorships and hence discarding them. As Herman Finer pointed out "if any democracy does not do what Hayek required in the name of economic individualism, it is a dictatorship." ${ }^{53}$ In fact, when Milton Friedman visited Chile he endorsed Pinochet and especially his former students' model of economic freedom within an authoritarian political order ${ }^{54}$ In practice, what was elected in the neoliberal conception of liberty was economic liberty. What was dropped was political liberty.

Yet there were additional practical political benefits for Fujimori adopting neoliberal reforms. By fulfilling the demands of the IMF and World Bank adherents and preachers of neoliberal thought, Fujimori was able to disrupt the ties between the state, political parties and broader society. The linkages between the party aristocracy and their supporters were broken, as sources of patronage were eliminated. Torres y Torres Lara described Fujimori's reforms as

\footnotetext{
${ }^{52}$ Herman Finer, Road to Reaction (Chicago: Quadrangle Books, 1963), 115.

${ }^{53}$ Finer, 37.

${ }^{54}$ Elton Rayack, Not so Free to Choose: The Political Economy of Milton Friedman and Ronald Reagan (New York: Praegar, 1987), 37.
} 
cutting the Gordian knots of power, as ending the corrupt clientelist system of compradazgo (or godfatherhood) ..$^{55}$ This system had distorted the laws of Peru, as special exemptions were made for friends regulation by regulation, law by law, until Peru strangled in red tape. But cutting the old system of personal connections also involved permanently cutting the linkages between the political elite and their power base, undermining the opposition to change and creating a political vacuum filled by Fujimori.

However, as argued in Chapter One, the linkages between the political elite and society based on redistribution had already been disarticulated by a crisis of representation and a collapse in the state's capabilities. What the ideological attack on compradazgo accomplished was the prevention of a regeneration of political parties based on the previous political culture. Politicians would have had little to offer groups if redistribution through the state was effectively banned from this political practise.

But the need to conduct a moral revolution in Peruvians' expectations of the state legitimated a lengthy stay in power for Fujimori. Boloña argued that based on the cases of Bolivia and Chile, it would take seven to ten years of political and programmatic stability to break the iron triangle. The World Bank argued that it took ten years before the benefits of structural adjustment would be felt. ${ }^{56}$ Victor Joy Way, the Fujimorista head of Congress, declared that Peru needed twenty to thirty years of Fujimori and his party to complete and enshrine

\footnotetext{
${ }^{55}$ Torres y Torres Lara, 33-40.

${ }^{56}$ Boloña, 131-134.
} 
his reforms. ${ }^{57}$ Thus the neoliberal reform project legitimated Fujimori's continued rule, even though, after the Mexican Revolution, the norm in Latin America was that presidents be limited to one term in office.

One of the foundations of Fujimori's alliance with the military was a long term civilian military dictatorship justified by the need to impose neoliberal economic reforms. The officer corp had shifted to the right since the left wing reformist military government of Velasco. They had lost faith in the economic plans of Velasquismo, partially because of the leftist challenge posed by Sendero. ${ }^{58}$ They had also given up on state-led industrialization because of the decline to their own income caused by inflation under Belaúnde: a general was only paid $\$ 550$ a month. ${ }^{59}$ Elements in the officer corp supported the imposition of neoliberal policies because of its success in Chile, and because of a desire to impose economic order. Prior to the 1990 election, the military had a secret plan to solve Peru's problems code named Plan Verde. The plan called for " the construction of a "Directed Democracy and a free market" until the millennium. A civilian and military government would assume responsibility for directing the

${ }^{57}$ Carlos Ramos, "Plan de Gobeirno de 20 a 30 años revela Joy Way", El Sol 9 July 1997, 1. The call by Joy Way for thirty years of Fujimori was controversial because, at the time, Fujimori's drive for a third term in office had caused the purging of the Constitutional Tribunal and mass protests. This call for an indefinite period in office was a trial balloon that signaled Fujimori's determination to seek more terms in office, even after his third. Economy, ed. John Crabtree and Jim Thomas (London: Institute of Latin American Studies, 1998), 198.

Obando, 195. 
destiny of the nation." ${ }^{n 0}$ The dictatorship the Green Plan called for would implement neoliberal market reforms and last at least ten years. ${ }^{61}$ Fujimori first denounced the Plan, but by having the authors of the Plan accompany him during the inauguration of the head of the army, he indicated his support. ${ }^{62}$ What was important about the neoliberal economic reforms and the autogolpe was not just that they fulfilled pre-existing military plans, but rather that they allowed Fujimori to pre-empt a coup by reassuring the military that Fujimori had a plan to solve Peru's crises.

Neoliberalism provided the ideological glue that held together Fujimori's coalition of the military and technocrats: Fujimori's overall project for a "liberal economy within an authoritarian order" Thus, neoliberalism provided the project for the future that legitimated Fujimori's authoritarian regime as a necessary stage on the road to Peru's recovery.

\section{Fujimori and the Technocrats: Affinities to Fujimori's Political Interests}

Beyond providing the rationale for an authoritarian coalition, neoliberalism as a project also brought with it a group of experts capable of running the

\footnotetext{
${ }^{60}$ Quoted from the document by Alberto Adrianzen M., "El "Plan Verde"', Que Hacer 107 (May-June 1997), 7. Plan Verde translates as the Green Plan. Translated by author. Directed or guided democracy was Pinochet's term for his restrictive version of democracy. According to Pinochet, the military reserve decisions in large areas of government policy for itself while enshrining in the constitution its circumscribed vision of the subjects open to democratic debate.

${ }^{61}$ Obando, 197.

${ }^{62}$ Adrianzen M., 7. This kind of symbolic communication was a typical political maneuver during the Byzantine Fujimori era.
} 
government. Underlying the alliance between the neoliberal technocrats and Fujimori was a set of practical political advantages. The technocrats as a group offered Fujimori the advantage of expertise combined with a lack of independent political stature that meant they were completely dependent on Fujimori for their positions. But what they did offer were the connections and credibility with the international financial institutions which were crucial to the reinsertion of Peru into the global economy.

One of the roots of the political appeal of the technocrats for Fujimori, was their claim to technical expertise. Contained within his first campaign slogan "honesty, technology and work" was an appeal to science as a way to avoid the divisiveness and conflict of other Peruvian politicians. The Left's discourse was based on clasismo or appeals based on invoking class resentments, while the right attacked the status quo for its regulations that infringed on their liberty. However, both discourses were based on conflict, and conflict had an ominous ring in the times of Sendero.

Technology, in contrast, offered "scientific" solutions to people's problems without creating class conflict. Since technological solutions to problems are apolitical, they are based, in theory, on the scientifically best solution and hence do not involve choice. Technically correct solutions were to revolutionize and develop Peru without creating political conflict. But to find and implement the best solution required technocrats, those who are proficient in the latest scientific methods and policies. Thus technocrats granted Fujimori's government a patina 
of scientific detachment and competence, far different from the divisive disaster of Alan Garcia.

However, one of the ironies of the Peruvian situation was that while the public image of the technocrats was that they dispassionately, logically made their decisions on the basis of politically neutral scientific principles, the technocrats themselves had no such illusions. The unanimous opinion of all the technocrats interviewed when asked, was that economics was not a science that dictated only one possible answer. ${ }^{63}$ They were all well aware of the political nature of their policy choices.

Yet technocrats offered Fujimori a politically "neutral" cadre of experts. Indeed, the technocrats chosen by Fujimori were selected for their political inexperience. One of the questions asked of a candidate for a senior position within the administration was: "Had they ever been previously politically active?"64 Political inexperience was a requirement because those who had been active were contaminated by the culture of corruption of the partidocracia.

But those who had no political affiliation also lacked political connections. A lack of political experience meant that technocrats as individuals represented no groups in society; nor did they offer their own personal political organizations. Also, a lack of political connections to civil society helped when reorganizing

\footnotetext{
${ }^{63}$ This was the unanimous opinion of all subjects of interviews conducted during 1997. Interview subjects ranged from former cabinet ministers, to presidential candidates, to deputy ministers, to those involved in program areas.

${ }^{64}$ Interview with a former official, July, 1997.
} 
social relations of production. Technocrats lacked social connections to those harmed by their reforms so they owed no political debt to the rentiers of the state. This lack of political connections was also one of the differences between Peruvian technocrats and those from other countries in the region. In the Mexican case, technocrats rose to power within the corporatist system of PRI, and relied on personal friendship and family networks called camarillas who rose together as a group within the bureaucracy and the party until taking over the presidency. ${ }^{65}$ Peruvian technocrats were also not formed from a like-minded network of graduates from the same graduate program like the Chicago Boys in Chile. Under Fujimori, in the small world of Peruvian technocracy they all knew each other but would move in and out of office as individuals. The career path for economists was to serve a short term in government, and then use that experience to market themselves as consultants to international organisations like the World Bank and IMF. In a survey of economists conducted in 1992, 87 percent had consulted for these international organisations. ${ }^{66}$ While Peruvian think tanks provided work for technocrats when out of office, they were not the basis for claims to power from either connections or expertise. For example, the most internationally well known Peruvian economist, Hernando De Soto who had

Ben Ross Schneider, "The Material Base of Technocracy: Investor Confidence and Neoliberalism in Latin America," in The Politics of Expertise in Latin America, ed. Miguel A. Centeno and Patricio Silva (New York: St. Martin's Press, 1998), 81.

Catherine M. Conaghan, "The Ascent of Economists in Peru," in The Politics of Expertise in Latin America, ed. Miguel A. Centeno and Patricio Silva (New York: St. Martin's Press, 1998), 154. 
written on how state regulations crippled development. His institute Instituto Libertad $y$ Democracia focussed on the need to regularize property titles in the pueblos jovenes. There were members of his institute that helped to found Vargas Illosa's political party Libertad, but they were shut out of power when Fujimori was elected. Yet despite (or because of ) his prominence, De Sotto only briefly consulted on drug policy before being also shut out of power. ${ }^{67}$ So while technocrats in Peru did form a group, they did not constitute a power base.

But while their political isolation made them useful, it also made them vulnerable and easily replaceable by Fujimori. This meant that no technocrat, no matter how prominent or capable, could build a political profile or power base independent of the President. Fujimori did not rely on personal alliances with technocrats and instead, used them, compromised them, and then disposed of them. ${ }^{68}$

The only set of connections that the technocrats offered Fujimori were linkages to the international financial community. These relationships were based on a shared set of values, experiences and education with the staff of the IMF. They were politically crucial for the successful reinsertion of Peru into the international financial system. Fujimori needed their credibility to conclude

Conaghan, 155-156.

${ }^{68}$ Boloña, who was the chief architect of the neoliberal reforms, lasted only 22 months under Fujimori. He was resurrected as Fujimori's economic minister at the end of Fujimori's second term. 
successfully negotiations with the IMF and World Bank for a structural adjustment program.

Thus, the technocrats performed a contradictory role in Fujimori's Peru.

On the one hand, they led and staffed the ministries and designed and implemented the reform program. But on the other hand, they were apolitical and had no connection to the political world of parties and civil society. The technocrats possessed no independent political resources beyond their appointment by Fujimori. Thus, like the courtiers of the Sun King, when they had the monarch's favour, they had power and influence. But when they went into eclipse by losing the favour of Fujimori, they politically disappeared.

\section{Technocrats and their Affinity to Fujimori}

While it was in Fujimori's political and ideological interest to ally with neoliberal technocrats, why was it in their interest to work for a dictatorship? This question reveals more about northern biases than the reality of Peru. In fact, working for the government was the only source of employment beyond badly paid teaching jobs. While many of the technocrats interviewed had positions teaching at Peruvian universities and positions in Peruvian think tanks, the only way technocrats could apply their knowledge was to accept political appointments. For many, considering the desperate shape of Peru, inaction in the name of moral purity was not a responsible or a reasonable response.

Yet at the core of the affinity between neoliberal technocrats and an authoritarian regime was a mission to destroy the old corrupt system. From this 
viewpoint, to save Peru from bankruptcy, required a heroic cadre of disciplined technocrats who would use the authority of a Caesarist dictator to dismantle the old systems of privilege, connections and corruption. Protests from civil society were dismissed as "the whining of special interests losing their rents." If no public pressure was regarded as legitimate, then the only authority that was left was that of the dictator.

The background of neoliberal technocrats also left them vulnerable to cooptation by Fujimori. As a group, the technocrats that were interviewed were curiously detached from a social base within Peru, they were declassed and denationalized ${ }^{69}$ They unanimously politely ignored questions about family background, while happily describing the elite northern universities where they had pursued post-graduate studies. Thus, while they did not identify with ethnic or class backgrounds, they did identify with their status as an educated elite. However, unlike the "Chicago Boys" under Pinochet ${ }^{70}$, they did not all attend the

Based on interviews conducted in 1997, with a broad cross section of current, former and future officials in Fujimori's government. The subjects ranged from candidates for the Throne of Pizzarro (the Presidency) to cabinet ministers, to deputy ministers, to heads of programs, to officials within the ministries. One interesting thing of note was that the subjects were from a broad mixture of ethnicities, from white, to cholo, to Japanese, to indio, a more heterogeneous mix than was usual in Peru. While race does not determine economic position, it is usually considered an indicator of it in Peru. The interviews were conducted in July and August of 1997.

${ }^{70}$ The best source on the Chicago Boys is Juan Gabriel Valdes, Pinochet's Economists: The Chicago School in Chile (Cambridge: Cambridge University Press, 1995). Valdes described how the Chicago Boys were recruited at the Universidad de Catholica in Santiago, to study under Harberger and Friedman at the University of Chicago. This group then implemented the first neoliberal revolution under Pinochet. 
same school in the United States based on one scholarship program. ${ }^{71}$ Nor were they indoctrinated into the values of neoliberalism by their studies. In one case, the "King of the technocrats", Carlos Boloña, studied under a Marxist economic historian, Rosemary Thorp, at Oxford. Boloña himself argued that he had not learned his neoliberalism at Oxford but instead the situation of Peru had converted him to the Austrian school. ${ }^{72}$ The experience of the failure of García and not indoctrination had converted economists to neoliberalism.

Instead of bonds of personal loyalty, the attraction of the technocrats to Fujimori's regime was twofold: power and the glory of the mission. When asked why he chose to work within the government of Fujimori rather than remain outside as a consultant or work overseas, one official said that it was better "to be the head of a rat than the tail of a lion. ${ }^{73}$ Better to work at the centre of power in Peru, than toil at a lesser rank in a more powerful institution like the IMF. Fujimori offered power to academics who lacked the connections and prominence that had been a prerequisite for power, while his personal story

\footnotetext{
${ }^{71}$ They attended universities from Stanford to Texas, to Chicago, to Cambridge, to Oxford.

${ }^{72}$ Interview with Boloña. The Austrian School refers to followers of Hayek and Ludwig van der Mies, the less simplistic predecessors of the Chicago school. However, while Boloña claimed to not be a follower of the Chicago school (the Chicago Boys were a bit of an ethical embarrassment), he did quote extensively from Friedman in his own book. He was also a close collaborator with Hernan Buchi, Pinochet's last economist, and Pinochet's replacement for the pro-regime ticket in the Chilean election of 1990.
}

${ }^{73}$ Interview with subject August, 1997. 
offered the hope that one day they too could sit on the Throne of Pizzaro. ${ }^{74}$

Neoliberal technocrats also needed Fujimori as the head of their project, for Libertad, their political formation, had failed. ${ }^{75}$ Fujimori's presidential authority enabled them to institute their reforms while his popularity generated the required political support and legitimacy.

The loyalty of the technocrats to Fujimori came from their loyalty to the mission and not from any pre-existing personal connection or any charismatic charm of Fujimori. Fujimori had been the rector of the Agrarian University, and a mathematics teacher. He was a cold and austere figure, who used vector diagrams to plot out his next political move. ${ }^{76} \mathrm{He}$ was by no means a spellbinding orator. Martin Tanaka, a Peruvian sociologist, painted this portrait of Alberto Fujimori during his last campaign in March 2000:

Of course for Fujimori, there is the hallucination of the crusade for his country that is his duty: boldly risking all to save the country from terrorism and hyperinflation, and to reconstruct it. He works only for his country obsessively every day; he has completely sacrificed his family and his personal life, his life is stoical and Spartan; he has no personal life, vices,

\footnotetext{
${ }^{74}$ Many of the technocrats and academics that were interviewed expected to run for the presidency, despite their complete political inexperience and connections to political parties. Two of those interviewed were in fact candidates in the elections of 2001; one was victorious.

${ }^{75}$ Libertad was the new political party of Vargas Llosa, and was staffed by the young followers of Hayek and Friedman and their writings, and the work of Hernando de Soto, and who popularized neoliberal theory in Peru. Mario Vargas Llosa, A Fish in the Water (New York: Penguin Books, 1994), 171. Because of their connection to Peru's failed elites, this group lost the election of 1990 (see Chapter One), and disappeared as a political formation after the autogolpe.

${ }^{76}$ Interview with former colleague, Lima, July 1997.
} 
passions or friends; his only passion is the exercise of power. I see a person who is totally empty inside, someone who inspires only sadness. ${ }^{77}$

Fujimori had no cúpula, or circle of friends, amongst the technocrats who formed his team.

Hence, beyond the lure of personal power, the reform project was the primary motivation behind loyalty to Fujimori. For example, Carlos Boloña, when he was surprised by the autogolpe, decided not to resign at some personal risk because of the importance of seeing the reforms through. ${ }^{78}$ Boloña justified his continuation in office on the grounds that "the change in direction" after forty years of mercantilism, had not taken hold, and that to prevent a return to interventionist economic policies, he had to stay in office. ${ }^{79}$ Economic reforms took precedence over constitutional norms, with the hope that once the reforms had taken hold, a major liberalization of politics and a real democracy could take place in the future. ${ }^{80}$ Neoliberal economic order trumped democratic consent, the free market was the hallmark of value, not democracy. An authoritarian political structure, while it may be uncomfortable, at least allowed neoliberal technocrats

\footnotetext{
${ }^{77}$ Martin Tanaka, "El baile del chino," Domingo, La República, May 28, 2000, 1-2. ${ }^{78}$ The constitution of 1979 declared that those who supported a coup, would be subject to the confiscation of all property, which was of concern to Boloña at the time. Interview with Boloña.

${ }^{79}$ Boloña, 99-100.

${ }^{80}$ Boloña, 99. Fujimori also expressed his desire for a "real" democracy once the parties and the courts had been reformed, in his televised address to the nation on April $5^{\text {th }}, 1992$.
} 
to impose their harsh economic medicine without being hampered by any need to build consent to change through consultation.

\section{Technocrats Attitudes towards the Union Movement}

An example of how the technocrats' attitude towards public consultation could have a profound impact on how reform was implemented can be found in their opinions about unions. Their contempt for unions meant that they did not have to seek their consent when labour market reforms were implemented.

Not only did the technocrats as a group lack experience within parties, they also lacked personal cross-class connections to leaders within the labour movement, and hence lacked any personal, as opposed to theoretical, knowledge of the necessity of union representation. In the unanimous opinion of a series of technocrats interviewed about the roles of labour unions, the common view seemed to be that labour should play no political role and that unions were without any useful expertise. ${ }^{81}$ Opinion was also unanimous that unions had no role to play in setting general government policy. To these technocrats, the labour code was not supposed to be the outcome of a class compromise negotiated between labour and business mediated by the state. Instead the labour code should be created as a rational project, by technical experts temporarily working within the state. However, all agreed that workers should

Interviews by author. 
have the freedom to form unions. Therefore, while technocrats interviewed did not express any overt hostility to the labour movement, they also did not view unions as a relevant interlocutor in the process of restructuring class relations and the economy. Consent was neither sought nor required. The labour code was a technical matter best left to economists.

An even more negative opinion of labour unions was expressed by Carlos Boloña. During an interview, he expressed the view that while he wouldn't expressly ban unions or prevent them from negotiating on behalf of workers, the best situation for workers would be to "negotiate directly with management as individuals, that would lead to the fairest and best contract for them." ${ }^{82}$ However, Boloña's antipathy to collective bargaining was only expressed in terms of preference or ideals, rather than principle. He was not proposing that unions be banned, just that they were not necessary. This statement was made in the context of an unemployment and underemployment rate of over $80 \%{ }^{83}$ But how could anyone expect to bargain for a fair contract in a situation where massive unemployment meant that there was ferocious competition for any job? The assumptions that were contained within Boloña's statement were based on a denial and a suppression of the history of the labour movement, that fair wages

Interview with author, August 1997.

Interview with a Peruvian labour ministry official. This official argued that the figure was so high, that it had lost its meaning and utility. However, even a corrected measure of unemployment and underemployment would have indicated that $55 \%$ of the Peruvian labour force was underemployed. 
would be paid voluntarily without unions (see Chapter Six for a brief history of Peru's labour unions).

Yet Boloña's attitude was not idiosyncratic; as we have seen in Chapter

Two, it reflected the underlying assumptions of neoliberalism as an ideology. His arguments against the labour movement repeated Hayek and Friedman's arguments. Boloña accused unions of being part of the "iron triangle" of beneficiaries. $^{84}$

Boloña's comments also reflected Hayek's assertions that unions were inherently monopolistic and violent.

Trade unions, often monopolistic, often fail to represent the interests of their members but rather benefit at their members' expense. For instance, when a union successfully negotiates a salary increase which surpasses the market rate, this improvement is made at the expense of non-affiliated workers. Unions also often limit the availability of workers and use violent coercive methods against both employees and employers. Certain unions, moreover obtain protection from the government through pressure or negotiation. This protection is effected by means of legislation regulating minimum salaries, maximum working hours, wage scales, and work by minors. ${ }^{85}$

This statement contains certain assertions, contradictions and silences that justified the elimination of an effective labour movement. By using terms like "violent coercive methods," Boloña tied unions in general to the chaos and fear created by Sendero. Unions, according to this view, did not defend their

Boloña, "The Viability of Alberto Fujimori's Economic Strategy," 212. 
members; they oppressed them. Thus, Boloña inverted the moral order and blamed unions for the problems of the working class.

But the final part of the paragraph contained the most frightening subtext of all, that social rights were simply the result of union extortion to protect union members. This statement redefined all political victories by the labour movement not as a legitimate result of social struggles throughout the twentieth century but as the products of political blackmail. General rights had become, by neoliberal alchemy, only protections for the privileged few.

However, the size and scope of the informal market, it could be argued, did create competition that undermined the general nature of social rights which therefore became privileges for the few. A different Peruvian technocrat in an interview did articulate this argument when he suggested that raising the minimum wage, while good politics, was irrelevant. If the minimum wage was raised, the increased costs would simply drive more businesses into the informal sector. Thus, while in theory the minimum wage mattered; in practise, competition from the informal sector undermined the capability of the state to regulate capital and enforce social rights.

In a situation where technocrats had been handed a blank cheque to redesign the economy which included the labour code, their attitudes towards the legitimacy of the labour movement was crucial. The neoliberal mindset and ideology justified the dismantling of Peru's labour movements, without consultation or consent. 
Thus frightening parallels existed between the mindset of a Caesarist dictator and neoliberal technocrats. In the case of the dictator, the corruption of the previous political order justified his imposition of a new political arrangement through a coup d'etat. The new political order then allowed Fujimori to rule unchecked. In the case of the technocrats, the unfettered nature of Fujimori's power allowed them to impose neoliberal economic reforms. Since labour unions were the product of a corrupt system, their consent was not necessary for the imposition of labour market reforms. The purging of political parties and labour unions was justified under the general rubric of purging the sources of corruption that threatened to destroy the nation.

\section{Conclusions: Neoliberal Revolution and Authoritarian Order}

Underlying the neoliberal revolution in Peru, were a crucial set of affinities between ideology and political institutions that reinforced each other. The neoliberal ideology that dismissed protests and political opposition as only the resentment of special interests legitimated authoritarian political structures. The authoritarian political centralization of all power into the hands of the executive allowed neoliberal technocrats to impose "structural adjustments" to economic and political formations to construct a new neoliberal order. Thus neoliberal ideology legitimated an authoritarian regime, as a "lesser evil" ${ }^{86}$ than the continuation of the previous mode. Neoliberal technocrats and the authoritarian

\footnotetext{
${ }^{86}$ Boloña, Cambio de Rumbo, 100. Boloña said that it was a "lesser evil" to continue under Fujimori after the autogolpe, than to abandon his reforms, and to allow the return of Alan Garcia.
} 
Fujimori coexisted in a stable and mutually reinforcing alliance after the autogolpe, where the technocrats provided the program, and Fujimori, the power.

Yet the Caesarism of Fujimori was necessary to this political project. The previous structures of representation had failed. No class had the capability to impose the new mode in Peru. Those who had gained power under the old system the judges, the members of Congress, the government officials - seemed to be organizing to block reforms and preserve their power. The Bonapartist coup of April 5, 1992, was therefore a coup de main against the old order, so that the new order could be born.

Neoliberalism as an ideology provided the ideological glue that held together the alliance behind Fujimori's authoritarian project. Neoliberal notions about the iron triangle created a common excuse that justified the repression of dissenting voices from the old order. But the state formation the project created was an isolated, autonomous state with all power centred in the presidency so that the state could be insulated from pressures and demands from society. Thus neoliberalism as an ideology justified a technocratic autocracy, where experts could rule unfettered and undisturbed by the masses.

But why was the new order neoliberal? From this chapter it is clear that the new neoliberal order was internally coherent. But other ideological currents existed in 1990, with stronger ties to existing class fragments, from socialism to state capitalism. What the Peruvian case clearly demonstrated was the power of international forces to make that choice neoliberal. Their role is the subject of the next chapter. 


\section{Chapter Four: Hegemony and Enforcement:}

\section{The Role of International Financial Institutions in Peru during the Transition to a Neoliberal Order.}

The example the international financial institutions (IFIs) made of Peru revealed the particular methods through which the hegemony of a neoliberal world order was enforced. The IFIs used Peru to demonstrate that they would not tolerate debt strikes and that there was no non-suicidal alternative to following a neoliberal structural adjustment program.

However while this chapter addresses the role that the IFIs played in the choice of neoliberalism as the model for Peru's transformation, the process was still firmly located within the political conjuncture of Peru. This chapter integrates the influence of forces from outside Peru within an understanding of how transformations take place. While crises in the previous regime of accumulation may have forced nations on the periphery to undergo a transformation, this chapter answers questions about how international hegemonic forces pushed specific choices.

This chapter makes use of the terms of periphery and centre not to locate the work within a specific school of dependency theory, but simply to highlight the differing structural position of Peru versus the "developed" world. Each nation in the periphery experienced dependency differently according to its own history and the interplay of the forces of global capitalism with these nations' orders. Periphery and centre are useful heuristic constructs to highlight general 
tendencies. Along with the industrialized north and its governments and transnational corporations, the centre includes those international institutions like the IFIs that regulate the international system. Thus to observe that Peru's economy was reconstructed to emphasize the efficient production of primary goods for the benefit of the "centre" is a way of describing how Peru's reconstruction benefited industrial economies without ascribing either unity or planning to the centre's national governments. Instead of planning, it is more accurate to describe the actions of the IFIs as motivated by preferences, preferences set by a neoliberal political revolution led in the centre by US President Reagan and British Prime Minister Thatcher. Neoliberal beliefs then defined what policies these institutions would find acceptable. The process of how the IFIs structured Peru's choices is the subject of this chapter.

Because the imprimatur of the IMF was a precondition for Peruvian access to international capital markets and hence economic recovery, the IMF possessed a veto and de facto control over the general direction of Fujimori's economic policies. Within the Peruvian government, the need for IMF approval lent political strength to those technocrats able to garner the IMF's support, especially the finance minister Carlos Boloña. During this period, the support of the IMF was used to win domestic political struggles over applications of economic policy to specific areas.

The irony of these changes was that while they were supposedly designed to help Peru, in fact they restructured Peru for the centre's benefit. While a change in economic direction was necessary, there were other sensible options. 
Peru could have opted for the state-guided, export-oriented route of the East Asian model, where growth with equity and periodic regulated wage increases forced producers up the production cycle. ${ }^{1}$ While a full comparative description of this model lies beyond the scope of this thesis, following this path would have required using tariff rates, access to subsidized capital as well as forced technology transfers to aid Peru's industrial development. All of these measures were prohibited within the Washington Consensus on economic policy (see Chapter 5). Another direction that had success was the path chosen by Chile under Concertacion in 1990. The new civilian government in Chile negotiated a social pact between labour and business that balanced an increase in tax rates combined with an increase in state spending on human capital formation. Yet again, the neoliberal drive to reduce the scope of the state meant that Peru did not follow this other path. The elimination of the responsibility of the state for the economic direction of Peru guaranteed the property rights of international capital while ignoring any responsibility for local development or equity. Reinsertion into the international financial system was also predicated on the Peruvian state faithfully making interest and debt repayments to the IFIs and international creditors. Thus neoliberal structural adjustment transformed the Peruvian state into a tribute extractor for the centre.

This chapter will explore how the IFIs enforced their hegemony and

1

See Stephan Haggard, Pathways from the Periphery for a standard account of this model. 
ensured that there was no alternative to neoliberalism for Fujimori. First, this chapter will explore why Peru mattered to the IFIs as a rebel against adjustment and hence why the IFIs insisted that there was to be no alternative to structural adjustment for Peru. This section will show that structural adjustment was not accepted passively by Peruvians, but instead there were a series of successful social rebellions against the dictates of the IFIs. Because neoliberal hegemony had to be imposed, it was not economic fate, nor the result of the unfolding of reason nor the end of history with the convenient fatalism and capitalist triumphalism of neo-Hegelian writers like Francis Fukiyama. Secondly, the chapter will explain how pressure and political intervention by the IFIs led to Fujimori's conversion to neoliberalism which will help further develop our understanding of hegemony as process. Finally, this chapter will apply Gramsci's concept of a passive revolution and a cosmopolitan intellectual stratum to further explain the role and position technocrats played in the transformation of Peru.

Peru was important to the IFIs because it had to be reined in as a rebel against the New (neoliberal) World Order. Structural adjustment was crucial for Peru because only through reinsertion into the global financial system could Peru pull back from the brink of a total economic, political and social collapse. But the terms for re-acceptance by the IFIs involved more than improving economic efficiency; they adjusted the Peruvian order to fit into the new global order.

\section{Why Peru Mattered to the IFIs: Debt Strike and Discipline}


Prior to Fujimori, structural adjustment programs had simply sparked social rebellions. The pattern of these years was that the government would agree to implement economic reforms in return for IMF loans, only to back down when faced with social unrest and mass protests led by organised labour. Thus, before Fujimori, the labour movement had effectively vetoed the implementation of neoliberal reforms.

This history of rebellion against structural adjustment began under the military regime of President Morales Bermudez (1975-1980). When the Bermudez government was faced with a balance of payments crisis in 1976 due to high debt levels, the military regime turned at first to foreign private banks for more financing. ${ }^{2}$ The government preferred this source, since they would not exact the same rigid standards and demands for austerity as the IMF. The government was worried that cutbacks would lead to political unrest. ${ }^{3}$ However, the demands of the banks were still onerous: the government was forced to announce the elimination of food and gas subsidies, a $40 \%$ devaluation and cutbacks in government spending. ${ }^{4}$ The labour movement responded by calling a massive paro, the largest one day general strike since 1919. This led to widespread rioting and forced the military government to speed up Constituent

$$
2
$$

Teivo Teivanen, Enter Economism, Exit Politics: Experts, Economic Policy and the Damage to Democracy (London: Zed Books, 2002), 57.

${ }^{3}$ Teivanen, 57.

4

Peter Flindell Klaren, Peru: Society and Nationhood in the Andes (New York: Oxford University Press, 2000), 360. 
Assembly elections to draft a new constitution in preparation for a return to democracy by 1980 . When the crisis recurred in 1977 , the banks demurred and insisted that the government seek the assistance of the IMF. By May 1978, the IMF demanded an even stricter austerity program that would eliminate all subsidies and reduce the deficit. The unions responded with a two day paro followed by even more widespread rioting. ${ }^{5}$ The lesson for Peru's military leaders was that imposing IMF austerity programs led to social unrest and political suicide.

The newly elected, pro-business democratic government of President Fernando Belaúnde (1980-1985) also tried to implement some of the neoliberal reform agenda - specifically, privatization, tariff reductions and freeing government controlled prices. ${ }^{6}$ The development strategy of Belaúnde was based on a return to primary goods production as the engine of economic growth. Unfortunately, the prices of the primary goods that Peru exported collapsed to levels not seen since the 1930 's, ${ }^{7}$ causing a crisis in the balance of payments and then rising debt payments that forced Peru into default by $1984 .^{8}$

${ }^{5}$ Flindell Klaren, 362-363.

6

Carol Wise, "Democratization and Crisis in Peru", Debt and Democracy in Latin America, ed. Barbara Stallings and Robert Kaufman (Boulder: Westview Press, 1989), 168.

7

Deborah Poole and Gerardo Renique, Peru: Time of Fear (London: Latin American Bureau, 1992), 124.

8

Carol Wise, Reinventing the State: Economic Strategy and Institutional Change 
In addition, despite the predictions of the IFIs, the elimination of price controls and subsidies for basic consumer goods increased rather than decreased inflation. Price increases for these goods led to automatic wage increases to keep nominal incomes constant. But then, increasing inflation required more devaluation which in turn increased the prices of imported foodstuffs and gasoline, which reignited another inflationary round. ${ }^{9}$ During Belaúnde's term in government, inflation increased from $60.8 \%$ to $158.3 \%{ }^{10} \mathrm{At}$ the same time, a reduction of tariffs for textiles and automobiles increased imports and led to a loss of employment in these sectors. On every level, by every criterion, neoliberalism failed Peru under Belaúnde.

The increasing economic crisis was met with policy paralysis in the executive, a paralysis created in large part by political resistance to change. As Richard Webb, a member of Belaúnde's economic technocrat team, explained, the pressures preventing decisive action were formidable:

Surrounded by daily financial emergencies (road blocks by rice farmers waiting to get paid, banks going under, falling reserves, unpaid contractors threatening to stop work on key projects), and political emergencies (major strikes, military pressures, intense flak from lobbies, the media and Congressional opposition, including members of the government party), and in the context, furthermore of a newly recovered and still highly nervous democracy, major programmatic changes appear heroic. ${ }^{11}$

in Peru (Ann Arbour: University of Michigan Press, 2003), 82-83, 143-147.

${ }^{9}$ Wise, Reinventing the State, 142.

${ }^{10}$ Poole and Renique, 125.

${ }^{11}$ Wise, Reinventing the State, 146. 
At this time and in this context of economic crisis, political resistance to the neoliberal project by unions (via major strikes), lobbyists who represented the national bourgeoisie and Congress was sufficient to defeat its implementation. Then the economic failures of the neoliberal project led to a populist backlash and to the heterodox solutions of Alan Garcia and APRA.

As noted earlier, the government of Alan Garcia initiated one of the few explicit rebellions against paying debt to the IFIs, a rebellion that made Peru a financial pariah. Garcia's plan for the economy was based on a pledge to deal with the debt crisis by unilaterally limiting debt payments to $10 \%$ of foreign exchange earnings. ${ }^{12}$ The saved hard currency was then to be used for the reactivation of national industry. However García's refusal to negotiate with international creditors and the IFIs led first to a credit strike on further financing of international trade credits by private banks and then to suspension by the IFIs. The debt strike led to Peru's previous debts being downgraded on secondary markets from $50 \%$ to $17 \%$, an indication that Peru was expected to default. Hence despite García's promise to honour faithfully all new debts, no capital from foreign banks was available. ${ }^{13}$ As a first warning over the threat to limit debt payments, $\$ 900$ million in aid previously negotiated with the World Bank and Inter-American Development Bank was suspended upon García's inauguration. ${ }^{14}$

\footnotetext{
${ }^{12}$ Poole and Renique, 128-129.

${ }^{13}$ Wise, Reinventing the State, 163.

${ }^{14}$ Poole and Renique, 128.
} 
In 1986, Peru's failure to pay arrears to the IMF led to its suspension from IMF credits. In response to García's limits on loan repayments, the World Bank denied Peru any further loans. Then the IDB decided to refuse further loans until Garcíca came to an agreement with the World Bank. ${ }^{15}$ The IFls presented a united front to discipline Peru and ostracize it from the international financial system.

However, while ostracism hurt Peru, there was an additional strong motive for the IFIs to ensure that García's unilateral debt strike would fail. The spectre was that if other countries followed Peru's example, domestic banks in the US might fail and, with them, the entire international financial system. President García did try to organise a debt strike across Latin America and gave speeches against the IMF both at home and abroad, to the embarrassment of his hosts in Argentina. ${ }^{16}$ No other Latin American nation joined the strike. The IFls needed to respond to García's rhetoric forcefully to squash the rebellion. After García publicly ridiculed the IMF as a "paper tiger", a few days later at a meeting of the IMF board, the British executive director voted for new sanctions against Peru, precisely to prove they were not paper tigers. ${ }^{17}$ The need to maintain

\footnotetext{
${ }^{15}$ Teivanen, 72-78.

16

See Teivainen, $83-85$, for a description of Garcia's foreign crusade and the embarrassed hush of his hosts.

17

Teivainen, 74. Executive directors are appointed for a term to the board by their respective countries, rather than appointed from within the IMF. The directors then meet to approve Fund loans and set policies and sanctions.
} 
international financial control meant that Peru had to be made an example.

For the IFIs, the calamity of Peru under Alan García provided a useful example of what would happen to those who sinned against economic orthodoxy and who rebelled against the IMF. When Michel Camdessus the head of the IMF was asked what he thought of Garcia five months after the end of his term he said, "A very good example indeed of the bad things that happen if one does not comply with us."18 Without access to external capital, García's heterodox experiment failed catastrophically. Peru's pain proved that the IMF had the power to punish rebellion.

\section{The Role of the IFls in the Restructuring of Peru's Economy: Fujimori's Conversion on the Road to Washington}

While officially IFIs only advise their clients; in practise, power was exercised in order to force Fujimori to impose fundamental changes to Peru's economy and state. Together these changes transformed Peru and resulted in an entirely new set of economic social and political relations: a new order. Understanding how the IFIs intervened and interacted within the political situation of Peru answers questions about how hegemony is created and maintained by the centre over the periphery.

The IMF and World Bank forced the Peruvian government to implement the Washington Consensus in two major ways. First, these institutions

18 Teivanen, 107. 
disseminated neoliberal ideals through their connections with Peruvian technocrats. This educational role was not merely didactic or a discursively neutral exchange of ideas, since good relations with the IMF granted their favoured technocrats political weight and valuable consulting contracts. Secondly, the IFIs acted as the enforcers for the transition; without their imprimatur and endorsement, Peru was effectively cut off from the international financial system. Thus the IMF and World Bank created a situation in which there was no alternative to a structural adjustment program implemented by technocrats of whom they approved and whose policies they supported.

Fujimori's conversion on the road to Washington provides us with a clear example of how the IFIs directly applied power to force Peru to impose structural adjustment policies. During the election of 1990 , Alberto Fujimori was the antishock candidate, the candidate who promised not to impose a sharp increase to basic prices in the short run, and, in the longer run, not to impose neoliberal policies. However, Fujimori's anti-shock platform had less to do with his own preferences about economic policy than with the political situation in the second round run-off election against the explicitly neoliberal Mario Vargas Llosa.

During the first round of the election, Fujimori never articulated a clear economic program. He only brought in neo-Keynesian economic advisors for the run-off election. ${ }^{19}$ His platform was based on a direct connection to el pueblo, as we have seen, and a vague slogan that "honesty, technology and work" would

\footnotetext{
${ }^{19}$ Mario Vargas Llosa, A Fish out of Water (Penguin Books: London, 1990), 525.
} 
solve Peru's problems. During this election he did not even attack the corruption of the political elites and their parties. The effectiveness of his candidacy was based on being a symbolic outsider and not on an explicitly anti-system antiparty campaign. Without a clear stand on economic policy, Fujimori could change his policies to suit his political needs.

In the second round, Fujimori sought to attract those who had voted for candidates of the Left (IU and IS) and APRA. Support from these sectors was contingent on a rejection of Vargas Llosa's neoliberal policies ${ }^{20}$ Fujimori's base of support in the informal sector appealed to their own ideological class prejudices as defenders of the poor. APRA's campaign had focussed on fearmongering about Vargas Llosa's shock policies using images from the animated film Pink Floyd's The Wall. In these commercials, monsters ate people, and children disappeared into crevasses to depict the effect of Vargas Llosa's proposals to free prices, freeze salaries and cut the state's payroll. ${ }^{21}$ Thus the support of APRA and the IU/IS for Fujimori was based on the symbolism of his position as the anti-shock candidate against Vargas Llosa.

The tactical importance of this position was not lost on Fujimori. He understood that to get elected he had to cement the support of APRA and the IU. Since some adjustment was inevitable, one of his advisors suggested that

\footnotetext{
${ }^{20}$ Cameron, Democracy and Authoritarianism, 137.

21

Susan Stokes, "Democratic Accountability and Policy Change: Economic Policy in Fujimori's Peru." Comparative Politics (January 1997), 214.
} 
Fujimori should tone down his anti-shock rhetoric and be more of a statesman and less of a politician. Fujimori replied that "If I don't think like a politician now, I'll never get to be a statesman." 22

However, ten days after his inauguration, Fujimori imposed the Fujishock. This program was regarded as one of the most radical and harshest structural adjustment programs because it floated interest rates and cut tariffs and subsidies faster than elsewhere while having no provisions for emergency social aid. ${ }^{23}$ This was neoliberalism without mercy.

Fujimori converted to neoliberalism after his election because of pressure brought to bear during his pre-inaugural trip to New York and Tokyo. Hernando De Soto and UN Secretary General Javier Perez de Cuellar arranged for a meeting between the President -elect and Barber Conable, head of the World Bank, Michel Camdessus, head of the IMF and Enrique Iglesias, head of the IDB. Fujimori was given two options: institute a gradual heterodox adjustment like García and the IFIs would continue to block access to international credit or implement a structural adjustment program and eventually the IFls would help. In Japan, the Prime Minister told Fujimori that he had to reach an agreement with the IMF first before receiving new Japanese aid. In an interview, one of his neoKeynesian economic advisors Santiago Roca joked that the Emperor's first words were: "Nice to meet you, Mr. Fujimori. Reach an agreement with the

\footnotetext{
${ }^{22}$ Stokes, 218.

${ }^{23}$ Poole and Renique, 150-151.
} 
IMF."24 On the plane ride home, Fujimori mused aloud to his advisors, "If the shock were to work, the Peruvian people would forgive me.."25 He realized that, without the imprimatur of the IMF, Peru's economic crisis would continue.

The unanimous demand that Peru come to an agreement with the IMF predated Fujimori's election. On a tour of East Asia before the election, Mario Vargas Llosa had also been told in no uncertain terms that coming to terms with the IMF was a precondition for any resumption of aid or investment. When Vargas Llosa asked for investment in Peru's natural resource sector he was always told: "Yes, but before that (investment in Peruvian natural resources) Peru had to get out of its impasse with the International Monetary Fund, without whose endorsement, no country, bank or business enterprise would trust commitments made by the Peruvian government. ${ }^{\mathrm{n} 26}$

An agreement with the IMF was the only signal that international capital would accept that it was safe and worthwhile to invest in Peru again. An agreement with the IMF was the precondition for new investment by the Japanese government, the IFls, the Paris club group of creditors and foreign banks. This gave the IMF enormous power in its negotiations with Peru.

Unanimity meant that there was no alternative for Peru but to agree to the IMF's terms. The phrase there is no alternative, or the TINA principle, contains

\footnotetext{
${ }^{24}$ Stokes, 217.

${ }^{25}$ Chossudovsky, 200.

${ }^{26}$ Vargas Llosa, 262.
} 
within it one of the primary methods by which hegemony is maintained. If there are no alternatives to a specific set of policies like the Washington Consensus, then obedience becomes common sense, unchallenged and unchallengeable.

One of the ways that the IFIs held the upper hand over Peru was the delay caused by the need to clear Peru's arrears. Before Peru could receive any new loans or complete negotiations for the restructuring of its debt, the charters of these organisations dictated that all arrears had to be paid to them first. ${ }^{27}$ This requirement resulted in a situation whereby Peru first implemented structural adjustment on its own resources without receiving new loans to support poverty alleviation measures to cushion the poor against the shock of price increases and increased unemployment. The need to obey first in the hope of eventually receiving new loans weakened Peru's bargaining position vis a vis the IMF. ${ }^{28}$ The head of the IMF mission to Peru in 1991, Martin Hardy, expressed this power differential when he said, "Get a serious economic program and we will help you." ${ }^{29}$ The message was clear: demonstrate for three years that you will implement the Washington Consensus and only then we will allow you access to the international financial system. Because obedience over time was a precondition before the IMF would even enter negotiations, these negotiations were structured to their material advantage and not to Peru's.

\footnotetext{
${ }^{27}$ Boloña, "The Viability of Alberto Fujimori's Economic Strategy," 216.

${ }^{28}$ Chossudovsky, 202.

${ }^{29}$ Chossudovsky, 202.
} 
One of the primary methods by which the IFl's managed to ensure the adoption of the "right policies" was through the co-optation of Peruvian officials. These technocrats were brought into the system not through blatant bribery or official colonial appointments, but because their organic links were to the centre rather than to Peru.

\section{The Cosmopolitan Technocrats and the Passive Revolution}

How Peruvian technocrats came to be part of an international hegemonic caste is best understood through Gramsci's construct of a passive revolution. As Gramsci showed, when forces from the outside are allied with members of the intelligentsia to impose a revolution in the periphery, the direction this revolution takes reflects changes in the centre. This kind of revolution did not resolve the contradictions of the order of the periphery, but imposes solutions that reflect the conflicts and contradictions of the centre. Furthermore, Gramsci accurately depicted the centrality, yet political vulnerability, of this intelligentsia who, because they are ungrounded in structures of domination and production, were dependent on their foreign masters for their power.

According to Gramsci, a passive revolution was imposed on a nation from outside, a revolution that, while it changes the state, the social relations of production and its ethical political relations, was not based on the internal contradictions and social struggles of that nation. A passive revolution lacked the revolt from below and hence was in Gramsci's phrase, "a revolution without a 
revolution. ${ }^{\text {"30 }}$ There was no army of sans culottes storming the Bastille in Peru and driving the dissolution of the previous order and the imposition of a new neoliberal order that would reflect their aspirations and interests.

The moment that marked the passive revolution was the Caesarist coup of the autogolpe. This was a revolution launched without mass participation by a Caesarist leader who imposed his solutions from outside. Fujimori used the neoliberal blueprint to redraw Peru's order even though its ideas and ideals originated in the centre. The role of the Caesarist dictator in a passive revolution is to impose faithfully the new model of international hegemonic power, whether it is as Quisling or Adenauer.

The parallels between the political situation of Peru under Fujimori and Italy during the French revolution illuminated the roles of various agents. Instead of French armies, the IFl's supplied the force that enshrined the neoliberal order from the outside. Instead of "Jacobins and abstract rationalists, "enlightened" bourgeoisie $e^{31}$ and neoliberal technocrats staffed the neoliberal revolution. Like

30

Antonio Gramsci, Selections from the Prison Notebooks, ed. Quintin Hoare and Geoffrey Nowell Smith, (New York: International Publishers, 1971), 59. Gramsci adapted the term "passive revolution" from Vincenzo Cuoco, from whom he used this description of the Neopolitan Republic of 1799, "it was a passive revolution because it was the work of "enlightened bourgeoisie, abstract rationalists, "Jacobins," imitating French models (backed by French armies) with no mass participation."

31

This type of supporter of Fujimori was best personified by Jorge Camet who held various posts under Fujimori. While Camet was the former head of Confiep, the Peruvian business organisation, as an organisation Confiep had little influence over policy making, usually losing out to the IMF in conflicts over economic policy making. See Francisco Durand, "Collective action and the empowerment of 
the Jacobins and abstract rationalists in Italy who fell from power when the French withdrew, the technocrats had no organic linkages to a broad social base, and their rule could last only as long as the IFIs supported them.

The position of the technocrats was predicted within Gramsci's understanding of a passive revolution. Gramsci stated:

one can see how, when the impetus of progress is not tightly linked to a vast local economic development which is artificially limited and repressed, but is instead the reflection of international developments which transmit their ideological currents to the periphery - currents born on the basis of the productive development of the more advanced countries - then the group which is the bearer of the new ideas is not the economic group but the intellectual stratum. ${ }^{32}$

In the Peruvian case, the neoliberal reforms were imposed by a narrow technocratic intellectual elite who transmitted the new orthodoxy to the periphery and not by a national bourgeoisie who sparked a political revolution by changing the economy. As Robert Cox suggested, these technocrats operate as "an intellectual stratum which picks up ideas originating from a prior foreign and economic revolution." ${ }^{\text {33 }}$ In other words, Boloña implemented ideas he'd learned from the neoliberal revolutions of Thatcher, Reagan, and Pinochet not from a successful Peruvian revolution in the economy. The technocrats who

Peruvian Business" in Organised Business, Economic Change, Democracy in Latin America, ed. Francisco Durand and Eduardo Silva (Miami: North South Center Press, 1998), 271-272.

${ }^{32}$ Gramsci, 116-117.

33

Robert Cox, "Hegemony and International relations: An Essay in Method" Millenium 12, no. 2 (Summer 1983), 170. 
implemented the reforms were professors and economists from think tanks whose education brought them to prominence rather than family background or business experience. Hence the ideas and ideals of the technocrats reflected the neoliberal revolution in the centre.

Moreover, as Cox points out in his interpretation of Gramsci, the technocrats were .... "not an indigenous social group which is actively engaged in building a new economic base with new social relations of production. ${ }^{\text {“34 }}$ In Peru, technocrats implemented economic changes by changing the rules of the game and not by becoming entrepreneurs who reorganized production within the economy. The passive revolution was a change imposed by the state and not emergent bourgeois forces, and hence was a revolution from above.

The technocrats as a group lacked organic linkages to the bourgeoisie. When they were not in office, they tended to return to academic postings or think tanks, instead of the private business sector. For example, De Soto's ILD (Instituto Libertad y Democracia) received lavish funding from Northern sources, and hence did not reflect the interests of the Peruvian bourgeoisie. Even Confiep, the Peruvian business organisation, received $90 \%$ of its funding from USAID, at the level of 2 million dollars a year. ${ }^{35}$ Since the technocrats were independent of domestic capital, they were not organic intellectuals in the sense that the had been formed within domestic institutions to serve Peru's

\footnotetext{
${ }^{34} \mathrm{Cox}, 171$.

${ }^{35}$ Durand, 260.
} 
bourgeoisie. Instead, their organic links were to the centre.

But what did Gramsci mean by an "organic intellectual? Organic intellectuals were defined by the role they played within the order. The role of organic intellectuals linked to hegemony was to articulate ideas and ideals in the interest of the hegemonic class in its society. As Gramsci stated:

Every social group, coming into existence on the original terrain of an essential function in the world of economic production, creates together with itself, organically, one or more strata of intellectuals which give it homogeneity and an awareness of its own function not only in the economic but also in the social and political fields. The capitalist entrepreneur creates alongside himself the industrial technician, the specialist in political economy, the organisers of a new culture, of a new legal system, etc. ${ }^{36}$

Organic intellectuals perform the task of thinking through hegemony on an ideological level by expressing publicly the justification for policies, while on a practical level creating the policies that would institutionalize new social relations of production via the state. ${ }^{37}$ The difficulty with the neoliberal technocrats of Peru was that they were not organically linked to a dominant class of Peru. Instead they formed a new comprador elite linked back to international capital and an international hegemony based on neoliberalism as the dominant orthodox economic faith.

${ }^{36}$ Gramsci, 5.

37

Stephen Gill and David Law, "Global Hegemony and the Structural Power of Capital," in Gramsci: Historical Materialism and International Relations, ed. Stephen Gill (Cambridge: Cambridge University Press, 1993), 488. 


\section{Selecting A Few Good Technocrats}

Adherence to the Washington Consensus was encouraged by the IFIs by more than the need to create good will for negotiations. Peru's desperate need for reinsertion created a situation where the approval or disapproval of the IMF ended in selecting the kinds of technocrats who were chosen to represent Peru. However, the promotion of neoliberal technocrats as their preferred partners in negotiations might have been less the outcome of Machiavellian manipulation of the IFIs than simply a human liking for working with friends and allies instead of strangers. ${ }^{38}$ A preference for dealing with fellow technocrats who shared the same language, training, values, experiences and beliefs became a desire to work with former IMF and World Bank initiates on the shared project of neoliberal restructuring. Better to have the enthusiastic participation of colonial underlings who supported the project, than technocrats who would resist neoliberalism every step of the way and only grudgingly implement SAPs. The preference for working with former colleagues became a requirement, when the need for an agreement with the IMF was a desperate necessity for the Peruvian government. Difficulties in negotiations threatened the paramount goal of reinsertion into the

38

This fondness for working with former colleagues was expressed by IMF officials while conducting negotiations with officials in the government of India. Former World Bank and IMF officials had moved into key positions in the central government, and, not surprisingly, IMF officials felt that: "it has been on the whole easy to negotiate with Indian officials compared to other Third World countries, where you see a lot of grim faces across the bargaining tables. Economic thinking was in the same direction, their attitude has been most conciliatory." Chossudovsky, 132. 
international financial system and hence Fujimori's credibility as an economic manager. Any deal became the palatable outcome, whether or not that deal was in Peru's long run interests.

The necessity of having officials that the IMF felt comfortable in working with meant that neoliberal Peruvian technocrats were selected to lead the negotiations and hence guide the restructuring of the economy. Fujimori first selected members of cabinet to reflect the various political parties. Fujimori's first Minister of the Economy, Juan Carlos Hurtado Miller, had had previous experience in politics as Belaúnde's Minister of Agriculture. Hence he had political resources that were independent of both Fujimori and the IFIs. Thus at first Hurtado Miller's party affiliation was regarded as an asset. He designed and implemented the Fujishock, but then lost the confidence of Peruvians because of continued hyperinflation as well as the high social cost of the Fujishock.

Despite his orthodoxy, Hurtado Miller had found negotiations difficult with the IMF: " it was difficult to exchange ideas with them because they came with preset criteria that would be terrible to implement." ${ }^{\text {39 }}$ Hurtado Miller's reluctance to follow the line of the IMF meant that he did not have their support during the crisis, and then the IMF let it be known that they no longer trusted him "to be

Quote by Juan Carlos Hurtado Miller in Pilar Davila Perez, "La Vision de los Implemedores Politicas," en Implementacion de Politicas Publicas en el Peru, ed. Augusto Alvarez Rodrich and Gabriel Ortiz De Zevallos (Lima: Instituto Apoyo, 1995), 171. Translation by author. 
capable of leading Peru along 'sound' economic policy lines." ${ }^{40}$ He resigned. By contrast, the Director of the IMF made trips to Lima to support the neoliberal Boloña. Obedience had its reward.

Carlos Boloña had first met President-elect Fujimori during his fateful trip to New York. Boloña had moved his family to Connecticut in 1989 because of the economic collapse under García and the threat to his family's personal security posed by Sendero Luminoso. While in Connecticut, Boloña had been engaged in working as consultant for international banks and the World Bank. ${ }^{41}$ At the end of Fujimori's trip to New York and Tokyo, Boloña met with Fujimori, De Soto, Rodriguez Pastor, Aldofo Figueroa and Felipe Morris ${ }^{42}$ at Rodriguez Pastor's invitation in a hotel room in Miami. During the meeting Boloña debated with Figueroa over how to end hyperinflation based on his experience with Jeffery Sachs in Bolivia, a debate that Boloña felt was instrumental in convincing Fujimori to implement shock policies. ${ }^{43}$ What is important to note about this introduction, was that Boloña was introduced by a former economy minister

\footnotetext{
${ }^{40}$ Teivanen, 119.

${ }^{41}$ Interview with author, August 1997.

42
}

Hernando De Soto was an internationally renowned critic of government interference in the economy and informal markets, an advisor to Mario Vargas Llosa and the author of El Otro Sendero, (The Other Path). Carlos Rodriguez Pastor was a former Minister of the Economy under Belaúnde. At the time, Figueroa and Morris were Fujimori's official economic advisors and were neoKeynesian economists. Figueroa resigned shortly after this trip.

43

Carlos Boloña, Cambio de Rumbo (Instituto de Economia de Libre Mercado: Lima, 1995), 23-25. 
under Belaúnde (Rodriguez Pastor) and his claim to expertise was based on a connection to Jeffery Sachs and thus to the international hegemonic caste of technocrats connected to the IMF. ${ }^{44}$

In contrast to Hurtado Miller, Boloña cultivated excellent relations with international creditors. He instituted a neoliberal restructuring program whose zeal took even the IFIs by surprise ${ }^{45}$ Instead of a reluctant negotiator, the IFIs had found a fervent missionary. During his tenure in office, Boloña relied on the explicit support of the IMF at crucial moments to carry out his policies. For example, in the fall of 1991, the Peruvian Congress had passed various amendments to the budget which would have increased spending on public works, reduced taxes, and increased the deficit. In a meeting with Boloña at a World Bank conference, Camdessus expressed his concern that amendments passed by Congress to increase expenditures without equal tax increases had made Peru's economic plan unviable. At Boloña's invitation, Camdessus then travelled to Peru, and lauded increased taxes as an expression of social solidarity in public speeches. Taxes were increased ${ }^{46}$ The ability to call on the head of the IMF to visit Lima demonstrated to Congress that Boloña had the

44

While Jeffery Sachs later softened his support for SAPs, at the time he was the architect of a successful structural adjustment in Bolivia that finally tamed its chronic hyperinflation.

45

Javier Iguiñiz, "The Economic Strategy of the Fujimori Government", in Fujimori's Peru: The Political Economy, ed. John Crabtree and Jim Thomas (Institute of Latin American Studies: London, 1998), 28.

${ }^{46}$ Boloña, "The Viability of Alberto Fujimori's Economic Strategy.", 218-219. 
backing of the IMF.

Moreover, Boloña used negotiations with the IMF to insulate policy choices from pressure from organised domestic interests. For example, his reform to education was an initiative that went beyond the purview of officials from the IMF and World Bank. These officials did not understand why education was a subject of their negotiations with Boloña and why it was in the Letter of Intent. ${ }^{47}$ But Boloña understood that agreements with the IMF cast policy initiatives in stone and beyond domestic political interference.

The power of the technocrats and their dependence on connections with the IMF and World Bank, was most clearly revealed during the period of the autogolpe in April 1992. Even though the coup was a surprise to Boloña, and despite the threat to his personal wealth and liberty, he decided to remain in office. ${ }^{48}$ In his view, the continuation of the economic program was too important for the country for him to abandon the government and resign. But Boloña then used his status to demand that Fujimori call Constituent Assembly elections to prevent Peru from becoming a political "pariah"49. From his international contacts he knew that governing only by presidential decree was unacceptable. To escape international censure, Fujimori had to call Constituent Assembly

\footnotetext{
${ }^{47}$ Interview with author, August 1997.

48

The 1979 Constitution threatened coup participants with the confiscation of all their property. Boloña brought this up himself, as evidence of his heroism in deciding to remain in office after the coup. Interview with author, August 1997.

${ }^{49}$ Boloña, Cambio de Rumbo, 100.
} 
elections to draft a new constitution, even if that constitution removed all checks on the President's power. At this crucial juncture, Boloña was indispensable to Fujimori because his presence in cabinet signalled the continuation of the neoliberal economic program, a program around which the private sector and the military could coalesce. ${ }^{50}$

Furthermore, Fujimori needed Boloña's good relationships with the IFIs to insulate him from the unexpectedly strong international opposition to his coup. While the international community did exert pressure on Fujimori and threatened to impose sanctions, the record of the IFl's after the autogolpe was not so principled. The United States government signalled its displeasure by cancelling a scheduled meeting between President Fujimori and Assistant Secretary of State Bernard Aronson ${ }^{51}$ and suspended most bilateral aid. Germany cancelled a planned trip by the President to Bonn and announced that it would "review all economic cooperation with Peru. ${ }^{152}$ Boloña called on Washington to put pressure on Tokyo to suspend its aid as well. He wanted to eliminate Fujimori's illusion that since Japan had not already suspended its aid, it would come to his rescue without Constituent Assembly elections. ${ }^{53}$ Japan blocked $\$ 400$ million in

50

Alberto Adrianzen M., "Nuevo Modelo Asiático y veija República Aristocrá"tica?" en Que Hacer 76 (March-April 1992). This article was published just after the autogolpe and was illustrated with a picture of Boloña with the cutline: "He who laughs last, Boloña is now indispensable," 12-13.

${ }^{51}$ Cameron, Democracy and Authoritarianism in Peru, 154.

${ }^{52}$ Poole and Renique, 163.

${ }^{53}$ Cameron, "The Eighteenth Brumaire of Alberto Fujimori.", p. 65-66. 
previously arranged disbursements via the IDB. ${ }^{54}$ The vehemence of the universal chorus of condemnation over the autogolpe shocked and surprised Fujimori. In order not to be censored by the OAS, which had recently added a democracy clause to its charter, Fujimori agreed to constituent assembly elections.

However the Constituent Assembly and the subsequent Congress provided no check on Fujimori's power. The various incarnations of his movements had a majority in Congress, a majority he used to block any investigations into various scandals and eliminate limits on his re-relections.

But the IFIs communicated a different set of priorities from the major powers. At first, the IFIs followed the American lead, suspending all credits and loans. But at a meeting held to review Peru's status two weeks after the autogolpe, Michel Camdessus declared that the political situation was not "an issue" for the IMF. The US representative to the IMF lauded Peru for its "dedication" to the IMF's economic plan. ${ }^{55}$ Imposing a dictatorship was not an issue or problem. Once Fujimori agreed to Constituent Assembly elections, all was forgiven and the credit freeze of the IFl's was lifted.

At this delicate conjuncture in Peruvian history, the IMF indicated its true priority and purpose: economic orthodoxy was more important than democracy. According to Weber's theory of elective affinity, the aspects of an ideology that

\footnotetext{
${ }^{54}$ Poole and Renique, 163-164.

${ }^{55}$ Poole and Renique, 164.
} 
reflect the material interests of the dominant strata will be elected, while those that did not will be abandoned. ${ }^{56}$ In this case, the directors of the IMF elected the values of neoliberal orthodoxy, while abandoning the values of democracy. The true purpose of the IFIs was demonstrated: enforce the economic world order. The support of the IMF then became a political resource for neoliberal technocrats.

However while the IFl's provided critical political support for neoliberal technocrats during the struggle to implement structural adjustment, the support was for their policies not for their personal political ambitions. Boloña, for example, was removed from office by Fujimori as soon as Peru signed an agreement with the IMF in January 1993. He was dismissed presumably because he helped force Fujimori to call Constituent Assembly elections, and refused to stimulate the economy in the run up to the 1995 elections. His replacement as finance minister, Jorge Camet, was kept on a tight rein with only a six month renewable contract and was kept in office as long as he did not compete with Fujimori for the political limelight. ${ }^{57}$ As long as Fujimori kept the IFIs content, technocrats were eminently disposable and replaceable by the President. ${ }^{58}$ What was important to the IFIs was Peru's adherence to the policies

${ }^{56} \mathrm{H} . \mathrm{H}$ Gerth and C. Wright Mills, From Max Weber: Essays in Sociology (New York: Oxford University Press, 1958), 63.

${ }^{57}$ Carol Wise, Reinventing the State, ff, 220.

58

Fujimori was known for his constant cycling of technocrats in and out of office. They usually lasted about a year. Boloña only reappeared in cabinet at the end 
of structural adjustment, not the personnel who implemented them.

\section{Conclusion: Coercion becomes Consent, Domination becomes Hegemonic}

The tale of how the IFI's enforced their vision of neoliberal structural reforms on Fujimori and Peru revealed the process by which coercion became consent, how the domination of the IFl's became internalized as a set of hegemonic ideas in Peru. The power of the IFI's transformed a set of policy choices into an inescapable fate for Peru. Because the agreement of the IFI's was a precondition for any solution to Peru's economic catastrophe, the IFl's set these particular policies as the only alternative for Peru. TINA (There is no Alternative) was thus transformed from a justification for painful economic policies to a description of reality for Peru. Power created its own reality.

Moreover, within a political society in crisis, the IFl's were able to influence the selection of the right technocrats to impose a neoliberal order. What was also intriguing about the position of these cosmopolitan intellectuals, was the similarity between their relationship to their society and the relationship of the Caesarist dictator. Both lacked organic connections to the old economic, social and political elites. Their independence allowed them to ignore the material interests of the previous classes, to dissolve the means by which the old structures of power had been articulated, and to denounce the old mores that reflected the old class structure.

of Fujimori's reign, at a time when scandals over the election meant that Boloña's rapport with international creditors was needed again. 
But if the technocrats were the organic intellectuals of international hegemony, then the ideas and ideals they articulated reflected the material interests of the centre and not Peru's. The next chapter is an examination of how the policy changes implemented in Peru expressed the hegemonic discourse of the Washington Consensus and also reflected the material interests of the centre. 


\section{Chapter Five: The Washington Consensus;}

\section{A New Ideology, a New Global Economic Order and a New State}

The hegemonic economic ideology, the "Washington Consensus", was a connected series of policy reforms imposed as a universal set of prescriptions for all economies in the periphery to follow. Targets for policy reform involved a complete restructuring of the social relations of production, the relationship between state and society, and their economic relationship with the global economy. Structural adjustment programs were designed to diminish the power of the peripheral state, to increase the efficiency of production for the centre, and also to open up markets for the consumption of complex consumer goods. The implementation of the Washington Consensus resulted in a global consumer market married with the integration of global production chains. Thus, structural adjustment programs combined internal political and macroeconomic reforms with changes to the periphery's role in the external economic order.

In order to assess how the policies of the Washington Consensus completely restructured Peru, each of the major areas of reform will be examined in this chapter. Instead of examining Fujimori's record to ascertain how faithfully Peru took its economic medicine, or judging how successful these policies were at achieving their macroeconomic goals, this chapter seeks to explore the effects of the reforms on Peru. By exploring the effects of these reforms we can then understand who paid for the change, who benefited from the neoliberal order and for whom the new order was constructed. 
The policy choices of the Washington Consensus formed the basis for the reforms implemented in Peru for two reasons. First, as discussed in the previous chapter, Peru needed the imprimatur of the IFl's. Secondly, Boloña and the economic team followed the Washington Consensus as a "blueprint", a plan that could quickly reduce hyperinflation as well as entice desperately needed foreign investment. ${ }^{1}$

Obedience to the Washington Consensus and the reforms it entailed involved fundamental changes to Peru's underlying common sense and ideology, state, and relations of production in the economy. While the examination of policy areas will be divided into sections on ideology, state and economy, each policy also affected the other areas. This division is, as always, merely a heuristic device. Thus, in the first section, reforms to ideas and laws about private property will be explored as an example of how changes in policy expressed the imposition of hegemonic values and experience. Other policies also contain within them an ideological core specifically the policies that involved the restructuring of the economy.

The second section will involve an examination of how policy reforms transformed the purpose and composition of the Peruvian economy. While changes to tariffs and privatization were justified by appeals to economic efficiency, they had the effect of reorienting Peru's economy back into primary

1

Carol Wise, Reinventing the State Economic Strategy and Institutional Change in Peru (Ann Arbour: University of Michigan Press, 2003), 184. 
goods production in mining which benefited the centre.

The third section will examine how the power of the state to intervene in the economy and class relations was reduced. Reforms such as setting interest rates, strategic foreign exchange levels, deregulation, tax collection, general cutbacks in government spending and eliminating subsidies all involved the state renouncing its responsibility for economic outcomes and social peace.

Overall, this chapter will explore the underlying tension between the justification for policies and their very different consequences. Despite the fact that these policies increased debt loads, increased problems with balance of payments and failed to deliver economic prosperity, the policies continued to be promoted by the IFl's for the age-old reason that those whose interests were served by the reforms had the power to win. One of the ways the dominant classes in the centre won was by imposing its norms on the periphery through ideology.

\section{The New Ideology: Neoliberalism and Sacred Private Property}

The Washington Consensus not only involved structural economic and political changes, it also invoked underlying American values as universal values as part of a new hegemonic neoliberal world order. As we have seen, hegemony, in the Gramsciian sense, refers to a situation wherein consent is more dominant than coercion in relationships of power. ${ }^{2}$ Consent is manufactured or inculcated

2

Robert Cox, "Gramsci, Hegemony and International Relations, an Essay in 
through the invocation of values or norms that are articulated through an ideology. These values or norms in turn reflect the material interests of a dominant class within a society, or reflect the cultural values, norms and material interests of the dominant class of the dominant country when hegemony exists on an international scale.

To Gramsci, ideology was not a reflection of one person's idiosyncratic reflections, but an organic expression of one class's weltanschaaung, its mores, its ethos and its social relations. ${ }^{3}$ By inculcating its ideology as an ethos within subaltern classes, subaltern classes come to accept the rule of the dominant classes as just. Once these values are internalized and accepted throughout society they then form what Gramsci described as common sense, that set of values that could be invoked by the organic intellectuals of the dominant class to legitimate and replicate domination.

One example of how a cultural value or norm serves the material interests of the centre is the notion of the sacrosanct right to private property. As the dominant power, the values of the United States were infused into the IFIs, institutions that together defined the values of this international order. In American mythology, the right to private property is sacred, and private property

Method," in Gramsci, Historical Materialism and International Relations, ed. Stephen Gill (Cambridge: Cambridge University Press, 1993), 52.

3

Walter L. Adamson, Hegemony and Revolution: A Study of Antonio Gramsci's Political and Cultural Theory (Berkley: University of California Press, 1980), 151. 
rights were an unquestioned and unexamined precursor of a free society. ${ }^{4} \mathrm{~A}$ sacred right to property secures the rights of the American dominant class of corporate managers and owners to natural resources, markets and stock options. For the hegemon, once the right to property became accepted as a principle by the periphery, then even foreign ownership and control over the natural resources of the periphery was guaranteed. Peruvian decisions to enshrine property rights signalled that Peru would protect the rights of international capital and comply with the American imperium. Transnational corporations were able to mobilize bias in favour of property rights and appeal for American intervention to protect their interests. ${ }^{5}$ The American government was responsible for the enforcement of the American private sector's rights not just because someone's money was at stake, but because it was the government's duty to defend a sacred principle.

The American norm of the right to property was made international and

John Williamson, Latin American Adjustment: How Much Has Happened (Washington: Institute for International Economics, 1990), 17. Williamson himself reflected the unquestioning acceptance of the legitimacy of private property in his description of American attitudes: "In the United States property rights are so well entrenched that their fundamental importance for the satisfactory operation of the capitalist system is easily overlooked. I suspect, however, that when Washington brings itself to think about the subject, there is a general acceptance that property rights do, indeed matter." 5

The most infamous example of how private American businesses were able to invoke their rights to property in the name of anti-communism and demand protection from the American government was the United Fruit Company and the CIA coup in Guatemala. See Stephen Schlesinger and Stephen Kinzer, Bitter Fruit (New York: Anchor Books, 1983). 
given force when it became a condition for structural adjustment programs. The opening up of new markets for investment required a secure investment climate. To neoliberal theorists, the security of private property was the precondition for the possibility of liberty (see Chapter Two). To the ideologues of the IFIs, enshrining property rights signalled a country's willingness to participate in the international system.

In the twentieth century in Peru, land ownership was a contested political issue. From Velasco's land reforms to the land invasions that built the pueblos jovenes, private property did not have the same uncontested, unquestioned status as it did in American common sense. Thus while to the Americans the sanctification of property rights was merely a precursor to reasonable economic policy, in Peru property rights have been historically a crucial political issue.

Yet the shift of the right to private property to being a precursor of sensible economic policy involved a shift from domination to hegemony. When rights over property were left as a political issue, then foreign owned businesses secured their interests through coercive pressure. The most important Peruvian case involved a dispute in the 1960's with Standard Oil over back taxes owed on the La Brea y Pariñas oil field. ${ }^{6}$ The American government tried to put pressure on Belaúnde by suspending all aid and loans. The controversy later sparked the military overthrow of Belaúnde's government. But by shifting a contested political

6

David Werlich, Peru: A Short History (Carbondale: Southern Illinois University Press, 1978) 289-297. 
issue into a technical economic policy choice, the dispute over property rights was politically defused. Once property rights were accepted as common economic sense, then coercion could be replaced by consent and domination would shift towards hegemony.

One of the required policy reforms for Peru was enshrining property rights. Clarifying property laws was one of the crucial reforms which preceded privatization and opening up Peru to foreign investment. Property laws were expanded to include patent protection, ${ }^{7}$ which was the signal that Peru would agree to protect property rights and hence reintegrate Peru's economy into the international system.

\section{The Neoliberal Economy: Underdevelopment forevermore}

The policy prescriptions of the Washington Consensus went beyond merely guaranteeing property rights for international capital, they also opened up Peru for integration within the global economy. Tariff reduction refocused Peru's economy into primary goods production for export, while abandoning import substitution industrialization. Privatization of essential services and state enterprises effectively turned control over to international capital while also

Carlos Boloña, "The Viability of Alberto Fujimori's Economic Strategy", in The Peruvian Economy and Structural Adjustment: Past Present and Future, ed. Efrain Gonzales de Olarte.(Coral Gables: University of Miami, North South Center, 1996), 242-243. 
opening up Peru's mineral resources for foreign investment, development and profit repatriation.

The central structural adjustment policy that drove deindustrialization and reintegration was tariff reform. One of the standard prescriptions of the IFI's for structural adjustment was that tariff barriers should be reduced to a uniform lower level. The argument was that this would reduce imported intermediate input costs, and allow comparative advantage to set economic priorities. Local industry would also be forced to become internationally competitive, lowering domestic prices.

However, the elimination of differential tariffs also meant eliminating infant industry protection for Peruvian industry. The end of state-directed strategic protection marked the termination of state-led industrialization as Peru's development model and its replacement by an export oriented growth model. Those industries that were internationally competitive would, if only in theory, prosper, and new industries that catered to the centre's demand would lead to development.

However, like property rights, the effect of tariff reform was different depending on one's position in the global economy. The solution imposed on the periphery throughout the 1980's and 1990's was to lower import tariffs on industrial goods unilaterally, while the centre maintained its protectionist barriers for textiles and agriculture where the periphery did have a comparative 
advantage.$^{8}$ For the periphery, tariff reform meant accepting the market's discipline, while for the centre it meant opening markets for their industrial goods. But while opening tariff barriers unilaterally benefited the centre's industry, why would Peruvian technocrats have pursued policies that were to the detriment of Peruvian industry? Why did they not strategically select which industries should be protected as a starting point for developing an industrial base? Tariff reduction reflected the ideological premises of neoliberalism and its assumption that the outcome of the market is inherently just. In this view, those industries that failed to survive the shock of the loss of tariff protection were inefficient and had survived till now only through the corruption and interference of the state. As we have seen, the Minister of the Economy, Carlos Boloña, believed that Peru's economic problems were caused by protectionism and especially (in a term borrowed from Milton Friedman) "mercantilism" - basically the use of political influence to extract rent from Peruvian consumers through inflated prices. ${ }^{9}$ Protectionism, from this perspective, had allowed domestic industrialists to extract monopoly rents from consumers with inflated prices for goods of shoddy quality. Boloña justified his aggressive dismantling of tariff barriers, in the following statement:

8 Joseph Stiglitz, Globalization and Its Discontents (New York: WW Norton and Company, 2002), 60-61.

9

The term "mercantilism" of course predates Friedman. However, Friedman changed its meaning to denote using nationalism to promote protectionism and the establishment of a monopoly in a domestic market. 
Why should Peruvian consumers have to pay three or four times the international price for a car? The fact that domestic producers have more direct access to bureaucratic channels or politicians does not give them the right to obtain monopolistic profits or to cover their inefficiency at the expense of the people. ${ }^{10}$

The assault on tariff barriers was conducted by Boloña with an "almost fundamentalist liberalizing zeal", with a rapidity and radical nature that took even the IFI's by surprise, especially during a time when the currency was overvalued. ${ }^{11}$ Tariff barriers were aggressively dismantled as a central part of Boloña's economic strategy. In 1989 the average tariff was 66\%, but by 1992 tariffs were cut to an average of $16.1 \% .^{12}$ Non-tariff barriers were eliminated and tariffs were uniformly assessed at either $25 \%$ or $15 \% .{ }^{13}$ Tariff reduction was also a signal that the Peruvian state would not interfere with market forces, nor protect infant industries.

The reduction of tariffs resulted in a fivefold increase in consumer imports, which rose from $\$ 338.3$ million in 1990 , to $\$ 1.85$ billion in 1996 , a rate of expansion that was far beyond that of domestic production. ${ }^{14}$ Ironically, economic

${ }^{10}$ Boloña, "The Viability of Alberto Fujimori's Economic Strategy," 231. 11

Javier Iguiñiz, "The Economic Strategy of the Fujimori Government," in Fujimori's Peru: The Political Economy, ed. Jim Crabtree and Jim Thomas (London: University of London, Institute of Latin American Studies, 1998), 28.

12

Luis Abugattas, "Stabilization, Structural Reform and Industrial Performance" in. Fujimori's Peru: The Political Economy, ed. John Crabtree and Jim Thomas (London: Institute of Latin American Studies, 1998), 64.

\footnotetext{
${ }^{13}$ Abugattas, 64.

${ }^{14}$ Abugattas, 65.
} 
policies that were supposed to address balance of payment problems, instead resulted in an import surge for the benefit of northern exporters.

To Boloña, the drive to root out the tyranny of mercantilism was almost a religious crusade to reform the character of Peru, to break the "tyranny of the status quo" and rid Peru of the corruption of connections. Boloña's criticism of Peru's business practices as "mercantilist" was not without merit. Personal connections to the government meant access to favours: licences, subsidized credit, tariff exemptions, special exchange rates, monopolies in one's market that allowed producers to set high prices without reinvesting their profits to improve either productivity or quality. ${ }^{15}$ Boloña argued that these favours were the product of corruption. ${ }^{16}$ Business's profitability stemmed more from the favours that they could curry from the state the use of their connections to extract rents from the public rather than from efficiency. But instead of using tariffs to guide investment, the uniform elimination of tariffs meant that market forces would set economic policy, whether or not its direction led to development or dependency. Boloña's attitude to the difficulties of Peru's industrialists could be summed up this way: if Peru's producers could not survive sudden international competition, they did not deserve to continue in business.

${ }^{15}$ Teobaldo Pinzas, "Political Conditions, Economic Results, and the Sustainability of the Reform Process in Peru," in The Peruvian Economy and Structural Adjustment, ed. Gonzales de Olarte (Miami: North South Centre Press, 1996), 133.

${ }^{16}$ Carlos Boloña, Cambio de Rumbo (Lima: Instituto de Economia Libre Mercado, 1998), 51. While it is Boloña who explicitly labelled this corruption, it was a point of view also expressed by other technocrats in interviews. 
However, contained within the subtext of Boloña's writings lie interesting admissions of his class biases and an explanation of the source of his political support. The example that Boloña used to justify tariff reduction was the automotive sector. Tariffs were high to protect a small automotive sector based on assembling cars from imported parts. The elimination of tariffs reduced the cost of a car from $\$ 25,000$ to $\$ 7,000$, increased their variety and allowed Peruvians to purchase them in monthly installments of $\$ 200$ to $\$ 300 .{ }^{17}$ What Boloña failed to mention was that $\$ 200$ to $\$ 300$ was far beyond the income of most Peruvians. But for the elites, the fall in the price of automobiles was a significant benefit. The influx of suddenly affordable luxury goods like automobiles, effectively secured the political support of the middle and upper classes for neoliberal policies. Those who succeeded in the global marketplace were rewarded with Mercedes; those who did not lost secure employment and joined the marginalized informal sector of the pueblos jovenes and ambulantes or street pedlars.

Domestic producers faced with this sudden international competition were beset with other problems stemming from structural adjustment. At a time when domestic consumer demand was also compressed by the Fujishock, price controls and subsidies on basic goods were scrapped, real interest rates reached $40 \%$, taxes, especially payroll taxes, increased to $24 \%$ of gross

\footnotetext{
${ }^{17}$ Boloña, "The Viability of Alberto Fujimori's Economic Strategy", 231.
} 
production costs, while the currency appreciated $22 \%$ from 1990 to $1996 .{ }^{18}$ After the tariff shock, an estimated $20 \%$ of Peru's industrial enterprises went bankrupt, while the survivors had an idle capacity of $40 \% .{ }^{19}$ The industrial sector was faced with a lethal combination of increased competition, decreased domestic demand and increased taxes.

However, while the combination of these factors made it difficult for Peruvian industry to restructure and compete, it cannot be said that neoliberal policies de-industrialized Peru alone. The decline of the industrial sector had begun with the economic collapse under García, and de-industrialization under Fujimori was simply a continuation of previous trends. ${ }^{20}$ The shock of structural adjustment created a situation wherein while the economy stabilized and improved with the end of hyperinflation, the consumer durable goods sector continued its decline. For example, during the period of 1990 to 1997 , the production of televisions and radios declined by $47.04 \%$ while only $14.09 \%$ of installed capacity was utilized, and the production of other electrical household goods declined by $30.45 \%$, with a capacity utilization rate of $11.34 \% .{ }^{21}$ In order to survive, some firms transformed themselves from manufacturers to distributers

\footnotetext{
${ }^{18}$ Abugattas, 65.

19

Manuel Castillo Ochoa, "Fujimori and the Business Class: A Prickly Partnership" Nacla Report on the Americas XXX, no. 1, (July-August 1996), 27.

${ }^{20}$ Abugattas, 67.

${ }^{21}$ Abugattas, 73.
} 
of imported goods. ${ }^{22}$ Thus tariff reduction reinforced trends towards deindustrialization and a more backward integration of Peru within global consumption chains for the elite.

Tariff reduction, which was justified by neoliberals by the need to break the tyranny of the status quo, instead broke the industrial sector of Peru. Yet while this result was detrimental for the economy, politically it rewarded a consumer class with easier access to consumer goods.

The durable consumer goods sector that was weakened by the reduction of tariffs was also one of the centres of the traditional trade union movement. Thus, eliminating the industrial sector also undermined reform's political enemies. Bad economic policy for the long term development of Peru made good class politics.

The drive for privatization displayed the same ironic structure as tariff reduction: the ideological justification for privatization did not match the economic consequences nor the reasons that it was politically effective. Underlying the belief in privatization was a faith in the inherent superiority and efficiency of private enterprise. As John Williamson pointed out:"T(t)he main rationale for privatization is the belief that private industry is managed more efficiently than state enterprises, because of the more direct incentives faced by a manager who either has a direct personal stake in the profits of an enterprise, or is accountable

\footnotetext{
${ }^{22}$ Castillo Ochoa, 27.
} 
to those who do (emphasis added)."23 This conviction in free enterprise justified the transfer of public resources into private hands as an article of faith, without reference to whether or not the enterprises actually were more efficient, much less whether or not they actually served the public interest either more effectively or at all.

Privatization, when combined with the deregulation of foreign direct investment, became a directive to denationalize control of the economy of Peru. By definition, foreign direct investment was regarded, naively, as always beneficial. In Washington, barriers to investment were regarded as merely "foolish" barriers to technological innovation. ${ }^{24}$ The combination of privatization and ease of entry for transnational corporations meant that strategic sectors were transferred beyond national control.

But what was the economic effect of privatization and de-nationalization? At least in the short run, increased foreign direct investment had a beneficial impact on both government revenues and the balance of payments. By mid 1995, privatization had raised $\$ 3.6$ billion. ${ }^{25}$ During Fujimori's regime, some 220 companies were privatized for $\$ 9.2$ billion. ${ }^{26}$ Some $\$ 2.2$ billion had been spent

\footnotetext{
${ }^{23}$ Williamson, 16.

${ }^{24}$ Williamson, 15.

25
}

Carol Wise, "State Policy and State Conflict", in The Peruvian Labyrinth: Polity Society, Economy, ed. Maxwell A. Cameron and Philip Mauceri (University Park, Pennsylvania: The Pennsylvania State University Press, 1997), 88.

26

Barbara J. Fraser, "Peru: Hanging up on the Public Sector", NACLA Report on 
readying the companies for sale and only $\$ 4.4$ billion actually made it into government coffers. The difference vanished into sticky private hands and secret bank accounts. ${ }^{27}$ The revenue was used for general government expenditures, with asset sales worth 2 to $3 \%$ of GNP until Peru ran out of enterprises to privatize by the end of Fujimori's time in $2000{ }^{28}$ The foreign exchange generated by the sale of assets kept the foreign exchange rate artificially high which in turn generated more luxury good imports. Privatization also generated the foreign exchange required to pay off arrears to the IFl's, something Boloña had promised at meetings of the IMF and World Bank in Bangkok in October 1991. ${ }^{29}$ Unfortunately, this boon lasted only as long as there were assets to liquidate.

Privatization not only served as a revenue stream for the government but also helped build connections between Peruvian technocrats, IFIs and national and international capital. The sale of the telecommunication sector illustrated how the process worked. In mid-1991 The Minister of Communications and Transportation, Jaime Yoshiyama, formed a small team to examine increased investment in the phone system through the private sector. ${ }^{30}$ The team quickly

the Americas XXVI, no. 3 (January-February 2003), 40.

${ }^{27}$ Fraser, 40.

${ }^{28}$ Fraser, 41.

29

Teivo Teivanen, Enter Economism , Exit Politics (London: Zed Books Limited, 2002), 128-129.

30

Karina Izaguirre, "Privatizacion de las telecomunicaciones" en Implementacion de Politicas Publicas en el Peru, ed. Augusto Alvarez Rodrich and Gabriel Ortiz 
decided that foreign investment in the system was a necessity since local businesses lacked the capital and expertise required to modernize the system. ${ }^{31}$ The World Bank was brought into the process as consultants to the team, offering seminars on the international telecommunications industry which helped shape the legal structure for privatization. ${ }^{32}$ The participants in the final winning bid demonstrated the new structure of connections between international capital and local capitalists: the winning firm was Spanish with its local allies the financial groups Banco Weis, Backus and Johnson and Grana and Montero. ${ }^{33}$ Thus, the new comprador structure was revealed: control was transferred to transnational corporations with the participation of local financial groups. The new dominant bourgeois fraction within a new global neoliberal order was also revealed: an alliance of internationally connected technocrats combined with the financial haute bourgeoisie and transnational managers. Yet this dominant bourgeoisie fraction only came into being through the process of privatization.

The process of privatization also internationalized key services in the economy which included not only telecommunications and also transportation and electricity. ${ }^{34}$ One advantage to privatizing these services was that foreign

de Zevallos (Lima: Apoyo, 1995), 25.

${ }^{31}$ Izaguirre, 26.

${ }^{32}$ Izaguirre, 26.

${ }^{33}$ Izaguirre, 44.

${ }^{34}$ Wise, Reinventing the State, 192. 
capital was invested to modernize the equipment and services, as was the case with the telephone company. ${ }^{35}$ However, these services also tended to be natural monopolies. With the state averse to and incapable of regulating prices, prices rose above international levels. ${ }^{36}$ The end result of privatizing these services was to denationalize control over Peru's economy in return for a short term solution to balance of payments problems, a fiscal shortfall and the need for capital investment.

While the economy as a whole was reoriented to the centre through privatization, it also reinforced itself by undermining its political enemies. With the transfer of ownership from the state to the private sector, the state escaped politically responsibility for workers' job security and wage levels. Privatization was usually accompanied by shedding workers in the name of efficiency and the survival of the corporation. For example, after the state's assets in mining were privatized from 1989 to 1993 , employment in this sector shrank by 23,000 permanent employees and 10,000 temporary workers while output increased. ${ }^{37}$ Overall, by 1999, privatization resulted in former state enterprises shedding 120,000 jobs. ${ }^{38}$ Declining employment weakened unions and demobilized

${ }^{35}$ Fraser, 39-40.

${ }^{36}$ Wise, Reinventing the State, 192. 37

Carlos Portugal Mendoza, "La Restructuracion y Privatacion de la Mineria y Los Retos de la Sindicalismo" en Los Desafios Sindicales de la Reestructuracion Empressal, ed. Giovanna Larco Drouilly and Jose Marcos-Sanchez Zegarra (Lima: Plades, RPT, 1996), 109.

${ }^{38}$ Fraser, 40. 
workers (see Chapter Six for more details). Privatization worked politically because it disarticulated and disrupted previous political connections, connections built on employment through the state.

Besides ending the state's responsibility to its own workers and signalling a new openness to foreign direct investment, privatization signalled the end of state-led development. Under the military government of Velasco (1968-1975), the state was to drive development through its investment in strategic sectors transportation, water, steel, and power - in order to assemble the building blocks required for industrial takeoff. State investment was supposed to increase backwards and forward linkages in the economy, leading Peru out of the trap of dependency. ${ }^{39}$

However, the Washington Consensus held that state investment, instead of catalysing growth, simply politicized production and led to sectoral rentseeking through capturing subsidies. In this view, instead of responding to international market signals, state enterprises were run to maintain employment levels and subsidize political supporters. The cure for this problem was to privatize loss-making state enterprises, to depoliticize their employment levels to restore market discipline and hence efficiency. After the Baker plan of 1985, privatization became official US policy, and then the policy of the World Bank and IMF. Thus privatization as a policy signalled Peru's rejection of economic nationalism.

${ }^{39}$ Wise, Reinventing the State, 97. 
The place for Peru in this system was a return to its former role as a producer of primary goods. The IFIs' neoliberal economic strategy for growth in the periphery was for these countries to focus on their areas of comparative advantage. For Peru this meant a renewed emphasis on mining. The problem was that mining in the 1980's and 1990's was encouraged globally by the IFls through SAPs. Increased global mineral production had already caused a collapse in mineral prices relative to manufactured goods. According to Oxfam, the simultaneous global increases in commodity production by so many countries simply resulted in a global depression in their prices ${ }^{40}$ Relative terms of trade for primary goods versus manufactured goods dropped by $52 \%$ during the 1980 's. ${ }^{41}$ The danger for the periphery was that the primary goods in which they held a comparative advantage were goods that were faced with inelastic demand. Goods that have inelastic demand curves are products whose price has relatively little effect on their demand. For example, copper is used mainly in industrial processes, and a sudden decrease in its cost does not create a sudden surge in demand.

The problems with focussing on primary good production were especially true and especially stark in the mining sector. As we have seen, investment in mines did not lead to an increase but a decrease in employment: 33,000

40

Cited in Catherine Caulfield, Masters of Illusion: The World Bank and the Poverty of Nations (New York: Henry Holt and Company, 1996), 158.

${ }^{41}$ Caulfield, 158. 
positions were lost while output increased. ${ }^{42}$ But even new mines were not the answer to widespread unemployment, when one new mine cost $\$ 2.5$ billion to bring into production yet produced only 1,900 jobs. ${ }^{43}$ Mining was not the solution for Peru's need for employment. But the improved productivity from downsizing provided profits for the new transnational owners of these mines.

Who benefited from the structural adjustment of Peru? The centre gained new markets for its manufactured goods through the dismantling of tariff barriers. Privatization opened Peru up for new investment by transnational capital in services. Investment by the World Bank facilitated the harvesting of Peru's minerals by international mining companies. Peru's elites got to participate in this the latest "dance of the millions." 44

\section{The Neoliberal State: Sterilized Democracy}

While tariff reductions, privatization and encouraging foreign direct investment signalled Peru's reinsertion into global capitalism, other parts of the Washington Consensus required the reduction of the role of the state. In this view, state intervention was a source of corruption and merely deformed the

\footnotetext{
42 Portugal Mendoza, 113.
}

43

Francisco Sagasti, Pepi Patron, Max Hernandez, and Nicholas Lynch, Democracy and Good Government: Towards Democratic Governance in Peru (Lima: Agenda Peru, 2001), 78.

44

Eduardo Galeano's phrase the "Dance of the Millions" referred to the boom in Latin America of the 1920's, when foreign capital flooded into the natural resource sector, and the elites became rich on the proceeds. 
economy. Therefore the neoliberal state was to abandon attempts to direct and control the economy and to leave these tasks to market forces (see Chapter Two).

Instead of the state being used either for the accumulation of capital through corruption or to enforce the appropriation of labour through the convee, silence secured the interests of capital. In the Peruvian case, by reducing its own power, the state renounced its ability to regulate capital, to set terms in the national interest and to protect the interests of workers. With the state out of the business of directing the economy, then economic outcomes were no longer to be a political issue. Without this responsibility, the state could no longer secure consent through imposed class compromises or be used as a site for political redress for subaltern classes.

In reality, non-intervention meant capital could now set its own terms. This supposed lack of capacity of state power to direct the economy was ignored when it came to guaranteeing the rights of capital or when state power was required to secure payments to the IFI's.

However, it must also be conceded that the real threat of sanctions by the IFI's enforced the reduction of the size and scope of the Peruvian state. Even though in theory the state could still intervene in the economy or refuse to sell off assets, in practise, the IFI's vetoed that option.

Other policies in the Washington Consensus promoted this diminution of the role of the state. The adoption of monetarist interest policies, floating exchange rates, deregulation and slashing government expenditures together 
meant that instead of governments, the markets would rule.

In the case of interest rates, Peru was to follow monetarist discipline which meant that interest rates were to be market-driven and positive, or above the rate of inflation to encourage savings and reduce capital flight. ${ }^{45}$ The transition to market-driven interest rates discouraged political interference in the allocation of capital, and transferred that authority to the market. Also in times of hyperinflation, a sudden increase in interest rates, or shock, would collapse demand and end hyperinflation, albeit at the cost of a massive economic recession.

In the case of Peru, businesses already weakened by hyperinflation and the economic crisis were bankrupted by rapidly ratchetting up interest rates without warning. ${ }^{46}$ Those businesses that had tried to survive hyperinflation through borrowing capital for financial speculation were ruined by the return to positive interest rates which dramatically increased their debt loads.

In addition, turning over the setting of interest rates to the market had consequences for the political system. Governments could no longer use preferential interest rates to reward supporters. ${ }^{47}$ Nor could the state use preferential interest rates to encourage growth in strategic sectors like exports to promote economic development.

\footnotetext{
${ }^{45}$ Williamson, 13.

${ }^{46}$ Pinzas, 140.

${ }^{47}$ Interview with former Agriculture Minister under Fujimori.
} 
Another central structural adjustment policy for Peru was the abandonment of multiple exchange rates. Structural adjustment policies usually included the demand to let the market set a single, unified exchange rate. The theory was that interference in exchange rates led to distortions in the economy, usually because the state had pegged the currency too high to subsidize the importation of luxury goods and buy political support. In this view, a devalued exchange rate would enable peripheral economies to make the transition from import substitution industrialization to export oriented growth by reducing demand for imports and promoting exports. In the long run, this approach was expected to resolve the foreign exchange and debt crises.

Under García, multiple exchange rates were used to subsidize and support strategic sectors of the economy like agriculture and manufacturing that required access to foreign exchange for imports of machinery or other inputs. ${ }^{48}$ However, access to these preferential exchange rates was diverted into private hands through corruption (see Chapter One). Therefore, the remedy was to allow the exchange rate to float.

Neoliberal theory suggested that a market set exchange rate would devalue Peru's currency to its "natural" level and hence promote exports and discourage imports. However, in the Peruvian case, increased capital flows from reinsertion and privatization actually kept the exchange rate overvalued

\footnotetext{
${ }^{48}$ Wise, Reinventing the State, 161.
} 
throughout the 1990 's. ${ }^{49}$ But the political effect of floating the exchange rate and, just as importantly, ending preferential exchange rates, again involved the ceding of state power to the market.

Another central focus that involved the reduction of the role of the state was an attempt to implement deregulation. Deregulation as a general concept involved the dismantling of the state's capacity to control prices, set standards and control entrance into markets. The Washington Consensus was that overregulation prevented competition and was a source of bureaucratic corruption..$^{50}$ Bureaucrats used their discretionary powers to extort benefits from private businesses and thus to dismantle state power would end corruption.

In the case of Peru, neoliberal prognostications were accurate. Bureaucrats had used the power of regulation for peculation, extortion and corruption. The problem was that Peruvian officials were grossly underpaid. Businesses were dependent on the state for credit subsidies, access to preferential exchange rates price controls and control over labour. The result was a situation where it made sense for business to "cultivate" officials, while officials required the "gratitude" of business for their personal survival. ${ }^{51}$ In Peru regulation had been privatized through corruption.

Regulation also created artificial monopolies that allowed inefficient

\footnotetext{
${ }^{49}$ Wise, Reinventing the State, 184.

${ }^{50}$ Williamson, 16-17.

${ }^{51}$ Sagasti et. al., 69-70.
} 
enterprises to extract monopoly rents from the economy. Deregulation was intended to promote competition and increase productivity. Boloña's example of a successful use of deregulation to break a monopoly was a complete price deregulation and ending of monopolies for all forms of transport including buses and taxis. Boloña suggested that the lack of strikes and inflationary fare increases in this sector was a major success for this policy. ${ }^{52}$ Deregulation was supposed to break unjust monopolies based on the state by breaking labour.

While deregulation was supposed to end the private usurpation of benefits at public expense, the end to consumption subsidies was designed to end the public usurpation of benefits at private expense. One of the key populist means of distributing benefits to the general public was through the provision of universal subsidies for basic goods consumption. The government provided these subsidies not by underwriting their production but through controlling their prices. However, the consensus was that these indiscriminate subsidies had to be eliminated. In this view, the problem with subsidies for consumption was that they distorted the relative price structure of production and hence hampered economic efficiency while bankrupting the treasury.

However, while in the centre subsidizing the consumption of basic goods might be counter-productive, ${ }^{53}$ in the periphery, the shock of ending general

\footnotetext{
${ }^{52}$ Boloña, 231.

53

Arbitrarily reducing the price of commodities to subsidize consumption simply drives down production. Subsidizing production leads to overproduction and high prices, like European butter mountains and American sugar prices.
} 
subsidies on basic goods was quite harmful. In Peru, the price of cooking gas was increased thitty fold overnight in August 1991. The residents of Lima's pueblos jovenes could no longer afford to boil water and cook food, conditions which led to a cholera outbreak. ${ }^{54}$

Deregulation in the case of labour market reforms was code and camouflage for the elimination of wage protection, sector by deregulated sector. Especially in cases like Peru where unemployment and employment in the informal economy are so prevalent, deregulation led to an increase in the structural power of capital over labour (see Chapter Six).

While the general direction of structural adjustment policies was to reduce the capabilities and power of the state, one area where the state was to become more effective was that of tax collection. The state wanted to increase the collection of taxes to reduce the inflationary effect of government deficits. However tax increases were usually focussed on consumption to help the supply side, which in practise meant that increases were borne by the poor.

However, the reform of the tax collection system in Peru, whether or not it was inequitable, was necessary. Under the previous government of Alan García, tax revenue as a proportion of the GNP had declined from 14.1 per cent in 1985 to 6.5 per cent in $1989 .^{55}$ The collapse in tax revenues resulted in a deficit that

Michel Chossudovsky, The Globalization of Poverty (Halifax: Fernwood Press, 1998), 201.

55

Shane Hunt, "The Current Economic Situation in Long-term Perspective," in The Peruvian Economy and Structural Adjustment: Past, Present, Future, ed. Efrain 
sparked hyperinflation. The García government then imposed harsh austerity measures to cut spending and from 1985 to 1990 government spending fell from $\$ 257$ million to $\$ 137.23$ million, measured in stable 1986 US dollars. ${ }^{56}$

Hyperinflation was then cured by Fujimori's draconian cuts to subsidies and by a reform to tax collection.

Even by Peru's standards, the administration of taxes had descended into corruption and chaos. Wealthy individuals tried to come to under-the-table arrangements with friendly officials, only to fall prey to extortion. ${ }^{57}$ Others simply tried to bribe officials. Over 180 different taxes made tax interpretation an impenetrable jungle, and the private sector used this complexity to avoid paying taxes. $^{58}$

A completely new professional tax department Sunat, (Superintendencia Nacional de Administración de Tributaria), was created by Fujimori to reduce tax evasion and end corruption. Salaries were increased from $\$ 50$ a month to a more professional $\$ 1000$ a month, while 2,034 tax collectors were let go for corruption. ${ }^{59}$ The number of types of taxes were reduced to five, with an

Gonzales de Olarte (Miami: North South Centre Press, 1996), 38.

${ }^{56}$ Pinzas, 129.

57

Francisco Durand and Rosemary Thorp, "Tax Reform: The Sunat Experience," in Fujimori's Peru: The Political Economy (London: Institute of Latin American Studies, 1998), 211.

${ }^{58}$ Thorp and Durand, 211-212.

59

Carlos Castro and Veronica Zavala, "Administración pública," en 
emphasis on collecting the IGV, (Impuesto General de las Ventas, the general sales tax). The net result was an increase in tax revenue collected from 5 to $9.5 \%$ of GDP by December $1992 .{ }^{60}$ An increase in tax collection in turn decreased the inflationary pressure of the deficit, and helped to end hyperinflation.

In general, tax reforms shifted the burden to broadly based consumption taxes like the IGV. Neoliberals justified flattening marginal tax rates by arguing they would increase incentives to work, encourage investment and result in "fairer taxes." This was reflected in Washington's preference for a broadly based tax regime that had a moderate marginal tax rate. ${ }^{61}$ However, since the poor typically save less of their income than the rich, consumption taxes fall more heavily on them. Hence consumption taxes are regressive rather than neutral or progressive. In a situation of extreme (indeed obscene) inequality, tax reform further concentrated income in the pockets of the wealthy.

The irony of this situation was that, in theory, hyperinflation was supposedly caused by out-of-control government spending. In reality, hyperinflation was caused by out of control corruption and tax evasion. The initial cause of hyperinflation in Peru was García's attempt to reactivate the economy by increasing expenditures, increasing the minimum wage and manipulating the

Implementación de Politicas Públicas en el Perú, ed. Augusto Alvarez Rodrich and Gabriel Ortiz de Zevallos (Lima: Apoyo, 1995), 111.

${ }^{60}$ Boloña, "The Viability of Alberto Fujimori's Economic Strategy," 251.

${ }^{61}$ Williamson, 13. 
price structure without improving productivity or increasing production levels. ${ }^{62}$ But after the initial inflationary effect of reactivation, inflation then hyperinflation were stimulated by the stimulative effects of a collapse in tax collection. Indeed, when hyperinflation was at its worst in 1998 to 2000 under Garcia, government spending was slashed, but the deficits exploded as tax gathering vanished. The deficit was then reduced under Fujimori by a recreated state agency that was capable of collecting taxes and enforcing anti-tax evasion statutes as well as cutbacks in subsidies. The irony was that neoliberals cured hyperinflation by improving the capacity of the state to gather taxes rather than by their cutting government spending.

But what effect and intent did the reform of Peru's tax system have on its role in the global economy? Taxes were shifted to consumption from investment and capital, while exports were exempted from taxation. In effect, Peru followed the international model whereby taxes on corporations were lessened and transferred to personal consumption while social expenditures were reduced. Thus international capital escaped the cost of the reproduction of labour through taxes that supported education and health care. The net effect was to lower the costs of production for primary goods in Peru, which lowered costs for the global market.

However, despite the source of the problem in tax collection, ideology dictated a reduction in government spending to reign in the deficit. To the IFIs,

${ }^{62}$ Chossudovsky, 196-197. 
the standard culprit for the deficit was overspending, not under-taxation. Fiscal deficits were regarded as the primary cause of inflation, balance of payments difficulties and capital flight. In this view the underlying cause of the deficit was a lack of political discipline to match expenditures with revenue.$^{63}$ Therefore, to the IFIs, government spending must always be slashed no matter how great the need or minuscule the spending.

However, the desire to control government spending became, in effect, a means to camouflage the restructuring of the role of the Peruvian state. The state cut back on its provision of social services like education, health care and poverty alleviation. Throughout the twentieth century, the Peruvian state had sought to reduce class conflict through the state's provision of services. The state had incorporated subordinate classes by ameliorating conflict, and imposing general wage settlements. ${ }^{64}$ Yet these settlements did not mark a Fordist class compromise where workers accepted rule by capital in exchange for higher wages and a regularization of power relations through collective bargaining and the recognition of unions. Instead, the Peruvian state had redirected class conflict from the economy into the state as the site for class struggle. Rather than a direct conflict with employers, conflict was redirected into a struggle to acquire goods and services from the state through political

\footnotetext{
${ }^{63}$ Williamson, 10.
}

64

For a detailed account of the history of the Peruvian State's involvement in labour relations, see Chapter Six. 
bargaining. The usual method to secure political support was the populist distribution of goods and jobs. But by the end of García's term, the state had run out of resources for populist redistribution (see Chapter One.).

So outside of the draconian social impact of the Fujishock, there was an important symbolic and political purpose to the cutbacks: the state was no longer taking responsibility for the well being of its citizens. The state did not secure consent through the universal provision of services, nor did it guarantee its citizens access to basic goods. The state was not responsible for the imposition of a class compromise between the dominant elite and subordinate classes. Instead the state's capacity and responsibility to regulate capital and interfere with market forces was expunged. The new model required a state incapable of interfering in distribution, since increased inequality and focussed consumption were characteristic results of neoliberalism.

Yet at the same time as the state abandoned its major responsibilities for overarching goals, Fujimori resorted to neo-populist distribution to win support. With the recovery of the economy after 1992, tax revenues increasing from SUNAT (see above) and the proceeds from privatization, the office of the presidency had resources to distribute. The president personally delivered satellite dishes and computers via helicopter to remote communities through what has been described as "techno-populism." ${ }^{15}$ But this techno-populism did

65

Carlos Iván Degregori, José Coronel and Ponciano del Pino, "Government, Citizenship and Democracy: A Regional Perspective," in Fjimori's Peru: The Political Economy, p. 245. 
not set relative prices, change rural urban relationships, offer permanent rights to resources, nor did it alter power relations between classes. Techno-populism provided pictures for the nightly news of the President taking action without actually challenging anything.

But despite economic recovery and despite reinsertion into the international financial markets, income disparities remained high. Historically, Peru has had one of the world's greatest levels of income disparity. Since the conquest, opulent wealth for the few has been paid for by the starvation of the many. In the mid-1970's, Peru had one of the highest Gini coefficients in the world, while the trend from 1950 to 1980 was for an even greater level of income concentration. ${ }^{66}$ Under Fujimori and neoliberalism, the situation for the poor was still dire. Underemployment levels were steady at $77.6 \%$ of the population, when underemployment is defined as receiving wages below the level of subsistence. ${ }^{67}$ One of the results of structural adjustment was an increase in inequality. ${ }^{68}$ In Fujimori's Peru, few prospered, while many just tried to survive. The new neoliberal order and its inequality looked less like a new version of oppression than a return to an age old pattern of exclusion.

Wage compression was driven by IFI-dictated demands for reforms to the

66

Aldolfo Figueroa, "Income Distribution and Inequality in Peru," in Fujimori's Peru: The Political Economy, ed. John Crabtree and Jim Thomas (London: Institute of Latin American Studies, 1998), 138.

${ }^{67}$ Figueroa, 137.

${ }^{68}$ Sagasti et. al., 32. 
labour market. Under the rubric of flexibilization, IFIs and neoliberal technocrats sought to reform labour markets to improve the "mobility" of labour. The argument was that labour market rigidities had made Peruvian producers uncompetitive in global markets. This justified the dismantling of protection for labour under the labour code, which led to the compression of wage costs (see Chapter Six for a more thorough examination of how labour market reforms disguised an assault on wages).

But slashing wages to increase competitiveness did not result in a massive increase in employment. Those working in low wage export zones formed only a small part of the labour force. Peruvian workers could not hope to compete with wage rates in China.$^{69}$ In the areas of Peru's comparative advantage in mining, increased capital investment meant a declining need for labour. Those in the informal sector remained marginal to international production cycles, even as a reserve army of labour. These Peruvians were neither workers for international capital, nor did they provide a mass market for its luxury products.

Under neoliberalism, the purpose of the state changed from regulating capital and labour to balance demand and supply to drive development, to excluding the marginalized by dismantling their avenues of access to the state. Instead of the state seeking to regulate capital and extract surplus value for

69

Opinion expressed by an official in the Peruvian Labour ministry in an interview with the author. 
reinvestment in human and social capital, the state's direction changed to the reduction of taxes so that Peru would be internationally competitive.

\section{Conclusions: Structural Adjustment and the Neoliberal State}

Structural adjustment programs as imposed by IFIs were a set of mutually reinforcing policies that utilized neoliberal ideology and restructured the state to reinforce and serve a new neoliberal relations of production within the economy. Neoliberal ideology legitimized the new economic structures with its sanctification of the market, private property and entrepreneurship. Instead of being concerned about increased inequality that resulted from the economics of neoliberalism, neoliberalism celebrated wealth as the rewards of the worthy. Indeed, the discourses and policies of Fujimori's government around economic problems were to emphasize individualism and individual effort as the only solution. ${ }^{70}$ The state was not condemned for its failure to deliver services. Instead, the state was condemned for attempting to deliver services and interfere with the market. Thus neoliberal ideology validated new relations of production while it also justified a neoliberal state.

But if the neoliberal state did not provide the services that redistributed wealth and hence promoted a class compromise, what did this form of the state accomplish? A state that abdicated responsibility for market outcomes protected the interests of capital through silence. Abandoning regulation effectively

\footnotetext{
${ }^{70}$ Sagasti et. al., 32.
} 
neutered the state as a site of resistance for subaltern groups, since the state in this new order would never intervene, at least on behalf of workers. The IFIs had created a state that could do nothing but enforce the rule of the IFIs and guarantee the interests of local and international capital.

A series of contradictions between the neoliberal policies of the Washington Consensus and the interests of Peru were quite clear. Yet these contradictions are resolved by understanding that the interests of the centre were served by the restructuring of Peru via structural adjustment policies. Here structural affinity is illuminating, for the theory describes a process whereby certain aspects of an underlying ideology would be winnowed out or elected. Those elements that were elected were those that reflected the interests of the centre, not the periphery. Thus, despite the failures of neoliberalism to promote economic development or equity in the periphery, the Washington Consensus survived because it did serve the centre's interests and the institutional interests of the IFl's. Interest payments were paid, Peru's market was opened; its natural resources were sold off to transnational capital which then repatriated the profits. However, while international pressure from the IFI's meant that there was no alternative to neoliberal change, these changes affected more than the structure of government. These changes also transformed labour relations, the subject of the next chapter. 


\section{Chapter Six: The Disarticulation of Labour}

A key aspect of the restructuring of Peru within the program required by the IFIs was the crippling of a once politically powerful labour movement. As we have seen, previous attempts at imposing neoliberal reforms had foundered because of mass resistance spearheaded by the labour movement. Yet in spite of the opposition of labour, Fujimori was able to restructure Peru along the lines of the Washington Consensus. What had changed in the political conjuncture of Peru that had left labour so weak and politically vulnerable?

The political power of the labour movement was dependent upon a series of carefully articulated relationships with political parties, union leaders, the grassroots and the broader working class. What happened to the political power of the labour movement was that each of these relationships had fallen into crisis just when Fujimori took office. In order to understand why these relationships were undermined by the economic and political crisis, this chapter will first explore the history of the labour movement in Peru. The examination of the evolution of the relationship between the state and labour will show how labour became dependent on the state for its victories, and hence was particularly vulnerable to the changes in the role of the state demanded by neoliberal restructuring. The connections between political parties and the labour movement will be discussed next in order to understand how an alliance that had driven the labour movement became counter-productive when the political parties imploded (see chapter one). The crisis of representation between every established political party and Peruvians was a reflection of a deeper crisis of 
confidence in the ability of political leaders to find a way out of the crises besetting Peru. Peruvians no longer trusted their leaders either to lead or even to describe a vision for the future. The self destruction of labour's political representation mattered because it left labour without a political voice to articulate a vision different from neoliberalism.

Similarly to the crisis of representation in Peru's parties, the labour movement also suffered from a crisis of representation between its own leadership and its membership. This chapter will examine the causes of the breakdown in support for the leadership in order to demonstrate that this collapse was not merely the reflection of a loss of confidence in individual leaders, but also a collapse in belief in the overall project of state-led industrialization articulated by these leaders. Hence the weakness of the labour movement was not caused by any individual's errors but by its composition within an entire order that had failed.

The structural flaws of the labour movement were not the only cause of the political weakness of labour; Sendero and the security forces had also targeted its leadership cadre. Also, at the very moment when the labour movement suffered from a historic crisis in representation, neoliberal policy reforms erased the economic, social and political structures and spaces within which unions had developed. Neoliberal reforms created a power structure for labour relations that was heavily biassed against unions.

But why did this crisis of representation not simply lead to a new generation taking over from the unions' failed leaders? Neoliberal technocrats 
prevented the rebirth of the labour movement by privatizing and shutting down sites of unionized employment while creating a political climate that was indifferent to the problems of unions. However the main method to immobilize the union movement was to rig the game of collective bargaining against them. Hence the neoliberal project protected itself from a reorganised labour movement forming the nucleus of popular resistance as it had in the past. A weakened labour movement was then incapable of defending its members from demands for cuts to wages and benefits. This shift in the balance of forces then allowed capital to compress wages and pay for reigniting capital accumulation. Thus, the labour movement was politically neutralized to prevent resistance against how neoliberalism increased profits by gutting workers' share.

This chapter will explain how it was possible for the state to impose changes to the labour code to the detriment of unions which in turn changed the balance of power in the workplace. This led to the rearticulation of social relations of production in a new neoliberal form that was dependent on flexible and easily disposable workers. A new state structure was created to enable a new method of regulating the cost of labour.

However, the crucial revelation of this chapter is the extent to which the destruction of Peru's labour movement was self inflicted. While neoliberal reforms prevented the resurgence of the union movement, most of the original destruction of the unions was caused by their own history and their own internal contradictions. 


\section{The Disarticulation of Labour: Conjuncture and Contradictions}

Even though neoliberal policies directly threatened their interests and despite a history of successful resistance and political involvement, the labour movement was unable to veto the implementation of neoliberal policies under Fujimori. The factors that fatally weakened the labour movement were either contradictions that were inherent within the labour movement or were merely conjunctural or external to how the labour movement was formed.

Conjunctural factors were those threats to the labour movement that appeared outside either labour's position in the economy or the internal faults and failings of the labour movement, or the structural positions of power relations inherent to capitalism. Conjunctural threats were those that appear as a mere accident of history, albeit ones that happened at the worst possible time for labour.

But it was the weaknesses that were inherent in the Peruvian labour movement, from its composition within a failed economic order that left it especially politically vulnerable. Labour unions, like all organisations, reflected the times and the social and political structures within which they were formed. Labour unions formed within the workplaces of state-led industrialization reflected the power relationships, the conflicts, the ideas and ideals of that place and time. Unions in Peru fought long and hard for permanent job security for all workers, partially because this privilege was how empleados or white collar 
workers had distinguished their social status from that of the obreros, the blue collar workers. ${ }^{1}$ The tradeoff was supposed to be security for workers in return for a stable labour force.

It was the combination of both conjunctural threats and its internal contradictions that resulted in the disarticulation of the labour movement. This use of the term "disarticulation" refers to modes of production theorists' dual sense of the term articulation, with its dual meaning of "giving expression to" and "joining together". ${ }^{2}$ In this case, articulation would refer to how the unions both performed their functions within a particular order for Peru's economy and society and gave expression to or articulated a vision of how things worked.

Disarticulation then refers to the dual dislocation of the union movement, as they lost both their position in the economy and their ability to articulate a clear alternative vision to neoliberalism for Peru. Yet this disarticulation stemmed less from the failures of its individual leaders, than from a more profound dislocation as the place of unions disappeared as the overall order they had been created within was dissolved by structural adjustment.

1

This distinction was important in the formation of the idea of a middle class. See D.S. Parker, The Idea of the Middle Class: White Collar Workers and Peruvian Society 1900-1950 (University Park, Pennsylvania: Pennsylvania State University Press, 1998) for a complete discussion of the formation of this class. 2

David F. Ruccio and Lawrence H. Simon, "Radical Theories of Development: Frank, the Modes of Production School and Amin," in The Political Economy of Development and Underdevelopment, $4^{\text {th }}$ edition, ed. Charles K. Wilber (New York: Random House Business Division, 1988), 146. 


\section{Inherent Contradictions within Peruvian Labour}

The explanation for labour's political failure lay first within a reinforcing set of contradictions that were internal to the formation and the structure of the labour movement. Some of these contradictions were rooted in the historic formation of the unions and their relationship with the state.

The formation of Peruvian unions had specific characteristics that left them vulnerable to neoliberal reformers - specifically an excessive dependence on state intervention in labour relations as well as a history of political parties colonizing the labour movement for their own benefit.

When the Peruvian labour movement was formed from 1910 to 1930 , peaceful strikes against individual employers would have been suicidal for Peruvian workers. Impoverished workers could not survive a long strike and the low skill structure of Peruvian industry meant that strikers could be easily replaced by agricultural migrants from the Sierra. ${ }^{3}$ Instead of confronting individual employers, workers instead used direct actions like sabotage and mob violence as well as paros (the general strike) to create a climate of crisis and force the government to intervene and impose new standards. This strategy worked. In January 1913, President Billinghurst imposed a settlement for the Callao dockworkers which included an eight hour day. Later that month,

David Werlich, Peru A Short History (Carbondale: Southern Illinois University Press, 1978), 140. Structural mass unemployment remained a permanent feature of Peru's labour market throughout the rest of the century. The availability of desperate replacement labour meant that the collective bargaining strength of unions at the individual enterprise level was always weak. 
Billinghurst made collective bargaining obligatory, legalized peaceful strikes and provided for the democratic organization of unions. ${ }^{4}$ In January 1919, a three day general strike resulted in President Pardo's decree of the eight hour day as the legal norm for everyone. ${ }^{5}$ Since the strategic disadvantages for labour unions did not change during the rest of the century, successful strikes against individual employers were impossible, but if enough chaos was caused, the state might intervene and grant victory.

The entire history of the expansion of labour rights in Peru was driven by what James L. Payne described as "political bargaining." ${ }^{16}$ The strategy of the labour movement was to create a political crisis through mass demonstrations, general strikes and political violence. The government would then intervene, impose a settlement and grant concessions to the labour movement in return for social peace. Even in the case of individual enterprises, the most successful tactic for labour was to provoke state intervention since the state would impose favourable settlements on employers. Throughout the rest of the twentieth century the major gains for the labour movement came from attempts by governments to buy the support of workers either through populist decrees or through recognizing unions.

\footnotetext{
${ }^{4}$ Werlich, 135.

${ }^{5}$ D.S. Parker, 70.

6

James L. Payne, Labour and Politics in Peru: The System of Political Bargaining (New Haven: Yale University Press, 1965), 11.
} 
The history of the relationship between workers, unions and the state in the twentieth century reveals a pattern of pendulum swings between populist bribery for the masses while unions were repressed, followed by brief attempts at inclusion during democratic interludes followed by repression and then further failed attempts at co-optation. Various dictators, from Augusto Leguia, to Benavides to Manuel Prado to Manuel Odria ${ }^{7}$ to Velasco favoured anti-Aprista, usually Communist, unions in an attempt to tame worker unrest .

Accommodation was driven by the need to defuse the threat posed by APRA, a populist mass party that had organized workers into the first labour confederation and controlled most of Peru's unions. APRA's rhetorical appeals to violence and its ability to mobilize and recruit the nascent working class and rural indios (those with native ancestry who still lived in their traditional villages) terrified the Peruvian elites. ${ }^{8}$ These elites then supported and demanded a crackdown on APRA.

The problem was that Haya de la Torre, APRA's founder and "maximum" leader, concentrated all power in his own hands. This meant that APRA cadres represented APRA to the working class, the working class did not select their own leaders, and policy was defined by Haya de la Torre. Thus APRA did not organically represent the working class. Instead APRA colonized the unions to

7

Victor Alba, Politics and the Labour Movement in Latin America (Stanford: Stanford University Press, 1968), 268.

${ }^{8}$ Collier and Collier, 151. 
generate mass support, the masses did not create APRA to represent them.

The danger with this pattern of incorporation was that political parties like APRA used their unions as political tools, rather than as a means to understand workers demands and then represent those views in the political arena. For example, a paro was called by APRA in 1947 to protest a boycott by opposition Senators who represented elite interests. This boycott was designed to deny APRA a quorum, and hence veto APRA's legislative program. But the key measures blocked by the boycott included elections to municipal office and a contract for oil exploration, measures that while they were important, did not involve reforms for workers. APRA had used its control over the union movement as a political weapon for APRA's power, and not as a means to enforce worker's demands. APRA used unions to control labour, labour did not use unions to serve themselves.

The unions were undermined by their relationship to political parties across the political spectrum. The traditional strategy of the political parties for the labour movement had been to create their own labour federations and unions over which they exercised control. ${ }^{9}$ Parties dominated their unions by controlling access to jobs and elected positions within them. This meant that labour's leadership cadre was beholden to their political patrons, not the rank and file. This top-down structure within unions meant that unions articulated the party line

9

Carlos Monge, "De Gremios y Partidos en el Peru," en Arguementos (July 1995), 10-11. 
to their members rather than acting as a funnel for the political demands of their membership to their political parties. Political parties had their own labour confederations, with APRA controlling the CTP, and the Partido Communista controlling CGTP (Confederacion General de Trabajadores del Perú, the largest and most powerful trade union confederation) and the PPC (Partido Popular Christiano) controlling the CATP (the smallest and least influential confederation). ${ }^{10}$ The result of this colonization was a labour movement riven by sectarianism and factionalism, manipulated by their political masters in endless squabbles over the spoils of office. ${ }^{11}$ Thus at a time when Fujimori threatened to annihilate labour, the labour movement was divided by internal political factionalism.

The democratic regimes of Prado (1956-1962) and Belaúnde(1962-1968) featured an end to repression and the growth of the labour movement. In return for APRA's political support, Prado's government favoured Aprista unions over communist unions, with the result that the proportion of memberships in unions under Aprista control increased from $75 \%$ in 1957 to $90 \%$ in $1961 .{ }^{12}$ APRA used its political clout to deliver a more universal pension plan for workers in 1961 as well as land for union headquarters. ${ }^{13}$ Thus democratically elected governments

\footnotetext{
${ }^{10}$ Interview with Peruvian labour lawyers attached to a labour think tank.

${ }^{11}$ Monge, 10.

${ }^{12}$ Collier and Collier, 480.

13

Payne, 80-85. The Bill was the work of Senator Salas, an APRA labour leader for textile workers.
} 
attempted to incorporate rather than repress APRA and its labour unions. For unions during democratic periods loyalty to APRA resulted in access to political power and gains.

A radical break in the relationship between the labour movement and the state occurred under the military governments of Velasco (1968-1975) and Morales Bermudez (1975-1980). Instead of completely repressing the labour movement and forcing it underground, General Velasco's government actually tried to include labour. Velasco encouraged the formation of unions associated with the CGTP, the communist labour confederation, and not those associated with APRA. ${ }^{14}$ A strong union movement then led the struggle for a return to democracy when Bermudez took power.

This was the foundational moment for the leadership cadre of the labour movement which existed when Fujimori came to power. Labour led two massive paros against President Morales Bermudez (1975-1980), paros which led to the end of dictatorship and the transition to democracy under Belaúnde.

But from this formative experience, labour leaders learned the wrong political lessons. Radical middle class members of the Left led the drive to organise the new industrial sectors during the 1970's under an ideology based

14

The headquarters of the CGTP in Lima features a large portrait of General Velasco in the lobby. It was during the government of Velasco that the CGTP overtook the CTP (Apra's confederation) as the largest and most important labour confederation in Peru. The CGTP was affiliated with various Communist trade unions. 
on la lucha (the struggle) and clasista rhetoric. ${ }^{15}$ Left parties identified and trained new labour leaders as part of a broadly based strategy to radicalize the working class and revolutionize Peru. The union leadership cadre believed that they were the vanguard of a mass movement with strong links into society. They also assumed that the urban proletariat, as represented by the labour movement, could overturn regimes and form the vanguard for a class revolution. From this viewpoint, any attempt to compromise or negotiate with management was a sign of weakness. ${ }^{16}$ Their assumption was that the labour movement was more legitimate and had more support than the regime. The experience of the 1970 's for labour activists was that political activism could defend the interests of their members and force the state to accommodate their demands.

Unfortunately for labour, once democratic regimes took power, each of these lessons proved false. Under the military dictatorship, unions were the only legal organisations that could articulate the demands of the people and could spearhead resistance. But when the dictatorship was replaced by democracy, political parties replaced labour as the primary locus for identity, allegiance and power. Once democratic elections took place in 1980, the locus for broad alliances with other actors in civil society shifted into parties and politics, leaving

15 Jorge Parodi, To be a Worker: Identity and Politics in Peru (Chapel Hill: University of North Carolina Press, 2000), 139.

${ }^{16}$ Parodi, 142. 
the labour movement as just one more site for participation. ${ }^{17}$

In addition, thanks to the depredations of Sendero, the notion that the labour movement formed the vanguard of the revolution became a negative image. Revolution was associated with violence and chaos and thus became politically unpalatable. ${ }^{18}$ In a similar process to that which defenestrated the Left's political parties (see Chapter One), the factionalism and revolutionary rhetoric of the labour movement only alienated those they claimed to represent. The symbolic message that the labour movement was at the forefront of la lucha left the movement responsible for the chaos of Sendero.

Once a democratic regime was installed, it possessed its own sources of legitimacy that superseded solidarity to the movement. A paro called against the military regime of Bermudez became a mass expression of the desire for democracy supported across class lines, but a paro called against a democratic regime was something else. Later, when President Fujimori had an approval rating of $60 \%$, a paro called against the government was portrayed by Fujimori as an attempt to undermine the democratic will of the majority (see Chapter One).

Furthermore, the very openness of the democratic system worked to its

17

Martin Tanaka, "From Movimientismo to Media Politics: The Changing Boundaries between Society and Politics in Fujimori's Peru," in Fujimori's Peru: The Political Economy, ed. John Crabtree and Jim Thomas (London: Institute of Latin American Studies, 1998), 234.

18

Patricia Oliart, "Alberto Fujimori: "The Man Peru Needed?," in Shining and Other Paths, ed. Steve J. Stern (Durham: Duke University Press, 1998), 422-423. 
advantage since social conflicts were dispersed below peak levels. Once unions were legalized under democratic regimes, then disputes could be settled legally at the individual enterprise level. Thus the openness and legitimacy of democratic regimes served to diffuse support for the labour movement as a political actor, as the membership's support became diffused amongst various parties. ${ }^{19}$ Finally, as this thesis will demonstrate, as the power of the labour movement to threaten political mass actions disappeared, so too did its power over government. Thus, the lessons of the 1970 s directed the labour movement into a political dead end.

In the 1980 s and early 1990 s, the leadership of labour expressed what Martin Tanaka termed movimientismo, wherein leaders expressed maximalist demands for redistribution from the state, and labour unions used the strike to build a mass movement that they expected would lead to the revolution. ${ }^{20}$ During this time labour leaders competed for support of other grassroots organisations by trying to be more extreme and hardline than the others. As the crisis worsened in the 1980 's, the clasista ideology of the leadership led them to try to resolve problems by escalating conflict, a strategy which led only to repeated defeats. ${ }^{21}$ Thus Jorge Parodi, a Peruvian sociologist, observed that:

19

Carmen Rosa Balbi, "Situacion del Movimiento Sindical Peruano", en Movimiento Sindical: Una Propuesta para el mejoramiento de la calidad de vida. (Lima: Plades, 1993), 78.

${ }^{20}$ Tanaka, 234.

${ }^{21}$ Parodi, 142. 
This belligerent radicalism became a source of immobilism in the workers' movement. Clinging to its glorious radical past, the workers' movement was unable to develop a realistic strategy in the context of the economic crisis of the 1980's. Ultimately, the dynamic of distrust and antagonism was replicated in the divisions among workers - in the conflicts that involved the demands of skilled workers, the treatment of dissenters, and the partisan divisions amongst clasistas. ${ }^{22}$

The problem was that the state was bankrupt and had no resources to distribute. Instead of protests and paros building a movement for change, they simply alienated the popular sector by increasing chaos.

By the early 1990's political bargaining became counterproductive when political strikes failed to generate support; they simply signalled labour's impotence against capital. But under neoliberalism, the solution to class conflict was to remove the state from interfering in labour relations and to allow market forces to set wage rates and benefits. From the standpoint of neoliberalism, labour had unduly benefited from state intervention, and market discipline would now eliminate privileges extorted by political interference. The state would neither intervene to repress labour, nor would it intervene to force a settlement on capital. The state would neither repress class conflict nor mediate solutions. It would remove labour relations from the political sphere by ignoring them.

Once the state was ideologically committed to non-intervention in labour relations, the habitual forms of labour activism became pointless. Paros and protests simply proved that privileged workers were rightly losing their rents and an act that was meant to force the state to retreat simply proved to reformers

\footnotetext{
${ }^{22}$ Parodi, 142.
} 
that they were on the right track.

One of the crucial subtleties of the neoliberal order was that it did not simply attempt to abolish through repression the labour movement. At various stages of Peru's history - for example under Benavides, Leguía and Odria - an authoritarian state had attempted to eradicate the labour movement, confiscating some of its property and incarcerating some of its leaders. The result was that the labour movement went underground, only to emerge stronger when the dictatorship inevitably fell. Under neoliberalism, while unions remained legal, labour relations were designed to make it effectively impossible for unions to represent the interests of their members. This meant that instead of the labour movement forming the focus of resistance to overt repression, they had to struggle against employers in a game they could not win. This new state of affairs made it harder to articulate clear reasons why the new system was unfair. It was one thing to fight for the right to unionize, another to fight against rules that made an effective strike impossible.

Moreover, unions were tied to political parties in the late 1980's when public support and respect for these parties disappeared (see Chapter One). The collapse of the parties left the unions without interlocutors who could defend their interests within the political system against Fujimori and his technocrats. Thus the unions were discredited by their association with the parties, weakened internally by party rivalries, and left unrepresented in the formal political arena by the defenestration of their political parties.

In the aftermath of Fujimori's autogolpe, the link between union leaders 
and political parties broke down as union leaders became alienated from their former political sponsors. The leadership of the CTP dumped APRA, while the leadership of CATP withdrew from active participation in the PPC. Within the CGTP, some leaders remained loyal to the IU, while others ended up supporting Perez de Cuellar and the UPP (the UPP was the broad democratic front party formed to resist Fujimori in the 1995 elections).

By the end of Fujimori's first term, union leaders felt that the leadership of the parties no longer represented workers' interests. They thus preferred to participate in politics as independent candidates representing their own fledgling political parties, rather than supporting any established party. ${ }^{23}$ However, none of these attempts by labour leaders to form new parties created a mass political party with appreciable levels of public support. When labour abandoned the old parties, it was incapable of creating a new political formation that would represent its interests.

However, the collapse of the political power of labour was due to more than just its internal political failure. Labour's political credibility was also dismantled by economic catastrophe. The economic crisis destroyed the legitimacy of state-led industrialization as an economic and political project, as the model succumbed to successively worse crises from Velasquez to its final crisis under García. Yet the growth and dynamism of the labour movement

23

Alfredo Silva, "Una Representacion Legitima," en Cuadernos Laborales 105 (October 1994), 28. 
depended upon the extension of capitalist labour relations. As new workers were absorbed into industry, unions would absorb them too. ${ }^{24}$ But instead, throughout the 1980's, industrial employment declined. As Carmen Rosa Balbi, a Peruvian sociologist, commented,

For the existence of a dynamic labour movement it is necessary that wage labour can reproduce itself, that is to say that the principal form of the absorption of labour takes the form of the extension of capitalist wage labour relations. At the end of the seventies, the Peruvian development model, basically import substitution industrialization was the major means by which wage labour could be incorporated into production, and also as their intermediaries the labour movement. But ISI entered into a series of crises, each worse than the last. ${ }^{25}$

As the proportion of the labour force in formal wage labour shrank rather than increased, unions represented a dying sector, not a growing one. Yet their analysis said that industrial workers were the wave of the future, that their duty was to organize and lead workers in the vanguard of la lucha, the struggle. As the clasista strategy yielded fewer and fewer tangible benefits and victories for workers, workers drifted away from the labour movement towards individual efforts to improve their lot. ${ }^{26}$

As the formal economy imploded, Peruvians turned to extended kinship ties for survival, and away from participation in clasista organisations like unions

25

Carmen Rosa Balbi, "Sindicalismo y flexibilizacion del mercado de trabajo en el Peru," Debates en Sociologia, no. 19 (1994), 98. Translation by author.

${ }^{26}$ Parodi, 142. 
and political parties. ${ }^{27}$ With the collapse in the economy, unions did not offer protection for workers, they only threatened the existence of employment.

Note that this supports one of the central theses of this thesis, that labour unions were a manifestation of a particular order defined by the strategy of stateled industrialization and its particular form of social relations of production. In other words, state-led industrialization with its mass production facilities had the large workforces available to be organised into mass unions. Union contracts within this formation appeared as only another method of labour control. Codified union contracts spelled out the obligations of workers and management and hence provided a regularized system for managing conflict. Unions were therefore part of the order of state-led industrialization, and, when it failed, unions, too, became outmoded.

Under post-Fordist relations of production, work was dispersed as production was divided into global production chains of small subcontractors. This new style of production required an extremely flexible labour force that would move in and out of enterprises as contracts demanded. Discipline was invoked by the threat of global competition, a threat which compressed wages. But this new ferocious competition required the dissolution of unions and labour rights to create the flexible mobile workforce required by this new relation of production.

What is the relationship then between post-Fordism and neoliberalism?

\footnotetext{
${ }^{27}$ Sanborn and Panfichi, 47.
} 
On the one hand, neoliberalism as an ideology celebrates the values of competition and individualism which validates the needs of post-Fordist relations of production. On the other hand, neoliberal policies create the competitive global marketplace that can absorb post-Fordist production by focussing income and hence consumption into an international consumer class. From the perspective of the labour market, neoliberal policy created the atomized and flexible workforce required for post-Fordist relations of production. Thus postFordist relations of production exist happily within a neoliberal order.

Yet the transition to new production methods eroded the social context of the labour movement. The new dominant form of production was the microempresa, the small workplace of under ten workers, that used flexible production runs and sophisticated technology with computers that allow the geographic dispersal of work. ${ }^{28}$

This change was also a change in the social relations of production, which required the dissolution of unions. These new methods required an end to the structural obstacles of the union contract, with its seniority rights and rigid job classifications that prevented flexibility in the workplace. The new production methods created an incentive for business to attack the legitimacy of unions and dissolve systems of control that used formal agreements and grievance procedures with unions to regularize labour control..$^{29}$

\footnotetext{
${ }^{28}$ Sulmont, 230.

29
}

Sulmont, 231. For the point that unions help business formalize, regularize and 
They also required an end to the hostility and confrontation of the clasista unions. Employers instead sought a new relationship with workers which relied on workers devoting their creativity and initiative to the business. However, this new relationship with workers also required a shift in identity and loyalty from fellow workers to the interests of the employer and the business. ${ }^{30}$ Thus the new forms of production required a new social relations of production that eliminated the old union-management relationship.

Loyalty to the union movement was not only undermined by a change in the methods of management control, it was also undermined by the geographic dispersal of post-Fordist flexible production. According to Marx, it is the geographic centralization of the proletariat in the workplace, in comparison to the peasantry, that enabled the proletariat to develop a class consciousness, and class-based organizations like the labour movement. ${ }^{31}$ In The Eighteenth Brumaire of Louis Napoleon, Marx argued that the peasants because of their social, economic and physical isolation from each other, could not form a

hence control labour see Richard Edwards, Contested Terrain (United States of America: Basic Books, 1979).

30

Sulmont, 231. While it has always been the desire of employers to have loyal workers, this becomes crucial in post -Fordist workplaces where decision-making power has been devolved to individual workers. On an assembly line, discipline can be maintained by the speed of the line. But in a computerized production line, initiative is required to keep the machinery working. Alienation and clock watching can be fatal to the business.

31

See Karl Marx, Selected Writings, ed. David McLellan (New York: Oxford University Press, 1977), 317-318. 
cohesive class. The logical deduction from this is that because the proletariat were spatially concentrated in urban areas and their workplaces were organised under an hierarchical division of labour, they were able to develop class organisations like unions. The proletariat's organisations (unions) then articulated a class consciousness which formed the basis of a counterhegemonic order.

Those subaltern classes that were left unorganized were vulnerable to the appeal of a dictator. Like Louis Napoleon, Fujimori derived his support from the very sectors that were incapable of organising themselves because of their dispersal: the indio rural communities and the informal sector. Post-Fordist production only increased the relative size of these marginalized and dispersed groups.

The new production methods replaced the old Fordist plant with its thousands of workers with decentralized production and even decentred production across national boundaries. This dispersal fragmented the working class and at the same time reduced its capacity to organise class struggle. As Alberto Andrienzen, a Peruvian sociologist, explained: "It is very different to gather together and organise a thousand people when they are already together at work, but it is another case when one is in Chosica, another in Comas, and another in Villa El Salvador."32 Geographic dispersal disarticulated and dissolved

32

Alberto Andrianzen, "Desafíos del Movimiento Sindical Frente a la Problemática de la Calidad de Vida y Condiciones Laborales de Los Trabajadores" en Movimiento Sindical: Una propuesta para el mejormiento de la calidad de vida 
the bonds that had existed between workers and was formed in the mass production workshops of Fordism.

In Peru, post-Fordist flexibilization also meant the transfer of workers from large scale factories into small scale workshops in the informal economy. Because a change to smaller production facilities also usually entailed a transfer beyond the legal restrictions and regulations of the formal sector, this dispersal also entailed the marginalization and informalization of workers. Employment in this sector was precarious and transitory, and thus, workers failed to develop long term relationships based on work identity and hence a class identity.

The scale of the new forms of production undermined the development of solidarity as well. Fordist production alienated workers by the lack of contact between proletariat and bourgeoisie. Yet the small scale of post-Fordist workshops ensured contact and connections between workers and management. Thus, the scale of work undermined the formation of workers' solidarity by promoting allegiance to the workplace.

The internal contradictions of the relationship between the labour movement and their political representatives also made labour fatally vulnerable to neoliberal reforms. The unions were extensions of political parties, so at the moment when those parties imploded, unions were left without representation.

(Lima: Plades, 1993), 108. Translation by the author. While Andrianzen referred only to different widely dispersed poor barrios in Lima, the poor condition of Lima's transportation network, would make a trip from Comas to Villa El Salvador a three or four hour journey whose expense would be beyond the pocketbook of most obreros. Thus Andrienzen was making the point that workers at these dispersed locations would have no way to contact each other. 
The tactics of the labour movement were focussed on the state, yet the antipolitics of Fujimori along with the disdain of neoliberal technocrats for intervention (see Chapter Three) meant that paros only reinforced their determination to impose reform. Thus, the unions were tied to a set of contradictions and failures in tactics, ideas and political parties that left them bereft of support at the very moment when neoliberal technocrats threatened to dismantle all labour rights.

But while these contradictions were dangerous, what was worse was the internal disarticulation of labour, the dissolution of class loyalty to the movement and the inability of that movement to express an alternative to neoliberalism. The combination of these factors led to a situation where the political allies of labour were disgraced, the movement was divided by petty factionalism, and the leadership defended demands based on the failed dreams of state-led industrialization. The industrial working class which formed the social base for unions disappeared in an economic crisis for which the unions could offer no solutions. It was as though each of the internal weaknesses of labour had become critical at the very moment that the general crisis destroyed the external pillars of support that protected labour's interests within the state.

\section{The Internal disunity of Labour:}

The crisis of representation within the Working Class

In the late 1980's and early 1990 's a series of divisions arose that led to a 
crisis of representation within labour where in Marx's phrase: "the representatives and the represented faced one another in estrangement and no longer understood each other. ${ }^{\text {"33 }}$ Like the political parties, a crisis of representation had shattered the political strength of labour by undermining and eliminating a set of linkages between the leadership of the labour movement, the rank and file membership, the unorganized working class and the general public. These divisions led to a situation where the leadership of the labour movement tried to defend policies and rights their members did not support or desire, while unorganised workers loathed the unions and unionized workers, and the general public regarded unions as a problem, not a solution. Without the support of their own members and the broader working class, the political power of labour vanished.

The division between the leadership of the labour movement and its rank and file members reflected their differing political beliefs. Rank and file members supported a communist leadership without supporting communism. They believed communists could be trusted to defend their interests in negotiations with management and the government, in contrast to less clasista leaders who might sell them out. ${ }^{34}$ But this support for radical leaders was primarily personal not political - their respect derived from the personal integrity of clasista leaders and not from their political allegiance to the political line of union leaders. The

\footnotetext{
${ }^{33}$ Marx, 305.

${ }^{34}$ Interview with Carmen Rosa Balbi, Peruvian labour sociologist, August 1997.
} 
membership supported the hard line of the clasista leaders because they expected that intransigence would lead to better contracts.

The union leadership and the mass membership had developed this implicit political bargain under the military government and its democratic successor Belaúnde. According to a study conducted by Jorge Parodi in the metallurgical industry, this pragmatic attitude towards the union leadership derived from relations of dependence formed in the 1970s. The left parties ${ }^{35}$ provided skills and resources to the unions when they were formed. A strategy of politicizing all disputes into la lucha or the struggle brought real benefits to workers in terms of job security, working conditions and higher wages. ${ }^{36}$ In return for these benefits, the workers offered their personal loyalty to union leaders under the military government. ${ }^{37}$ Workers accepted demands for participation in political demonstrations as a personal display of loyalty and gratitude to their leaders. Furthermore members accepted discipline and demands for attendance, out of the fear that they would be expelled and lose the protection of the union. One union leader, Feliciano Pacheco described the feelings this way: "At that time, to be expelled from the union was simply and

35

The unions were colonized by a broad variety of generally Marxist, radical political parties. The differences between the parties were mainly driven by faction and arcane political disputes. Since they were all generally members of the Izquerda Unida, the United Left, the most accurate description of these parties is a generic one: left.

\footnotetext{
${ }^{36}$ Parodi, 140.

${ }^{37}$ Parodi, 67-68.
} 
plainly to be in the hands of the company, and no one wanted to be kicked out of the union, no one. ${ }^{338}$ Yet at its heart, this obedience was based on a delegation of power to their leaders in return for benefits received, rather than a belief in "la lucha". ${ }^{39}$

By the early 1980s, the rhetoric and actions of unions had become even more hard-line when management tried to cut back benefits. A union newspaper pronounced that "our rights will not be mortgaged, they will be defended with blood. ${ }^{{ }^{40}}$ As time wore on, the increasingly violent rhetoric of the union only alienated workers, as it became clear that, under García, the economy was breaking down. Demands to defend jobs, benefits and wages as sacrosanct were clearly out of touch with reality when the economy had collapsed. When union leaders could no longer deliver benefits, they lost the loyalty of the membership, and claims to represent workers politically were revealed as false.

The political division between the clasista labour leadership and the rank and file, became evident in their reactions to the economic crisis under Garcia and the imposition of neoliberal reforms under Fujimori. The leadership resisted Fujimori's reforms and attempted to defend labour rights and class interests by calling paros. But the rank and file had become disillusioned with the tactic of

\footnotetext{
${ }^{38}$ Parodi, 67-68.

${ }^{39}$ Parodi, 140.

${ }^{40}$ Parodi, 94.
} 
paros as they failed to defend effectively their interests and incomes. They also could not personally afford strikes. When hyperinflation and hyper-recession threatened the existence of all businesses and everyone's financial viability, a call for a paro to defend the interests of those lucky enough to be employed made no sense to workers. The government lacked the power to protect anyone against hyperinflation, and hence a political strike was pointless. Workers ignored the call for paros in the belief that a paro would only result in the permanent closure of their workplace. The fear that workers expressed in interviews was not of exploitation, but of unemployment. ${ }^{41}$ Indeed by the time Fujimori entered office, strikes actually helped business. Demand had collapsed and thus a strike merely allowed businesses to reduce production without paying workers severance. What workers hoped for was a decent severance package so they could establish their own business in the informal sector, rather than the life long job security unions fought to defend..$^{42}$ Moreover, the economic model of state-led industrialization the unions so valiantly defended was seen by their members as the cause of the crisis. ${ }^{43}$ Thus while union leaders articulated a radical clasista politics of confrontation against exploitation, their members wanted less confrontation and understood that the economy had to change.

41

Balbi, "Sindicalismo y flexibilizacion del mercado de trabajo en el Peru.", 100. Balbi conducted a wide ranging series of interviews with workers for her study.

${ }^{42}$ Parodi, 142.

${ }^{43}$ Balbi, "Sindicalismo y Flexibilización del Mercado de Trabajo en el Perú," 100. 
The result of this crisis of representation within labour was a labour movement unable to defend itself. When rights of unions were stripped after the autogolpe, over half of wage workers were uninterested in their defence, nor were they interested in what unions had to say. ${ }^{44}$ The CGTP called a paro in protest over the gutting of labour rights which had no support and only proved their political impotence. Since labour leaders called this paro during a Sendero offensive, not only did they prove that no one supported them, they also demonstrated just how out of touch they were.

Non-unionized workers in the same workplace as union members also did not feel solidarity with unions. During the military government of Velasco, all permanent workers were granted lifetime job tenure and could not be terminated without government permission. The decision to dismiss had to be legally justified and hence labour discipline was transferred to the state. The loss of the power to invoke labour discipline and the almost impossibly high cost of reducing the work force for business reasons, in turn, created a barrier to new business investment. These labour stability laws were viewed by businessmen as "one of the principal causes of problems within their businesses". ${ }^{45}$

Under García, to increase employment, employers were given the right to

\footnotetext{
${ }^{44}$ Balbi,“"Sindicalismo y Flexibilización del Mercado de Trabajo en el Perú,” 108. 45

Giovanna Larco Drouilly and Carlos Meja Alvites, "Con Los Ojos Bien Abiertos...Reestructuacion Empresarial y Sindicalismo en Los 90." en Los Desafios Sindicales de la Reestructuracion Empresarial (Lima: Plades, 1996), 91. Translation by author.
} 
hire temporary workers without being subject to the laws of labour stability. This program created a new class of younger, temporary workers. The proportion of these temporary and probationary workers grew until they formed half the blue collar workforce. ${ }^{46}$ Yet these temporary workers were prohibited by law from joining unions, and unions were prohibited from representing them in contract negotiations.

The attitudes of this new class of temporary workers to unions proved to be crucial in any struggle with the state over labour rights. If these workers had identified themselves with unionized labour, then together they would have formed a powerful block. However, these temporary workers viewed unions as a hostile force that worked against their interests: $40 \%$ of temporary workers thought that unions only protected the interests of established workers, while only $16 \%$ thought unions protected workers from abuse by management and 30 $\%$ thought that unions defended workers' interests. ${ }^{47}$ The union movement had lost the allegiance and respect of those with only precarious employment.

Underlying the erosion of the legitimacy of the labour movement was a generational and an attitudinal shift in the working class. On the generational front, union members generally ranged from 35 to 55 , and temporary workers ranged from 18 to 24 years of age. Temporary workers thought that their personal way forward lay in gaining better technical qualifications for which they

\footnotetext{
${ }^{46}$ Balbi, "Politics and Trade Unions in Peru," 136-137.

${ }^{47}$ Balbi,"Sindicalismo y Flexibilización del Mercado de Trabajo en el Perú," 111.
} 
would be better paid and would lead to more interesting work. They were not interested in the broad solidarity goals of the previous generation - achieving permanent job stability and solidarity in wages. They wanted to achieve based on their personal qualifications and abilities. Yet to the unions, a worker who accepted the need for qualification was a sell out to the employers and a scab. A worker who set himself apart from fellow workers on the basis of his qualifications broke solidarity with his comrades and became a tool of management. Thus, an increase in technical proficiency undermined union solidarity. ${ }^{48}$

The result of this crisis in union legitimacy was that $80 \%$ of temporary workers had never participated in any of the mobilizations, demonstrations, strikes or paros conducted by labour. ${ }^{49}$ Hence the vast majority of younger workers had never been socialized in the mass rituals of union solidarity.

Not only had unions forfeited the loyalty of the next generation of workers, they had also lost the general support of the broader public. By the time Fujimori came to power, the tide of public opinion had turned against the labour unions. What union leaders attempted to defend as a principle was regarded as the source of Peru's problems. One strategic area that the unions tried to defend against was the downsizing of the state apparatus through privatization. Under the previous model of state-led industrialization, the state was supposed to

\footnotetext{
${ }^{48}$ Balbi,"Sindicalismo y Flexibilización del Mercado de Trabajo en el Perú," 112.

${ }^{49}$ Balbi,"Sindicalismo y Flexibilización del Mercado de Trabajo en el Perú," 111.
} 
funnel capital into strategic sectors by investing in state-owned enterprises in the industrial sector. These state-owned enterprises employed the backbone of membership in the labour movement. But by the time Fujimori took office, the public held nothing but contempt for these enterprises for they had become a byword for inefficiency and corruption. Previous administrations had doled out jobs in these enterprises as rewards for their followers even as they delivered poor services. A left wing academic Carlos Amat y Leon commented;

We have a state that for the last hundred years, has served noone. There is a consensus today in Peruvian society, that the state has worked for none, not for governments of the left, not for governments of the right. Everyone rejects the state for its uselessness, for its bureaucracy, for its corruption, for its inefficiency, and ineffectiveness. It works for no-one. ${ }^{50}$

In this situation, union protests against privatization fell on deaf ears.

Bureaucrats were regarded by the public as corrupt beneficiaries of political patronage who were paid three to four times private sector wages with full indexation at a time of hyperinflation. ${ }^{51}$ A month long strike by the state workers' union against Fujimori in 1991 collapsed when it had no public support.

Yet, public support for unions was crucially important in defending their

50

Carlos Amat y Leon, Situación Nacional en La Última Decada: Desafíos del Peru en los Años 90," en Movimiento Sindical: Una Propuesta para el mejoramiento de la calidad de vida (Lima: Plades, 1993), 22. It should be noted that while Amat y Leon served briefly under Fujimori, he had also run as a vice presidential candidate for IU. When a left wing academic condemns the state as the source of Peru's problems, who else would support state ownership and control over industry and the state led economic model?

${ }^{51}$ Balbi, "Sindicalismo y Flexibilización del Mercado de Trabajo en el Perú," 105. 
rights against attack by the state. A generalized belief in the right to organize was the best protection for unions. Public support for the legitimacy of the labour movement in principle, had to also be matched with the recognition that labour leaders were its legitimate interlocutors. This did not mean that the public supported what labour leaders had to say, only that they agreed that union leaders legitimately spoke on behalf of their organisations and accurately represented the interests of their members.

When labour leaders lost even this basic level of credibility, then they lost their utility as political interlocutors for the state. There was no point in negotiating with labour leaders over reforms when they represented no one.

The political situation for the labour movement in Peru in 1990 was dire. The labour movement as a whole suffered from a crisis in representation as critical as that of the political parties. The implosion of their political allies left the labour movement without political representatives that could defend their interests. The labour movement suffered from an equivalent loss of legitimacy with the general public until their defence of union rights was viewed as the complaints of the corrupt. Non-affiliated fellow workers regarded unions as a barrier to their hopes and aspirations, instead of a solution. Even the rank and file membership were unrepresented by the leadership. Disunited, discredited, disorganised and disconnected, the labour movement was unable to defend itself politically against neoliberal reforms that gutted labour rights.

But the sad irony about the situation of labour unions was that their political weakness stemmed largely from their own internal contradictions, rather 
than from a bourgeoisie determined to annihilate them. The very order, state-led industrialization, within which the union movement had been born, was dying. The industrial sector was shrinking and not growing. Their traditional tactics threatened their own members more than their employers. Even the workplace which had been the site for the articulation of a working class consciousness, was being dispersed and atomized. All the labour movements strengths became its weaknesses. The totality of the crisis sparked a crisis of faith, a crisis in ideology as the clasista rhetoric rang hollow and unions failed to offer a believable alternative. But at the moment when the internal contradictions of the labour movement had left it vulnerable, a threat that was external to the unions decimated them: Sendero and the security crisis.

\section{Conjunctural Factors: Sendero and the Security Crisis}

As we have seen Sendero's war against the state undermined the economy and the legitimacy of the political elite, dislocated the rural population into the cities and generally increased the sense of structural crisis in Peru (see Chapter One). By also targeting the union's leadership, Sendero weakened an already vulnerable labour movement.

Unlike other dirty wars in Latin America, for example in Chile and Argentina, the major threat to the lives of labour leaders came from Sendero Luminoso rather than from the death squads of the Peruvian intelligence service, 
the SIN (Servicio Inteligencia Nacional. ${ }^{52}$ Thus, unlike elsewhere, Peru's labour leaders were not eliminated in order to secure neoliberal economic reforms.

Sendero's campaign against labour leaders was part of its overall strategy to infiltrate and colonize civil society, while it eliminated those leaders and organisations beyond its control. To Sendero, labour leaders who were not Senderistas were enemies and hence legitimate targets of their annihilation squads. In May 1989, El Diario, the Sendero newspaper, concluded that it was necessary "to eliminate the revisionist, sell out leadership" of the unions for not supporting the people's war. From January to May 1989, Sendero's annihilation squads assassinated over 50 labour leaders. ${ }^{53}$ Sendero's attack on labour was particularly damaging because its targets included grassroots labour activists as well as the peak leadership ${ }^{54}$ At a time when the economic crisis had already squeezed union membership, Sendero made union activism suicidal. Thus, Sendero both disrupted the natural cycle of recruitment and decimated the human capital of labour by murdering experienced activists.

52

Coyuntura Laboral, "Violencia contra Los Trabajadores," (January 1993), 13. Coyuntura was a publication of $A D E C-A T C$, a Peruvian labour think tank and hence its assessment can be regarded as reliable and not simply government propaganda.

${ }^{53}$ Poole and Renique, 94.

54

Unions in Peru were more dependent on the voluntary efforts of its members than other organisations. At the level of the local most of the work was performed by members from shop stewards to organizing strike activities. Thus unions were dependent on the experience of grassroots activists, experience that generated expertise and the human capital of the labour movement. 
In addition, Sendero attempted to appropriate the discourse of labour. Many of the labour movement's actions were symbolic and almost ceremonial in nature, from the drama of the strike and the paro to confrontations and negotiations with management and mass demonstrations. These actions embodied a series of messages and meanings - from the invocation of collective solidarity to the rebellion of workers against the alienation of labour by capitalism to their reclaiming their own power and autonomy. The strike, in this sense, became a reification of the ideals of collective solidarity and workers' power.

Sendero turned acts of solidarity into anomie. Even though Sendero had little or no influence or involvement in events and organisations, through its newspaper El Diario, Sendero constantly portrayed all labour conflicts as more violent than they were. This exaggeration of violence allowed Sendero to appropriate all union action as part of the struggle of the people's war. In the few labour unions Sendero had successfully infiltrated, Sendero cadres promoted confrontation by refusing to settle strikes, making unfeasible demands and generally subverting union activity to promote chaos and terror. ${ }^{55}$ Sendero's broader strategy was to demonstrate that the state was unwilling to respond to the people's needs and that peaceful change was impossible. If only violence was realistic, only Sendero offered hope for el pueblo. ${ }^{56}$

\footnotetext{
${ }^{55}$ Poole and Renique, 94.

56

Jo-Marie Burt, "Shining Path and the Decisive Battle in Lima's Barridas: The case of the Villa El Salvador," in Shining and Other Paths, Steve J. Stern (Durham: Duke University Press, 1998), 283.
} 
These tactics alienated workers from the authorship of their own struggles, and also delegitimated the entire ideological discourse of the labour movement. The rich symbolic discourse of clasismo, of exploitation and resistance, of struggle and strikes became equated with the violence and terror of Sendero as strikes became "armed strikes" enforced by annihilation squads.

However, in addition to the decimation directly inflicted by Sendero, the security crisis provided camouflage for the security forces who also targeted labour leaders. Security forces detained activists who would disappear for a few days, thus contributing to the atmosphere of terror and insecurity. During the autogolpe, the military briefly arrested labour leaders, and occupied the headquarters of the CGTP, CTP, Federacion Construction Civil (the construction workers union) and the SUTEP (the teachers union). ${ }^{57}$ But, as noted above, unlike the other dirty wars in Latin America, there was no systematic attempt by the military to eradicate labour leaders.

However, there was one prominent case where the security forces did assassinate a prominent labour leader: Pedro Huilca Tecse. Pedro Huilca was the leader of the CGTP, the most prominent and powerful labour confederation in Peru. Ironically, Pedro Huilca was a pro-democracy labour leader who had called for the democratization of his own labour federation, an acceptance of pluralism within the movement and an end to petty factionalism. Originally, there had been resistance to his election as the secretary-general because he was not

${ }^{57}$ Coyuntura Laboral, "Violencia contra los trabajadores," (January 1993), 13. 
a supporter of APRA and Alan García. ${ }^{58}$ Instead, he called for the integration of other groups into the labour movement, like the vaso de leche (the Glass of Milk food cooperatives) and the ambulantes to form a broadly based coalition to defend democracy from Fujimori. ${ }^{59}$ Huilca was an eloquent exponent of the connection between defending democracy and protecting workers. He believed that the paramount mission of the labour movement was to defend democracy. Because he proposed a broad coalition between labour and other sectors for democracy and against Fujimori, Huilca became a threat to the regime. In the words of one commentator, he was .... "a stone in the shoe of Fujimori because of his threat to realize strikes and paros if the government tried to disband the labour movement." 10

Huilca was assassinated in December 1992 by the Grupo Colina, a secret death squad that was part of the intelligence service SIN. In 1997, Clemente Arayo, a former member of SIN and Colina, confessed to the assassination. ${ }^{61}$ At the time, however, Huilca's murder was attributed to Sendero, who had

58

The head of the CGTP was a key political position for a populist left government, and thus APRA tried to control the appointment.

59

Pedro Ortiz," Guardia obrera y popular luchar contra terrorismo y la guerra sucia," from an interview with Pedro Huillca in La Republica, (April 1, 1992), 3-4. The title of the article translates as "The workers guard and the popular struggle against terrorism and the dirty war" an apt description of the dangerous position of labour caught between Sendero and the military.

${ }^{60}$ Caretas, "Viejos Conocidos," 38.

${ }^{61}$ La Republica, internet version, December 16, 1997. 
threatened him as an "enemy and traitor to his class" for successfully defending his original union against them.$^{62}$ Sendero took credit for the assassination in EI Diario, because Huilca was a "barrier to the revolution". ${ }^{63}$ Thus the death of Huilca exemplifies not only how labour was targeted by both sides in the dirty war, but also how the state used Sendero to hide its own crimes.

The death of Huilca also encapsulated the cost of the security crisis for labour. With the death of Huilca, Peru lost an independent voice for labour, one that could have rearticulated a vision of a new democratic labour movement. While no one person was Peruvian labour's only chance, the murder of this democratic charismatic leader prevented an effective rearticulation of labour. The conjunctural threat of the security crisis stripped labour of the resources of legitimacy and of leadership precisely at the moment when the internal contradictions of the movement overwhelmed it.

Labour was not only under physical threat from Sendero and the SIN, it was also politically isolated and vulnerable. While Sendero weakened the labour movement, this was not a sufficient cause that could explain how it was politically possible for neoliberal technocrats to dismantle labour rights or labour's continuing weakness. If the only political problem labour had faced was the literal decimation of leadership cadre, then once the security threat receded in the late 1990's, labour's leadership could have been naturally replenished from within.

\footnotetext{
${ }^{62} \mathrm{Si}$, "Quien lo mato," no. 4 (December 21-27, 1992), 10.

${ }^{63}$ Coyuntura Laboral, "Violencia contra los trabajadores," 13.
} 
Even though the unions were caught between Sendero and $S I N$, once the economic crisis had eased, they should have been able to regenerate and rearticulate themselves to work within the neoliberal regime. The reason they did not was that neoliberal reforms effectively prevented their resurgence. Just how biassed these reforms were, is the subject of the next section.

\section{The Rigged Game: Neoliberal Labour Market Reforms}

The labour market reforms under Fujimori went beyond mere temporary measures to stabilize the economy. They marked a profound transition in the relationship between the Peruvian state, the regime of accumulation and the labour movement. Labour market reforms not only involved dismantling hard won victories for labour in the name of improving labour market flexibility, but also involved changes that permanently undermined union power. The new labour code meant that if unions played within the rules, workers would always lose. As we have seen, the traditional strategy for unions in Peru had been to politicize the struggle and, through political intervention, win victories . Yet in Fujimori's government, the political bias had shifted from protecting workers to enforcing the interests of capital.

The overarching concept that justified the gutting of labour rights was flexibilization. The argument was that the labour market was too rigid and did not allow labour to be redeployed efficiently within the economy. Life long job security prevented businesses from shedding unneeded surplus labour. Rigid job 
descriptions prevented the adoption of new technologies and the effective redeployment of workers within the workplace. These labour market rigidities also inflated wages which prevented new investments. According to neoliberal theory, the labour market had to be freed from these rigidities in order to facilitate the natural clearing of the labour market. In practise, flexibiilzation meant enabling business to shed workers more easily and compress wages by dismantling the power of unions to resist without, however, increasing employment.

The labour market reforms under Fujimori marked a fundamental change in the role of the state in labour relations and class relations. Under the constitution of 1979 , the state was constitutionally charged with the responsibility of protecting worker's rights vis -á -vis capital. But after the autogolpe, labour rights were eliminated by decree in ways that contravened the suspended constitution. The autogolpe thus enabled Fujimori to act as the dictator who resolved the structural impasse by fiat and created a new state that articulated a new social relations of production within a new labour code. Thus it was after the autogolpe that the most far-reaching changes to the labour code were imposed and the game of labour relations was most heavily skewed against unions. More fundamentally Decreto Ley 25593 , the basic labour law Fujimori imposed by decree in July 1992, changed the underlying philosophy of the labour ministry from protecting workers to improving business conditions. Interventions in labour relations were to be made now in the name of "benefiting increased 
competitiveness in support of business for the market." ${ }^{164}$

The rhetoric of the state changed in ways that matched the shift from state-led industrialization to neoliberalism. Market competition had become the predominant value, ahead of social justice or fairness. The primary purpose of the state has become enhancing Peruvian enterprises' competitiveness, not securing the protection of its citizens.

The state's change to a bias in favour of business was clear in the terms and conditions under which the state would intervene in labour disputes. The executive branch could intervene in any case "where the strike was deemed to have gone on too long and threatened a business or a productive sector or there was violence." ${ }^{65}$ Once article 68 was invoked, the Minister of Labour was empowered to order employees back to work, though without prejudice to negotiations. In other words, the Minister of Labour could end a strike at will if it threatened a business without either imposing a contract or arbitration. Lengthy strikes that had led in the past to breakthroughs for the labour movement were now banned. Previously strikes had put pressure on businesses to settle by threatening them with bankruptcy or with political intervention by the state to impose peace. But now business could use a strike to demand concessions from workers secure in the knowledge that, if the strike caused economic damage, the 64

Amalia Mendoza Arroyo, "Obitrario para el Dercho Laboral" , Cuadernos Laboral 84 December 1992. p 19. The title of the article translates as Obituary for Labour Rights.

${ }^{65} \mathrm{DL}$ 25593. Article 68. 
state would intervene and impose a settlement to their benefit.

The new rules not only banned strategic strikes; in the case of first contracts, they explicitly prevented unions from making gains for their new members. First contracts are usually crucial for unions to prove their worth to new members through gains in protection, power or wages. But under the new rules, when business and the union failed to reach a settlement during first contract negotiations, the contract was to be imposed at the previous standard of the employer. ${ }^{66}$ This meant that not only could a first contract not lead to a wage increase, but also that negotiations could not change relations of power within the workplace. The terms and conditions of work including job security, workplace safety, pay scales and scheduling would not be subject to negotiation, but effectively would still be subject to the discretion of the employer. Thus the new labour code pre-empted workers from gaining power against employers by organising a union since the employer would only have to stall negotiations and then have the state enforce previous power relations.

Even if workers had a contract, the new regulations enabled employers to alter its terms almost at will. If an employer wanted to change benefits, hours of work or suspend workers, then they could apply to the Autoridad Administria de Trabajo in a summary procedure to change the contract. ${ }^{67}$ If the AAT did not

66

David Palacios Lovaton, "El vínculo entre los niveles negociales y la autonomía colectiva en el Perú," Asesorial Laboral, April (1993), 10.

67“Los Poderes del Estado" Coyuntura Laboral, January (1993), 8. 
respond to the request within fifteen days, the request was presumed to have been accepted and would be automatically granted.$^{68}$ Under this procedure, the consent of either the union or its members were not required to change the terms of a contract nor could they defend contract rights before the AAT. Thus, the position of the state in labour relations changed from defending workers and enforcing contracts to one of eliminating the effectiveness of collective bargaining. Whatever gains unions might have won at the bargaining table, business could now circumvent the process by simply applying to the AAT. Contracts became unenforceable for unions and collective bargaining irrelevant.

While the state's administrative processes were explicitly pro-business, the new provisions also undercut the labour movement by restricting the scope of collective bargaining. Beyond higher wages, union contracts offer the possibility of increased security for workers by restricting the arbitrary power of the employer. It was the fear of abuse by their employer as much as higher wages that had originally attracted workers to unions in Peru in the 1970's. ${ }^{69}$ When union contracts set standard wages for job categories, employers could not use favouritism to terrorize and discipline workers. Grievance procedures tempered the whims of employers.

The new provisions reinstated the power of the employer by restricting the scope of union activity and the subjects for collective bargaining. First, all

\footnotetext{
${ }^{68}$ Mendoza Arroyo, "Obitrario para el Derecho Laboral," 19.

${ }^{69}$ Parodi, 67.
} 
clauses in contracts that contained cost of living allowance or automatic inflation indexing were voided and future indexing was prohibited under Decreto Ley 757 and Decreto Ley $25541 .^{70}$ Workers could no longer protect themselves from hyperinflation through collective bargaining. Secondly, administrative acts or workplace disciplinary cases were no longer subject to arbitration, which meant, in effect, that employers had absolute authority and workers no means of collective defence. Thirdly, who was to be paid what was solely at the discretion of the employer, as their "inalienable prerogative". ${ }^{71}$ This meant that unions could not negotiate uniform pay scales based on time served, nor could they protect workers against discrimination in a society with the expression "cholo barato" or cheap indigenous labour. In Peru, one of the impetuses that created the labour movement was the favouritism and discrimination based on race and place of origin. $^{72}$

Fourthly, the new labour regime ended the progressive nature of union contracts, the expectation that each round of negotiations would result in new gains for workers. Past victories by workers were regarded as sacrosanct and each round of negotiations brought new benefits. But the new labour regime abolished progressive contracts, since all past contracts set no precedents and

\footnotetext{
${ }^{70}$ Mendoza Arroyo, "Las relaciones colectivas de trabajo del liberalismo," 16.

${ }^{71}$ Lovaton Palacios, 10.

72

Parodi, 107-108. Management used local thugs to enforce discipline on the shopfloor in the argolla system. This was replaced by union discipline.
} 
every clause in a contract was automatically reopened for negotiation. ${ }^{73}$

While from a neoliberal perspective, no precedent setting levels the playing field between business and labour, in practise, opening Peru to the vagaries of the international market, justified gutting benefits in the name of competitiveness. Thus the new labour regime undercut the labour movement through reducing the scope and subjects for negotiations through abolishing indexation, eliminating union protection for workers from arbitrary acts of management, making wage scales solely a management prerogative, and reversing contract negotiations from progressive to regressive for workers.

The new labour regime not only circumscribed the scope for negotiations it also restricted who could be represented by unions. Two criteria were established: first, a sector like the construction industry had to have over one hundred employees before it could be unionized or secondly, an individual enterprise had to have over twenty employees. This rule effectively prohibited the overwhelming majority of Peruvian workers from organizing since two thirds worked in workplaces with under ten employees, while $90 \%$ worked in businesses with under 20 employees. ${ }^{74}$ Hence this requirement not only prohibited most workers from joining a union, but also eliminated the strategic impact of unions on general wages and standards. The union movement was restricted to such a small segment of the workforce that union contracts no

\footnotetext{
${ }^{73}$ Mendoza Arroyo, "Las relacionnes colectivas de trabajo de liberalismo," 19. ${ }^{74}$ Prelle, "Los sindicatos y sus atribuciones," 3.
} 
longer set the standard for the general population. Instead those workers who could unionize were exceptional cases, a labour aristocracy of privileged workers, easily politically isolated as self-serving rent seekers by the bourgeoisie. Instead of being regarded as the vanguard of the proletariat, unionized workers were characterized as the "whinging" of parasitic classes. ${ }^{75}$

A second restriction was that all temporary workers and probationary workers could not join a union nor could the union represent them during contract negotiations. While under Garcia there had been a special program for temporary workers, under Fujimori these restrictions were made universal and permanent. The prohibition against organizing these new workers created a generational division between older and younger workers, and a class division between permanent and temporary workers. It also created competitive pressures within the workplace, with employers creating a cheap and permanently temporary workforce with no benefits and lower wages that threatened the jobs of the permanent workers.

A third restriction was that all unions had to be officially registered, when registration was permitted only at the discretion of the state. While official registration might not seem to be too onerous a burden, within the specific context of Fujimori's Peru, union registration was a threat, not a recognition by

75

While this may seem to be a bit strong, this language is in keeping with the rhetoric used by Fujimori's supporters. Pensioners who protested about the erosion of the value of their pensions were called chumechados or fat hogs by C90 Congressman Victor Joy Way. 
the state of the legitimacy of unions. The registration process required unions to behave themselves and not participate in "illegal" activities such as paros and wildcat strikes, the most effective tactics for the labour movement. Union locals also had to provide the state and employer with a record of properly run internal union business, including lists of union officers.

Within the new labour regime of Fujimori, to follow the rules was to invite defeat. To provide lists of names was to invite retribution for members. While government death squads were not an ever present threat, Fujimori's code had no protection for the financial security of grass roots labour activists. Anti-union employers could enforce blacklists, punish activists with loss of promotions, reduce work hours and stall negotiations with impunity. ${ }^{76}$ In a context of massive unemployment, the threat of blacklisting activists was a real threat.

By restricting unions to a small sector of the population, the state effectively eliminated unions as the strategic site around which workers could articulate their interests as a class. Only permanent workers in large companies could join a union, and those who did join, did so at their own peril. Hence, unions as worker organisations could not form the nucleus of working class counter-hegemonic civil society. Instead they represented an older aristocracy of labour.

But the new labour system not only prevented the labour movement from

76

Palacios, 5 . Only a small proportion of union officers were allowed protection against management attack, amounting to only 3 per 100 workers. 
organising and representing the broad working class, the system was also rigged against unions effectively defending their members against management. The new labour regime not only eliminated labour's tactics, it also blocked some of the sources of union power.

One source of union power was the closed shop, a form of contract that was expressly banned after the autogolpe. Article 3 of DL25593 on the surface used the rhetoric of neoliberalism to sound fair and unbiased:

Union membership is to be free and voluntary. Membership in a union will not be a condition of employment, nor will nonmembership or renouncing membership be an obligation, nor will unionization be prevented.

On the surface this article appears to make union membership a free individual choice, since no one can make membership either obligatory or prohibit workers from deciding to join a union. However, in practise, abolishing closed shops where union membership was mandatory weakened the labour movement by reducing membership dues to voluntary contributions. It also eliminated the power of unions to discipline members for breaking solidarity by crossing the picket line. Without the ability to maintain discipline through sanctions, the effectiveness and strength of strikes as a tactic was diminished. In the skilled trade sector, the elimination of closed shop job sites eliminated the construction trades.

Unions not only lost the capacity to enforce discipline within the rank and file, they also lost its most effective weapons: the paro, the wildcat strike and the slowdown. In the Peruvian context with mass unemployment and meagre wages, 
workers could not afford the loss of wages entailed in a normal strike against a single employer. As we have seen, the preferred tactic was to politicize labour disputes by calling paros and wildcat strikes to threaten social unrest and hence force the government to intervene and impose a favourable settlement for workers across the board. Now, if workers participated in either a wildcat or a paro, they could be fired or subject to sanctions by their employer. Work slowdowns, a tactic designed to put pressure on employers without forgoing wages was explicitly banned in Article 81 of DL25593.

The only legal tactic left to labour was the strike or a complete cessation of work.

However while the right to strike was still legal, it was limited within the new system in ways that made strikes almost impossible to call legally, ineffective if called, and suicidal as a tactic for the workers involved. In order to call a strike, the union had to hold a public strike vote and receive an absolute majority of all employees. However, the vote was rigged by the inclusion of all those who worked in the enterprise including those in positions of fiduciary trust or management and all those who were temporary and probationary workers. ${ }^{77} \mathrm{By}$ now, temporary workers composed a higher and higher proportion of the workforce; $45 \%$ of private sector employees were in precarious and temporary positions by $1989 .^{78}$ Within the blue collar sector, temporary and precarious

\footnotetext{
${ }^{77}$ Mendoza Arroyo, "Las Relaciones colectivas de trabajo del liberalismo," 32.

${ }^{78}$ Balbi, "Politics and Trade Unions," 137.
} 
employment was even more pronounced with $50 \%$ in precarious employment. Yet neither the temporary nor management workers could by law be members of a union, nor could they be represented by labour unions in negotiations. They thus formed an automatic vote bank against any strike. Even if, by some miracle, a union got a strike mandate, they had to give management five days warning that a strike was immanent. This provision enabled management to hire scabs ahead of an announced strike deadline and replace any workers who dared to strike. If a strike was called, after fifteen days, workers would be deemed to have voluntarily left their positions and hence could be replaced with temporary workers and they would have renounced their rights to any severance payments due to them. ${ }^{79}$ The loss of severance payments was not an idle threat, since the right to a decent severance package was the major demand of permanent workers in the face of economic restructuring under Fujimori. Thus if workers went on strike to demand a better severance package, management simply had to wait fifteen days to erase all severance.

The effectiveness of strikes was further undercut since business could designate certain workers as essential, that is essential to the running of the business not society as a whole. These essential workers were not permitted to go on strike. But even if the strike was effective by shutting down the business and the employer could not simply replace their workforce, employers could

79

Mendoza Arroyo, "Las Relaciones colectivas de trabajo del liberalismo," 32. This particular provision in the labour code was taken almost word for word from Pinochet's labour code. Interview with Peruvian technocrat. 
simply apply to the government to impose an end to the strike at the "standard of the employer" on the grounds that it threatened their business. Thus the labour movement lost the use of strikes as a tactic in its struggle with business. If workers walked out either they would lose their jobs when replaceable, or be sent back to work if they had an effect on their employer.

Not only were the rules governing strikes blatantly biased against unions, the system as a whole could be easily manipulated by business. The changes legalized blacklists of activists and restricted protection to a very select number of union officers. The private sector was thus able to purge itself of activist workers who could then be banned and hence excluded from a particular sector or even the entire formal economy. Thus, employers gained the ability to threaten the survival of their workers, and reforms created a situation whereby the private sector regained an absolute and arbitrary authority over their employees.

The new system could also be easily manipulated by employers to cheat their employees. The method by which employers manipulated the system was to stall using the labour board, the AAT. By challenging recognition before the board, employers could stall negotiations indefinitely. Business could also tie up union resources by pushing unions into arbitration and micro negotiations. This changed union activism into an elite process where union and business lawyers controlled the process, rather than the shopfloor grassroots activists setting the agenda.

One of the most common tactics by business was to push individual 
grievances into the labour board process and then use the paralysis of the state to avoid their responsibilities. From 1983-1993, it was estimated that one third of all businesses had avoided paying their share of their employees' social security taxes. There were no consequences for businesses of this large scale tax avoidance because of the inefficiency and paralysis of the labour courts. For example in 1993 in Lima only 1770 out of 4223 registered cases of businesses shirking their obligations were prosecuted and processed. ${ }^{80}$ The incompetence of the courts meant that employers could ignore their obligations to their employees, especially since judgements were not adjusted for inflation. The common business strategy was to stall until the employee ran out of money in cases of unfair dismissal. With hyper-inflation and hyper-recession, all the employer had to do was wait, since once the judgement was finally enforced, it would be worth little after inflation. ${ }^{81}$ An ineffective state protected the interests of capital because its inaction made moot rights granted to workers. In law, workers might have had the right to severance payments, but, in reality, without legal enforcement, they had none. Yet without the ability to resist mistreatment through strikes, workers lost the extra-legal political actions that enforced contracts and indeed the social contract.

Labour negotiations were thus rigged against unions by banning effective

80

Paul Sumar Gilt, "La Demanda de Justicia Laboral," Cuadernos Laborales 106 (November 1994), 12.

${ }^{81}$ Sumar Gilt, 13. 
union tactics, by prohibiting unions from representing specific classes of workers, and by legalizing management tactics that made strikes difficult to call and impossible to win. The changes to the labour code around job security enabled employers to lay off employees at will. Union activists could be blacklisted, employees could be let go due to reasons of business, contracts could be changed at will, and differential wage rates could be set at the employers' prerogative. Unions were not explicitly banned, but they were barred from effectively defending their members' interests.

By reducing the effectiveness of the labour movement, the Fujimori government paralysed resistance to its neoliberal economic model and eliminated a political enemy. Coincidently, a change in the social relations of production by reforms to labour markets effectively hamstrung political opposition by unions. But coincidence was less a coincidence than a self-reinforcing set of changes in ideology, the state and the economy. The next section will explore how changes in the state's system of labour relations, in turn facilitated changes in the relations of production.

\section{The Political and Economic effects of Changes to Labour Markets}

As we have seen, the effect of the change in labour relations was to paralyse labour as a site of resistance to the new neoliberal social formation. The gutting of the labour movement created structural changes to labour markets and transferred power to employers. The effect of destroying unions was to create a flexibilized workforce, one that could be hired and fired at will for 
wages employers were willing to pay. This flexible workforce in turn fit the new flexible production runs of post -Fordist production cycles with short production runs staffed by polyvalent and skilled workers. By effectively annihilating the power of labour, the new regime allowed business to squeeze labour costs and increase capital accumulation.

The effectiveness of these changes to labour relations in creating a flexible workforce can be demonstrated by changes to employment structures in two economic sectors: clothing manufacturing and mining. In the clothing sector, the advantage of the new forms of relations of production was quite clear. The older larger firms with antique equipment tended to be the ones that were unionized with permanent workforces. But the new firms with newer equipment and the most dynamism were those in the small business sector with no permanent workers. They survived contract to contract on exports. ${ }^{82}$ In these small businesses, workers had no rights to unionize because they were only temporary workers. Thus, unions were excluded from the most productive and dynamic part of this sector.

In the mining sector, changes to the labour code facilitated changes in the structure of production especially through the privatization of mining assets and then new investment by transnational corporations. Ultimately transnational corporations ended up controlling $52 \%$ of mining production in Peru, with their

82

Giovanna Larco, "Situacion del Movimiento Sindical Textil y Confecciones," en Movimiento Sindical: Una propuesta para el mejoramiento de la calidad de vida (Lima, Plades 1993), 88. 
profits guaranteed by agreements that froze taxes at drastically lowered levels. ${ }^{83}$ This privatization process was politically helped by the paralysis of a labour movement which had traditionally resisted foreign control. In addition, state owned enterprises were part of the old discredited economic model, so resistance to privatization was futile.

Changes in technology had created a situation where large capital investments would generate profits, but not necessarily benefit their host mining communities. New mining technologies facilitated a drastic reduction in jobs while simultaneously increasing output and productivity. From 1989-1993 23,000 permanent workers and 10,000 temporary workers lost their jobs in the mining sector $^{84}$ In one mine Morococha, the number of jobs dropped from 850 to 200 permanent jobs with 250 temporary workers while its output and productivity increased. ${ }^{85}$ The ministry of Mines predicted that average output per worker would triple from $\$ 50,000$ per worker to $\$ 150,000 .^{86}$

Yet while productivity improved, the lot of workers declined as the power relationship shifted. In the mining sector in the past, mining companies had provided public services to mining communities as part of their costs. But after

83

Portugal Mendoza, "La Reestrucuración y Privatización de la Minera" en Los Desafíos Sindicales de la Reestructuracion Empresarial (Lima: Plades, 1996), ff $2,112$.

${ }^{84}$ Portugal Mendoza, 109.

${ }^{85}$ Portugal Mendoza, 113.

${ }^{86}$ Portugal Mendoza, 119. 
privatization, the responsibility for services was shed by companies. For example, in the case of Centromin, over 15 hospital and health centres were transferred to the state, along with hydro and water ${ }^{87}$ For the workers themselves, their remuneration changed as DL25593 allowed mining companies to roll back benefits and perquisites gained by unions over decades. Indirect costs beyond wages were eliminated. Companies no longer had to provide boots, clothing and equipment to their workers, and other guaranteed bonuses were slashed.

The structure of employment changed with regularized permanent work being replaced by individual contracts and temporary workers. The change to temporary contracts allowed mining companies to slash labour costs even though investment increased productivity. For example, at Centromin, permanent workers were paid 29 soles while those on probation were paid 12 to 20 soles. $^{88}$ Temporary workers not only had a lower base salary, but the employer also escaped paying benefits. At the same time, the threat of turning permanent employment into precarious employment disciplined permanent employees.

The privatization of Peru's mining sector not only changed the social relations of production, it also changed Peru's role within the globalized production process. In the copper industry, for example, the new transnational corporations focussed on the production of copper concentrate instead of refined

\footnotetext{
${ }^{87}$ Portugal Mendoza, 117.

${ }^{88}$ Portugal Mendoza, 116.
} 
copper which had been the practice of state owned enterprises. ${ }^{89}$ The copper concentrate was shipped to the United States for further smelting, thus capturing the higher end of the production cycle for the centre. Instead of it being possible for Peru's natural resources to be used to spark forward industrial development in the production of finished goods, they were used as cheap feedstock for the United States' own production. Thus globalization trapped Peru at the low end of the production cycle, at least until its resources ran out.

Within both the mining and clothing sectors, the changes to the labour code supported the transformation of Peru's economy into the new global neoliberal regime. The new precarious flexible labour force fitted within a system of production geared towards the export market. In order to guarantee cheap labour, this new system required a compliant labour movement whose paralysis was maintained by a biased labour relations system.

The anti-union system was in turn guaranteed by a Caesarist dictatorship. The advantage of a dictatorship for this system, was that it was insulated from democratic pressure by workers for changes to the labour code. This neoliberal labour code in turn excluded the labour movement from rearticulating its political power by banning unions from translating their resources into the basis for a new political movement. Article 11 of the DI 25593 explicitly banned a labour unions from making donations to any political party. This meant that the unions could not use their organisational resources to found a new political party; nor could

\footnotetext{
${ }^{89}$ Portugal Mendoza, ff 2, 112.
} 
they support broader political movements by seconding union officials. Labour was cut off from politics at a time when labour market reforms gutted union power.

The effects of the labour market reforms did decimate the unions. From 1989 to 1994 , the percentage of private sector workers who were members of unions declined from $34 \%$ to $13 \% .{ }^{90}$ In the name of creating a flexible labour force that could adapt to globalization, Fujimori created a labour market without rights or security for workers, a labour market where unions could not protect their members.

\section{Conclusions: The Transition in the Social relations of Production in Peru}

The Peruvian case indicates that a transformation of this magnitude seems to require a Caesarist dictator who would overturn the ideas that provided the ethical framework which legitimated previous social relations, dissolve the old institutional structure that had enforced the old code, and create a new set of institutions to enforce a new type of social relations of production. Yet the elected dictatorship of Alberto Fujimori was also a result of an underlying Caesarist crisis, a crisis in the state, a crisis in ideology and a crisis in social relations of production. As we have seen, the crisis was also a reflection, for the most part, of the internal contradictions of the labour movement. In a situation where their own members ceased to believe, labour unions followed outdated

\footnotetext{
${ }^{90}$ John Crabtree, 163.
} 
strategies to defend a social contract for a bankrupt model for the economy based on state-led industrialization. But this was more than a simple development strategy. Once it was instituted, it created its own organisations like unions and industries, that formed part of a civil society which defined an order. When the order collapsed, it made sense that unions would implode as well.

However, the failure of the labour movement was also a precondition for the implementation of neoliberalism. The crisis of representation within the labour movement meant that union leaders could not lead an effective resistance against neoliberal restructuring as they had in the past. In this case, the old had to be paralysed before the new could be born.

But a neoliberal order needed more than a temporary weakness in the labour movement for the guarantees and privileges of the past had to be abolished as the standard for labour relations. The new post-Fordist relations of production required a flexible workforce, one without job security, one willing to work when needed to fill the short term contracts for production of the new globalized supply chains.

This neoliberal order also needed new state institutions that would enforce the new social relations of production. The biases of the new labour code reflected the new neoliberal ethos: capital rules. If workers resisted, the rules of the state would enforce discipline. The rationale and purpose behind the labour code changed from protecting the rights of workers to promote social peace, to enforcing labour discipline for the benefit of capital.

However, this change in the role of the state required the invocation of a 
new myth, the myth that the state was incapable of effectively regulating labour relations for economic efficiency. In this view, any intervention in any market would automatically lead to corruption and subversion of market justice. Since the state should never ever intervene, citizens could never demand that politicians intervene on their behalf. The political power of the masses was hence made moot once it was agreed that it is not legitimate for the state to intervene on their behalf in relations of production.

Of course the irony, the hypocrisy of the neoliberal position was that the state always secured and regulated social relations of production. As this chapter has demonstrated, the new flexible relations of production required a labour code that prevented unions from effectively defending their members. Thus the neoliberal state was capable of defending the interests of capital, but not the interests and desires of its working class.

However, once neoliberal values became part of the common sense of society, they became self validating. If the people believed that the state should not interfere with the market, then the people would not expect or demand that the state be responsible for market outcomes, and the state would be neutralized.

But the requirement for a system that was biased against workers in turn worked against the long term stability of Fujimori's regime. In order to maintain the anti-union regime, the state had to be autonomous from pressures from civil society. The very autonomy that had allowed Fujimori the Caesarist dictator to impose a new labour regime meant that Fujimori did not develop lasting ties to 
organisations in civil society or to a permanent political party. Without a secure basis in civil society, Fujimori's regime became more and more dependent on shadowy corrupt figures like Montesinos, until the fall of Montesinos drove Fujimori from power. At the same time, this system weakened all actors in civil society until there was no basis for the development of a new mass neoliberal movement that could provide a replacement for Fujimori. Because there was no support for new organisations in civil society, none were created that could articulate neoliberal values as a stable hegemonic order.

The question that remains is: what did the regime of Fujimori represent - a transitional Caesarist dictatorship that once overthrown would be replaced by a hegemonic and hence stable neoliberal order? Alternatively, was the instability of the Fujimori regime a reflection of the inherent contradictions and failure of neoliberalism? This topic will be the subject of the conclusion. 


\section{Conclusions:}

A new order with all its imperfections and injustices was born in Peru under President Fujimori with the hope of resolving an economic crisis. The central research question for this thesis has been how was it possible for a political outsider like Fujimori to impose a full scale reform of the Peruvian state, economy and society along neoliberal lines. Reforming the economy required and entailed more than a simple change in some government policies. Change required a new ethos to justify new state structures which enforced new rules that supported a new dominant pattern for relations of production.

Transformation has been examined both as a process and for the content of what was created. Underlying the process was a series of affinities between neoliberalism as an economic and ideological project and the political interests of Fujimori. The pattern of these affinities was that they were mutually reinforcing, where changes to one area supported changes in all other areas which in turn reinforced and reproduced themselves and each other. A new order did take hold when objective, subjective and institutional structures reinforced each other. Yet at the same time there was nothing inevitable about the shape these changes took. Once state-led industrialization was hit by a crisis of accumulation, there was nothing inevitable about the answer being neoliberalism, except for pressure from the IFIs. Any order that was mutually reinforcing, that offered hope and solutions to Peru's immediate problems while dissolving old structures and institutions, could have effectively replaced García's failed populist experiment. Yet despite neoliberalism's weaknesses and failures elsewhere, it was chosen 
as the overall model around which Peru was reconstructed. This thesis provides an explanation as to why neoliberalism worked as a political project, even if it was an ethical and economic failure.

\section{The Structure of the Argument}

Chapter One revealed the depths of the crisis that Fujimori faced when he swept to power. The legitimacy of the entire order vanished with the collapse of the economy, the failure of the state and the subsequent defenestration of all the political parties. The inability of the Peruvian state to defend Peruvians against the attacks of Sendero undermined their confidence in their political leaders. Sendero disrupted and dislocated the Sierra and its annihilation squads decimated the leadership of civil society thus shattering democratic linkages between Peruvians and their state.

Whatever and whomever Sendero missed were destroyed instead by the economic crisis. A combination of hyperinflation and hyper recession sundered Peruvians' links to their roles in the economy, as the crisis drove more and more into the informal economy for survival. This loss of place further weakened civil society by undermining class identification when formal jobs either vanished or failed to pay enough for survival. This was a crisis of accumulation that had shattered confidence in state-led industrialization.

The collapse of the previous order had led to a crisis of representation, a failure in faith in Peru's pre-existing political leadership and disarticulated the social bases of the parties. The leaders who spoke of the dreams of state-led 
industrialization became the hollow men whose words and slogans had become meaningless. The left's dreams of revolution had become the nightmare of Sendero. APRA's populist reactivation had exploded in hyperinflation. Peru's racial politics and history of exploitation prevented the existing dominant class from regaining political power under Vargas Llosa and then instituting neoliberal reforms. Fujimori's lack of connections to failed political and economic elites ironically made him more powerful not less. The power to resolve the crisis was devolved to an independent outsider, a Caesarist dictator.

Utilizing the model of a Caesarist dictator to understand Fujimori represents a development in our understanding of both the Peruvian case, and our understanding of transformations in general. Previous explanations for Fujimori's authoritarian tendencies have focused on the personal - either his personal preferences or his personal political need to avoid the consequences of scandals (see the introduction for a complete literature review). But in a Caesarist situation, the previous order's implosion has so bankrupted leaders from both the political sphere and civil society that no one possessed the legitimacy required to overhaul all institutions from the constitutional order of the state to institutions that support relations of production. In this situation, Fujimori appeared from outside with the duty to resolve all crises.

A Caesarist dictator appears as a response to a crisis in the order where there is a crisis in domination, accumulation and representation that shatters any remnants of hegemony. The crisis in domination manifested itself as a crisis in common sense, wherein failures in the development project of state-led 
industrialization became a crisis in confidence in the order as a whole. What happened in this case was a loss of faith that state-led industrialization would lead to increasing prosperity and development. The economic crisis combined with the security crisis caused by Sendero destroyed Peruvians' faith in their political leaders, which created a political vacuum for Fujimori to fill.

From this perspective, the explanation for the autogolpe shifted from the personal to the structural, from why Fujimori launched the coup to why Peruvian democracy fell without mass protest. While Fujimori may have been motivated by a personal predilection for authoritarian solutions or by the need to short-circuit investigations into scandals or by a refusal to compromise over economic reforms or by the need to defend the impunity of the military and hence prevent a coup, this explanation provides us with a structural explanation for the public's support of the autogolpe. Fujimori's role was to dissolve the old institutions that had failed and create new institutions that would reinforce a new order in the economy and the state based on neoliberalism.

This use of the model of a Caesarist dictator to understand the authoritarian nature of Fujimori's government also represent a useful theoretical development on O'Donnell's model of delegative democracy. Across Latin America, electorates turned over all power to presidents who then, as part of imposing structural adjustment policies were given the authority to reform all institutions and rules without hindrance. But by utilizing this theory of Caesarism, we can understand that these radical changes made sense as part of the process of transformations. For this process to move forward, a leader had to 
have the authority to transform all the rules and all the institutions that had grown up within the old system. Institutional vetoes also had to be suspended, so that everything could be changed. The depths of the crisis of the previous system, as well as a lack of new forces that would support change, then dictated just how much authority would need to be granted to the leader. So the strength of the delegation of authority to Fujimori was a symptom of the extent of the crisis of state-led industrialization in Peru and how much had to be transformed.

Neoliberalism provided the basis for more than just a set of reforms to the state institutions and economic arrangements, it also provided an ideology, an ethos for a new order. Chapter Two examined the political results of neoliberalism's ideological arguments. Neoliberalism provided a normative basis for a renunciation of the previous consensus on the possibility of an interventionist state that could provide development and secure social justice. Neoliberalism provided a set of arguments that state intervention in the market would not only lead to economic disaster but also threaten liberty itself. This inversion of values then justified the privatization of state enterprises, the end of state intervention in the market and its duty to foster social justice.

Yet these ideas were not simply a reflection of material interests, for they pre-existed neoliberal arrangements in society. The new financial wizards who profited from the drive to deregulation and privatization were created within the new economic and legal order created by neoliberalism. Thus neoliberalism as an ideology was not just a passive reflection of new relations of production; it helped create them. A model of structural affinity describes how these ideas 
came to affect and articulate the new neoliberal order. Because they justified and legitimated a new social ethos, or, as this thesis has demonstrated, especially undermined the values of the previous order, neoliberalism was used to justify the removal of the state from the economy.

If Chapter Two explored the political results of the values of neoliberalism, Chapter Three demonstrated how those values were politically useful for specific political actors. The collapse of the previous order of state-led industrialization created a crisis that cleared the way for a Caesarist dictator who would impose a new order from outside. Fujimori despised political parties for representing a partidocracia, his term for the cabal of corrupt leaders who had looted and destroyed Peru. To be able to purge the system of corruption, Fujimori centralized all power into his own hands. There was to be no legislative or judicial checks on his power, nor was he to be limited by the numbers of terms he could serve. His resolution of the crisis was to create an authoritarian system. Authoritarianism was the hidden bond that held together Fujimori's coalition. The armed forces shared Fujimori's distaste for politics and valued the immunity from prosecution and interference that authoritarianism granted them. Neoliberal technocrats, in turn, valued the autonomy from interference by social forces they were granted under Fujimori's regime. But, more importantly, the neoliberal approach legitimated his regime by providing a project around which authoritarian actors could ally. Neoliberal theorists argued that it would take twenty years before the neoliberal market revolution would bear fruit. Thus the neoliberal project legitimated creating a political system designed to ignore 
demands for action from the same old corrupt political actors. But ignoring special interests became ignoring all demands from society, which in turn justified creating an authoritarian state immune to all inputs. According to the alliance behind Fujimori,Peru required a course of authoritarian medicine to purge Peru of its corruption and institute neoliberal values economic relations and institutions.

However, despite neoliberalism's usefulness for Fujimori, he did not start off as a doctrinaire neoliberal. How Fujimori was converted to neoliberalism and the role played by the international financial institutions (IFIs) was the subject of Chapter Four. The central force for Fujimori's conversion to neoliberalism was the pressure brought to bear by the IFIs. Faced by the unified front of the IFI's who acted as gatekeepers for Peru's access to international capital, Fujimori capitulated to their demands for shock policies and structural adjustment.

However this thesis also points out that the power of the IFI's also depended upon the political and economic conjuncture of its target countries. The depths of the crisis in Peru granted the IFI's the ability to insist on extremely orthodox structural adjustment policies along neoliberal lines in return for renewed access to international capital. As the Peruvian case demonstrates, the IFIs were neither neutral nor helpless in securing the new hegemonic order. The threat of the loss of their imprimatur gave the IFI's a veto over Peru's economic strategy, which was ironic since their blacklisting of Peru was one of the central causes of its economic collapse.

But once the process of structural adjustment was underway, IFI support 
for neoliberal technocrats reinforced neoliberal policy choices. At crucial junctures in the reform process, the IFIs indicated their support for those technocrats who would not only implement their preferences, but do so zealously. These neoliberal technocrats formed a cadre based on their connections to the international caste of policy experts who consulted for the IFIs. Yet these same technocrats lacked connections to the previous order either to its political elites or to its bourgeoisie, they were not beholden to the old order and thus were free to impose new structures. This made them useful for both a Caesarist dictator seeking to dissolve old structures and the IFIs which needed zealous technocrats willing to impose painful changes.

What was created by these changes was the subject of Chapter Five. The core policy changes of the Washington Consensus integrated Peru into the globalized production chains of neoliberalism's new world order. Globalization shattered Fordism's links at the national level between production and consumption, productivity and profits through the internationalization of markets and production chains. Consumption was now focused into an international consumer class concentrated in the centre. Production was converted to global needs, with the periphery providing primary goods and cheap labour for labour intensive consumer goods and thrilling exotic locations for leisure. Productivity was increased, not through increased investment in capital goods, but through squeezing labour costs through relocation. Profits were derived from marketing as well as the squeeze on labour. Savage capitalism replaced the virtuous cycles of Fordism. 
In the Peruvian case, tariff reform bankrupted the local producers of durable consumer goods while opening its market for the centre's producers. On the production side, the reduction of the size of the state reduced taxes, while flexibilization and privatization reoriented Peru into being a more efficient producer of minerals. The IFI's made Peru safe for capital.

At the same time, the state was reconstructed to enforce increased capital accumulation by gutting union power, the subject of Chapter Six. Labour market reforms were justified under the rubric of flexiblization. But what this entailed was a dismantling of effective union tactics by outlawing paros, and generally depoliticizing labour relations. Closed shops were eliminated in the name of "right to work" legislation while the right to organize was eliminated for most workers. The ability to call strikes was curtailed by manipulating strike votes, and also by transforming long strikes into a mass resignation. The role of the state was transformed from that of an arbiter who in the end would intervene to impose a solution and guarantee social peace to an enforcer for the interests of capital.

Past the moment of transition, what was the shape of this new order based on neoliberalism? What structures can be deduced from reforms made to the state, new rules for social relations of production, and the values of neoliberalism? In terms of the state, the need for a Caesarist regime obscures what may or may not be permanent features of a neoliberal state. Any Caesarist regime will resolve the political, economic, and social impasse that faces it by seeking to isolate itself and impose institutional reforms from outside. Thus 
Fujimori's authoritarianism was at least partially a reflection of the depth's of Peru's crisis, as opposed to the structural requirements of neoliberalism.

But what were the political effects of the requirements of an authoritarian Caesarist dictatorship on Fujimori's regime? While an authoritarian state was useful in the short run for the implementation of a neoliberal order, in the long run the isolation of that regime proved to be its downfall. While a complete retelling of the decline and fall of Fujimori's dictatorship lies beyond the scope of this thesis, some of the details of its collapse are pertinent and illuminating.

\section{The Irony of Authoritarianism}

The irony of Fujimori's situation was that the very isolation that granted him the capability to restructure Peru's economy and institutions also left his regime prone to its sudden collapse in the fall of 2000 . Isolation from social forces left Fujimori dependent on the corrupt machinations of Vladimir Montesinos until Montesinos's fall brought down the entire regime. But even a brief perusal of the history of Fujimori's regime will reveal that this isolation was structural and systemic rather than just a reflection of Fujimori's personal failings.

As we have seen, a Caesarist dictator like Fujimori rules from outside and above society to resolve conflicts that are at an impasse. Because the dictator must be independent, his or her regime is totally dependent on support for that dictator as an individual. This meant that in the case of Fujimori's regime, the political survival of his system depended upon his continuation in office with a third re-election. In fact after his fall from power, the candidate who represented 
his movement, Carlos Boloña, received only $1.69 \%$ of the vote, and his movement's list was reduced to four seats out of one hundred and twenty'.

The imperative to generate support for his third mandate drove his regime to ever increasing levels of corruption and manipulation. Fujimori relied on corruption and blackmail to control the political elite and what has been described as techno-populism ${ }^{2}$ to generate support from the masses. Because the imposition of neoliberalism required that Fujimori be isolated from all organized groups, he created no new civil society organizations to generate mass loyalty. Indeed, one of the crucial strategic characteristics of neoliberalism was that class conflict was repressed by the state renouncing its duty to interfere in class relations- at least on the side of subordinate classes (see Chapter Two and Six). Refusing to act disarticulated class resistance by dislocating the traditional tactics of the labour movement, by turning their old strategic actions like paros into farces.

But the price for disarticulating and dislocating every civil society organization including the unions was that no one was left with whom Fujimori could ally. In fact instead of reaching out to independent groups in society,

Martin Tanaka, "Political Restraints on Market Reform in Peru" in PostStabilization Politics in Latin America, ed. Carol Wise and Riordan Roett (Washington D.C.: Brookings Institute, 2003), ff 10, 227.

Carlos Ivan Degregori, Jose Coronel, and Ponciano del Pino, "Government, Citizenship and Democracy: A Regional Perspective," in Fujimori's Peru: The Political Economy, ed. John Crabtree and Jim Thomas (London: Institute of Latin American Studies, 1998), 245. 
Fujimori relied on personal contacts and his personal distribution of goods to generate support from his political base in the informal and rural sectors. In 1992 he created the Ministry of the Presidency to distribute his largesse - a ministry that by 1998 was distributing $22.2 \%$ of the national budget. ${ }^{3}$ The funds that supported this neo-populist giveaway were derived from funds generated from privatization. The sale of Peru's state telephone company to Spanish investors generated over $\$ 2$ billion, of which Fujimori spent $\$ 876$ million on poverty alleviation projects ${ }^{4}$. But while Fujimori did deliver the goods to his supporters in the poorest sectors, these resources did not reflect a systemic change in distribution. Poorer communities did not receive the right to these resources, nor were they given the power to generate these resources themselves through taxation. Instead these were one time gifts from their President.

Fujimori also demonstrated his neo-populist touch in his distribution of resources to the comedor popular, the popular soup kitchens. These comedores and vaso de leche were grassroots organizations that had sprung up in response to the economic crisis under García (see Chapter One). By 1999, there were over ten thousand soup kitchens in Peru, with over 4500 in Lima alone..$^{5}$ In the poorest section of Peru's population, Class D, $41 \%$ regularly relied on the

3

Roger Atwood, "Democratic Dictators: Authoritarian Politics from Leguia to Fujimori," SAIS Review 21, no.2 (2001), 167.

4

Kenneth M. Roberts, "Neoliberalism and the Transformation of Populism in Latin America: The Peruvian Case," World Politics 48, no.1 (1996), 104.

5"Mechanica Naranja", Caretas 1573 (June 24, 1999). 
comedores for food, while $68 \%$ at least had access to them. ${ }^{6}$ Peruvians relied on these institutions for their very survival.

Instead of supporting these autonomous organizations, in the drive for his third election Fujimori redirected resources through Pronaa (Programa Nacional de Asistencia Alimentaria, the government food agency) from the comedores to government distribution centers. These centres distributed individual food aid parcels instead of supporting the communal popular kitchens. This undercut one of the few forms of social organization in the pueblos jovenes. The new food depots were crassly and obviously associated with Fujimori since they were decorated with large orange banners (orange was the colour associated with Fujimori's movements Cambio 90 and Nueva Majoria,) which read "Presidencia del República". ${ }^{7}$ The message was clear to the poorest of the poor: this day President Fujimori had given you your daily bread.

In the run up to the election of 2000 , Fujimori also used the distribution of aid to bully and bribe municipal leaders into joining his movement. The leading opposition candidate before the election was the Mayor of Lima, Alberto Andrade. Andrade had formed a coalition of municipal leaders into Somos Peru (We are Peru), to support his presidential campaign. In response, Fujimori formed his own electoral machine to contest the municipal elections of 1998 :

6

"Mechanica Naranja", Caretas 1573 (June 24, 1999). Class D comprised 58\% of the population.

7“Mechanica Naranja”, Caretas 1573 (June 24, 1999). 
Vamos Vecinos (Let's go Neighbours). The stick the government used to undermine Somos Peru was to deny Pronaa funding to those who remained loyal, while those who defected were rewarded with increased Pronaa spending, as well as tractors, schools and swimming pools. ${ }^{8}$ In the drive to a third mandate, Fujimori used government spending to buy his election from the people.

But beyond his attempt to buy the people's support, Fujimori's regime became increasingly corrupt at the elite level. Vladimiro Montesinos was in control of the National Intelligence Service (SIN). He was officially only an advisor to Fujimori, but unofficially the second most powerful figure in Peru. During Fujimori's second term he gained control over the armed forces through corruption and carefully controlling promotions, especially through the promotion of his former military academy classmates of the year $1966 .{ }^{9}$ The military, which had prided itself in its professionalism, was compromised.

Montesinos's web extended beyond the military to his cronies in the attorney general's office who would prosecute his enemies and protect his

8

"Somos Peru acusa al gobierno de chantejear al alcades," La República, internet version, August 25, 1999.

9

Ernesto Garcia Calderón, "Peru's Decade of Living Dangerously: High Anxiety in the Andes." Journal of Democracy 12, no.2 (2001), 49. Montesinos was a former Army captain who had been cashiered for selling military secrets to the U.S. Montesinos would reward corrupt army officers by posting them to the Selva where they would be amply rewarded by narcotraficantes for turning a blind eye to the transport of cocaine base. 
friends. ${ }^{10}$ The judiciary was undermined by being staffed with only temporary appointments, appointments that left judges subject to Fujimori's pleasure. The authority of the judiciary was also compromised by the creation of "executive commissions" which were granted broad powers of investigation and placed above both the attorney general and the Chief justice of the Supreme Court. Montesinos had subverted the rule of law.

The most famous case of interference with the judiciary, and the case that symbolized Fujimori's usurpation of authority over the courts was his firing of three of the seven judges of Peru's Constitutional Tribunal in 1997. The judges had ruled in a minority opinion against the "law of the Authentic Interpretation of the Constitution", a law that granted Fujimori the right to run for a third mandate despite the fact that the constitution only allowed two terms. ${ }^{11}$ When these judges were fired, it symbolically communicated to the electorate that no one and nothing would be allowed to prevent Fujimori's third election.

This determination to allow nothing to prevent re-re-election ${ }^{12}$ was also reflected in Fujimori's war on the independence of the media. This assault was a byzantine war of intimidation, with secret threats leaked, bugging of the opposition exposed and yet denied, physical attacks on journalists, and an

\footnotetext{
${ }^{10}$ Garcia Calderón, 49.

${ }^{11}$ Tanaka, 226.

12

The opposition's term for a third mandate, which mockingly referred to the government's assertion that this election only counted as a second election since it was only the second term under the new constitution.
} 
advertising campaign by the military against a Congressman and the owner of a newspaper. The overall message to the media was to watch what they reported or else.

In the first six months of 1997 there were over sixty assaults and crimes committed against members of the press. ${ }^{13}$ In one case, a journalist Blanca Rosales, was kidnaped for an hour and then let go. No possessions were stolen; yet the police claimed that this was just a simple case of robbery which had been conducted by ordinary criminals. ${ }^{14} \mathrm{~A}$ message was sent to the press: the military could punish transgressors with impunity.

The security services indicated that they were watching everyone by leaking a bugging scandal in 1997. Someone had bugged the phone conversations of over 197 different persons: journalists, opposition Congressmen, businessmen and a variety of officials. ${ }^{15} \mathrm{Fujimori}$ declared that the bugging was only the work of some unknown individual, an assertion that was patently false since the equipment required to bug this many people would have cost $\$ 250,000$, and was typically only used by intelligence agencies. ${ }^{16}$ If the leak was deliberate, then the message was that the intelligence service was always

13

Julio Castillo, "Los mas graves atendados contra la prensa en 1997." La República, 23 July 1997, 16-17.

${ }^{14}$ Castillo, 16-17.

${ }^{15}$ David Montoya, "Informe Seminal " Mira! El Sol, 13 July1997, 6-7. 16

NA. "Una central inceptacen simultaneo hasta 500 telefonos," La República, 1 August 1997. 
listening to the phones of journalists and the opposition. Whistle blowers take note: be silent.

But the most serious case was the case of Baruch Ivcher. Baruch Ivcher was the owner of Frequencia Latina, a television station. At first he was accused of brokering an arms deal for Ecuador, a serious accusation since Peru and Ecuador were fighting a limited border war at the time. When this charge failed to stick, he was stripped of his Peruvian citizenship over irregularities in his naturalization. To own a television station in Peru one must be a citizen, so the courts stripped him of his ownership and Ivcher fled into exile.

The reason that Ivcher was targeted was that his station had discovered that uncovering government and military scandals led to high ratings. His programs had broken the scandal of Leonor La Rosa and the Grupo Colina which in turn threatened their master Montesinos. ${ }^{17}$ The attack on Ivcher punished someone who had turned traitor, silenced critics of the regime, and established limits on investigative journalists.

Overall in 2000, Fujimori drove to re-re-election over civil society. Spaces and organizations in civil society like the unions and comedors were undermined in a quest to generate support. The judiciary was corrupted, compromised and brought under Montesinos's thumb. The media was turned into a propaganda

17

Silvia Rojas, "La Activo llamado credibilidad," Domingo, La Republica, 20 July 20 1997, 10. Leonor La Rosa was a former member of the SIN death squad Grupo Colina. She was picked up, tortured and left crippled on suspicion of leaking details of the team's crimes to the press. Her accusations were a story for months in the Peruvian press. 
tool praising the President. Sources of opposition were silenced, threatened, compromised and colonized to prevent defeat.

But despite Fujimori's attempt to silence all opposition and centralize all power in an authoritarian government, his regime quickly collapsed in 2000 . The irony was that while government pressure undermined organizations in civil society, his regime failed to establish legitimate new organizations that could generate mass loyalty. While he transferred resources into his own paternalistic and populist distribution centres, he only alienated the women of the comedores without creating a new organic, independent set of organizations that supported him. He may have bought municipal leaders, but those who were bought were seen as corrupt rather than authentic representatives of the people. He may have silenced independent television stations by shifting control to his supporters, but no one believed the propaganda. The irony of authoritarianism was that in centralizing all power into his own hands, Fujimori weakened all the intermediary organizations of civil society that could have defended him in a crisis.

This inability to develop independent civil society organizations points to one of the key differences between original form of populism and the neoliberal variant of neo-populism. Under the original version of populism under APRA in the 1930's, there was at least an attempt to integrate new urban classes by organizing soup kitchens, popular education classes, and unions. These institutions were then used to recruit members into APRA. But under Fujimori, independent popular organizations were a threat, and political parties were only 
a source of corruption. According to neoliberal thought, any popular organization that made demands was, by definition, corrupt. New social groups in the informal economy were not to be organized and integrated. They must be left atomized for the new relations of production to succeed.

The crisis that overturned the regime developed quickly and overwhelmed his regime till it melted like snow in July. While Fujimori had secured his re-reelection (albeit in a way that was so suspicious that the OAS refused to sanction the results), he had failed to win a majority in Congress. ${ }^{18}$ Then, on September $14^{\text {th }}, 2000$, a video was leaked of Vladimiro Montesinos bribing a Congressman to defect to Fujimori's party ${ }^{19}$ Two days later, with Montesinos in control of the military and the intelligence service, Fujimori called for new elections for July of 2001, dissolved SIN and fired Montesinos. ${ }^{20}$ Montesinos fled the jurisdiction, and more and more Vladivideos were released revealing the extent of the corruption of Fujimori's followers in Congress, the military and the administration. In November Fujimori resigned and fled into exile in Japan. Like those of Napoleon III or Mussolini, when Fujimori's government collapsed, it completely vanished.

But what was the meaning of this collapse for the central argument of this thesis - that Fujimori was a Caesarist dictator elected to resolve a crisis of the order? While at first Fujimori's successes like the capture of Guzman and the

\footnotetext{
${ }^{18}$ Tanaka, 237.

${ }^{19}$ Tanaka, 241.

${ }^{20}$ Garcia Calderon, 53.
} 
subsequent defeat of Sendero generated support, in the longer run, they diminished the need for a Caesarist dictator. Once the economic crisis was resolved by the imposition of reforms and economic stability returned, a master was no longer needed to impose a new order. During his second term, the drive for Fujimori's third election became less about the need for radical reform and more and more about keeping power.

But even if success drained Fujimori's regime of its mission and plunged it into corruption, what role did the neoliberal project play in its authoritarianism? While corruption is often a result of an authoritarian regime, the role that creating a neoliberal order played in creating the need for such a regime is discussed in the next section.

\section{The Responsibility of Neoliberalism}

The requirements for a neoliberal order cannot be completely absolved of the blame for the authoritarian nature of Fujimori's Peru. At a superficial level, neoliberal technocrats formed a critical support base for Fujimori and provided the expertise he needed in his cabinet, as well as crucial connections to the IFIs. Neoliberalism as a project also cemented Fujimori's alliance with the armed forces. Transformation itself required that power be centralized in the hands of the executive, so that everything could be changed without hindrance from social forces.

In the case of Peru, Fujimori used authoritarian measures to impose the 
kind of state-society relations needed by a neoliberal order. The central goal of the neoliberal approach was to minimize the sphere of state activities. The state was not to ameliorate nor regulate the excesses of capitalism; nor was it to be allowed to mediate class conflicts. The state was to abandon its responsibilities for services, turning over health care, education, water and power to private capital. In order to achieve this kind of state, the state had to be completely impervious to demands from society. Power was centralized in the hands of the executive which created a disciplined and autonomous state capable of enforcing neoliberal rules. In the case of Peru, a Caesarist dictatorship was certainly useful for the transformation to a neoliberal order.

But past the time of transition, even if it takes twenty years, can neoliberalism move from domination to consent? The problem for neoliberalism is its own failure to increase prosperity for everyone. Increasing levels of inequality combined with a decline in standards of living for subordinate classes may prove to be neoliberalism's Achilles heel.

Indeed the weakness of neoliberalism in establishing consent was revealed in the politics of Peru after Fujimori. After an interim caretaker government, Fujimori's replacement was Alejandro Toledo, a candidate who came out of nowhere to challenge him in 2000 . Toledo provided a challenge to Fujimori based on ethnicity for he was a Stanford-educated economist who was also an Indio. But like Fujimori, he was an outsider to established politics and his party vehicle Perú Posible was an improvised organization without strong 
connections into society. ${ }^{21}$ The party's Congressional list was dominated by those with personal connections to the elites and militants from other failed parties. ${ }^{22}$ Once in office, Toledo's popularity plummeted when he tried to implement the privatization policies of the IFIs.

What this indicates about neoliberal policies is that they do not develop their own civil society organizations or a permanent political party. There was no political vehicle that articulated the values of neoliberalism, that organically represented the new classes it created, that was capable of taking over once Fujimori was defeated.

On the other hand, Toledo's inability to provide an alternative to neoliberal policies points towards their persistence once they were enshrined. Once Fujimori had established the new order, Toledo lacked the capability or the power to overturn it in the face of opposition of the IFIs. There still was no alternative to neoliberalism.

But beyond the economic shortcomings of this approach, the requirement for absolute autonomy from social forces may doom it in the long run. Autonomy from pressure also entails isolation. If the state does not serve, if it does not provide services then how will it buy loyalty or co-opt subordinate classes? If the neoliberal state is based on ignoring civil society, how will it create new organizations to reproduce its values?

\footnotetext{
${ }^{21}$ Tanaka, 238.

${ }^{22}$ Tanaka, 241.
} 
The biases of the neoliberal order towards the interests of capital may be too blatant to be sustain these relations of production. While individualismo, and the atomization of the workplace may undermine resistance in the short run; in the long run, memories and habits of the successes of collective action may create sites of rebellion. From these islands of resistance, blatant exploitation may once again create a counter-hegemonic bloc dedicated to the overthrow of neoliberalism.

However, the moment of state-led and owned industrialization where unions were born within large scale production sites is probably gone for good. Post-fordist relations of production have replaced the old mass production lines with decentralized production sites and polyvalent, independent workers. Wages for these workers will be kept compressed by international competition, despite increases in productivity. The shift in the balance of power between labour and capital has led in turn to global over-accumulation, bubble capital markets and recurring crashes. The contradiction of this global realization crisis may ultimately lead to a global crisis within a neoliberal world order, when those who produce, eat nothing, and those who don't, buy everything.

From an international perspective, neoliberalism seems to be enshrined not by consent but by quiescence. The consequences of rebellion against the powers of the IFIs are too high, the certainty of disaster too strong for any responsible leader to attempt escape. Fatalism and a sense of the futility of attempting any other order secures the international system of neoliberalism. But at the same time the inequality generated and enshrined by neoliberalism 
has sparked a wave of rebellions against it across Latin America. But whether or not Chavez's Bolivaran revolution represents a truly sustainable alternative paid for by Venezuelan oil revenues remains to be seen.

The study of how Peru was changed revealed the importance of the implosion of the previous order of state-led industrialization. The death of the old created a vacuum that allowed the birth of the new. But a new economic direction for Peru involved more than simply reforming some policy choices. It involved a radical transformation of the state, relations of production in the economy and a change in the normative base that governed these institutions and relationships. What had to be changed was the entire political, economic and moral order of Peru. 


\section{Appendix A}

\section{Sample Questions for Technocrats}

1. What was your educational background?

2. How were you recruited into the government?

3. What was or is your position?

4. When you let go the previous government' appointees, was there pressure to appoint any friends of the government? Were you pressured to direct funds towards communities that had supported the government?

5.In your opinion, how should policy be formed, by experts or in response to demands from the public?

6. What is your opinion of the autogolpe? Did you support it at the time?

7.What is the role of the government and the relationship between business and workers?

8. What do you think about the government's actions in the Ivcher case?

9.What do think about flexibilization and labour market reforms?

10. Do unions offer any expertise that would be useful for making decisions about the labour code?

11. Do you see economics as a science that demands certain universal policies? 12.In your discussions with the World Bank and IMF did they demand more or less stringent labour market reforms?

13.What do you think the proper role of labour unions should be in collective bargaining? In the workplace? 


\section{Bibliography}

\section{Books and Monographs}

Adamson, Walter L. Hegemony and Revolution: A Study of Antonio Gramsci's Political and Cultural Theory. Berkeley: University of California Press, 1980.

Adorno, T.W., et al. The Authoritarian Personality, Part Two. New York: John Wiley \& Sons, 1950.

Aguero, Felipe and Jeffrey Stark, eds. Fault Lines of Democracy in Posttransition Latin America. Miami: North-South Center Press, 1998.

Alba Victor. Politics and the Labor Movement in Latin America. Stanford: Stanford University Press, 1968.

Allen, John, Peter Braham, and Paul Lewis, eds. Political and Economic Forms of Modernity. London: Polity Press, 1992.

Alvarez, Sonia E. Engendering Democracy in Brazil: Women's Movements in Transition Politics. Princeton: Princeton University Press, 1990.

Alves, Maria Helena Moreira. State and Opposition in Military Brazil. Austin: University of Texas Press, 1985.

Amado, Jorge. The Golden Harvest, tr. Clifford E. Landers. New York: Avon Books, 1992.

Arendt, Hannah. Between Past and Future: Eight Exercises in Political Thought. New York: Penguin Books, 1968.

Arendt, Hannah. Eichmann in Jerusalem. New York: Viking Press, 1964.

Arendt, Hannah. The Human Condition. Chicago: The University of Chicago Press, 1989.

Arendt, Hannah. The Origins of Totalitarianism. New York: Harcourt, Brace \& World, Inc., 1966.

Bacchus, Wilfred A. Mission in Mufti: Brazil's Military Regimes, 1964-1985. New York: Greenwood Press, 1990.

Bethell, Leslie, ed. Chile Since Independence. Cambridge: Cambridge University Press, 1993.

Black, Jan Knippers, ed. Latin America, Its Problems and Its Promise: A Multidisciplinary Introduction. Boulder: Westview Press, 1984.

Boloña, Carlos Behr. Cambio de Rumbo: El Programa Economico para los 90. Lima: Instituto del Economia de Libre Mercado, 1995. 
Bosworth, Barry P. et al, eds. The Chilean Economy: Policy Lessons and Challenges. Washington, D.C. : The Brookings Institution, 1994.

Bottomore, T.B. Elites and Society. Harmondsworth: Penguin Books, 1964.

Bluestone, Barry and Bennet Harrison. The Great U-Turn: Corporate Restructuring and the Polarizing of America. New York: Basic Books, 1998.

Brock, Philip L., et al, eds. Latin American Debt and Adjustment: External Shocks and Macroeconomic Policies. New York: Praeger, 1989.

Cameron, Maxwell A. Democracy and Authoritarianism in Peru: Political Coalitions and Social Change. New York: St. Martin's Press, 1994.

Cameron, Maxwell A. and Philip Mauceri, eds. The Peruvian Labyrinth: Polity, Society, Economy. University Park, Pennsylvania: The Pennsylvania University Press, 1997.

Cardoso, Fernando Henrique and Enzo Faletto. Dependency and Development in Latin America. Berkeley: University of Caliornia Press, 1979.

Caufield, Catherine. Masters of Illusion: The World Bank and the Poverty of Nations. New York: Henry Holt, 1996.

Caviedes, César. The Southern Cone: Realities of the Authoritarian State in South America. Totawa, New Jersey: Rowman \& Allanheld Publishers, 1984.

Centeno, Miguel A. and Patricio Silva, eds. The Politics of Expertise In Latin America. New York: St. Martin's Press, 1998.

Chilcote, Ronald H., ed. Dependency and Marxism: Towards a Resolution of the Debate. Boulder: Westview Press, 1982.

Chilcote, Ronald H. and Edelstein, Joel C. Latin America: Capitalist and Socialist Perspectives of Development and Underdevelopment. Boulder: Westview Press, 1986.

Chilcote, Ronald H. Theories of Comparative Politics: The Search for a Paradigm Reconsidered. Boulder, Colorado: Westview Press, 1994.

Chossudovsky, Michael. The Globalization of Poverty: Impacts of World Bank and IMF Reforms. London: Zed Books, 1997.

Clapham, Christopher. Third World Politics: An Introduction. Madison, Wisconsin: The University of Wisconsin Press, 1985.

Cline, William R. and Sidney Weintaub, eds. Economic Stabilization in Developing Countries. Washington, D.C. : The Brookings Institution, 
1981.

Cockcroft, James D. Neighbors in Turmoil: Latin America. New York: Harper \& Row Publishers, 1989.

Colclough, Christopher and James Manor. States or Markets: Neo-liberalism and the Development Policy Debate. Oxford: Clarendon Press, 1991.

Collier, David and Collier, Ruth. Shaping the Political Arena: Critical Junctures, the Labor Movement, and Regime dynamics in Latin America. Princeton, New Jersey: Princeton University Press, 1991.

Collins, Joseph and John Lear. Chile's Free-market Miracle: A Second Look. Oakland, California: The Institute for Food and Development, 1995.

Conaghan, Catherine M. and James M. Malloy. Unsettling Statecraft: Democracy and Neoliberalism in the Central Andes. Pittsburgh: University of Pittsburgh Press, 1994.

Constable, Pamela and Arturo Valenzuela. A Nation of Enemies: Chile under Pinochet. New York: W.W. Norton \& Company, 1991.

Corradi, Juan E., et al, eds. Fear at the Edge: State Terror and Resistance in Latin America. Berkeley: University of California Press, 1992.

Cox, Robert W. Power, Production and World Order. New York: Columbia University Press, 1987.

Crabtree, John and Jim Thomas, eds. Fujimori's Peru: The Political Economy. London: Institute of Latin American Studies, 1998.

Dahl, Robert A. Who Governs? Democracy and Power in an American City. New Haven: Yale University Press, 1961.

Dahl, Robert. Polyarchy. New Haven : Yale University Press, 1971.

Dahl, Robert. Democracy and Its Critics.New Haven: Yale University Press, 1989.

Dealy, Glen Caudill. The Latin Americans: Spirit and Ethos. Boulder, Colorado: Westview Press, 1992.

De Soto, Hernando. The Other Path: The Invisible Revolution in the Third World. New York: Harper \& Row, 1989.

Diamond, Larry and Marc F. Plattner, eds. Capitalism, Socialism, and Democracy Revisited. Baltimore: The Johns Hopkins University Press, 1993.

Dewey, John. Freedom and Culture. New York: Capricorn Books, 1939.

Dietz, Henry. Urban Poverty, Political Participation and the State: Lima 1970- 
1990 Pittsburgh: University of Pittsburgh Press, 1998.

Dominguez Jorgel. Technopols: Freeing Politics and Markets in Latin America in the 1990's. State College, Pennsylvania: The Pennsylvannia State University Press, 1997.

Dornbusch, Rudiger and Edwards, Sebastian. The Macroeconomics of Populism in Latin America. Chicago: University of Chicago Press, 1991.

Dornbusch, Rudiger. Stabilization, Debt and Reform. Englewood Cliffs: Prentice Hall, 1993.

Drake, Paul W. and Ivan Jaksic, eds. The Struggle for Democracy in Chile, 19821990. Lincoln, Nebraska: University of Nebraska Press, 1991.

Dryzek John S. Discursive Democracy. Cambridge: Cambridge University Press, 1990.

Edwards, Sebastian and Alejandra Cox Edwards. Monetarism and Liberalization: The Chilean Experiment. Cambridge: Ballinger Publishing Company, 1987.

Ellul, Jacques. The Technological Society, intr. Robert K. Merton; tr. John Wilkinson. New York: Alfred A. Knopf, 1967.

Epstein, Edward D., ed. Labour Autonomy and the State in Latin America. Boston: Unwin Hyman, 1989.

Evans, P. Dependent Development: The Alliance of Multinational, State and Local Capital in Brazil. Princeton: Princeton University Press, 1979.

Finer, Herman. Road to Reaction. Chicago: Quadrangle Books, 1964.

Foucault, Michel. The Archeology of Knowledge, tr. A.M. Sheridan Smith. London: Routledge, 1992.

Foucault, Michel. Power/Knowledge: Selected Interviews and Other Writings, 1972-77, ed. Colin Gordon. New York: Pantheon Books, 1980.

Foxley, Alejandro. Latin American Experiments in Neoconservative Economics. Berkeley: University of California Press, 1983.

Frank, Andre Gunder. Capitalism and Underdevelopment in Latin America: Historical Studies of Chile and Brazil. New York: Monthly Preview Press, 1967.

Freeman, Linda. The Ambiguous Champion: Canada and South Africa in the Trudeau and Mulroney Years. Toronto: University of Toronto Press, 1997.

Freire, Paolo. Education for Critical Consciousness. New York: The Seabury Press, 1973. 
Freire, Paolo. Pedagogy of the Oppressed, tr. Myra Bergman Ramos. New York: Herder \& Herder, 1970.

Friedman, Milton. Capitalism and Freedom. Chicago: The University of Chicago Press, 1962.

Friedman, Milton and Rose Friedman. Free to Choose. New York: Avon Books, 1980.

Friedman, Milton and Rose Friedman. Tyranny of the Status Quo. New York: Harcourt Brace Jovanovich, Publishers, 1984.

Friedrich, Carl, and Zbignew Brezinski. Totalitarian Dictatorship and Autocracy. Cambridge: Harvard University Press, 1965.

Garreton, Manuel Antonio M. The Chilean Political Process. London: Unwin Hyman, 1989.

Garreton, Manuel Antonio M. and Edward Newman, eds. Democracy in Latin America: (Re)constructing Political Society. Tokyo: United Nations University Press, 2001.

Gaventa, John. Power and Powerlessness: Quiescence and Rebellion in an Appalachian Valley. Urbana, Illinois: University of Illinois Press, 1980.

George, Susan and Fabrizio Sabelli. Faith and Credit: The World Bank's Secular Empire. Boulder: Westview Press, 1994.

Gibbon, Peter and Yasuf Bangura and Arve Ofstad, eds. Adjustment, Authoritarianism and Democracy: An Introduction to Some Conceptual and Empircial Issues (from the Introduction). Uppsala : Scandanavian Institute of African Studies, 1992.

Giddens, Anthony. The Third Way: The Renewal of Social Democracy. Cambridge: Polity Press, 1999.

Gill, Stephen, ed. Gramsci, Historical Materialism and International Relations. Cambridge: Cambridge University Press, 1993.

Goodman, Louis W, Joanna S.R. Mendelson and Juan Rial, eds. The Military and Democracy: The Future of Civil-Military Relations in Latin America. Lexington, Massachusetts: Lexington Books, 1990.

Gramsci Antonio. Selections from the Prison Notebooks of Antonio Gramsci, ed. Quintin Hoare and Geoffrey Nowell Smith. New York: International Publishers, 1971.

Gramsci, Antonio. A Gramsci Reader: Selected Writings, 1916-1935, ed. David Forgacs. London : Lawrence and Wishart, 1988. 
Gramsci, Antonio. Prison Notebooks, Volume 1, ed. Joseph A. Buttigieg; tr. Antonio Callari. New York: Columbia University Press, 1992.

Grant, George. Technology and Empire: Perspectives on North America. Toronto : House of Anansi, 1969.

Grant, George. Technology and Justice. Concord, Ontario: Anansi, 1986.

Grant, George. Technology and Empire: Perspectives on North America. Toronto: House of Anansi, 1969.

Green, T. H. The Political Theory of T.H. Green: Selected Writings, ed. John Rodman. New York: Appleton Century Crofts, 1964.

Greenstein, Fred I. and Nelson W. Polsby, eds. Macropolitical Theory, Handbook of Political Science, Volume 3. Reading, Massachusetts: Addison-Wesley Publishing Company, 1975.

Habermas, Jurgen. Between Facts and Norms. Cambridge, Mass.: MIT Press, 1996.

Haggard, Stephan. Pathways From the Periphery. Ithaca: Cornell University Press, 1990.

Handelman, Howard and Werner Baer, eds. Paying the Costs of Austerity in Latin America. Boulder, Colorado: Westview Press, 1989.

Harper, Richard H.R. Inside the IMF: An Ethnography of Documents, Technology and Organisational Action. San Diego: Academy Press, 1994.

Hayek, Friedrich A. The Road to Serfdom. Chicago: The University of Chicago Press, 1965.

Hayek Friedrich A. The Constitution of Liberty. Chicago: Henry Regnery Company, 1960.

Hayek Friedrich A. Law, Legislation, and Liberty, Volume 2: The Mirage of Social Justice. Chicago, University of Chicago Press, 1976.

Hayek, Friedrich A. Law Legislation and Liberty, Volume 3: The Political Order of a Free People. Chicago: University of Chicago Press, 1979.

Higley, John and Richard Gunther, eds. Elites and Democratic Consolidation in Latin America and Southern Europe. Cambridge: Cambridge University Press, 1992.

Hirschman, Albert O. Getting Ahead Collectively. Princeton: Princeton University Press, 1982. 
Hobbes, Thomas. Leviathan, ed. C.B. Macpherson. Harmondsworth, Middlesex : Penguin Books, 1980.

Hojman, David E., ed. Chile After 1973: Elements For the Analysis of Military Rule. Liverpool: The University of Liverpool Centre for Latin American Studies, 1985.

Hyland James L. Democratic Theory: The Philosophic Foundations. Manchester: Manchester University Press, 1995.

Jacobsen, Nils. Mirages of Transition: The Peruvian Altiplano, 1780-1930. Berkeley: University of California Press, 1993.

Janowitz, Morris. The Professional Soldier: A Social and Political Portrait. London: The Free Press, 1960.

Johnson, Dale et al. Dependence and Underdevelopment. Garden City, New Jersey: Anchor Books, 1972.

Kaufman, Edy. Crisis in Allende's Chile: New Perspectives. New York: Praeger, 1988.

Kay, Cristobal. Latin American Theories of Development and Underdevelopment. New York: Routledge, 1989.

Klarén, Peter Flindell. Peru: Society and Nationhood in the Andes. New York: Oxford University Press, 2000.

Laclau, Ernesto. Politics and Ideology in Marxist Theory. London: New Left Books, 1977.

Lal, Deepak. The Poverty of 'Development Economics'. Cambridge: Harvard University Press, 1985.

Levine, Daniel H., ed. Constructing Culture and Power in Latin America. Ann Arbour, Mlchigan: The University of Michigan Press, 1993.

Lipietz, Alain. Mirages and Miracles: The Crises of Global Fordism. London: Verso, 1987.

Lopez, George A. and Stohl, Michael eds. Liberalization and Redemocratization in Latin America. New York: Greenwood Press, 1987.

Loveman, Brian. Chile: The Legacy of Hispanic Capitalism.New York : Oxford University Press, 1988.

Loveman, Brian and Thomas M. Davies, Jr., eds. The Politics of Antipolitics: The Military in Latin America. Lincoln, Nebraska: University of Nebraska Press, 1989.

Loveman, Brian. The Constitution of Tyranny: Regimes of Exception in Spanish America. Pittsburgh: University of Pittsburgh Press, 1993. 
Luttwak, Edward. Coup D'Etat: A Practical Handbook. London: The Penguin Press, 1968.

Macpherson, C.B. Democratic Theory: Essays in Retrieval. Oxford: Clarendon Press, 1973.

Macpherson, C.B. The Real World of Democracy. Toronto: Anasi Press, 1965.

Macpherson, C.B. The Life and Times of Liberal Democracy. Oxford: Oxford University Press, 1977.

Macpherson, C.B. The Political Theory of Possessive Individualism. Oxford: Oxford University Press, 1962.

MacEoin, Gary. No Peaceful Way: Chile's Struggle for Dignity. New York: Sheed and Ward, Inc., 1974.

Mainwaring, Scott, et al, eds. Issues in Democratic Consolidation. Notre Dame, Indiana: Indiana University Press, 1992.

Mainwaring, Scott and Timothy R. Scully. eds. Building Democratic Institutions: Party systems in Latin America. Stanford: Stanford University Press, 1995.

Malloy, James M. and Mitchell A. Seligson, eds. Authoritarians and Democrats: Regime Transition in Latin America. Pittsburgh: University of Pittsburgh Press, 1987.

Marks, Gary and Larry Diamond, eds. Reexamining Democracy: Essays in Honor of Seymour Martin Lipset. Newbury Park, California: Sage Publications, 1992.

Marquez, Gabriel Garcia. One Hundred Years of Solitude. New York: Avon Books, 1970.

Marshall, Adriana, Francisco Verdera V and Isabel Yépez del Castillo. Circumventing Labour Protection: non-Standard Employment in Argentina and Peru. Geneva: International Institute for Labour Studies, 1992.

Marshall T. H. Citizenship and Social Class and other essays. Cambridge: Cambridge University Press, 1950.

Marx, Karl. Karl Marx: Selected Writings, ed. David McLellan. Oxford: Oxford University Press, 1988.

McDonald, Ronald H. and J. Mark Ruhl. Party Politics and Elections in Latin America. Boulder, Colorado: Westview Press, 1989.

Moore, Barrington. Social Origins of Dictatorship and Democracy. Boston: 
Beacon Press, 1966.

Moore, Barrington. Terror and Progress USSR: Some Sources of Change and Stability in the Soviet Dictatorship. Cambridge: Harvard University Press, 1966.

Moore, David B. and Gerald J. Schmitz, eds. Debating Development Discourse: Institutional and Popular Perspectives. New York: St. Martin's Press, 1995.

Munck, Ronaldo. Latin America: The Transition to Democracy. London: Zed Books, 1989.

Munck, Ronaldo. Politics and Dependency In the Third World. London: Zed Books, 1984.

Nelson, Joan M. et al. Intricate Links: Democratization and Market Reforms in Latin America and Eastern Europe. New Brunswick, USA: Transaction Publishers, 1994.

Neumann, Franz L. The Democratic and Authoritarian States: Essays in Political and Legal Theory, ed. Herbert Marcuse. [n.d]: The Free Press, 1957.

Nordlinger, Eric A. Soldiers in Politics: Military Coups and Governments. Englewood Cliff, New Jersey: Prentice-Hall, 1977.

North, Liisa. Civil-Military Relations in Argentina, Chile, and Peru. Berkeley: Institute of International Studies, University of California, 1966.

Nunn, Frederick M. The Time of the Generals: Latin American Professional Militarism in World Perspective. Lincoln, Nebraska: University of Nebraska Press, 1992.

O'Brien, Philip and Jackie Roddick. Chile: The Pinochet Decade. The Rise and Fall of the Chicago Boys. London: Latin America Bureau, Research and Action, 1983.

O'Donnell, Guillermo et al, eds. Transition From Authoritarian Rule: Latin America Baltimore: Johns Hopkins University Press, 1989.

Oquist, Paul. Violence, Conflict and Politics in Colombia. New York: Academic Press, 1980.

Ortiz de Zevallos, Felipe. The Peruvian Puzzle. New York: Priority Press Publications, 1989.

Oxhorn, Philip and Graciela Ducatenzeiler, eds. What kind of Market, What Kind of Democracy, Latin America in the Age of Neoliberalism. University Park Pennsylvania: Penn State Press, 1999.

Oxhorn, Philip and Pamela K. Starr, eds. Markets and Democracy in Latin 
America: Conflict or Convergence. Boulder: Lynne Reinner Publishers, 1999.

Parodi, Jorge. To Be a Worker: Identity and Politics in Peru. Chapel Hill: The University of North Carolina Press, 2000.

Payne, James L. Patterns of Conflict in Colombia. New Haven: Yale University Press, 1968.

Payne, James L. Labor and Politics in Peru: The System of Political Bargaining. New Haven and London: Yale University Press, 1965.

Pereira, Luiz Carlos Bresser et al, eds. Economic Reforms in New Democracies: A Social-Democratic Approach. Cambridge: Cambridge University Press, 1993.

Petras, James. Class, State and Power in the Third World. Montclair, New Jersey: Allenheld Osmun \& Publishers, 1981.

Petras, James and Morley Morris. Latin America in the Time of Cholera: Electoral Politics, Market Economics, and Permanent Crisis. New York: Routledge, 1992.

Pion-Berlin, David. The Ideology of State Terror: Economic Doctrine and Political Respression in Argentian and Peru. Boulder: Lynne Reimer Publishers, 1984.

Polanyi, Karl. The Great Transformation. Boston: Beacon Press, 1970.

Poulantzas, Nicos. The Crisis of Dictatorships. London: New Left Books, 1976.

Poulantzas, Nicos. Political Power and Social Classes. London: New Left Books, 1975.

Poulantzas, Nicos. State, Power, Socialism. London: Verso, 1978.

Przeworski, Adam. Democracy and the Market. Cambridge: Cambridge University Press, 1991.

Puryear, Jeffrey M. Thinking Politics: Intellectuals and Democracy in Chile, 19731988. Baltimore: The Johns Hopkins University Press, 1994.

Pye, Lucien. Asian Power and Politics: The Cultural Dimensions of Authority. Cambridge: Harvard University Press, 1985.

Ramos, Joseph. Neoconservative Economics in the Southern Cone of Latin America, 1973-1983. Baltimore: The Johns Hopkins University Press, 1986.

Rayack, Elton. Not so Free to Choose. New York: Praegar,1987.

Ritter, Archibald R.M., David H. Pollock and Maxwell Cameron, eds. Latin 
America to the Year 2000: Reactivating Growth, Improving Equity, Sustaining Democracy. London: Praegar, 1992.

Roberts Kenneth M. Deepening Democracy: The Modern Left and Social Movements in Chile and Peru. Stanford: Stanford University Press, 1998.

Robinson, Derek. Monetarism and the Labour Market. Oxford: Clarendon Press, 1986.

Rojo, Grinor and John J. Hassett, eds. Chile: Dictatorship and the Struggle for Democracy. Gaithersburg, Maryland: Ediciones Hispamérica, 1988.

Rouquie, Alain. The Military and the State in Latin America, tr. Paul E. Sigmund. Berkeley: University of California Press, 1987.

Rousseau, Jean-Jacques. Rousseau's Political Writings, ed. Alan Ritter and Julia Conaway Bondanella. New York: W.W. Norton \& Company, 1988.

Rudolph, James D. Peru: The Evolution of a Crisis. Westport, Connecticut: Praeger, 1992.

Rueschemeyer, Dietrich et al. Capitalist Development and Democracy. Chicago: University of Chicago Press, 1992.

Saba, Raúl P. Political Development and Democracy in Peru: Continuity in Change and Crisis. Boulder, Colorado: Westview Press, 1987.

Sagaris, Lake. After the First Death: A Journey through Chile, Time, Mind. Toronto: Somerville House Publishing, 1996.

Sartori, Giovanni. Democratic Theory. Detroit: Wayne State University Press, 1962.

Sassoon, Anne Showstack, ed. Approaches to Gramsci. London: Writers and Readers, 1982.

Sater, William F. The Southern Cone Nations of Latin America Arlington Heights, Illinois: The Forum Press, 1984.

Schumpeter, Joseph A. Capitalism, Socialism and Democracy New York: Harper \& Row, 1947.

Sheahan John. Searching For A Better Society: The Peruvian Economy from 1950. University Park, Pennsylvania: The Pennsylvania State University Press, 1999.

Simpson, John and Janice Bennet. The Disappeared: Voices From the Secret War. London: Robson Books, 1985.

Shand, Alexander H. Free Market Morality: The Political Economy of The 
Austrian School. London: Routledge, 1990.

Sheahan, John. Searching for a Better Society: The Peruvian Economy from 1950. University Park, Pennsylvania: The Pennsylvania State University Press, 1999.

Skidmore, Thomas E. The Politics of Military Rule in Brazil, 1964-1985. New York: Oxford University Press, 1988.

Smith, William C. and Roberto Patricio Korneniewicz. Politics, Social Change and Economic Restructuring in Latin America. Miami: North South Centre Press, 1997.

Spooner, Mary Helen. Soldiers in a Narrow Land. Berkeley: University of California Press, 1994.

Stallings Barbara and Robert Kaufman, eds. Debt and Democracy in Latin America. Boulder: Westview Press, 1989.

Starn, Orin, Carlos Ivan Degregori and Robin Kirk, eds. The Peru Reader: History, Culture, Politics. Durham and London: Duke University Press, 1995.

Stepan, Alfred, ed. Authoritarian Brazil: Origins, Policies, and Future. New Haven: Yale University Press, 1976.

Stepan, Alfred, ed. Democratizing Brazil: Problems of Transition and Consolidation. New York: Oxford University Press, 1989.

Stepan, Alfred. Rethinking Military Politics: Brazil and the Southern Cone. Princeton: Princeton University Press, 1988.

Stem, Steve J. ed. Shining and Other Paths: War and Society in Peru, 19801995. Durham: Duke University Press, 1998

Stokes, Susan C. Cultures in Conflict: Social Movements and the State in Peru. Berkeley: University of California Press, 1995.

Strange, Susan. Mad Money: When Markets Outgrow Governments. Ann Arbour: The University of Michigan Press, 1998.

Strong, Simon. Shining Path: The World's Deadliest Revolutionary Force. London: Harper Collins Publishers, 1992.

Teeple, Gary. Globalization and the Decline of Social Reform. Toronto: Garamond Press, 1995.

Teivainen, Teivo. Enter Economism: Exit Politics, Expents, Economic Policy and the Damage to Democracy. London: Zed Books, 2002.

Thorp, Rosemary and Geoffrey Bertram. Peru 1890-1977 Growth and Policy in an Open Economy. London, Macmillan Press, 1978. 
Timmerman, Jacopo. Prisoner Without A Name, Cell Without a Number. London: Weidenfield \& Nicholson, 1981.

Trimberger, Ellen K. Revolution From Above: Military Bureaucrats and Development in Japan, Turkey, Egypt, and Peru. New Brunswick, New Jersey: Transaction Books, 1978.

Tomlinson, Jim. Hayek and the Market. London: Pluto Perspectives, 1990. Ugarteche, Oscar. The False Dilemma Globalization: Opportunity or Threat. London: Zed Books, 2000.

Valdés, Juan Gabriel. Pinochet's Economists: The Chicago School In Chile. Cambridge : Cambridge University Press, 1995.

Valenzuela, Arturo. The Breakdown of Democratic Regimes: Chile. Baltimore: The John Hopkins University Press, 1987.

Valenzuela, J. and A. Valenzuela, eds. Military Rule in Chile. Baltimore: John Hopkins University Press, 1986.

Vargas Llosa, Alvaro. The Madness of Things Peruvian: Democracy under Siege. New Brunswick: Transaction Publishers, 1994.

Vargas Llosa, Mario. Death in the Andes, tr. Edith Grossman. New York: Farrar, Straus and Giroux, 1996.

Vargas Llosa, Mario. A Fish out of Water, tr. Helen Lane. Toronto: Penguin Books, 1995.

Veblen, Thorstein. The Theory of the Leisure Class: An Economic Study of Institutions. London: George Allen \& Unwin Ltd., 1957.

Waligorski, Conrad P.The Political Theory of Conservative Economists. Lawrence, Kansas: University Press of Kansas, 1990.

Wallerstein, Immanuel. Geopolitics and Geoculture: Essays on the Changing World Systems. Cambridge: Cambridge University Press, 1991.

Wallerstein, Immanuel. The Modern World-System: Capitalist Agricultture and the Origins of the European World-Economy in the Sixeenth Century. New York : Academic Press, 1976.

Weber, Max. From Max Weber: Essays in Sociology, tr. H.H. Gerth and C. Wright Mills. London : Routledge \& Kegan Paul, 1964.

Weber, Max. From Max Weber: Essays in Sociology, tr. H.H. Gerth and C. Wright Mills. London : Routledge \& Kegan Paul, 1964.

Weiner, Myron and Samuel Huntingdon, eds. Understanding Political Development. Boston: Little Brown, 1987. 
Werlich, David P. Peru: A Short History. Carbondale, Illinois: Southern Illinois University Press, 1978.

Wesson, Robert, ed. The Latin American Military Institution. New York : Praeger, 1986.

Whelan, James R. Allende: Death of a Marxist Dream. Westport, Connecticut: Arlington House Publishers, 1981.

Wiarda, Howard J. The Democratic Revolution in Latin America: History, Politics, and U.S. Policy. New York: Holmes \& Meier, 1990.

Wise, Carol. Reinventing the State: Economic Strategy and Institutional Change in Peru. Ann Arbour: The University of Michigan Press, 2003.

Wise, Carol and Riordan Roett, eds. Post Stabilization Politics in Latin America: Competition, Transition, Collapse. Washington D.C.: Brookings Institute, 2003.

Wilbur, Charles. The Political Economy of Development and Underdevelopment. New York: Random House, 1988.

Zeitlin, Maurice and Richard Earl Ratcliff. Landlords \& Capitalists: The Dominant Class of Chile. Princeton: Princeton University Press, 1988.

\section{Articles and Chapters in Books}

Abugattas, Luis. "Stabilization, Structural Reform and Industrial Reform." In Fujimori's Peru: The Political Economy, ed. John Crabtree and Jim Thomas. London: Institute of Latin American Studies, 1998.

Aguero, Felipe. "Conflicting Assessments of Democratization: Exploring the Fault Lines." In Fault Lines of Democracy in Post-transition Latin America, ed. Felipe Aguero and Jeffrey Stark. Miami: North-South Center Press, 1998.

Allen, John. "Fordism and Modern Industry." In Political and Economic Forms of Modernity, ed. John Allen, Peter Braham, and Paul Lewis. London: Polity Press, 1992.

Alvarez, Elena H. and Cervantes, Francisco Joel. "The Economic Consequences of the 'Peruvian Disease."' In The Peruvian Economy and Structural Adjustment: Past, Present, and Future, ed. Efraín Gonzales de Olarte. Coral Gables, Florida: North-South Centre Press, University of Miami, 1996.

Alvarez, Elena H. "Economic Effects of the Illicit Drug Sector." In Fujimori's Peru: 
The Political Economy, ed. John Crabtree and Jim Thomas. London: Institute of Latin American Studies, 1998.

Alvarez, Sonia E. "Politicizing Gender and Engendering Democracy." In Democratizing Brazil, ed. Alfred Stepan. New York: Oxford University Press, 1989.

Aman, Kenneth. "Conclusion: Toward a Theory of Popular Culture--Some Chilean Excursions." In Popular Culture in Chile: Resistance and Survival, ed. Kenneth Aman and Cristián Parker. Boulder, Colorado: Westview Press, 1991.

Aman, Kenneth. "Introduction: Placing Chile's Popular Culture in Context." In Popular Culture in Chile: Resistance and Survival, ed. Kenneth Aman and Cristián Parker. Boulder, Colorado: Westview Press, 1991.

Andrew, Edward. "George Grant on Technological Imperatives." In Democratic Theory and Technological Society, ed. Richard B. Dry et al. Armonk, New York: Sharpe, 1988.

Arce, Moisés. "The Sustainability of Economic Reform in a Most Likely Case." Comparative Politics (April 2003), 335-354.

Atwood, Roger. "Democratic Dictators: Authoritarian Politics in Peru from Leguia to Fujimori." SAIS Review 21, no.2 (2001), 155-176.

Bacchus, Wilfred A. "Controlled Political Transition in Brazil: Abertura as a Process for a Gradual Sharing of Political Power." In Liberalization and Redemocratization in Latin America, ed. Lopez and Stohl. New York: Greenwood Press, 1987.

Bacha, Edmar L. and Pedro S. Malan. "Brazil's Debt: From the Miracle to the Fund." In Democratizing Brazil, ed. Alfred Stepan. New York: Oxford University Press, 1989.

Balbi, Carmen Rosa. "Politics and Trade Unions in Peru." In The Peruvian Labyrinth: Polity, Society, Economy, ed. Maxwell A. Cameron and Philip Mauceri. University Park, Pennsylvania: The Pennsylvania State University Press, 1997.

Baloyra, Enrique A. "Conclusion: Toward a Framework for the Study of Democratic Consolidation." In Comparing New Democracies: Transition and Consolidation in Mediterranean Europe and the Southern Cone, ed. Enrique A. Baloyra. Boulder, Colorado: Westview Press, 1987.

Baloyra, Enrique A. "Democratic Transition in Comparative Perspective." In Comparing New Democracies: Transition and Consolidation in Mediterranean Europe and the Southern Cone, ed. Enrique A. Baloyra. Boulder, Colorado: Westview Press, 1987. 
Bangura, Yusuf. "Authoritarian Rule and Democracy in Africa: A Theoretical Discourse." In Adjustment, Authoritarianism and Democracy: An Introduction to Some Conceptual and Empirical Issues, ed. Peter Gibbon, Yusuf Bangura and Arve Ofstad. Uppsala: Scandanavian Institute of African Studies, 1992.

Baran, Paul A. "On the Political Economy of Backwardness." In The Political Economy of Development and Underdevelopment, Fourth Edition, ed. Charles K. Wilber. New York: Random House Business Division, 1988.

Baud, Michiel. "The Quest for Modernity: Latin American Technocratic Ideas in Historic Perspective." In The Politics of Expertise In Latin America, ed. Miguel A. Centeno and Silva Patricio. New York: St. Martin's Press, 1998.

Becker, David G. "Citizenship, equality, and urban property rights in Latin America: The Peruvian Case." Studies in Comparative International Development 31, no. 1 (Spring 1996), 1-26.

Beckman, Bjorn. "Empowerment of Repression: The World Bank and the Policy of Readjustment." In Adjustment, Authoritarianism and Democracy: An Introduction to Some Conceptual and Empirical Issues, ed. Peter Gibbon, Yusuf Bangura and Arve Ofstad. Uppsala: Scandanavian Institute of African Studies, 1992.

Belaúnde, Javier de. "Justice, Legality and Judicial Reform." In Fujimori's Peru: The Political Economy, ed. John Crabtree and Jim Thomas. London: Institute of Latin American Studies, 1998.

Bienefeld Manfred A. "Structural Adjustment and the Prospects for Democracy in Southern Africa." In Debating Development Discourse: Institutional and Popular Perspectives, ed. David B. Moore and Gerald J. Schmitz. New York: St. Martin's Press, 1995.

Boloña, Carlos. "The Viability of Alberto Fujimori's Economic Strategy." In The Peruvian Economy and Structural Adjustment: Past, Present, and Future, ed. Efraín Gonzales de Olarte. Coral Gables, Florida: North-South Centre Press, University of Miami, 1996.

Boron, Atilo A. "Faulty Democracies? A Reflection on the Capitalist 'Fault Lines' in Latin America." In Fault Lines of Democracy in Post-transition Latin America, ed. Felipe Aguero and Jeffrey Stark. Miami: North-South Center Press, 1998.

Bornschier, Volker. "Dependent Industrialization in the World Economy." Journal of Conflict Resolution 25, no. 3 (September 1981), 371-400.

Borzutzky, Silvia T. "The Pinochet Regime: Crisis and Consolidation." In Authoritarians and Democrats, ed. Malloy and Seligson. Pittsburgh: 
University of Pittsburgh Press, 1987.

Boylan, Delia M. "The Rise and Fall (and Rise?) of a Technopol: The Evelyn Matthei Story." In Technopols: Freeing Politics and Markets in Latin America in the 1990s, ed. Jorge I. Domínguez. University Park, Pennsylvania: The Pennsylvania State University Press, 1997.

Brenner, R. "The Origins of Capitalist Development: A Critique of neo-Smithian Marxism." New Left Review 104 (July-August 1977).

Bronstein, Arturo S. "Labour Law Reform in Latin America: Between State Protection and Flexibility." International Labour Review 136, no. 1 (Spring 1997), 5-26.

Brunner, José Joaquín. "Notes on Modernity and Postmodernity in Latin American Culture." boundary 2, 20, no. 3 (Fall 1993), 34-54.

Buci-Glucksman, Christine. "Hegemony and Consent." In Approaches to Gramsci, ed. Anne Showstack Sassoon. London: Writers and Readers, 1982.

Burns, E. Bradford. "The Modernizatiion of Underdevelopment: El Salvador, 1858-1931." In The Political Economy of Development and Underdevelopment, ed. Charles K. Wilber. New York: Random House Business Division, 1988.

Burt, Jo-Marie. "Shining Path and the Decisive Battle in Lima's Barriadas: The Case Of Villa El Salvador." In Shining and Other Paths: War and Society in Peru, 1980-1995, ed. Steve J. Stern. Durham: Duke University Press, 1998.

Bustamante, Carlos. "Democracy, Civilizational Change, and the Latin American Military." In Fault Lines of Democracy in Post-transition Latin America, ed. Felipe Aguero and Jeffrey Stark. Miami: North-South Center Press, 1998.

Cameron, Maxwell A. "Political and Economic Origins of Regime Change: The Eighteenth Brumaire of Alberto Fujimori." In The Peruvian Labyrinth: Polity, Society, Economy, ed. Maxwell A. Cameron.and Philip Mauceri. University Park, Pennsylvania: The Pennsylvania University Press, 1997.

Cameron, Maxwell A. "The Politics of the Urban Informal Sector in Peru:

Populism, Class and Redistributive Combines." Canadian Journal of Latin American and Caribbean Studies 16, no. 31 (1991), 79-104.

Cammack, Paul. "Democratization and Citizenship in Latin America." In Democracy and Democratization, ed. Perry Geraint and Michael Moran. New York: Routledge, 1994.

Cammack, Paul. "The Resurgence of Populism in Latin America." Bulletin of Latin American Research 19 (2000), 149-161. 
Canovan, Margaret. "Populism for political theorists?" Journal of Political Ideologies 9, no.3, 241-252.

Cardoso, Fernando Henrique. "Associated-Dependent Development and Democratic Theory." In Democratizing Brazil, ed. Alfred Stepan. New York: Oxford University Press, 1989.

Cardoso, Fernando Henrique. "On the Characterization of Authoritarian Regimes in Latin America." In The New Authoritarianism in Latin America, ed. David Collier. Princeton: Princeton University Press, 1979.

Carter, A. Foster. "The Modes of Production Controversy." New Left Review 107 (January-February 1978), 47-77.

Castillo Ochoa, Manuel. " Fujimori and the Business Class: A Prickly Parntership." NACLA XXX, no. 1 (July/August 1996), Report on Peru, 2530.

Cava, Ralph Della. "The 'People's Church,' the Vatican, and Abertura." In Democratizing Brazil, ed. Alfred Stepan. New York: Oxford University Press, 1989.

Cavarozzi, Marcelo. "Political Cycles in Argentina since 1955." In Transitions From Authoritarian Rule, ed. Guillermo O'Donnell et al. Baltimore: Johns Hopkins University Press, 1989.

Cavarozzi, Marcelo. "Political Cycles in Argentina since 1955." In Transitions From Authoritarian Rule, ed. Guillermo O'Donnell et al. Baltimore: Johns Hopkins University Press, 1989.

Centeno, Miguel A. "Between Rocky Democracies and Hard Markets: Dilemmas of the Double Transition." Annual Review of Sociology 20 (1994), 125147.

Centeno, Miguel A. "The Politics of Knowledge: Hayek and Technocracy." In The Politics of Expertise In Latin America, ed. Miguel A. Centeno and Patricio Silva. New York: St. Martin's Press, 1998.

Centeno, Miguel A. and Patricio Silva, eds. "The Politics of Expertise in Latin America: Introduction." In The Politics of Expertise In Latin America, ed. Miguel A. Centeno and Patricio Silva. New York: St. Martin's Press, 1998.

Chalmers, Douglas A. and Craig H. Robinson. "Why Power Contenders Choose Liberalization: Perspectives from South America." In Authoritarian and Democratic Regimes in Latin America, ed. Jorge I. Domínguez. New York: Garland Publishing, 1994.

Child, Jack. "Geopolitical Thinking." In The Military and Democracy: The Future of Civil-Military Relations in Latin America, ed. Louis W. Goodman et al. 
Lexington, Massachusetts: Lexington Books, 1990.

Chinchilla, Norma Stoltz and William Bollinger. "Theoretical Issues of the Chilean Experience." Latin American Perspectives 1, no. 2 (Summer 1974), 3-8.

Chinchilla, Norma Stoltz and Dietz, James Lowell. "Toward a New Understanding of Development and Underdevelopment." Latin American Perspectives VIII, issues 30/31, no. 3 and 4 (Summer and Fall 1981), 138-147.

Collier, David. "The Bureaucratic-Authoritarian Model: Synthesis and Priorities for Future Research." In The New Authoritarianism in Latin America, ed. David Collier. Princeton: Princeton University Press, 1979.

Collier, David. "Overview of the Bureaucratic-Authoritarian Model." In The New Authoritarianism in Latin America, ed. David Collier. Princeton: Princeton University Press, 1979.

Conaghan, Catherine M. "Reconsidering Jeffrey Sachs and the Bolivian Economic Experiment." In Money Doctors, Foreign Debts, and Economic Reforms in Latin America from the 1890s to the Present, ed. Paul W. Drake. Wilmington, Delaware: A Scholarly Resources Inc. Imprint, 1994.

Conaghan, Catherine M. "Stars of the Crisis: the Ascent of Economists in Peruvian Public Life." In The Politics of Expertise In Latin America, ed. Miguel A. Centeno and Patricio Silva. New York: St. Martin's Press, 1998.

Coral Cordero, Isabel. "Women in War: Impact and Responses." In Shining and Other Paths: War and Society in Peru, 1980-1995, ed. Steve J. Stern. Durham: Duke University Press, 1998.

Corrales, Javier. "Why Argentines Followed Cavallo: A Technopol Between Democracy and Economic Reform." In Technopols: Freeing Politics and Markets in Latin America in the 1990s, ed. Jorge I. Domínguez. University Park, Pennsylvania: The Pennsylvania State University Press, 1997.

Cortázar, René. "Austerity Under Authoritarianism: The Neoconservative Revolution in Chile." In Paying the Costs of Austerity in Latin America, ed. Howard Handelman and Werner Baer. Boulder, Colorado: Westview Press, 1989.

Correa, Marcial Rubio. "The Perception of the Subversive Threat in Peru." In The Military and Democracy: The Future of Civil-Military Relations in Latin America, ed. Louis W. Goodman et al. Lexington, Massachusetts: Lexington Books, 1990.

Cotler, Julio. "State and Regime: Comparative Notes on the Southern Cone and the 'Enclave' Societies." In The New Authoritarianism in Latin America, ed. David Collier. Princeton: Princeton University Press, 1979. 
Cotler, Julio. "Political Parties and the Problem of Democratic Consolidation in Peru." In Building Democratic Institutions: Party Systems in Latin America. Stanford: Stanford University Press, 1995.

Cox, Robert W. "Gramsci, Hegemony and International Relations, An Essay in Method." In Gramsci, Historical Materialism and International Relations, ed. Stephen Gill. Cambridge: Cambridge University Press, 1993.

Crabtree, John. "Neo-populism and the Fujimori Phenomenon." In Fujimori's Peru: The Political Economy, ed. John Crabtree and Jim Thomas. London: Institute of Latin American Studies, 1998.

Crabtree, John and Jim Thomas. "Neoliberalism, Democracy and Exclusion." In Fujimori's Peru: The Political Economy, ed. John Crabtree and Jim Thomas. London: Institute of Latin American Studies, 1998.

Crabtree, John. "Populism old and new: the Peruvian Case." Bulletin of Latin American Research 19 (2000), 163-176.

Craig, Richard B. "Illicit Drug Traffic: Implications for South American Source Countries." Journal of InterAmerican Studies 29, no.2 (1987).

Degregori, Carlos Ivan. "After the Fall of Sendero Luminoso." In The Peruvian Labyrinth: Polity, Society, Economy, ed. Maxwell A. Cameron and Philip Mauceri. University Park, Pennsylvania: The Pennsylvania State University Press, 1997.

Degregori, Carlos Ivan. "Harvesting Storms: Peasant Rondas and the Defeat of Sendero Luminoso in Ayacucho." In Shining and Other Paths: War and Society in Peru, 1980-1995, ed. Steve J. Stern. Durham: Duke University Press, 1998.

Degregori, Carlos Ivan. "Ethnicity and Democratic Governability in Latin America: Reflections from Two Central Andean Countries." In Fault Lines of Democracy in Post-transition Latin America, ed. Felipe Aguero and Jeffrey.Stark. Miami: North- South Center Press, 1998.

Degregori, Carlos Ivan, José Coronel, and Ponciano del Pinho. "Government, Citizenship and Democracy." In Fujimori's Peru: The Political Economy, ed. John Crabtree and Jim Thomas. London: Institute of Latin American Studies, 1998.

Devereux, John and Michael Connolly. "Economic Reform and the Real Exchange Rate in Peru." In The Peruvian Economy and Structural Adjustment: Past, Present, and Future, ed. Efraín Gonzales de Olarte. Coral Gables, Florida: North-South Centre Press, University of Miami, 1996. 
Diamond, Larry. "Economic Development and Democracy Reconsidered." In Reexamining Democracy, ed. Gary Marks and Larry Diamond. Newbury, California: Sage Publications, 1992.

Días, Alvaro. "New Developments in Economic and Social Restructuring in Latin America." In Politics, Social Change and Economic Restructuring in Latin America, ed. William C. Smith and Roberto Patricio Korneniewicz. Miami: North-South Centre Press, 1997.

Domínguez, Jorge I. "Technopols: Ideas and Leaders in Freeing Politics and Markets in Latin America in the 1990s." In Technopols: Freeing Politics and Markets in Latin America in the 1990s, ed. Jorge I. Domínguez. University Park, Pennsylvania: The Pennsylvania State University Press, 1997.

Donoso, Isabel. "Human Rights and Popular Organizations." In Popular Culture in Chile: Resistance and Survival, ed. Kenneth Aman and Cristián Parker. Boulder, Colorado: Westview Press, 1991.

Durand Francisco. "The Growth and Limitations of the Peruvian Right." In The Peruvian Labyrinth: Polity, Society, Economy, ed. Maxwell A. Cameron and Philip Mauceri. University Park, Pennsylvania: The Pennsylvania State University Press, 1997.

Durand, Francisco and Rosemary Thorp. "Tax Reform: The SUNAT experience." In Fujimori's Peru: The Political Economy, ed.John Crabtree and Jim Thomas. London: Institute of Latin American Studies, 1998.

Durand, Francisco. "Business and the Crisis of Peruvian Democracy." Business and Politics 4, no. 3 (2002), 319-340.

Dussel, Enrique. "Eurocentrism and Modernity, Introduction to the Frankfurt Lectures." boundary 2, 20, no. 2 (Fall 1993), 65-76.

Echeverría, Javier Iguíniz. "The Difficult Moments of the Fujimori Economic Strategy." In The Peruvian Economy and Structural Adjustment: Past, Present, and Future, ed. Efraín Gonzales de Olarte. Coral Gables, Florida: North-South Centre Press, University of Miami, 1996.

Edwards, Beatrice. "IDB Plan to Sell the Public Sector: The Cure or the III?" NACLA XXXVI, no. 3 (January/February 2003), Privatization in the Americas, 13-19.

Edwards, Sebastian. "Stabilization with Liberalization: An Evaluation of Ten Years of Chile's Experiment with Free-Market Policies, 1973-1983." Economic Development and Cultural Change 33, no. 2 (January 1985), 223-254.

Einaudi, Luigi R. "Revolution from Within? Military Rule in Peru Since 1968." In 
Authoritarian and Democratic Regimes in Latin America, ed. Jorge I. Domínguez. New York: Garland Press, 1994.

Ellner, Steve. "The Contrasting Variants of the Populism of Hugo Chávez and Alberto Fujimori." Journal of Latin American Studies 35 (2003), 139-162.

Epstein, Edward D. "Legitimacy, Institutionalization, and Opposition in Exclusionary Bureaucratic-Authoritarian Regimes: The Situation in the 1980s." Comparative Politics, (October 1984), [n.p.]

Feinberg, Richard E. "Dependency and the Defeat of Allende." Latin American Perspectives 1, no. 2 (1974), 32-43.

Figueroa, Aldolfo. "Income Distribution and Poverty in Peru." In Fujimori's Peru: The Political Economy, ed. John Crabtree and Jim Thomas. London: Institute of Latin American Studies, 1998.

Fishlow, Albert. "A Tale of Two Presidents: The Political Economy of Crisis Management." In Democratizing Brazil, ed. Alfred Stepan. New York: Oxford University Press, 1989.

Floria, Carlos Alberto. "Dilemmas of the Consolidation of Democracy in Argentina." In Comparing New Democracies, ed. Enrique A. Baloyra. Boulder, Colorado: Westview Press, 1987.

Foxley, Alejandro. "The Neoconservative Economic Experiment in Chile." In Military Rule in Chile, ed. J. Valenzuela and A. Valenzuela. Baltimore: John Hopkins University Press, 1986.

Frank, Andre Gunder. "The Development of Underdevelopment." In The Political Economy of Development and Underdevelopment, ed. Charles K. Wilber. New York: Random House Business Division, 1988.

Frank, Andre Gunder. "Latin American Development Theories Revisited: A Participant Review." Latin American Perspectives 19, issue 73, no. 2 (Spring 1992), 125-139.

Fraser, Barbara J. "Peru: Hanging Up on the Private Sector." NACLA XXXVI, no.3 (Janaury/February 2003), Privatization in the Americas, 39-42.

Frenkel, Roberto and Guillermo O'Donnell. "The 'Stabilization Programs' of the International Monetary Fund and Their Internal Impacts." In Money Doctors, Foreign Debts, and Economic Reforms in Latin America from the 1890 s to the Present, ed. Paul W. Drake. Wilmington, Delaware: A Scholarly Resources Inc. Imprint, 1994.

Fujimori, Alberto. "A Momentous Decision." In The Peru Reader: History, Culture, Politics. Durham: Duke University Press, 1995.

Fruhling, Hugo. "Judicial Reform and Democratization in Latin America." In Fault 
Lines of Democracy in Post-transition Latin America, ed. Felipe Aguero and Jeffrey Stark. Miami: North-South Center Press, 1998.

Galleguillos, Nibaldo and Jorge Nef. "Chile: Redemocratization or the Entrenchment of Counterrevolution?" In Latin America to the Year 2000: Reactivating Growth, Improving Equity, Sustaining Democracy, ed. Archibald Ritter et al. New York: Praeger, 1992.

Garcia Calderón, Ernesto. "Peru's Decade of Living Dangerously: High Anxiety in the Andes." Journal of Democracy 12, no.2 (2001), 46-58.

Garreton, Manuel Antonio M. "Military Regimes, Democracy, and Political Transition in the Southern Cone: The Chilean Case." In Liberalization and Redemocratization in Latin America, ed. George A. Lopez and Michael Stohl. New York: Greenwood Press, 1987.

Garreton, Manuel Antonio M. "The New Social Political Matrix." In Democracy in Latin America: (Re)constructing Political Society, ed. Manuel Antonio M. Garreton and Edward Newman. Tokyo: United Nations University Press, 2001.

Garreton, Manuel Antonio M. "The Political Evolution of the Chilean Military Regime and Problems in the Transition to Democracy." In Transitions From Authoritarian Rule, ed. Guillermo O'Donnell et al. Baltimore: Johns Hopkins University Press, 1989.

Garreton, Manuel Antonio M. "Social and Economic Transformations in Latin America: The Emergence of a New Political Matrix?" In Markets and Democracy in Latin America: Conflict or Convergence, ed. Philip Oxhorn and Pamela K. Starr. Boulder, Colorado: Lynne Reinner Publishers, 1999.

Geddes, Barbara. "The Politics of Economic Liberalization." LARR 30, no. 2 (1995), 195-214.

Giraldo, Jeanne Kinney. "Development and Democracy in Chile: Finance Minister Alejandro Foxley and the Concertación's Project for the 1990s." In Technopols: Freeing Politics and Markets in Latin America in the 1990s, ed. Jorge I. Domínguez. University Park, Pennsylvania: The Pennsylvania State University Press, 1997.

Gill, Stephen. "Epistemology, Ontology, and the Italian School." In Gramsci, Historical Materialism and International Relations, ed. Stephen Gill. Cambridge: Cambridge University Press, 1993.

Gill Stephen, and David Law. "Global hegemony and the structural power of capital." In Gramsci, Historical Materialism and International Relations, ed. Stephen Gill. Cambridge: Cambridge University Press, 1993. 
Goldberg, Victor P. "Toward an Expanded Economic Theory of Contract." In The Chicago School of Political Economy, ed. Warren J. Samuels. East Lansing, Michigan: Michigan State University, 1976.

Goldín, Liliana R. "Economic Restructuring and the New Forms of Market Participation in Rural Latin America." In Politics, Social Change and Economic Restructuring in Latin America, ed. William C. Smith and Roberto Patricio Korneniewicz. Miami: North-South Centre Press, 1997.

Golob, Stephanie R. "'Making Possible What Is Necessary': Pedro Aspe, the Salinas Team, and the Next Mexican 'Miracle.'" In Technopols: Freeing Politics and Markets in Latin America in the 1990s, ed. Jorge I. Domínguez. University Park, Pennsylvania: The Pennsylvania State University Press, 1997.

Goodman, Louis W. "The Military and Democracy: An Introduction." I The Military and Democracy: The Future of Civil-Military Relations in Latin America, ed. Louis W. Goodman et al. Lexington, Massachusetts: Lexington Books, 1990.

Goodman, Louis W. and Johanna S.R. Mendelson. "The Threat of New Missions: Latin American Militaries and the Drug War." In The Military and Democracy: The Future of Civil-Military Relations in Latin America, ed. Louis W. Goodman et al. Lexington, Massachusetts: Lexington Books, 1990.

Grant, George. "Ideology in Modern Empires." In Perspectives of Empire, ed. John E. Flint and Lyndwr Williams. London: Longman Group Ltd., 1973.

Grant, George. "Knowing and Making." Transactions of the Royal Society of Canada, Series IV, XII (1974).

Green, Duncan. "Latin America: Neoliberal Failure and the Search for Alternatives." Third World Quarterly 17, no. 1 (1996), 109-122.

Gülalp, Haldun. "Democracy and Underdevelopment." Studies in Political Economy, 32 (Summer 1990), 145-166.

Hagopian, Frances. "Democracy and Political Representation in Latin America in the 1990s: Pause, Reorganisation, or Decline?." In Fault Lines of Democracy in Post-transition Latin America, ed. Felipe Aguero and Jeffrey Stark. Miami: North-South Center Press, 1998.

Haworth, Nigel. "Political Transition and the Peruvian Labor Movement." In Labour Autonomy and the State, ed. Edward C. Epstein. Boston: Unwin Hyman, 1989.

Henfrey, Colin. "Dependency, Modes of Production, and the Class Analysis of Latin America." Latin American Perspectives VIII, issues 30/31, no. 3 and 
4 (Summer and Fall 1981), 17-54.

Hinojosa, Ivan. "On Poor Relations and the Nouveau Riche: Shining Path and the Radical Peruvian Left." In Shining and Other Paths: War and Society in Peru, 1980-1995, ed. Steve J. Stern. Durham: Duke University Press, 1998.

Hirschman, Albert O. "Inflation in Chile." In Money Doctors, Foreign Debts, and Economic Reforms in Latin America from the 1890s to the Present, ed. Paul W. Drake. Wilmington, Delaware: A Scholarly Resources Inc. Imprint, 1994.

Hirschman, Albert O. "The Turn to Authoritarianism in Latin America and the Search for Its Economic Determinants." In The New Authoritarianism in Latin America, ed. David Collier. Princeton: Princeton University Press, 1979, 61-98.

Hobsbawm, Eric J. "Gramsci and Marxist Political Theory." In Approaches to Gramsci, ed. Anne Showstack Sassoon. London : Writers and Readers, 1982.

Holman, Otto. "Internationalisation and Democratisation: Southern Europe, Latin America and the World Economic Crisis." In Gramsci, Historical Materialism and International Relations, ed. Stephen Gill. Cambridge: Cambridge University Press, 1993.

Hopenhayn, Martin. "Postmodernism and Neoliberalism in Latin America." boundary 2, 20, no. 3 (Fall 1993), 93-109.

Hopkins, Raul. "The Impact of Structural Adjustment on Agricultrural Performance." In Fujimori's Peru: The Political Economy, ed. John Crabtree and Jim Thomas. London: Institute of Latin American Studies, 1998.

Howe, Gary Nigel. "Dependency Theory, Imperialism, and the Production of Surplus Value on a World Scale." In Latin American Perspectives, VIII, issues 30/31, no. 3 and 4 (Summer and Fall 1981), 82-102.

Huilca Tesce, Pedro. "La Dictadura no puede resolver los problemas del Estado." Cuadernos Laborales, no. 76 (April 1992).

Huneeus, Carlos. "From Diarchy to Polyarchy: Prospects for Democracy in Chile." In Comparing New Democracies, ed. Enrique A. Baloyra. Boulder, Colorado: Westview Press, 1987.

Hunefeldt, Christine. "The Rural Landscape and Changing Political Awareness: Enterprises, Agrarian Producers, and Peasant Communities." In The Peruvian Labyrinth: Polity, Society, Economy, ed. Maxwell A. Cameron 
and Philip Mauceri. University Park, Pennsylvania: The Pennsylvania State University Press, 1997.

Hunt, Shane. "Peru: The current Economic Situation in Long-Term Perspective." In The Peruvian Economy and Structural Adjustment: Past, Present, and Future, ed. Efraín Gonzales de Olarte. Coral Gables, Florida : NorthSouth Centre Press, University of Miami, 1996.

Jellin, Elizabeth. "Emergent Citizenship or Exclusion? Social Movements and Non-Governmental Organizations in the 1990s." In Politics, Social Change and Economic Restructuring in Latin America, eds. William C. Smith and Roberto Patricio Korneniewicz. Miami: North-South Centre Press, 1997.

Kahler, Miles. "External Actors and Adjustment: The Role of the IMF." In Money Doctors, Foreign Debts, and Economic Reforms in Latin America from the 1890 s to the Present, ed. Paul W. Drake. Wilmington, Delaware: A Scholarly Resources Inc. Imprint, 1994.

Karl, Terry Lynn. "Dilemmas of Democratization in Latin America." Comparative Politics (October 1990), 1-21.

Kaufman, Robert R. "Industrial Change and Authoritarian Rule in Latin America: A concrete Review of the Bureaucratic-Authoritarian Model." In The New Authoritarianism in Latin America, ed. David Collier. Princeton: Princeton University Press, 1979.

Kay, Bruce H. "'Fujipopulism' and the Liberal State in Peru, 1990-1995." Journal of Interamerican Studies and World Affairs 38, no. 4 (Winter 1996), 55-98.

Keck, Margaret E. "The new Unionism in the Brazilian Transition." In Democratizing Brazil, ed. Alfred Stepan. New York: Oxford University Press, 1989.

Kisic, Drago. "Privatization, Investment and Sustainability." In Fujimori's Peru:

The Political Economy, ed. John Crabtree and Jim Thomas. London: Institute of Latin American Studies, 1998.

Iguiñez, Javier. "The Economic Strategy of the Fujimori Government." In Fujimori's Peru: The Political Economy, ed. John Crabtree and Jim Thomas. London: Institute of Latin American Studies, 1998.

Knight. Alan. "Populism and Neo-populism in Latin America, especially Mexico." Journal of Latin American Studies 30 (1998), 223-248.

Krischke, Paulo J. "Chile Reinvents Democracy." Latin American Research Review, 25, no. 3 (1990), 221-36.

Kurth, James R. "Industrial Change and Political Change: A European Perspective." In The New Authoritarianism in Latin America, ed. David 
Collier. Princeton: Princeton University Press, 1979.

Laclau, Ernesto. "Feudalism and Capitalism in Latin America." In Promise of Development: Theories of Change in Latin America, ed. Peter F. Klaren and Thomas J. Bossert. Boulder, Colorado: Westview Press, 1986.

Lamounier, Bolivar. "Authoritarian Brazil Revisited: The Impact of Elections on the Abertura." In Democratizing Brazil, ed. Alfred Stepan. New York: Oxford University Press, 1989.

Lechner, Norbert. "A Disenchantment Called Postmodernism." boundary 2, 20 , no. 3 (Fall 1993), 122-139.

Lechner, Norbert. "The Transformation of Politics." In Fault Lines of Democracy in Post-transition Latin America, ed. Felipe Aguero and Jeffrey Stark. Miami: North-South Center Press, 1998.

Liebhafsky, H.H. "Price Theory as Jurisprudence: Law and Economics, Chicago Style." In The Chicago School of Political Economy, ed. Warren J. Samuels. East Lansing, Michigan : Michigan State University, 1976.

Linz, Juan J. "Change and Continuity in the Nature of Contemporary Democracies." In Reexamining Democracy, ed. Gary Marks and Larry Diamond. Newbury, California: Sage Publications, 1992.

Linz, Juan J. "Totalitarian and Authoritarian Regimes." In Macropolitical Theory, ed. Fred Greenstein and Nelson Polsby. Reading, Massachusetts: Addison Wesley Publishing Company, 1975.

Lipietz, Alain. "The post-Fordist World: Labour Relations, International Hierarchy and Global Ecology." Review of International Political Economy 4, no. 1 (Spring 1997), 1-41.

Lipietz, Alain. "The Debt problem, European Integration and the New Phase of the World Crisis." New Left Review.

Lopez, George A. and Michael Stohl. "Liberalization and Redemocratization in Latin America: The Search for Models and Meanings." In Liberalization and Redemocratization in Latin America, ed. George A. Lopez and Michael Stohl. New York: Greenwood Press, 1987.

Lopez-Pintor, Rafael. "Mass and Elite Perspectives in the Process of Transition to Democracy." In Comparing New Democracies, ed. Enrique A. Baloyra. Boulder, Colorado: Westview Press, 1987.

Loveman, Brian. "¿Mision Cumplida? Civil Military Relations and the Chilean Political Transition." Journal of InterAmerican Studies and World Affairs, 35-74. 
Loveman, Brian. "'Protected Democracies' and Military Guardianship: Political Transitions in Latin America, 1978-1993." Journal of Interamerican Studies and World Affairs 36, no.2 (Summer 1994), 105-189.

Lowenthal, Abraham F. "Armies and Politics in Latin America." In Authoritarian and Democratic Regimes in Latin America, ed. Jorge I. Domínguez. New York: Garland Publishing, 1994, 93-116.

MacDonald, Laura. "Globalizing Civil Society." Millennium 23, no. 2 (Summer 1994), 267-287.

Madrid, Raúl L. "Labouring against Neoliberalism: Unions and Patterns of Reform in Latin America." Journal of Latin American Studies 35 (2003), 55-88.

Mainwaring, Scott. "Grassroots Popular Movements and the Struggle for Democracy: Nova Iguacu." In Democratizing Brazil, ed. Alfred Stepan. New York: Oxford University Press, 1989.

Mainwaring, Scott. "Transitions to Democracy and Democratic Consolidation: Theoretical and Comparative Issues." In Issues in Democratic Consolidation, ed. Scott Mainwaring. Notre Dame, Indiana: Indiana University Press, 1992.

Manrique, Nelson. "The Two Faces of Fjimori's Rural Policy." NACLA XXX, no.1 (July/August 1996), Report on Peru, 39-43.

Manrique, Nelson. "The War for the Central Sierra." In Shining and Other Paths: War and Society in Peru, 1980-1995, ed. Steve J. Stern. Durham: Duke University Press, 1998, 193-223.

Martins, Luciano. "The 'Liberalization' of Authoritarian Rule in Brazil." In Transitions From Authoritarian Rule, ed. Guillermo O'Donnell. Baltimore: Johns Hopkins University Press, 1989.

Mauceri, Philip. "State Reform, Coalitions, and the Neoliberal Autogolpe in Peru." Latin American Research Review 30, no 1. (1995), 7-37.

Mauceri, Philip. "Return of the caudillo: autocratic democracy in Peru." Third World Quarterly 18, no. 5 (1997), 899-911.

Mauceri, Philip. "The Transition to 'Democracy' and the Failures of Institution Building." In The Peruvian Labyrinth: Polity, Society, Economy, ed. Maxwell A. Cameron and Philip Mauceri. University Park, Pennsylvania: The Pennsylvania State University Press, 1997.

Meller, Patricio. "Chile." In Latin American Adjustment: How Much Has Happened, ed. John Williamson. Washington, D.C. : Institute or 
International Economics, 1990.

Mishan, Ezra J. "The Folklore of the Market: An Inquiry into the Economic Doctrines of the Chicago School." In The Chicago School of Political Economy, ed. Warren J. Samuels. East Lansing, Michigan: Michigan State University, 1976.

Moore, David B. "Development Discourse as Hegemony: Towards an Ideological History, 1945-1995." In Debating Development Discourse: Institutional and Popular Perspectives, ed. David B. Moore and Gerald J. Schmitz. New York: St. Martin's Press, 1995.

Morlino, Leonardo. "Democratic Establishments: A Dimensional Analysis." In Comparing New Democracies, ed. Enrique A. Baloyra. Boulder, Colorado: Westview Press, 1987.

Moulián, Tomás. "Political Movements and Popular Culture." In Popular Culture in Chile: Resistance and Survival, ed. Kenneth Aman and Cristián Parker. Boulder, Colorado : Westview Press, 1991.

Munck, Gerardo L. "Democratic Stability and Its Limits: An Analysis of Chile's 1993 Elections." Journal of InterAmerican Studies and World Affairs 36, no. 2 (Summer 1994), 1-38.

Munck, Ronaldo. "Imperialism and Dependency: Recent Debates and Old DeadEnds." Latin American Perspectives, VIII, issues 30/31, no. 3 and 4 (Summer and Fall 1981), 162-179.

Nef, Jorge. "The Politics of Repression: The Social Pathology of the Chilean Military." Latin American Perspectives 1, no.2 (Summer 1974), 58-77.

Nef, Jorge. "The Receiver State: Normalization and Structural Adjustment in Latin America." Unpublished paper. Presented at a conference sponsored by the Department of Spanish and Latin American Studies, Halpern Centre, Simon Fraser University, Burnaby, British Columbia, June 20th, 1990.

Nef, Jorge and Remonda Bensaabit. "'Governability' and the Receiver State in Latin America." In Latin America to the Year 2000: Reactivating Growth, Improving Equity, Sustaining Democracy, ed. Archibald M. Ritter, David Pollock and Maxwell Cameron. London: Praegar, 1992.

Norton, Robert E. "Jeff Sachs--Doctor Debt." In Money Doctors, Foreign Debts, and Economic Reforms in Latin America from the 1890s to the Present, ed. Paul W. Drake. Wilmington, Delaware: A Scholarly Resources Inc. Imprint, 1994.

Obando, Enrique. "Civil Military Relations in Peru, 1980-1996: How to Control 
and Coopt the Military (and the Consequences of Doing So)." In Shining and Other Paths: War and Society in Peru, 1980-1995, ed. Steve J. Stern Steve. Durham: Duke University Press, 1998.

Obando, Enrique. "Fujimori and The Military." In Fujimori's Peru: The Political Economy, ed. John Crabtree and Jim Thomas. London: Institute of Latin American Studies, 1998. See also "Fujimori and the Military: A Marriage of Convenience." NACLA XXX, no. 1 (July/August 1996), Report on Peru, 31-36.

O'Brien, Philip. "Authoritarianism and the New Orthodoxy: The Political Economy of the Chilean Regime, 1973-1982." In Generals in Retreat: The Crisis of Militry Rule in Latin America, ed. Philip O'Brien and Paul Cammack. Manchester: Manchester University Press, 1985.

O'Donnell, Guillermo. "Bureaucratic Authoritarianism: Argentina, 1966-1973." In Comparative Perspective, tr. James McGuire and Rae Floryr. Berkeley: University of California Press, 1988.

O'Donnell, Guillermo. "Introduction to the Latin American Cases." In Transition From Authoritarian Rule, ed. Guillermo O'Donnell et al. Baltimore: Johns Hopkins University Press, 1989.

O'Donnell, Guillermo. "Tensions in the Bureaucratic-Authoritarian State and the Question of Democracy." In The New Authoritarianism in Latin America, ed. David Collier. Princeton: Princeton University Press, 1979.

O'Donnell, Guillermo. "Transitions, Continuities, and Paradoxes." In Issues in Democratic Consolidation, ed. Scott Mainwaring et al. Notre Dame, Indiana: Indiana University Press, 1992.

O'Donnell, Guillermo. "Reflections on Contemporary South American Democracies." Journal of Latin American Studies 33 (2001), 599-609.

Oliart, Patricia. "Albert Fujimori: 'The Man Peru Needed?"' In Shining and Other Paths: War and Society in Peru, 1980-1995, ed. Steve J. Stern. Durham: Duke University Press, 1998.

Oxhorn, Philip. "Is the Century of Corporatism Over? Neoliberalism and the Rise of Neopluralism." In What kind of Market, What Kind of Democracy, Latin America in the Age of Neoliberalism, ed. Philip Oxhorn and Graciela Ducatenzeiler. University Park Pennsylvania: Penn State Press, 1999, chapter 9.

Oxhorn, Philip and Graciela Ducatenzeiler. "The Problematic Relationship between Economic and Political Liberalization: Some Theoretical Considerations." In Markets and Democracy in Latin America: Conflict or Convergence, ed. Philip Oxhorn and Pamela K. Starr. Boulder: Lynne 
Reinner Publishers, 1999.

Packenham, Robert A. "Capitalist Dependency and Socialist Dependency: The Case of Cuba." Journal of InterAmerican Studies and World Affairs (Spring 1986), 59-92.

Palma, Gabriel. "Dependency: A Formal Theory of Underdevelopment or a Methodology for the Analysis of Concrete Situations of Underdevelopment?." World Development 6, no. 7/8, 881-924.

Pereira, Luiz Carlos Bresser. "Economic Reforms and Economic Growth: Efficiency and Politics in Latin America." In Economic Reforms in New Democracies, ed. Luiz Carlos Bresser Pereira et al. Cambridge: Cambridge University Press, 1993.

Perelli, Carina. "The Military's Perception of Threat in the Southern Cone of South America." In The Military and Democracy: The Future of CivilMilitary Relations in Latin America, ed. Louis W. Goodman et al. Lexington, Massachusetts: Lexington Books, 1990.

Petras, James and Fernando Ignacio Leiva. "Chile: The Authoritarian Transition to Electoral Politics. A Critique." Latin American Perspectives 15, issue 58, no. 3 (Summer 1988), 97-114.

Petras, James. "Dependency and World System Theory: A Critique and New Directions." Latin American Perspectives VIII, issues $30 / 31$, no. 3 and 4 (Summer and Fall 1981), 148-155.

Pinho, H. Ponciano, del. "Family, culture, and 'Revolution': Everyday Life with Sendero Luminoso." In Shining and Other Paths: War and Society in Peru, 1980-1995, ed. Steve J. Stern. Durham: Duke University Press, 1998.

Pion-Berlin, David. "Military Breakdown and Redemocratization in Argentina." In Liberalization and Redemocratization in Latin America, ed. George A. Lopez and Michael Stohl. New York: Greenwood Press, 1987.

Pinzás, Teobaldo. "The Political Conditions, Economic Results, and the Sustainability of the Reform Process in Peru." In The Peruvian Economy and Structural Adjustment: Past, Present, and Future, ed. Efraín Gonzales de Olarte. Coral Gables, Florida: North-South Centre Press, University of Miami, 1996.

Przeworski, Adam. "The Games of Transition." In Issues in Democratic Consolidation, ed. Scott Mainwaring et al. Notre Dame, Indiana: Indiana University Press, 1992.

Przeworski, Adam and Fernando Limongi. "Political Regimes and Economic 
Growth." In Democracy and Development: Proceedings of IEA Conference held in Barcelona, Spain, ed. Amiya Kumar Bagchi. IEA Conference 113, 3-24, plus "Comment" by Salvador Giner.

Quijano, Aníbal. "Modernity, Identity, and Utopia in Latin America." boundary 2, 20, no. 3 (Fall 1993), 140-155.

Ratcliff, Richard E. "Capitalists in Crisis: The Chilean Upper Class and the September 11 Coup." Latin American Perspectives 1, no. 2 (Summer 1974), 78-91.

Remmer, Karen L. "Political Demobilization in Chile, 1973-1978." Comparative Politics (April 1980), 275-301.

Remmer Karen L. "The Politics of Economic Stabilization: IMF Standby programs in Latin America, 1954-1984." Comparative Politics (October 1986), 1-24.

Remmer, Karen L. and Gilbert W. Merkx. "Bureaucratic-Authoritarianism Revisted." In Authoritarian and Democratic Regimes in Latin America, ed. Jorge I. Domínguez. New York: Garland Books, 1994.

Remmer, Karen L. "The Politics of Economic Stabilization: IMF Standby Programs in Latin America, 1954-1984." In Money Doctors, Foreign Debts, and Economic Reforms in Latin America from the 1890s to the Present, ed. Paul W. Drake. Wilmington, Delaware: A Scholarly Resources Inc. Imprint, 1994.

Remmer, Karen L. "The Politics of Neoliberal Economic Reform in South America, 1980-1994." Studies in Comparative International Development Vol. 33 No. 2. (Summer 1998), 3-27.

Remmer, Karen L. "Elections and Economics in Contemporary Latin America." In Post Stabilization Politics in Latin America: Competition, Transition, Collapse, ed. Carol Wise Carol and Riordan Roett. Washington D.C.: Brookings Institute, 2003.

Renique, Jose Luis. "Apogee and Crisis of a 'Third Path': Mariateguismo, 'People's War', and Counterinsurgency in Puno, 1987-1994." In Shining and Other Paths: War and Society in Peru, 1980-1995, ed. Steve J. Stern. Durham, Duke University Press, 1998.

Rensselauer, Lee (III). "The Dimensions of the South American Cocaine Industry." Journal of InterAmerican Studies 30, No. 2-3 (Summer/Fall 1988).

Resende-Santos, João. "Fernando Henrique Cardoso: Social and Institutional Rebuilding in Brazil." In Technopols: Freeing Politics and Markets in Latin America in the 1990s, ed. Jorge I. Domínguez. University Park, 
Pennsylvania: The Pennsylvania State University Press, 1997.

Reyna Izaguirre, Carlos. "Shining Path in the $21^{\text {st }}$ Century: Actors in Search of New Script." NACLA XXX, no. 1 (July/August 1996), Report on Peru, 3738.

Rial, Juan. "The Armed Forces and Democracy: The Interests of Latin American Military Corporations in Sustaining Democratic Regimes." In The Military and Democracy: The Future of Civil-Military Relations in Latin America, ed. Louis W. Goodman et al. Lexington, Massachusetts: Lexington Books, 1990.

Rial, Juan. "The Armed Forces and the Question of Democracy in Latin America." In The Military and Democracy: The Future of Civil-Military Relations in Latin America, ed. Louis W. Goodman et al. Lexington, Massachusetts: Lexington Books, 1990.

Rial, Juan. "Political Parties and Elections in the Process of Transition in Uruguay." In Comparing New Democracies, ed. Enrique A. Baloyra. Boulder, Colorado: Westview Press, 1987.

Ritter, A.R.M. "Development Strategy and Structural Adjustment in Chile: From the Unidad Popular to the Concertación, 1970-92." Paper. Ottawa: The North-South Institute/L'Institut Nord-Sud, 1992.

Roberts, Kenneth M. "Economic Crisis and the Demise of the Legal Left in Peru." Comparative Politics (October 1992), 69-92.

Roberts, Kenneth M. "Neo-liberalism and the Transformation of Populism in Latin America: The Peruvian Case." World Politics 48, no.1 (1996), 82-116.

Roberts, Kenneth M. and Mark Peceny. "Human Rights and the United States Policy towards Peru." In The Peruvian Labyrinth: Polity, Society, Economy, ed. Maxwell A. Cameron and Philip Mauceri. University Park, Pennsylvania: The Pennsylvania State University Press, 1997.

Roca, Santiago. "Alternative Scenarios for the Peruvian Economy." In The Peruvian Economy and Structural Adjustment: Past, Present, and Future, ed. Efraín Gonzales de Olarte. Coral Gables, Florida: North-South Centre Press, University of Miami, 1996.

Rochabrún, Guillermo. "Deciphering the Enigmas of Alberto Fujimori." NACLA XXX, no. 1 (July/August 1996), Report on Peru, 16-24.

Rodriguez, Cecilia. "Weighing the Costs of a Cocaine Truce." The Globe \& Mail. 28 February 1991, A21.

Roelfse-Campbell, Zélia. The Fight against Poverty in Peru." In Peru: Beyond the Reforms. Lima: Promperú, 1997. 
Roemer, John E. "On the Relationship between Economic Development and Political Theory." In Democracy and Development: Proceedings of the IEA Conference held in Barcelona, Spain, ed. Amiya Kumar Bagchi. IEA Conference 113, 28-55, plus "Comment" by Salvador Barberà.

Roxborough, lan. "Citizenship and Social Movements under Neoliberalism." In Politics, Social Change and Economic Restructuring in Latin America, ed. William C. Smith and Roberto Patricio Korneniewicz. Miami: North-South Centre Press, 1997.

Ruccio, David F. and Lawrence H. Simon. "Radical Theories of Development: Frank, the Modes of Production School, and Amin." In The Political Economy of Development and Underdevelopment, Fourth Edition, ed. Charles K. Wilber. New York: Random House.

Ruiz Tagle Jaimez. "Trade Unionism and the State Under the Chilean Military Regime." In Labour Autonomy and the State, ed. Edward C. Epstein. Boston: Unwin Hyman, 1989.

Sagasti, Francisco. "El Poder Exterior." In El Poder in el Peru, ed. Augusto Alvarez Rodrich. Lima: Apoyo, 1993.

Salazar, Gabriel. "The History of Popular Culture in Chile: Different Paths." In Popular Culture in Chile: Resistance and Survival, ed. Kenneth Aman and Cristián Parker. Boulder, Colorado: Westview Press, 1991.

Samuels, Warren J. "The Chicago School of Political Economy: A Constructive Critique." In The Chicago School of Political Economy, ed. Warren J. Samuels. East Lansing, Michigan: Michigan State University, 1976.

Samuels, Warren J. "Toward an Expanded Economic Theory of Contract." In The Chicago School of Political Economy, ed. Warren J. Samuels. East Lansing, Michigan: Michigan State University, 1976.

Sarlo, Beatriz. "Aesthetics and Post-Politics: From Fujimori to the Gulf War." boundary 2, 20, no. 3 (Fall 1993), 180-193.

Sassoon, Anne Showstack. "Hegemony, War of Position and Political Intervention." In Approaches to Gramsci, ed. Anne Showstack Sassoon. London: Writers and Readers, 1982.

Sasson, Anne Showstack. "Passive Revolution and the Politics of Reform." In Approaches to Gramsci, ed. Anne Showstack Sassoon. London: Writers and Readers, 1982.

Saul, John S. "'For Fear of Being Condemned as Old Fashioned': Liberal Democracy vs. Popular Democracy in Sub-Saharan Africa." Review of African Political Economy 341-352. 
Schamis, Hector E. "Reconceptualizing Latin American Authoritarianism in the 1970s: From Bureaucratic-Authoritarianism to Neoconservatism." In Authoritarian and Democratic Regimes in Latin America, ed. Jorge I. Domínguez. New York: Garland Publishing, 1994, 373-392. This article also appeared in Comparative Politics 23, no. 2, 201-220.

Schmidt, Gregory D. "Delegative Democracy in Peru? Fujimori's 1995 Landslide and the Prospects for 2000." Journal of Interamerican Studies and World Affairs 42, no.1 (Spring 2000), 99-132.

Schmitz, Gerald J. "Democratizing and Demystification: Deconstructing 'Governance' as Development Paradigm." In Debating Development Discourse: Institutional and Popular Perspectives, ed. David B. Moore and Gerald J. Schmitz. New York: St. Martin's Press, 1995.

Schneider, Ben Ross. "The Material Bases of Technocracy: Investor Confidence and Neoliberalism in Latin America." In The Politics of Expertise In Latin America, ed. Miguel A. Centeno and Patricio Silva Patricio. New York: St. Martin's Press, 1998.

Schydlowsky, Daniel M. "The Peruvian Economy circa 1990: Structure and Consequences." In The Peruvian Economy and Structural Adjustment: Past, Present, and Future, ed. Efraín Gonzales de Olarte. Coral Gables, Florida: North-South Centre Press, University of Miami, 1996.

Seligman Linda. "To Be in Between: The Cholas as Market Women." In Constructing Culture and Power, ed. Daniel Levine. Ann Arbour, Michigan: The University of Michigan Press, 1993.

Seligman, Linda. "Survival Politics and the Movements Of Market Women in Peru in the Age of Neoliberalism." In The Third Wave of Modernization in Latin America: Cultural Perspectives on Neoliberalism, ed. Lynn Phillips. Wilmington: Jaguar Books, 1998.

Seligson, Mitchell A. "Democratization in Latin America: The Current Cycle." In Authoritarians and Democrats, ed. James M. Malloy and Mitchell A. Seligson. Pittsburgh: University of Pittsburgh Press, 1987.

Serra, José. "Three Mistaken Theses Regarding the Connection between Industrialization and Authoritarian Regimes." In The New Authoritarianism in Latin America, ed. David Collier. Princeton: Princeton University Press, 1979.

Sigmund, Paul. "[review, n.d]." Comparative Politics (October 1993), 111-122.

Silva, Eduardo. "The Business-State Nexus in Chile's Economic Transformation, 1975-1994." Comparative Politics (1995-96), 299-320. 
Silva, Patricio. "Technocrats and Politics in Chile: From the Chicago Boys to the CIEPLAN Monks." Journal of Latin American Studies 23, no. 2 (May 1991), 385-410.

Skidmore, Thomas E. "Brazil's slow Road to Democratization: 1974-1985." In Democratizing Brazil, ed. Alfred Stepan. New York: Oxford University Press, 1989.

Smith, William C. "The Political Transition in Brazil: From Authoritarian Liberalization and Elite Conciliation to Democratization." In Comparing New Democracies, ed. Enrique A. Baloyra. Boulder, Colorado: Westview Press, 1987.

Smith, William C. "State, Market and Neoliberalism in Post-Transition Argentina: The Menem Experiment." Journal of Interamerican Studies and World Affairs 33, no. 4 (Winter 1991), 111-132.

Smith, William C. "Neoliberal Restructuring and Scenarios of Democratic Consolidation in Latin America." Studies in International Comparative Development 28, no. 2 (Summer 1993), 3-21.

Smith, William C. and Roberto Patricio Korneniewicz. "Latin America and the Second Great Transformation." In Politics, Social Change and Economic Restructuring in Latin America, ed. William C. Smith, and Roberto Patricio Korneniewicz. Miami: North-South Centre Press, 1997.

Sonntag, Heinz R. "Crisis and Regression: Ecuador, Paraguay, Peru and Venezuela." In Democracy in Latin America: (Re)constructing Political Society, ed. Manuel Antonio M. Garreton, and Edward Newman. Tokyo: United Nations University Press, 2001.

Souza, Maria do Carmo Campello de. "The Brazilian 'New Republic': Under the 'Sword of Damocles.'" In Democratizing Brazil, ed. Alfred Stepan. New York: Oxford University Press, 1989.

Stark, Jeffrey. "Globalization and Democracy in Latin America." In Fault Lines of Democracy in Post-transition Latin America, ed. Felipe Aguero and Jeffrey Stark. Miami: North-South Center Press, 1998.

Starn, Orin. "Nightwatch." In The Peru Reader: History, Culture, Politics, ed. Orin Starn, Carlos Ivan Degregori, and Robin Kirk. Durham and London: Duke University Press, 1995.

Starn Orin. "Villagers at Arms: War and the Counterrevolution in the Central South Andes" In Shining and Other Paths: War and Society in Peru, 19801995, ed. Steve J. Stern. Durham: Duke University Press, 1998.

Stavenhagen, Rodolfo. "Social Dimensions: Ethnicity." In Democracy in Latin 
America: (Re)constructing Political Society, ed. Manuel Antonio M. Garreton and Edward Newman. Tokyo: United Nations University Press, 2001.

Stavrakakis, Yannis. "Antinomies of Formalism: Laclau's Theory of Populism and the Lessons from Religious Populism in Greece." Journal of Political Ideologies 9, no. 3 (October 2004), 253-267.

Steenland, Kyle. "The Coup in Chile." In Latin American Perspectives 1, no. 2 (Summer 1974), 9-20.

Stern, Steve J. "Beyond Enigma: An Agenda for Interpreting Shing Path and Peru." In Shining and Other Paths: War and Society in Peru, 1980-1995, ed. Stever J. Stern. Durham: Duke University Press, 1998.

Stern, Steve J. "Shining and Other Paths: The Origins, Dynamics, and Legacies of War, 1980-1995." In Shining and Other Paths: War and Society in Peru, 1980-1995, ed. Steve J. Stern. Durham: Duke University Press, 1998, 470-476.

Stokes, Susan C. "Democratic Accountability and Policy Change Economic Policy in Fujimori's Peru." Comparative Politics (January 1997), 209-225.

Strassmann, W. Paul. "Development Economics from a Chicago Perspective." In The Chicago School of Political Economy, ed. Warren J. Samuels. East Lansing, Michigan: Michigan State University, 1976.

Suarez, Waldino. "Argentina: Political Transition and Institutional Weakness in Comparative Perspective." In Comparing New Democracies, ed. Enrique A. Baloyra. Boulder, Colorado: Westview Press, 1987.

Szusterman, Celia. "Carlos Saúl Menem: variations on the theme of populism." Bulletin of Latin American Research 19 (2000), 193-206.

Tanaka, Martin. "From Movimientismo to Media Politics: The Changing Boundaries between Society and Politics in Fujimori's Peru." In Fujimori's Peru: The Political Economy, ed. John Crabtree and Jim Thomas. London: Institute of Latin American Studies, 1998.

Tanaka, Martin. "The Political Constraints on Market Reform in Peru." In Post Stabilization Politics in Latin America: Competition, Transition, Collapse, ed. Carol Wise and Riordan Roett. Washington D.C.: Brookings Institute, 2003.

Thorp, Rosemary. "A Long-Run Perspective on Short-run Stabilization: The Experience of Peru." In The Peruvian Economy and Structural Adjustment: Past, Present, and Future, ed. Efraín Gonzales de Olarte. Coral Gables, Florida: North-South Centre Press, University of Miami, 1996. 
Thoumi, S. "Some implications of the Growth of the Underground Economy in Colombia." Journal of InterAmerican Studies 29, no. 2.

Torre, Juan Carlos. "The Politics of Transformation in Historical Perspective." In Politics, Social Change and Economic Restructuring in Latin America, ed. William C. Smith and Roberto Patricio Korneniewicz. Miami: North-South Centre Press, 1997.

Vacs, Aldo C. "Authoritarian Breakdown and Redemocratization in Argentina." In Authoritarians and Democrats, ed. James M. Malloy and Mitchell A. Seligson. Pittsburgh: University of Pittsburgh Press, 1987.

Valenzuela, Arturo. "Chile: Origins, Consolidation and Breakdown of a Democratic Regime." In Developing Countries, Volume Four, ed. Larry Diamond et al. Boulder, Colorado: Lynne Reimer Publishers, 1984.

Valenzuela, J. Samuel. "Democratic Consolidation in Post-Transitional Settings: Notion, Process, and Facilitating Conditions." In Issues in Democratic Consolidation, ed. Scott Mainwaring et al. Notre Dame, Indiana: Indiana University Press, 1992.

Vallejo, Alejandra. "The reform of the State in Peru: The Privatization Program." In Peru: Beyond the Reforms. Lima: Promperú, 1997.

van Dijck, Pitou. "The World Bank and the Transformation of Latin American Society." In The Politics of Expertise In Latin America, ed. Miguel A. Centeno and Patricio Silva. New York: St. Martin's Press, 1998.

Vandenburg, Willem G. "Political Imagination." In Democratic Theory and Technological Society," ed. Richard B. Dry et al. Armonk, New York: Sharpe, 1988.

Varas, Augusto. "Civil-Military Relations in a Democratic Framework." In The Military and Democracy: The Future of Civil-Miliary Relations in Latin America, ed. Louis W. Goodman et al. Lexington, Massachusetts: Lexington Books, 1990.

Varas, Augusto. "Democratization in Latin America: A Citizen Responsibility." In Fault Lines of Democracy in Post-transition Latin America, ed. Felipe Aguero and Jeffrey Stark. Miami: North-South Center Press, 1998.

Waisman, Carlos H. "Civil Society, State Capacity, and the Conflicting Logics of Economic and Political Change." In Markets and Democracy in Latin America: Conflict or Convergence, ed. Philip Oxhorn and Pamela K. Starr. Boulder: Lynne Reinner Publishers, 1999.

Walker, R. "Social Movements and World Politics." Millennium 23, no. 3 (1994), 669-700. 
Wallerstein, Michael. "The Collapse of Democracy in Brazil: Its Economic Determinants." In Authoritarian and Democratic Regimes in Latin America, ed. Jorge I. Domínguez. New York: Garland Publishers, 1994.

Wallerstein, Immanuel. "The Concept of National Development, 1917-1989: Elegy and Requiem." In Reexamining Democracy, ed. Gary Marks and Larry Diamond. Newbury Park, California: Sage Publications, 1992.

Wallerstein, Immanuel. "The Rise And Future Demise of the World Capitalist System: Concepts for Comparative Analysis." Comparative Studies in Society and History no.16 (January 1974).

Weber, Max. "Ideas and Religious Interests." In Theories of Society: Foundations of Modern Sociological Theory, ed. Talcott Parsons et al. New York: The Free Press, 1965).

Weber, Max. The Protestant Ethic and the Spirit of Capitalism. New York: Charles Scribner's Sons, 1958.

Weffort, Francisco. "Why Democracy?." In Democratizing Brazil, ed. Alfred Stepan. New York : Oxford University Press, 1989.

Weland, Kurt. "Neopopulism and Neoliberalism in Latin America: Unexpected Affinities." Studies in Comparative International Development 31, no. 3 (Fall 1996), 1-29.

Wise Carol. "State Policy and Social Conflict in Peru." In The Peruvian Labyrinth: Polity, Society, Economy, ed. Maxwell A. Cameron and Philip Mauceri. University Park, Pennsylvania: The Pennsylvania State University Press, 1997.

Wise, Carol. "Introduction: Latin American Politics in the Era of Market Reform." In Post Stabilization Politics in Latin America: Competition, Transition, Collapse, ed. Carol Wise and Riordan Roett. Washington D.C.: Brookings Institute, 2003.

Yashar, Deborah J. "Contesting Citizenship: Indigenous Movements and Democracy in Latin America." Comparative Politics (October 1998), 23-42.

Yashar Deborah J. "Democracy, Indigenous movements and the Postliberal Challenge in Latin America." World Politics 52, no. 1 (1999), 76-104.

Zeitlin, Maurice. The Civil Wars in Chile (or the Bourgeois Revolutions That Never Were), chapter one: "Prelude: Class, State, and Captialist Development," and chapter five: "Reprise: Class Relations, the 'World System,' and Development." Princeton: Princeton University Press, 1984. 


\section{Spanish-language Books and Articles}

Adrianzén, Alberto. "Desafios del Moviemiento Sindical frente a la Problematica de lacalidad de Vida y Condiciones Laborales de los Trabajadores." In Movimiento Sindical: Una propuesta para el mejoramiento de la calidad de vida. Lima: Plades, 1993.

Adrianzén, Alberto M. "El Plan Verde." Quehacer 107 (May-June 1997).

Alfaro Moreno, Rosa Mariá. Hacia un estado neoliberal?: Compriensiones y valoraciones de la polación sobre los cambios del Estado. Lima: A.C.S. Calandria, 1997.

Althaus, Jaime de. "El Poder de los empressarios." In El Poder en el Peru, ed. Augusto Alvarez Rodrich. Lima: Apoyo, 1993.

Alvarez Rodrich, Augusto, ed. El Poder in el Peru. Lima: Apoyo, 1993.

Alvarez Rodrich, Augusto y Gabriel Ortiz de Zevallos, eds. Implementacion de Politicas Publicas en el Peru. Lima: Apoyo, 1995.

Amat y León, Carlos. "La Aldea Andina en la Globalizacion." Cuestion de Estado 19 (October-December 1996), 78-80.

Amat y León, Carlos. "Situacion Nacional en la Ultima Decada: Desafíos del Perú en los años 90." In Movimiento Sindical: Una propuesta para el mejoramiento de la calidad de vida. Lima: Plades, 1993.

Arellano, Nebuir. "Fujimori, el illusionista." In Cuadernos Laboral 79 (July 1992).

Ausejo, Flavio. "La reforma del Instituto Peruano de Seguridad Social." In Implementacion de Politicas Publicas en el Peru, ed. Augusto Alvarez Rodrich y Gabriel Ortiz de Zevallos. Lima: Apoyo, 1995.

Balbi, Carmen Rosa. "Situacion del Movimiento Sindical Peruano." In Movimiento Sindical: Una propuesta para el mejoramiento de la calidad de vida. Lima: Plades, 1993.

Balbi, Carmen Rosa. "El desaparecido poder del sindicalismo." In El Poder in el Peru, ed. Augusto Alvarez Rodrich. Lima: Apoyo, 1993.

Balbi Scareno, Carmen Rosa. "Sindicalismo y Flexibilizacion del Mercado de Trabajo en el Peru." In Debates en Sociología 19 (1994).

Bermedo Alvarado, Jorge. "Ultimo discorso o ultimo emperador." Cuadernos Laboral 102 (July 1994).

Bemales Ballesteros, Enrique. "Del Parlamento Constitucional a la ficción parlamentaria." In El Poder in el Peru, ed. Augusto Alvarez Rodrich. Lima: Apoyo, 1993. 
Blancas Bustamante, Carlos. El Derecho de la Estabilidad en el Trabajo. Lima: ADEC-ATC, 1991.

Blondet, Cecilia. "Poder y organizaciones populares: estrategias de integración social." In El Poder in el Peru, ed. Augusto Alvarez Rodrich. Lima: Apoyo, 1993.

Burga, Manuel. "Leguía y Fujimori: época diferentes, hombres distintos y un peligroso final." Quehacer 107 (May-June 1997).

Burneo, Kurt. "Perspectivas del programma de estabilizacion de reformas estructurales implementads en el Peru 1990-1992." In Foro de Trabajo. Lima: Cedal, April, 1993.

Bustamante Belaunde, Alberto. "El poder del presidente." In El Poder in el Peru, ed. Augusto Alvarez Rodrich. Lima: Apoyo, 1993.

Campana Z., David. El Trabajo Precario en el Sector de Confecciones, Cuadernos Plades No. 3. Lima: Plades, 1994.

Caravedo, Baltazar. "El poder de los gobiernos locales." In El Poder in el Peru, ed. Augusto Alvarez Rodrich. Lima: Apoyo, 1993.

Carrión, Julio. "La Opinión Pública bajo el primer gobierno de Fujimori: de identidaes a intereses?" In Los Enigmas del poder: Fujimori 1990-1996, ed. FernandoTuesta Soldevilla. Lima: Fundación Friedrich Ebert, 1996.

Carvallo Rey, Constantino. "País de ciegos." Quehacer 107 (May-June 1997), 59-62.

Castillo, Manuel. "Un Cierta Indiferencia." Coyuntura Laboral 97 (March 1995).

Castro, Carlos and Verónica Zavala. "Reforma de administrición tributaria." In Implementacion de Politicas Publicas en el Peru, eds. Augusto Alvarez Rodrich Augusto y Gabriel Ortiz de Zevallos. Lima: Apoyo,1995.

Checa, Pablo. "Retos del Movimiento Sindical."Movimiento Sindical: Una propuesta para el mejoramiento de la calidad de vida. Lima: Plades, 1993.

Cisneros Hamann, Luis Jaime. "El poder de la prensa." In El Poder in el Peru, ed. Augusto Alvarez Rodrich. Lima: Apoyo, 1993.

Conaghan Catherine M. "Vida pública en los tiempos de Alberto Fujimori." In Los Enigmas del poder: Fujimori 1990-1996, ed. Fernando Tuesta Soldevilla. Lima: Fundación Friedrich Ebert, 1996.

[n.d.] Constitucion Politica del Peru. Promulgada el 29 de Deciembre de 1993. Published by the Government of Peru [n.d.]

Cortés, Juan Carlos. "Analisis y Comentarios al Reglamento." Coyuntura Laboral 104, (February 1996).

Cotler, Julio. "Est tendencia economica nos condena a vivir con autoritarian, violencia y anomia." Cuadernos Laboral 78 (June 1992). 
Dávilla Pérez, Pilar. "La visión de los implementadores de políticas." In Implementacion de Politicas Publicas en el Peru, ed. Augusto Alvarez Rodrich y Gabriel Ortiz de Zevallos. Lima: Apoyo, 1995.

Dietz, Henry and William E. Dugan. "Clases sociales urbanas y comportamiento electoral en Lima: un análysis de datos agregados." In Los Enigmas del poder: Fujimori 1990-1996, ed. Fernando Tuesta Soldevilla. Lima: Fundación Friedrich Ebert, 1996.

[n.a.] "El costo de Portanos bien." Cuadernos Laborales (February 1992).

Franco Perez, Julio C. "Apuntes sobre economia, sindicalismo y politica en el Peru." In Foro de Trabajo. Lima: Cedal, April, 1993.

Franco Perez, Julio C. "Neoliberalismo y flexibilizacion laboral:Diagnostico y apuntes para una estrategia alternativa." In Foro de Trabajo. Lima: Cedal, April, 1993.

Gamero, Julio and Lourdes Valverde. "Quatro Años de Neoliberalismo en el Perú." Quehacer 90 (July-August 1994).

Gamero Julio. "La Reingenería y los Sindicatos." Coyuntura Laboral, no. 105 (April 1996).

Gamero, Julio, "Sindicatos débile, pocos aumentos." Coyuntura Laboral, no. 108, (February 1997).

Garibaldi Y, Jose Alberto and Rosa Carolina Sandoval. "La negociación de la ley general de presupuesto de 1992." In Implementacion de politicas publicas en el Peru, ed. Augusto Alvarez Rodrich and Gabriel Ortiz de Zevallos. Lima: Apoyo, 1995.

Guerra Garcia, Gustavo. "Los programas de compensación social en el Perú (1990-92)." In Implementacion de politicas publicas en el Peru, ed. Augusto Alvarez Rodrich and Gabriel Ortiz de Zevallos. Lima: Apoyo, 1995.

Hernandez, Teodulo. "Hacia un sindicalismo con propuestas." Coyuntura Laboral 97 (March 1995).

Iturraspe, Francisco. "Globalizacion de Economia, Integracion de Mercados y su impacto en el Derecho de Trabajo." Assessoria Laboral 74 (February 1997).

Izaguirre, Karina. "La privatización de las telecommunicaciones." In Implementacion de Politicas Publicas en el Peru, ed. Augusto Alvarez Rodrich and Gabriel Ortiz de Zevallos. Lima: Apoyo, 1995.

Izaguirre, Karina. "La desactivación de la comisión controla dora de trabajo marítimo." In Implementacion de Politicas Publicas en el Peru, ed. Augusto Alvarez Rodrich and Gabriel Ortiz de Zevallos. Lima: Apoyo, 1995. 
Kenney, Charles. "Por qué el autogolpe?" In Los Enigmas del poder: Fujimori 1990-1996, ed. Fernando Tuesta Soldevilla. Lima: Fundación Friedrich Ebert, 1996.

Klaiber, Jeffrey [S.J]. "El poder religioso." In El Poder in el Peru, ed. Augusto Alvarez Rodrich. Lima: Apoyo, 1993.

Larco, Giovanna. "Situacion del Movimiento Sindical Textil y Confecciones." In Movimiento Sindical: Una propuesta para el mejoramiento de la calidad de vida. Lima: Plades, 1993.

Larco Drouilly, Giovanna, ed. Los Desafíos Sindicales de la Reestructuación Empresarial. Lima: Red Peruana del Trabajo Plades, 1996.

Larco Drouilly, Giovanna. "Con los Ojos bien abiertos: Reesructuración." In Los Desafíos Sindicales de la Reestructuación Empresarial, ed. Giovanna Larco Drouilly. Lima: Red Peruana del Trabajo Plades, 1996.

Lauer, Mirko. Dias Dividas: Columnas políticas de los años 90. Lima: Adec-Atc, 1994.

Lauer, Mirko. "Poder, continuidad y cambio en la technocracia peruana." In EI Poder in el Peru, ed. Augusto Alvarez Rodrich. Lima: Apoyo, 1993.

Llorca, Yves-Claude. "El termometro no tiene la culpa de la fiebre." Quehacer 107 (May-June 1997), 28-29.

López Chau, Luis. "La Urgente Necesidad de Cambio en el Movimiento Sindical." In Movimiento Sindical: Una propuesta para el mejoramiento de la calidad de vida. Lima: Plades, 1993.

[n.a.] "Mechanica Naranja." Caretas 1573 (24 June 1999).

Mendoza Arroyo, Amalia. "El Contrato de trabajo en la Ley de Fomento del Empleo." Cuadernos Laboral (February 1992).

McClintock, Cynthia. "La voluntad política presidencial y la ruptura constitutiocional de 1992 en el Peru." Los Enigmas del poder: Fujimori 1990-1996, ed. Fernando Tuesta Soldevilla. Lima: Fundación Friedrich Ebert, 1996.

Mendoza Arroyo, Amalia. "Cuestionable ante proyecto (Ley de Relaciones Collectivas de Trabajo)." Cuadernos Laboral 78 (June 1992).

Mendoza Arroyo, Amalia and Javier Rodriguez. "Una democracia a la medida de las circunstancias." Cuadernos Laboral 78 (June 1992).

Mendoza Arroyo, Amalia. "Las relaciones colectivas de trabajo del liberalismo." Cuadernos Laboral 79 (July 1992).

Mendoza Arroyo, Amalia. "Obituario para el Derecho Laboral." Cuadernos Laboral 84, (December 1992).

Monge, Carlos. "De Gremios y Partidos en el Peru."Argumentos (July, 1995). 
Mujica Petit, Javier. "Una Ley para Guerra." Cuadernos Laboral 79 (July 1992).

Neves, Javier. "Carta de Intencion al FMI: Aspectos Laborales." Coyuntura Laboral 88 (May 1994).

Neves, Javier. "Modernizando la securidad social." Quehacer 107 (May-June 1997), 62-65.

Obando, Enrique. "El poder de los militares." El Poder in el Peru, ed. Augusto Alvarez Rodrich. Lima: Apoyo, 1993.

[n.a.] "Obligaciones de los organizaciones syndicatos." Asesoria Laboral 49 (January 1995).

Palacios Lovaton, David. "El vinculo entre los nivelles negciales y autonomia colectiva en el Peru." Assessorial Laboral 28 (April 1993).

Panfichi, Aldo and Sanborn Cynthia. "Fujimori y las raíces del neopopulismo." In Los Enigmas del poder: Fujimori 1990-1996, ed. Fernando Tuesta Soldevilla. Lima: Fundación Friedrich Ebert, 1996.

Paniagua, Valentín. "Un tríptico instutional:Ios organismos electorales." In Los Enigmas del poder: Fujimori 1990-1996, ed. Fernando Tuesta Soldevilla. Lima: Fundación Friedrich Ebert, 1996.

Paniagua, Valentín. "El significado de la destución de los magistrados del TC." Quehacer 107 (May-June 1997).

Pásara, Luis. "El ocaso de los partidos." In El Poder in el Peru, ed. Augusto Alvarez Rodrich. Lima: Apoyo, 1993.

Pilar Tello, María del. "El poder de las instituciones." In El Poder in el Peru, ed. Augusto Alvarez Rodrich. Lima: Apoyo, 1993.

Planas, Pedro. "Existe un sistema de partidos en el Perú?" In Los Enigmas del poder: Fujimori 1990-1996, ed. Fernando Tuesta Soldevilla. Lima: Fundación Friedrich Ebert, 1996.

[n.a.] "Los Poder del Estado." Coyuntura Laboral 77 (January 1993).

Portugal Mendoza, Carlos. "La Reestructuración y Privatización de la Minerì a Peruana y Los Retos para el Sindicalismo." In Los Desafíos Sindicales de la Reestructuación Empresarial, ed. Giovanna Larco Drouilly. Lima: Red Peruana del Trabajo Plades, 1996.

Prelle, Herbert. "El Protagismo Del Ejecutivo." Coyuntura Laboral (February, 1995).

Prelle Herbert. "Los Sindicatos y sus atribuciones." Coyuntura Laboral no. 109 (April 1997).

Recavarren, Jorge Luis. "Las instituciones y el poder en el Perú." In El Poder in el Peru, ed. Augusto Alvarez Rodrich. Lima: Apoyo, 1993.

Reyna, Carlos. "Los temas laborales en el proximo gobierno." Coyuntura Laboral 
100 (July 1995), 24-25.

Rivero, Oswaldo de. "Inserción económica, deserción democrática." Quehacer 107, (May-June 1997).

Romaní, Humberto. "Pacto Andino." In Movimiento Sindical: Una propuesta para el mejoramiento de la calidad de vida, Cuadernos Plades No. 1. Lima: Plades, 1993.

Rubio Correa, Marcial. "El poder de los independientes." In El Poder in el Peru, ed. Augusto Alvarez Rodrich. Lima: Apoyo, 1993.

Rubio Correa, Marcial. "Hemos vivido, en el pasado y estamos llegando tarde al processo de integracion." Cuadernos Laboral 78 (June 1992).

Sagasti, Francisco. "El poder exterior." In El Poder in el Peru, ed. Augusto Alvarez Rodrich. Lima: Apoyo, 1993.

Sánchez León, Abelardo. "El intelectual: un zapatero sin zapatos." In El Poder in el Peru, ed. Augusto Alvarez Rodrich. Lima: Apoyo, 1993.

Schmidt, Gregory D. "Comportamiento electoral estratégico: la fuerza oculta en el Tsunami." In Los Enigmas del poder: Fujimori 1990-1996, ed. Fernando Tuesta Soldevilla. Lima: Fundación Friedrich Ebert, 1996.

Sepúlveda, Juan Manuel. "Sindicatos y Desarolo Productivo." In Los Desafíos Sindicales de la Reestructuación Empresarial, ed. Giovanna Larco Drouilly. Lima: Red Peruana del Trabajo Plades, 1996.

Shuldt, Jurgen. "Trasfondos ideologicos del Neoliberalismo." La Revista del Economista.

Silva, Alfredo. "Una Representacion Legitima." Cuadernos Laboral 105 (October 1994).

Stokes Susan C. "Reforma económica y Opinión Pública en el Perú, 19901995." In Los Enigmas del poder: Fujimori 1990-1996, ed. Fernando Tuesta Soldevilla. Lima: Fundación Friedrich Ebert, 1996.

Sulmont, Denis. "Apuntes sobre el estudio de Isabea Yepez:Flexibilidad y precarizacion del empleo, Desafio al Sindicalismo." Debates en Sociologia 16 (September 1991).

Sumar Gilt, Paul. "La Demanda de Justica Laboral." Cuadernos Laboral 106 (November 1994).

Tapia, Carlos. "El poder y la subversión." In El Poder in el Peru, ed. Augusto Alvarez Rodrich. Lima: Apoyo, 1993.

Tironi, Eugenio. Autoritarismo, Modernizacion y Marginalidad: el Caso de Chile 1973-1989. Santiago: SUR, 1990.

Torres, Alfredo. "Los cambios en la opinión pública." In El Poder in el Peru, ed. Augusto Alvarez Rodrich. Lima: Apoyo, 1993. 
Torres y Torres Lara, Carlos. Los Nudos del Poder: Una Experiencia peruana de gobierno. Lima: Desarrollo y Paz, 1992.

Tuesta Soldevilla, Fernando, ed. Los Enigmas del poder: Fujimori 1990-1996. Lima: Fundación Friedrich Ebert, 1996.

Teusta Soldevilla, Fernando. "El impacto del sistema electoral sobre el sistema político peruano." In Los Enigmas del poder: Fujimori 1990-1996, ed. Fernando Tuesta Soldevilla. Lima: Fundación Friedrich Ebert, 1996.

Trahtemberg, León. "La agenda de emergencia para el sector educación." Quehacer 107 (May-June 1997), 57-58.

Trazegnies Granda, Fernando de. "Los poderes pululantes." In El Poder in el Peru, ed. Augusto Alvarez Rodrich. Lima: Apoyo, 1993.

Valverde, Lourdes. "La Caída del empleo productivo."Coyuntura Laboral 109 (April 1997).

Villarán, Fernando. "Situacion del Sector Textil y Confeccion en el Contexto Industrial." In Movimiento Sindical: Una propuesta para el mejoramiento de la calidad de vida. Lima: Plades, 1993.

[n.a.] "Violencia contra los trabajores." Coyuntura Laboral 77 (January 1993).

Zegarra Méndez, Eduardo. "Libre mercado y Estado regulador: Suficientes para el desarrollo?" Quehacer 107 (May-June 1997).

\section{Peruvian Newspapers and Magazines}

Caretas

El Commercio

Expresso

Quehacer

La República

El Sol 